UNIVERSIDADE DE SÃO PAULO

FACULDADE DE MEDICINA DE RIBEIRÃO PRETO

DEPARTAMENTO DE GENÉTICA

HEMOCENTRO DE RIBEIRÃO PRETO

\title{
IDENTIFICAÇÃO DE VIAS MODULADAS POR microRNAS NA DIFERENCIAÇÃO CELULAR E MANUTENÇÃO DA PLURIPOTÊNCIA EM CÉLULAS HUMANAS
}

Ildercílio Mota de Souza Lima 
ILDERCÍLIO MOTA DE SOUZA LIMA

\section{IDENTIFICAÇÃO DE VIAS MODULADAS POR microRNAS NA DIFERENCIAÇÃO CELULAR E MANUTENÇÃO DA PLURIPOTÊNCIA EM CÉLULAS HUMANAS}

Tese de doutorado apresentada ao Programa de Pós-Graduação em Genética da Faculdade de Medicina de Ribeirão Preto da Universidade de São Paulo, como parte dos pré-requisitos para obtenção do título de Doutor em Ciências.

Área de concentração: Genética Orientador: Dr. Rodrigo Alexandre Panepucci 
AUTORIZO A DIVULGAÇÃO TOTAL OU PARCIAL DESTE TRABALHO, POR QUALQUER MEIO CONVENCIONAL OU ELETRÔNICO, PARA FINS DE ESTUDO E PESQUISA, DESDE QUE CITADA A FONTE.

Preparada pela Biblioteca Central do Campus Administrativo de Ribeirão Preto/USP.

Lima, Ildercílio Mota de Souza.

Identificação de vias moduladas por microRNAs na diferenciação celular e manutenção da pluripotência em células humanas. Ribeirão Preto, 2017.

238 p. : il.; $30 \mathrm{~cm}$

Tese de Doutorado apresentada à Faculdade de Medicina de Ribeirão Preto/USP. Área de concentração: Genética.

Orientador: Panepucci, Rodrigo Alexandre.

1. Células-Tronco. 2. Pluripotência. 3. Diferenciação Celular. 4. miRNAs.

5. High Content Analysis. 
Ildercílio Mota de Souza Lima

Identificação de vias moduladas por microRNAs na diferenciação celular e manutenção da pluripotência em células humanas.

Tese apresentada à Faculdade de Medicina de Ribeirão Preto da Universidade de São Paulo para obtenção do Título de Doutor em Ciências.

Área de Concentração: Genética

Aprovado em

\section{Banca examinadora}

Prof. Dr. Rodrigo Alexandre Panepucci

Instituição

Assinatura

Prof. Dr(a)

Instituição

Assinatura

Prof. Dr(a)

Instituição

Assinatura

Prof. Dr.

Instituição

Assinatura

Prof. Dr.

Instituição

Assinatura 
Dedico este trabalho àqueles que me permitiram chegar aqui,

Minha família, amigos e mestres. 


\section{AGRADECIMENTOS}

Essa etapa da minha vida, compreendida pelo período em que desenvolvi o doutorado, foi repleta de aprendizados que me ajudaram a crescer não somente como profissional, mas também como pessoa. As dificuldades enfrentadas foram muitas, mas acredito que isso seja comum entre muitos alunos da pós-graduação. Enfrentamos problemas que, muitas vezes, estão fora até do nosso alcance para serem resolvidos e que nos afetam de diferente formas, refletindo principalmente no tempo que temos para cumprir os prazos que nos são exigidos. Aqui eu quero dar foco não aos problemas e dificuldades enfrentados por mim, mas sim às pessoas que estiveram ao meu lado, me ajudando de forma direta ou indireta, participando assim da conclusão deste importante passo da minha formação acadêmica.

Em primeiro lugar, agradeço à minha mãe, Liduina, por todo o apoio que me deu, sempre me incentivando e proporcionando o meu crescimento profissional. Agradeço também à Fátima, que tenho como uma segunda mãe, e à minha tia Ivanilce, que são outras duas pessoas de fundamental importância na construção de quem sou hoje. Ao meu pai, Ildenildo (in memoriam), sendo ele um dos meus maiores encorajadores em seguir o caminho acadêmico e da pesquisa, me apresentando, dentro dos seus limites, as mais diversas curiosidades no mundo da física, matemática, química e, em especial, da biologia. Outra pessoa que não posso deixar de agradecer, por ter sido um importante exemplo para mim, é o meu tio Francisco Osvanilson. Também agradeço o carinho da minha irmã, Ianna, e também por ela ter introduzido na nossa família a pequena princesa Emanuella. Sintam-se também agradecidos todos os meus demais familiares pelo apoio, carinho e torcida.

Agradeço pela oportunidade concedida e confiança empregada a mim pelo meu orientador, Dr. Rodrigo Panepucci. Aqui também agradeço a todos meus outros mestres, que me inspiraram, ensinaram e orientaram, dando destaque à $\operatorname{Dr}^{\mathrm{a}}$. Denise Crispim, minha orientadora de iniciação científica, à prof ${ }^{\mathrm{a}}$. Edileuza Melo, minha professora de biologia no ensino médio, e à professora Adélia Almeida, minha professora de ciências no ensino fundamental.

Agradeço imensamente a todos os meus amigos de laboratório, em especial à Josiane Schiavinato, à Sarah Blima e ao Hudson Bezerra, que tiveram um papel fundamental na execução de todo meu trabalho, até sua conclusão. Aos meus companheiros de pós-graduação Vitor Leão, Helder Freitas, Bruno Sangiorgi, Felipe Canto e Igor Coqueiro. Também não posso deixar de agradecer àquelas que, embora não tenham permanecido por todo o período do meu doutorado no mesmo laboratório, colaboraram imensamente com meu trabalho, 
minhas grandes amigas Danuta Sastre e Lara Zapata. Também à Amélia Góes, Claudia Avelar, Elizabete Figueiredo e Júlia Komoto, que mais do que funcionárias do laboratório, são amigas e cuidam de todos com um carinho muito especial.

Agradeço aqui à Susie Nalon, secretária do departamento de genética, que não mede esforços para nos ajudar em tudo o que for possível. Aproveito também para agradecer ao departamento de Genética da FMRP/USP, pelo curso e oportunidades oferecidas aos alunos. Também estendo os agradecimentos à Fundação de Amparo à Pesquisa do Estado de São Paulo (FAPESP) pela bolsa concedida, que me permitiu realizar todas as atividades ligadas ao doutorado, incluse com uma etapa no exterior, e ao Hemocentro de Ribeirão Preto e à FAEPA pelo apoio e estrutura oferecidos.

Muito obrigado a todos! 


\section{RESUMO}

LIMA, I.M.S. Identificação de vias moduladas por microRNAs na diferenciação celular e manutenção da pluripotência em células humanas. $238 \mathrm{f}$. Tese (Doutorado) - Faculdade de Medicina de Ribeirão Preto, Universidade de São Paulo, Ribeirão Preto, 2017.

Os microRNAs (miRs) desempenham um papel importante na biologia das células-tronco por meio da interação com seus mRNAs alvos, induzindo inibição da tradução e/ou degradação destes transcritos. Durante a diferenciação de células pluripotentes, os miRs podem ser induzidos ou reprimidos, no entanto, suas funções específicas são amplamente inexploradas. Nós investigamos os papéis funcionais de um conjunto selecionado de miRs na pluripotência e diferenciação celular, usando microscopia de fluorescência quantitativa (High Content Analysis). Para isso, foram empregadas a NTera-2 (células de carcinoma embrionário humano, CCE) e a H1 (células-tronco embrionárias humanas, CTEh) como modelos. Essas células foram transfectadas reversamente com trinta moléculas de miRs distintas (individualmente) ou moléculas controles. Após 3-4 dias de cultura, as células foram fixadas, permeabilizadas e coradas com Hoechst / CellMask Blue (núcleo/citoplasma), anti-OCT4, anti-Ciclina B1 e imageadas com um sistema ImageXpress Micro HCA. O CellProfiler foi utilizado para quantificar vários parâmetros morfométricos e medidas de intensidade de OCT4 e Ciclina B1 em compartimentos nucleares e citoplasmáticos. Esses dados foram usados para gerar perfis fenotípicos multiparamétricos específicos de cada miR (usando KNIME) e o agrupamento desses dados levou à identificação de vias e processos envolvidos na indução de características de pluripotência ou diferenciação celular causadas por miRs com efeitos fenotípicos similares. Como exemplo, as vias de PI3K-AKT, WNT, TGF $\beta$ e DICER foram encontradas como moduladas por alguns clusters fenotípicos e os transcritos de alguns alvos foram avaliados por qPCR para validar os achados. Parte do trabalho foi focada na regulação da via Notch por miRNAs em células pluripotentes, o que levou à observação de que o miR363-3p inibe a sinalização de Notch e promove pluripotência nessas células. A transfecção de miR-363-3p não apenas elevou as características de pluripotência em NTera-2 e H1, mas também protegeu as CCE da diferenciação induzida por cocultivo com OP9 expressando DLL1 e causou a diminuição no nível de transcritos de PSEN1. Em conclusão, o ensaio desenvolvido aqui provou ser uma ferramenta robusta na detecção de mecanismos moleculares, baseando-se na combinação de análises fenotípicas funcionais e bioinformáticas.

Palavras-chave: High Content Analysis, microRNAs, Pluripotência, Células-tronco embrionárias, Células de carcinoma embrionário. 


\begin{abstract}
LIMA, I.M.S. Identification of microRNA-modulated pathways in cell differentiation and pluripotency maintainance in human cells. $238 \mathrm{f}$. Thesis (Ph.D.) - School of Medicine of Ribeirão Preto, University of São Paulo, São Paulo, 2017.

microRNAs (miRs) play an important role in stem cell's biology by binding to target mRNAs transcripts, inducing translation blockage and/or transcripts degradation. Upon differentiation of pluripotent cells, miRNAs can be induced or repressed, however, their specific roles are largely unexplored. We investigated the functional roles of a selected set of miRs in pluripotency and differentiation, using quantitative automated fluorescence microscopy (High Content Analysis). For this, we used NTera-2 (human embryonal carcinoma cells, ECC) and H1 (embryonic stem cells; ESC) as models. These cells were reverse-transfected with thirty distinct miRs mimics (individually) or control molecules. Following 3-4 days of culture, cells were fixed, permeabilized and stained with Hoechst/CellMask Blue (nucleus/cytoplasm), antiOCT4, anti-Cyclin B1 and imaged using an ImageXpress Micro HCA System. CellProfiler was used to quantify several morphometric parameters and intensity measurements of OCT4 and CYCB1 in nuclear and cytoplasmic compartments. Quantified parameters were used to generate miR-specific multiparametric phenotypic profiles (using KNIME) and clustering these data led to identification of pathways and processes involved in the induction of pluripotency or cell diferention features caused by miRs with similar phenotypic effects. As an example, PI3K-AKT, WNT, TGF $\beta$ and DICER pathways were found to be regulated by some phenotypic clusters and transcripts level of some of miR targets were evaluated by qPCR to validate de findings. Part of the work was focused in the regulation of Notch pathway by miRNAs in pluripotent cells, which led the observation that miR-363-3p inhibits Notch signaling and promotes pluripotency feature, as the transfection with miR-363-3p mimic not only enhanced pluripotent phenotype in NTera- 2 and $\mathrm{H} 1$, but also protected de ECCs from differentiation induced by coculture with OP9 expressing DLL1 and decreased PSEN1 transcripts level.In conclusion, The assay developed here proved to be a robust tool in the detection of molecular mechanisms based on combined functional phenotypic and bioinformatic analyzes.
\end{abstract}

Keywords: High Content Analysis, microRNAs, Pluripotency, Embryonic Stem Cells, Embryonal Carcinoma Cells. 


\section{LISTA DE ILUSTRAÇÕES}

Figura 1. Representação da biogênese dos miRNAs.Da esquerda para a direita, inicialmente são visualizados os genes dos miRNAs no genoma, podendo ser localizados em regiões intrônicas ou intergênicas, e ainda em sequências policistrônicas. Estas sequências são então transcritas em grandes moléculas de RNA denominadas pri-miRNAs, as quais adotam uma conformação secundária por autocomplementariedade de bases. Essas estruturas são reconhecidas pelo complexo Drosha/DGCR8, sendo assim clivadas e dando origem a moléculas de RNA em hairpin conhecidas como pré-miRNAs. Os pré-miRNAs podem se originar também no processamento de mRNAs pelo spliceossomo (Mirtrons) ou de shRNAs endógenos. Por ação da Exportina 5, estas moléculas são transportadas para o citoplasma, onde são processadas pela Dicer, resultando na eliminação da estrutura de hairpin e em uma moléculas de dsRNA. Por atividade das argonautas, essa dupla fita é desfeita, sendo então uma das fitas simples (a fita guia) incorporada ao RISC (complexo de silenciamento induzido por RNA), que passa a ser conhecido como miRISC (complexo de silenciamento induzido por miRNA). A atividade deste complexo se dá pela sua ligação ao mRNA alvo com base na complementariedade entre o miRNA e seu alvo, que pode resultar na repressão da tradução ou degradação do mRNA por clivagem direta ou ainda desestabilização do transcrito por deadenilação. Adaptado de Rottiers e Näär (2012).

Figura 2. Possíveis aplicações práticas das células-tronco pluripontentes induzidas (iPSC).Um indivíduo pode fornecer células somáticas as quais serão reprogramadas, propagadas in vitro e, posteriormente, aplicadas para medicina regeneratica e personalisada, no desenvolvimento de drogas ou, ainda, no modelamento de doenças. Como exemplo, as iPSC podem ser diferenciadas em células específicas saudáveis (uso de terapia gênica, por exemplo) e reimplatadas no paciente. Ainda, essas células podem ser usadas para screening de drogas, com a finalidade de se desenvolver fármacos para uma doença específica ou para identificação de medicamentos que apresentem maior eficácia no tratamento de uma patologia, podendo ter sua eficiência testada para um paciente específico (medicina personalizada). Adaptado de Chun e colaboradores (2010).

Figura 3. Esquematização de algumas das principais vias de sinalização envolvidas na regulação da rede gênica que promove as características de pluripotência em células-tronco embrionárias murinas e humanas. Essas vias agem sobre o metabolismo dasa células-tronco embrionárias, bem como sobre a rede gênica que regula tanto o fenótipo pluripotente, quanto a diferenciação e determinação do destino celular.

Figura 4. Fotomicrografias de células das linhagens NTera-2 (A) e H1 (B) realizadas em microscópio invertido com contraste de fase. É visível o aspecto epitelial de ambas as linhagens celulares, com células justapostas e pouco alongadas. Percebe-se ainda que as células da linhagem NTera-2 são maiores e é de fácil identificação os limites entre uma célula e outra......

Figura 5. Células das linhagens H1 e NTera-2 marcadas com anticorpos para OCT4, SOX-2 e TRA-1-81. Foi realizada uma marcação nucelar com Hoechst 33342 (azul), uma imunomarcação indireta com anticorpos secundários conjugados ao fluorocromo DyLight 488 (verde) e a sobreposição das imagens.

Figura 6: Imagens geradas a partir de culturas de NTera- 2 em poços de uma placa de 96 poços, marcadas com Hoechst 33342, após os processos de fixação e permeabilização com 2\% de formol em PBS ou em metanol $(\mathrm{MeOH})$ gelado. Nota-se que, nos poços fixados com formol em PBS e posteriormente submetidos ao processo de permeabilização com detergente, há uma grande perda de células (evidenciado pela ausência de marcação de 
Hoechst 33342 no centro dos poços), enquanto naqueles fixados com formol em MeOH gelado não se observa uma perda significativa de células.

Figura 7. Fotomicrografia de células NTera-2 feitas por microscopia de fluorescência, onde são visualizadas as marcações para OCT4 (em verde) e para citoplasma (em vermelho). A) É possível se observar a grande quantidade de núcleos positivos para OCT4 (marcador de pluripotência). B) Culturas tratadas com ácido transretinóico (indutor de diferenciação celular) apresentam uma diminuição no número de células OCT4 positivas (Objetiva: 10X, ImageXpress).

Figura 8. Representação dos passos realizados para a segmentação das imagens de microscopia de fluorescência, utilizando o módulo de aplicação Multi-Wavelength Cell Scoring, do software MetaXpress, para a realização das análises de diferenciação e proliferação celular. Enquanto a análise de diferenciação se baseia nas alterações da porcentagem de células OCT4+ e das intensidades de fluorescência no canal de FITC, a análise de proliferação se baseia na contagem total de núcleos.

Figura 9. Esquemas de tratamentos nas placas de 96 poços próprias para imageamento. As bordas das placas foram preenchidas com PBS para evitar o efeito de borda, pois esta é uma área mais suscetível às variações de temperatura, humidade e modificações de atmosfera

Figura 10. Janela do CellProfiler onde são inseridos os endereços das imagens que serão analisadas, bem como os filtros para seleção das imagens de alta qualidade. 53

Figura 11. Janela do módulo de metadados no CellProfiler, onde são inseridos métodos de extração de metadados, os quais são utilizados pelo software e pelo analista para análises posteriores, pois neste momento são definidas informações como nome dos tratamentos e posicionamento destes nas placas de 96 poços.

Figura 12. Janela do módulo "nomes e tipos" no CellProfiler, onde são identificados os nomes das marcações correspondentes a cada um dos conjuntos de imagens obtidos pelos diferentes cubos de detecção de fluorescência. Neste caso, foram utilizados três cubos de detecção, sendo um para a marcação de núcleo e da célula (w1, cubo DAPI), outro para OCT4 (w2, cubo FITC) e um terceiro para Ciclina B1 (w3, cubo Texas Red).

Figura 13. Visualização de uma região de uma imagem feita com o cubo DAPI para deteção da marcação de Hoechst 33342 e CellMask®Blue, utilizando-se a ferramenta de visualização do CellProfiler. Em A, aplicou-se uma normalização em log da imagem, com uma atribuição de cores para diferentes intensidade de fluorescência (Heatmap definido por uma "Look up Table" - LUT), permitindo a observação dos núcleos com maior intensidade de fluorescência (entre vermelho e amarelo), do citoplasma com intensidade intermediária (em verde), e do background com intensidade baixas (em azul). Em B, pode-se ver a segmentação obtida pelo software, com um delineamento em preto para o núcleo e em vermelho para os limites celulares. A partir destas delimitações, são gerados as mascaras com os objetos núcleo (C), célula (D) e citoplasma (E), este último definido subtraindo-se a mascara do núcleo da mascara da célula.

Figura 14. Representações gráficas dos resultados obtidos da transfecção de culturas de células NTera-2 com as moléculas sintéticas miméticas de miR-302b-3p, miR-29b-3p e miR-CTRL (controle; PMC). A) A presença do miR-29b-3p induziu uma redução estatisticamente significativa na quantidade de OCT4 no núcleo, visualizada pela quantificação da intensidade de fluorescência média no canal de FITC; B) As porcentagens de núcleos positivos para a marcação de OCT4 não foram diferentes quando comparados os miRNAs testes com o controle, porém, entre si, foram observadas diferenças significativas, onde o miR-302-3p induziu um aumento, enquanto o 
miR-29b-3p induziu uma redução na quantidade de núcleos positivos para OCT4; C) As culturas tratadas com o pré-miR-302-3p apresentaram uma área celular significativamente menor do que as tratadas com miR-29b-3p, mas esta diferença não foi visível quando os grupos transfectados com estes miRNAs foram comparados ao grupo PMC. ** valor de $\mathrm{P}<0,01 ; * * *$ valor de $\mathrm{P}<0,0001$

Figura 15. De "A" a "C" estão representados os resultados obtidos na linhagem NTera-2 após tratamento com: miR controle negativo (PMC), PMC seguido de tratamneto com ácido trans-retinóico, esiRNA-OCT4 e siRNAUBC. Os resultados refetenres aos mesmos tratamentos na linhagem H1 se encontram de "D" a "E". O tempo de transfecção para a linhagem NTera-2 foi de 4 dias, sendo o grupo que recebeu atRA mantido em contato com este por 3 dias, enquanto para H1 o tempo de transfecção foi de 3 dias e de tratamento com atRA de 2 dias. A e D) A transfecção com o siRNA-UBC levou a uma redução significativa do número de células, tanto para a linhagem H1 quanto para NTera-2, enquanto o esiRNA-OCT4 também reduziu o número de células H1 após a incubação. B) O tratamento com atRA não alterou significativamente a área das células, enquanto os esiRNAOCT4 e siRNA-UBC levaram a um aumento estatisticamente significativo no tamanho celular, tanto para H1 quanto para NTera-2. C) Em ambas as linhagens celulares, todos os tratamentos levaram a uma redução significativa nos níveis de OCT4 nuclear. $* *=\mathrm{P}<0,01, * * *=\mathrm{P}<0,0001$.

Figura 16. Fotomicrografias da linhagem NTera-2 marcada com Hoechst 33342 e CellMask®Blue (azul), antiOCT4 (verde) e anti-CCNB1 (laranja) após transfectadas com miR controle negativo (PMC), esiRNA-OCT4, siRNA-UBC e também após o tratamento com atRA $(10 \mu \mathrm{M})$. Essas células foram mantidas em cultura por 4 dias após a transfecção, e o grupo PMC+atRA tratado com o indutor de diferenciação por 3 dias. Com o fim da incubação, as células foram fixadas, marcadas e imageadas, para então serem analisadas por meio do CellProfiler para a aquisição dos dados quantitativos que deram origem ao perfil fenotípico de cada tratamento. É possível notar a alta expressão de OCT4 nas células de PMC pela grande quantidade de verde no núcleo. Todos os tratamento causaram uma redução nesta marcação. Alguns outros efeitos como aumento da área celular e diminuição do número total de células também podem ser notados, sendo que esta diminuição foi somente no tratamento com o siRNA citotóxico contra UBC.

Figura 17. Fotomicrografias da linhagem H1 marcada com Hoechst 33342 e CellMask ${ }^{\circledR B l u e}($ azul), anti-OCT4 (verde) e anti-CCNB1 (laranja) após transfectadas com miR controle negativo (PMC), esiRNA-OCT4, siRNAUBC e também após o tratamento com atRA $(10 \mu \mathrm{M})$. Essas células foram mantidas em cultura por 3 dias após a transfecção, e o grupo PMC+atRA tratado com o indutor de diferenciação por 2 dias. Com o fim da incubação, as células foram fixadas, marcadas e imageadas, para então serem analisadas por meio do CellProfiler para a aquisição dos dados quantitativos que deram origem ao perfil fenotípico de cada tratamento. É possível notar a alta expressão de OCT4 nas células de PMC pela grande quantidade de verde no núcleo e como os outros tratamentos reduziram esta marcação. Alguns outros efeitos como aumento da área celular e diminuição do número total de células também podem ser notados, particularmente mais evidentes na figura representativa do grupo tratado com o siRNA-UBC.

Figura 18. Clusterização realizada a partir da avaliação dos efeitos fenotípicos induzidos por cada tratamento controle (PMC, PMC+atRA, esiRNA-OCT4 e siRNA-UBC) nas duas placas diferentes (P1 e P2) que constituiam os ensaios para estudas os miRNAs selecionados nas duas linhagens pluripotentes, NTera-2 (NT2, figura à esquerda) e H1 (figura à direita). Essas clusterizações foram realizadas baseando-se nos dados quantitativos da análise de imagens de fluorescência, por meio do CellProfiler, utilizando um conjunto de 13 
parâmetros para definir o perfil fenotípico de cada tratamento. No heatmap, onde azul brilhante representa o menor valor, amarelo brilhante o maior e preto o valor central (do PMC), são apresentas as medidas relativas dos traços fenotípicos selecionados, resultantes da normalização de cada tratamento pelo controle negativo (PMC) com o uso de ferramentas do KNIME. Nota-se que os mesmos tratamentos realizados nas duas diferentes placas se agruparam de acordo com as características apresentadas, demonstrando assim a robustez do ensaio, bem como sua capacidade de identificar alterações na morfologia e expressão de OCT4 e CCNB1 induzidas por tratamentos com moléculas com ação similar sobre as células pluripotentes.

Figura 19. Os diagramas de Venn apresentados aqui representam a comparação dos ensaios funcionais em NTera-2 (NT2) e H1 (A), e entre os resultados observados com as transfecções e o esperado, baseado na literatura científica (B). Para confecção dos diagramas, foi utilizada a ferramenta Venny 2.1 (http://bioinfogp.cnb.csic.es/tools/venny/) A) Baseando-se na intensidade de fluorescência nuclear mediana para OCT4, os miRNAs foram classificados como pró-pluripotência, induzindo o aumento de OCT4 (OCT4Hi[High]), e pró-diferenciação celular (OCT4-Lo[Low]). Dos 31 miRNAs testados, 25 apresentaram resultados concordantes entre as duas linhagens de células pluripotentes humanas, sendo 16 indutores de um fenótipo pluripotente e 9, de diferenciação. B) Os 25 miRNAs que apresentaram efeitos concordantes em NT2 e H1 tiveram sua atividade funcional comparada com o esperado. Daqueles com atividade pró-pluripotência (OCT4Hi), 13 se comportaram congruentemente ao esperado, e dos 9 com efeito pró-diferenciação, 7 se enquadraram com o expectável.

Figura 20. Clusterização dos miRNAs pelos seus efeitos fenotípicos na linhagem NTera-2, baseando-se em dados quantitativos da análise de imagens de fluorescência, por meio do CellProfiler, de células transfectadas com miR mimics e controle negativo. No heatmap, onde azul brilhante representa um menor valor, amarelo brilhante representa um maior e preto seria o valor central, são apresentas as medidas relativas dos traços fenotípicos selecionados, resultantes da normalização de cada tratamento pelo controle negativo (PMC) com o uso de ferramentas do KNIME. De acordo com os perfis induzidos por cada miRNA, foram identificados dois grandes clusters, sendo o cluster A formado por miRNAs que induziram diferenciação celular e o cluster B, por aqueles que promoveram características de pluripotência. Estes clusters ainda foram subdivididos de acordo, principalmente, com as semelhanças e diferenças morfológicas observadas em cada tratamento. .76

Figura 21. Gráficos de dispersão apresentando os resultados em porcentagem (relativos ao grupo controle negativo) de cada sítio (pontos pretos) das replicatas (poço) de tranfecção com os diferentes miR mimics na linhagem NTera-2. Aqui se encontram apresentados os efeitos destas moléculas sobre as quantificações de OCT4 no núcleo e citoplasma, representadas pelas intensidades medianas de OCT4 nuclear (A) ou citoplasmática (B). A linha tracejada vermelha (na horizontal) representa a mediana do grupo controle, enquanto os clusters de miRNAs, gerados na clusterização fenotípica, se encontram separados pelas listas tracejadas azúis (na vertical).

Figura 22. Gráficos de dispersão apresentando os resultados em porcentagem (relativos ao grupo controle negativo) de cada sítio (pontos pretos) das replicatas (poço) de tranfecção com os diferentes miR mimics na linhagem NTera-2. Aqui se encontram apresentados os efeitos destas moléculas sobre as quantificações de CCNB1 no núcleo e citoplasma, representadas pelas intensidades medianas de CCNB1 nuclear (A) ou citoplasmática (B). A linha tracejada vermelha (na horizontal) representa a mediana do grupo controle, enquanto 
os clusters de miRNAs, gerados na clusterização fenotípica, se encontram separados pelas listas tracejadas azúis (na vertical).

Figura 23. Gráficos de dispersão apresentando os resultados em porcentagem (relativos ao grupo controle negativo) de cada sítio (pontos pretos) das replicatas (poço) de tranfecção com os diferentes miR mimics na linhagem NTera-2. Aqui se encontram apresentados os efeitos destas moléculas sobre o tamanho das células, representados pela área (A) e perímetro (B) celulares medianos. A linha tracejada vermelha (na horizontal) representa a mediana do grupo controle, enquanto os clusters de miRNAs, gerados na clusterização fenotípica, se encontram separados pelas listas tracejadas azúis (na vertical).

Figura 24. Gráficos de dispersão apresentando os resultados em porcentagem (relativos ao grupo controle negativo) de cada sítio (pontos pretos) das replicatas (poço) de tranfecção com os diferentes miR mimics na linhagem NTera-2. Aqui se encontram apresentados os efeitos destas moléculas sobre a complexidade das células, representados pela quantificação da excentricidade celular (\%) (A) e solidez celular (\%) (B) medianas. A linha tracejada vermelha (na horizontal) representa a mediana do grupo controle, enquanto os clusters de miRNAs, gerados na clusterização fenotípica, se encontram separados pelas listas tracejadas azúis (na vertical).

Figura 25. Gráficos de dispersão apresentando os resultados em porcentagem (relativos ao grupo controle negativo) de cada sítio (pontos pretos) das replicatas (poço) de tranfecção com os diferentes miR mimics na linhagem NTera-2. Aqui se encontram apresentados os efeitos destas moléculas sobre o tamanho dos núcleos celulares, representados pela quantificação da área (A) e perímetro (B) nucleares medianos. A linha tracejada vermelha (na horizontal) representa a mediana do grupo controle, enquanto os clusters de miRNAs, gerados na clusterização fenotípica, se encontram separados pelas listas tracejadas azúis (na vertical).

Figura 26. Gráficos de dispersão apresentando os resultados em porcentagem (relativos ao grupo controle negativo) de cada sítio (pontos pretos) das replicatas (poço) de tranfecção com os diferentes miR mimics na linhagem NTera-2. Aqui se encontram apresentados os efeitos destas moléculas sobre a complexidade dos núcleos celulares, representados pela quantificação da excentricidade (A) e solidez (B) nucleares medianas. A linha tracejada vermelha (na horizontal) representa a mediana do grupo controle, enquanto os clusters de miRNAs, gerados na clusterização fenotípica, se encontram separados pelas listas tracejadas azúis (na vertical).

Figura 27. Gráfico de dispersão apresentando os resultados em porcentagem (relativos ao grupo controle negativo) de cada sítio (pontos pretos) das replicatas (poço) de tranfecção com os diferentes miR mimics na linhagem NTera-2. Aqui se encontram apresentados os efeitos destas moléculas sobre o número de células encontrado por sítio em cada replicata (poço), representado pela contagem de células mediana. A linha tracejada vermelha (na horizontal) representa a mediana do grupo controle, enquanto os clusters de miRNAs, gerados na clusterização fenotípica, se encontram separados pelas listas tracejadas azúis (na vertical).

Figura 28. Clusterização dos miRNAs por seus efeitos fenotípicos sobre a linhagem H1, baseando-se nos dados quantitativos gerados da análise de imagens de fluorescência, por meio do CellProfiler, de células transfectadas com miR mimics e controle negativo (PMC). No heatmap, onde azul brilhante representa um menor valor, amarelo brilhante representa um maior e preto seria o valor central, são apresentas as medidas relativas dos traços fenotípicos selecionados, resultantes da normalização de cada tratamento pelo controle negativo com o uso de ferramentas do KNIME. De acordo com os perfis induzidos por cada miRNA, foram identificados três 
clusters principais, sendo os cluster A e B.2 formados por miRNAs que induziram diferenciação celular, e os clusters B.1 e C, por aqueles que promoveram características de pluripotência. Os subclusters identificados originaram-se, principalmente, pelas semelhanças e diferenças morfológicas observadas em cada tratamento...85

Figura 29. Gráficos de dispersão apresentando os resultados em porcentagem (relativos ao grupo controle negativo) de cada sítio (pontos pretos) das replicatas (poço) de tranfecção com os diferentes miR mimics na linhagem H1. Aqui se encontram apresentados os efeitos destas moléculas sobre as quantificações de OCT4 no núcleo e citoplasma, representadas pelas intensidades medianas de OCT4 nuclear (A) ou citoplasmática (B). A linha tracejada vermelha (na horizontal) representa a mediana do grupo controle, enquanto os clusters de miRNAs, gerados na clusterização fenotípica, se encontram separados pelas listas tracejadas azúis (na vertical).

Figura 30. Gráficos de dispersão apresentando os resultados em porcentagem (relativos ao grupo controle negativo) de cada sítio (pontos pretos) das replicatas (poço) de tranfecção com os diferentes miR mimics na linhagem H1. Aqui se encontram apresentados os efeitos destas moléculas sobre as quantificações de CCNB1 no núcleo e citoplasma, representadas pelas intensidades medianas de CCNB1 nuclear (A) ou citoplasmática (B). A linha tracejada vermelha (na horizontal) representa a mediana do grupo controle, enquanto os clusters de miRNAs, gerados na clusterização fenotípica, se encontram separados pelas listas tracejadas azúis (na vertical).

Figura 31. Gráficos de dispersão apresentando os resultados em porcentagem (relativos ao grupo controle negativo) de cada sítio (pontos pretos) das replicatas (poço) de tranfecção com os diferentes miR mimics na linhagem H1. Aqui se encontram apresentados os efeitos destas moléculas sobre o tamanho das células, representados pela área (A) e perímetro (B) celulares medianos. A linha tracejada vermelha (na horizontal) representa a mediana do grupo controle, enquanto os clusters de miRNAs, gerados na clusterização fenotípica, se encontram separados pelas listas tracejadas azúis (na vertical).

Figura 32. Gráficos de dispersão apresentando os resultados em porcentagem (relativos ao grupo controle negativo) de cada sítio (pontos pretos) das replicatas (poço) de tranfecção com os diferentes miR mimics na linhagem H1. Aqui se encontram apresentados os efeitos destas moléculas sobre a complexidade das células, representados pela quantificação da excentricidade celular (\%) (A) e solidez celular (\%) (B) medianas. A linha tracejada vermelha (na horizontal) representa a mediana do grupo controle, enquanto os clusters de miRNAs, gerados na clusterização fenotípica, se encontram separados pelas listas tracejadas azúis (na vertical). 90

Figura 33. Gráficos de dispersão apresentando os resultados em porcentagem (relativos ao grupo controle negativo) de cada sítio (pontos pretos) das replicatas (poço) de tranfecção com os diferentes miR mimics na linhagem H1. Aqui se encontram apresentados os efeitos destas moléculas sobre o tamanho dos núcleos celulares, representados pela quantificação da área (A) e perímetro (B) nucleares medianos. A linha tracejada vermelha (na horizontal) representa a mediana do grupo controle, enquanto os clusters de miRNAs, gerados na clusterização fenotípica, se encontram separados pelas listas tracejadas azúis (na vertical).

Figura 34. Gráficos de dispersão apresentando os resultados em porcentagem (relativos ao grupo controle negativo) de cada sítio (pontos pretos) das replicatas (poço) de tranfecção com os diferentes miR mimics na linhagem H1. Aqui se encontram apresentados os efeitos destas moléculas sobre a complexidade dos núcleos celulares, representados pela quantificação da excentricidade (A) e solidez (B) nucleares medianas. A linha 
tracejada vermelha (na horizontal) representa a mediana do grupo controle, enquanto os clusters de miRNAs, gerados na clusterização fenotípica, se encontram separados pelas listas tracejadas azúis (na vertical).

Figura 35. Gráfico de dispersão apresentando os resultados em porcentagem (relativos ao grupo controle negativo) de cada sítio (pontos pretos) das replicatas (poço) de tranfecção com os diferentes miR mimics na linhagem H1. Aqui se encontram apresentados os efeitos destas moléculas sobre o número de células encontrado por sítio em cada replicata (poço), representado pela contagem de células mediana. A linha tracejada vermelha (na horizontal) representa a mediana do grupo controle, enquanto os clusters de miRNAs, gerados na clusterização fenotípica, se encontram separados pelas listas tracejadas azúis (na vertical). .93

Figura 36. Gráficos de quantificação relativa (2^-ddCt) para os genes STAT3, APC, KLF4, FGFR1, RELA, LIF, $T G F B 3, I G F 1 R$, IL2RA e CDKN2B em células NTera-2 transfectadas com miR-29b-3p pelo e incubadas por 48h em condições de cultivo, comparadas com células transfectadas com o controle negativo (PMC). Essas análises demonstraram que o miRNA em questão reduziu os níveis transcricionais, de forma estatisticamente significativa $(\mathrm{P}<0,05)$, para $A P C$ e $K L F 4$, e levou a um aumento na quantificação de CDKN2B. * $=\mathrm{P}<0,05 \ldots 101$ Figura 37. Gráficos de quantificação relativa $\left(2^{\wedge}-\mathrm{ddCt}\right)$ para os genes $G S K 3 B, B M P R 2, S M A D 2, T G F B R 2$, CDK6, MAPK1, IL6ST, TCF3, PTEN e FGF2 em células NTera-2 transfectadas miR mimics representantes dos miRNAs dos clusters fenotípicos (NTera-2/H1) identificados, sendo eles: miR-18b-5p (B.1/B.1), miR-20a-5p (A1/C1), miR-23a-3p (A.2/C1), miR-24-3p (A.2/B.1), miR-30a-5p (A.2/A), miR-92a-3p (B.2a/C.2c), miR-181d5p (B.2b/C.1), miR-222-3p (B.1/C.2b), miR-302a-3p (B.2a/C.2b), miR-363-3p (B.1/B.1), miR-371a-3p (B.2b/C.2c), miR-373-3p (B.2b/C.2a). Essas células foram cultivadas pelo período de 48h e tiveram seu RNA total extraído, do qual foi feito o cDNA para quantificação por qPCR. As análises foram relativos ao grupo transfectado com a molécula de controle negativo (PMC). Nota-se que alguns miRNAs levaram à redução na quantificação de transcritos para a grande maioria dos genes estudados, resultado este que pode validar a ação dos miRNAs na regulação das vias identificadas pela ferramenta DAVID, a partir da identificação de alvos por uma abordagem in silico. $*=\mathrm{P}<0,05$.

Figura 38. Esquema da via de sinalização de Notch obtido pela base de dados KEGG. Nela, podem ser observados os componentes principais da via e como se dá o controle da sinalização, desde sua ativação na membrana até o efeito de regulação transcricional.

Figura 39. Gráficos apresentando a avaliação do efeito de miRNAs que promoveram características de pluripotência no ensaio funcional sobre a via de sinalização Notch. Estes dados foram obtidos a partir do ganho de função dos miRNAs na linhagem NTera-2, que foi cocultivada com OP9-DL1 ou OP9-Ctrl (A e B), para uma avaliação funcional, ou que teve seu mRNA total extraído após a transfecção, seguida da quantificação de componentes da via Notch (C e D). A) Comparação entre a linhagem NTera-2 transfectada com a molécula de controle negativo (PMC) e cocultivada com as linhagens OP9-ctrl ou OP9-DL1. A quantificação nuclear de OCT4 demonstrou um perda desta proteína no grupo NTera-2/OP9-DL1, indicando um efeito indutor de diferenciação pela ativação de Notch pelo ligante DLL1. B) A comparação entre células NTera-2 transfectadas com os diferentes miRNAs e com o PMC, posteriormente cocultivadas com OP9-DL1, demonstrou que o miR363-3p induziu um efeito protetor sobre a diferenciação celular induzida por Notch. C) A quantificação dos transcritos de NOTCH2 demonstrou uma diminuição em células NTera-2 transfectadas com o miR-363-3p, em comparação ao controle negativo (PMC). D) O nível de transcritos de PSEN1 foi reduzido de modo significativo $(\mathrm{P}<0,05)$ em culturas de NTera-2 transfectadas com o miR-363-3p, em comparação à transfecção com PMC. 105 


\section{LISTA DE TABELAS}

Tabela 1. Relação dos miRNAs selecionados para avaliação de efeito modulatório sobre o fenótipo pluripotente de células humanas.

Tabela 2. Lista de sondas utilizadas para a detecção de transcritos de genes identificados nas análises de vias moduladas pelos miRNAs

Tabela 3. Lista de primers de DNA utilizados para a deteção de transcritos de genes identificados nas análises de vias moduladas pelos miRNAs

Tabela 4. Genes alvos de cada subcluster separados de acordo com a via biológica detectada pela ferramenta

DAVID. No presente caso, encontram-se descritos os dados do cluster A na linhagem NTera-2.

Tabela 5. Genes alvos de cada subcluster separados de acordo com a via biológica detectada pela ferramenta DAVID. No presente caso, encontram-se descritos os dados do cluster B na linhagem NTera-2....

Tabela 6. Aqui se encontram apresentados os genes alvos de cada subcluster separados de acordo com a via biológica detectada pela ferramenta DAVID. No presente caso, encontram-se descritos os dados dos clusters A e B na linhagem $\mathrm{H} 1$

Tabela 7. Aqui se encontram apresentados os genes alvos de cada subcluster separados de acordo com a via biológica detectada pela ferramenta DAVID. No presente caso, encontram-se descritos os dados do cluster C na linhagem $\mathrm{H} 1$.

Tabela 8. Lista de genes componentes da via de sinalização Notch e dos miRNAs que os alvejam. Esta lista foi gerada a partir da informação contida no banco de dados Target Scan 7 


\section{LISTA DE ABREVIATURAS}

- $\quad$ atRA = do inglês "all-trans Retinoic Acid";

- Ago = proteínas Argonautas;

- $\mathrm{CCE}=$ Células de Carcinoma Embrionário;

- $\mathrm{Ct}=$ do inglês "Cycle Threshold";

- $\quad \mathrm{CTE}=$ Células-Tronco Embrionárias;

- $\quad \mathrm{CTEh}=$ Célula-Tronco Embrionária Humana;

- $\mathrm{Ctrl}=$ Controle;

- $\quad$ DAPI = 4',6-diamidino-2-fenilindol

- DNA = do inglês "Desoyribonucleic acid";

- DMEM = do inglês “Dulbecco's Modified Eagle's Medium";

- $\quad$ DMSO = Dimetilsulfóxido;

- dsRNA = do inglês "Double-Stranded RNA";

- $\quad \mathrm{EMT}=$ do inglês "Epithelial-Mesenchymal Transition";

- $\quad$ esiRNA = do inglês "Endoribonuclease-Prepared Small Interfering RNA";

- $\mathrm{HCA}=$ do ingles "High Content Analysis";

- $\mathrm{HCS}=$ do inglês "High Content Screening”;

- HTS = do inglês "High Throughput Screening";

- $\quad$ iPSC $=$ do inglês "Induced Pluripotent Stem Cells";

- $\mathrm{MEF}=$ do inglês "Mouse Embryonic Fibroblasts";

- $\mathrm{MeOH}=$ Metanol;

- $\mathrm{MET}=$ do inglês "Mesenchymal-Epithelial Transition";

- $\quad$ miR ou miRNA = microRNA;

- $\quad$ miRISC $=$ do inglês "miRNA-induced silencing complex";

- $\quad$ mRNA= RNA mensageiro;

- $\mathrm{NCM}=$ do inglês "Non Colony Monolayer";

- $\mathrm{nt}=$ nucleotídios;

- $\mathrm{OKS} / \mathrm{M}=$ OCT4, KLF4, SOX2 /e cMYC; 
- $\mathrm{PBS}=$ do inglês "Phosphate Buffered Saline";

- $\mathrm{PCR}=$ do inglês "Polimerase Chain Reaction";

- $\quad \mathrm{POC}=$ do inglês "Percentage of Control";

- $\quad$ ISC $=$ do inglês " $R N A$-induced silencing complex";

- $\quad$ RNA = do inglês "Ribonucleic acid";

- $\mathrm{SFB}=$ Soro Fetal Bovino;

- $\quad \mathrm{TA}=$ Temperatura de Anelamento;

- $\quad$ TLR = do inglês "Toll-like receptors";

- $\mathrm{UBC}=$ Ubiquitina $\mathrm{C}$. 


\section{SUMÁRIO}

1. Introdução

1.1 Os microRNAs e a regulação da expressão gênica ....................................................................2 23

1.2 Células-Tronco, Pluripotência e Diferenciação Celular ................................................................2 27

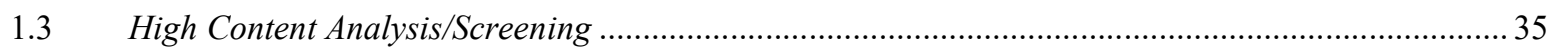

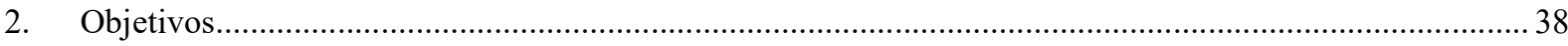

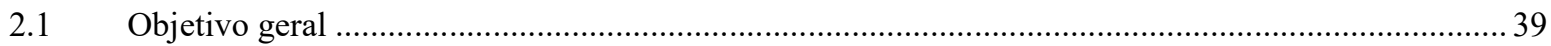

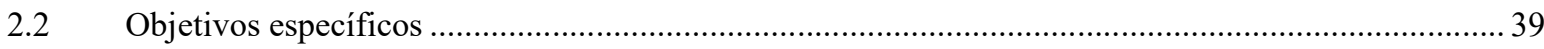

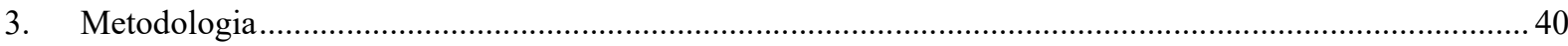

Linhagens celulares e condições de cultivo ............................................................................ 41

3.2 Definição do protocolo de imunomarcação …........................................................................4 44

3.3 Validação funcional do ensaio para avaliação da modulação da pluripotência................................. 47

3.4 Ensaio para avaliação do efeito dos miRNAs sobre a plutipotência em células humanas .................48

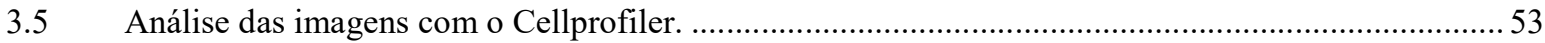

3.6 Agrupamento dos tratamentos miRNAs por similaridades fenotípicas induzidas ............................58

3.7 Predição in silico dos alvos e vias regulados pelos clusters de miRNAs.......................................5 59

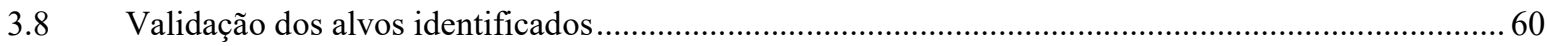

3.9 Regulação de miRNAs sobre a diferenciação induzida pela via Notch ...............................................64

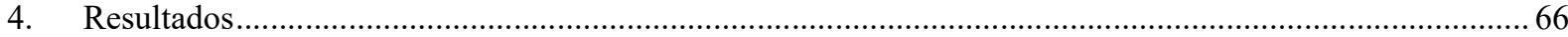

4.1 Validação funcional do ensaio para detecção da modulação da pluripotência.................................. 67

4.2 Perfis fenotípicos induzidos por miRNAs em células-tronco pluripotentes humanas .......................68

4.2.1 Alterações fenotípicas induzidas por miRNAs na linhagem NTera-2 …..................................... 75

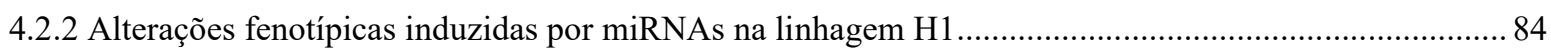

4.3 Identificação de alvos e vias reguladas pelos miRNA dos diferentes clusters ...............................93

4.3.1 Alvos e vias regulados pelos clusters de miRNAs na linhagem NTera-2 _......................................93

4.3.2 Alvos e vias regulados pelos clusters de miRNAs na linhagem H1 ............................................. 97

4.3.3 Validação da ação reguladora dos miRNAs por qPCR …........................................................... 100

4.4 O papel dos miRNA pró-pluripotência na regulação da via Notch............................................ 103

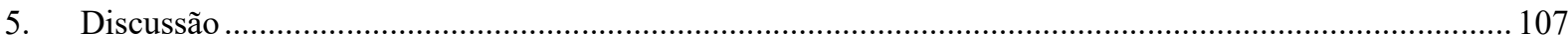

5.1 NTera-2 e H1 como modelos de estudo da pluripotência 108 
5.2 Regulação da transição epitelial-mesenquimal por miRNAs capazes de promover diferenciação em células pluripotentes humanas

5.3 miRNAs que regulam o complexo RISC promovem perfís fenotípicos associados à pluripotência em células pluripotentes humanas

5.4 Regulação de PI3K-AKT e mTOR por miRNAs pode induzir diferenciação celular ou características relacionadas pluripotência em células-tronco humanas.

5.5 miRNAs promovem diferenciação celular por inibição seletiva de componentes da via TNF e atuam sobre a via dos Toll-like receptors para promoverem pluripotência

5.7 Inibição da via Notch por miRNAs promove pluripotência em células-tronco embrionárias e células de carcinoma embrionário humanas.

6. Conclusões.

7. Referências Bibliográficas.

8. Anexos

Anexo I

Anexo II

Anexo III

Anexo IV

Anexo V - Manuscrito do presente estudo EM PREPARAÇÃO 


\subsection{Os microRNAs e a regulação da expressão gênica}

O estudo do desenvolvimento larval de uma espécie de nematódeo da família Rhabditidae, o Caenorhabditis elegans, levou a identificação de genes heterocrônicos, os quais regulam de forma temporal o destino das células deste organismo, controlando assim os eventos pós-embrionários que determinam a produção de linhagens celulares no indivíduo durante seu amadurecimento (AMBROS, 1989; AMBROS; HORVITZ, 1984, 1987; CHALFIE; HORVITZ; SULSTON, 1981). O C. elegans passa por diferentes estágios larvais (L1, L2, L3 e L4) até alcançar a fase adulta, onde a diferenciação somática é completa e o animal atinge sua maturidade sexual, onde o marco de término de cada fase se dá pela secreção de uma cutícula colagenosa pelas células epidermais e eliminação da cutícula antiga (ROUGVIE; MOSS, 2013).

O gene lin-4 faz parte do grupo de genes reguladores do desenvolvimento larval de $C$. elegans identificados nos estudos citados anteriormente. Ele participa dos eventos que levam à passagem do animal por essencialmente todos os estágios larvais. Em animais onde lin-4 teve sua função perdida por meio de mutações, foram observadas a ausência de estruturas adultas e problemas na postura de ovos, resultantes de um retardo no desenvolvimento destes animais, os quais apresentavam padrões celulares característicos de L1 em estágios larvais tardios. Por outro lado, quando estudados animais com perda de função de um outro gene, o lin-14, o qual também faz parte do grupo de genes anteriormente citado, foram observadas alterações no desenvolvimento larval opostas ao observado naqueles animais com perda de função de lin-4. Somando-se a esta observação, ensaios de ganho de função de lin-14 resultaram na observação de alterações fenotípicas similares àquelas vistas com a perda de lin-4. Essa soma de evidências levou a pensar que lin-4 regularia a função de lin-14 durante o desenvolvimento de C. elegans e esta regulação se daria de uma forma pós-trancricional, já que os níveis proteicos de lin-14 diminuíam conforme a progressão do desenvolvimento larval, mas os níveis de seus transcritos se mantinham praticamente inalterados (AMBROS, 1989; AMBROS; HORVITZ, 1987; CHALFIE; HORVITZ; SULSTON, 1981; RUVKUN; GIUSTO, 1989).

Ao estudarem como se dava esta regulação de lin-4 sobre lin-14, pesquisadores identificaram que lin-4 se encontrava numa região intrônica e não codificava nenhuma proteína, mas sim dois pequenos transcritos, sendo um de aproximadamente 61 nucleotídios (nt) e outro com cerca de 22nt. Além disso, detectaram que o RNA mensageiro (mRNA) de 
lin-14 possui regiões com sequências complementares a estes pequenos RNAs, propondo então que estes pequenos RNAs seriam os responsáveis por regular negativamente a tradução da proteína LIN-14 ao se ligar por complementariedade de bases na região 3'UTR (untranslated region; região não traduzida) do transcrito de seu mRNA (LEE; FEINBAUM; AMBROS, 1993).

Desta maneira foi identificado o primeiro pequeno RNA de uma classe de RNAs não codificadores, que ficaram conhecidos como microRNAs (miRNAs), os quais regulam a expressão gênica de maneira pós-trancricional (BARTEL; LEE; FEINBAUM, 2004; PILLAI, 2005). Um segundo trabalho apresentou o miRNA let-7 como outro regulador do desenvolvimento de C. elegans (REINHART et al., 2000) e, a partir de então, o interesse sobre os miRNAs foi crescente na comunidade científica, conduzindo a exploração do papel destas moléculas nas mais diferentes situações e espécies.

Sabe-se que os miRNAs podem ser inicialmente transcritos como longas moléculas de RNA (os pri-miRNAs), por atividade das RNA polimerases II ou III (BORCHERT; LANIER; DAVIDSON, 2006; LEE et al., 2004), a partir de regiões intergênicas ou intragênicas, sendo em várias ocasiões encontrados em loci genômicos policistrônicos. Essa grande molécula adquire uma estrutura secundária por complementariedade de bases dentro da própria molécula, sendo esta reconhecida e processada por um complexo RNAse do tipo III (Drosha e DGCR8). Esse processamento leva à geração de moléculas menores, os pré-miRNAs, que apresentam uma estrutura de hairpin e são transportados para o citoplasma, onde novamente serão processados pela Dicer (que remove a alça que une as duas fitas complementares), dando origem aos miRNAs maduros de dupla fita, com cerca de 22nt. Pela atividade de proteínas do tipo argonauta (Ago), esse RNA dupla fita (dsRNA) é desfeito e uma das fitas (conhecida como fita guia) se incorpora a um complexo proteico denominado RISC ( $R N A$ induced silencing complex; complexo de silenciamento induzido por RNA), resultando no miRISK (miRNA-induced silencing complex; complexo de silenciamento induzido por miRNA). Por fim, o miRISK pode se ligar ao(s) seu(s) mRNA(s) alvo(s) (por complementariedade de bases, total ou parcial, com a fita guia de miRNA) e inibir a produção da proteína codificada por este(s) (FILIPOWICZ; BHATTACHARYYA; SONENBERG, 2008; GRISHOK et al., 2001; HUTVÁGNER et al., 2001; LAGOS-QUINTANA et al., 2001; SIOMI; SIOMI, 2010; ZAMORE et al., 2000; ZENG; WAGNER; CULLEN, 2002). 


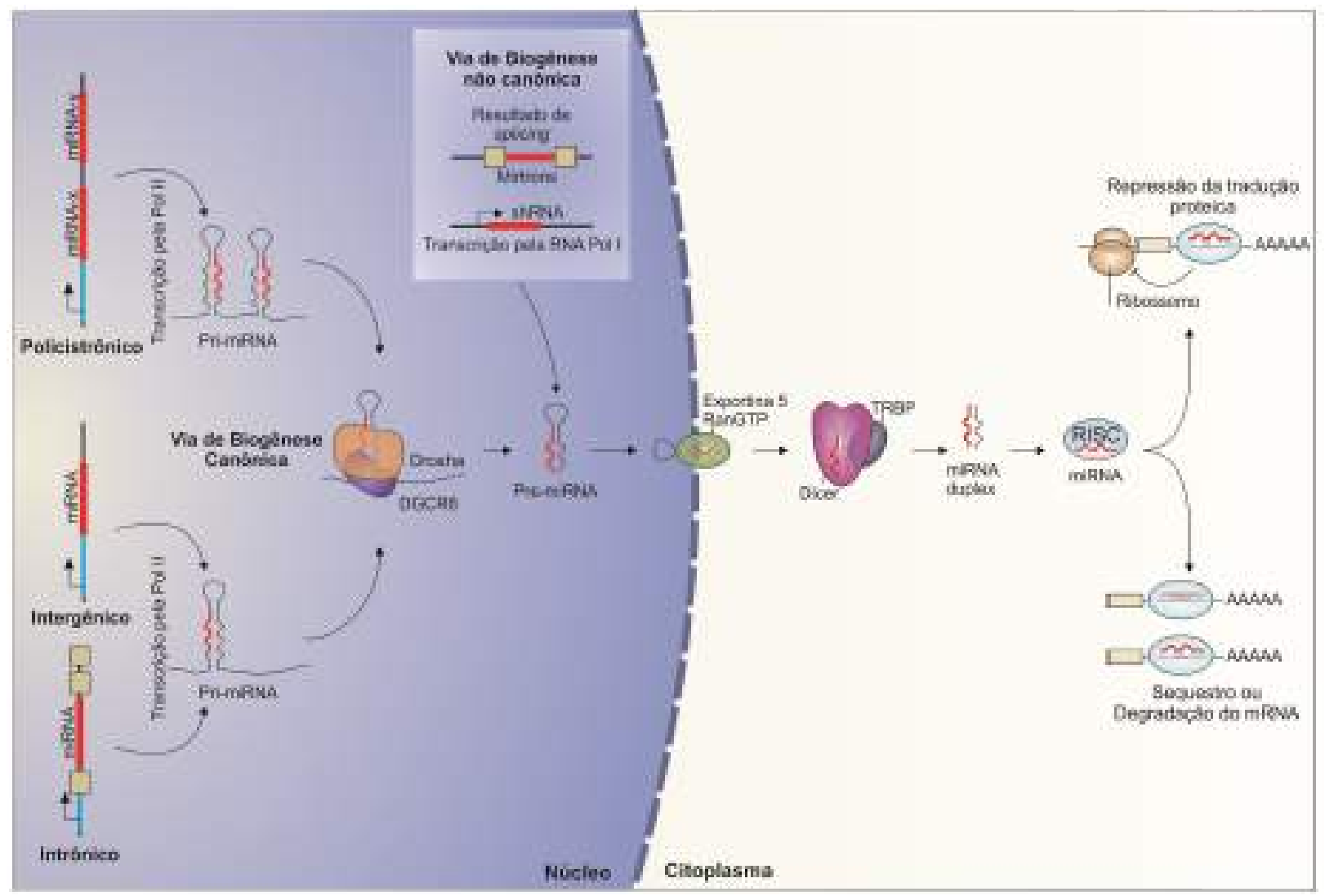

Figura 1. Representação da biogênese dos miRNAs.Da esquerda para a direita, inicialmente são visualizados os genes dos miRNAs no genoma, podendo ser localizados em regiões intrônicas ou intergênicas, e ainda em sequências policistrônicas. Estas sequências são então transcritas em grandes moléculas de RNA denominadas pri-miRNAs, as quais adotam uma conformação secundária por autocomplementariedade de bases. Essas estruturas são reconhecidas pelo complexo Drosha/DGCR8, sendo assim clivadas e dando origem a moléculas de RNA em hairpin conhecidas como pré-miRNAs. Os pré-miRNAs podem se originar também no processamento de mRNAs pelo spliceossomo (Mirtrons) ou de shRNAs endógenos. Por ação da Exportina 5, estas moléculas são transportadas para o citoplasma, onde são processadas pela Dicer, resultando na eliminação da estrutura de hairpin e em uma moléculas de dsRNA. Por atividade das argonautas, essa dupla fita é desfeita, sendo então uma das fitas simples (a fita guia) incorporada ao RISC (complexo de silenciamento induzido por RNA), que passa a ser conhecido como miRISC (complexo de silenciamento induzido por miRNA). A atividade deste complexo se dá pela sua ligação ao mRNA alvo com base na complementariedade entre o miRNA e seu alvo, que pode resultar na repressão da tradução ou degradação do mRNA por clivagem direta ou ainda desestabilização do transcrito por deadenilação. Adaptado de Rottiers e Näär (2012).

Uma vez que o miRISC se liga ao mRNA alvo, a regulação negativa dos níveis proteicos deste pode se dar de três formas: clivagem do mRNA por meio de AGO2 (XU et al., 2016), repressão da tradução ou desestabilização do mRNA por deadenilação (FILIPOWICZ; BHATTACHARYYA; SONENBERG, 2008). A clivagem direta do transcrito ocorre quando há uma extensa complementariedade entre o miRNA e seu alvo, de forma semelhante àquela vista na via de interferência por RNA (RNAi), ocorrendo principalmente em plantas (ACHARD et al., 2004; KASSCHAU et al., 2003; VAUCHERET et al., 2004), mas também em animais (XU et al., 2016). Tanto a repressão da tradução quanto a desestabilização do 
mRNA por deadenilação são mecanismos comuns em animais, sendo este último o mecanismo mais comum, enquanto o primeiro ocorre com menor frequência (FABIAN; SONENBERG; FILIPOWICZ, 2010; HAUSSER et al., 2009; HENDRICKSON et al., 2009; LIM et al., 2005; SIOMI; SIOMI, 2010). São conhecidos alguns casos em que, ao contrário do esperado, os miRNAs regulam positivamente a tradução de seus alvos, levando ao aumento na síntese de proteína destes (ØROM; NIELSEN; LUND, 2008; SHOBHA VASUDEVAN, YINGCHUN TONG, 2007).

A capacidade de se ligar aos seus alvos por complementariedade de bases parcial permite que um único miRNA possa regular até centenas de alvos, sendo verdade também que um mesmo mRNA pode ser alvo de diversos miRNAs (FRIEDMAN et al., 2009; LIM et al., 2005). Essa característica permite que os miRNAs participem dos mais diversos processos celulares e biológicos, regulando diferentes alvos e vias de sinalização, sejam eles em situações patológicas ou não-patológicas.

$\mathrm{Na}$ literatura científica, são encontrados diversos trabalhos associando estes pequenos RNAs reguladores à doenças neurodegenerativas (HE et al., 2017; HÉBERT; DE STROOPER, 2009; KIM et al., 2007; NELSON; WANG; RAJEEV, 2008; RIANCHO et al., 2017; TAGLIAFIERRO et al., 2017), musculares e cardíacas (BITTEL et al., 2014; CARÈ et al., 2007; EISENBERG et al., 2007); e nos mais diferentes tipos de câncer (HAYES; PERUZZI; LAWLER, 2014; JIA et al., 2017; KIM et al., 2017; PAN et al., 2017; ROSENFELD et al., 2008; ZHENG et al., 2017; ZHOU et al., 2017). Nessas situações, os miRNA podem aparecer como figuras importantes na patogênese, manutenção e/ou progressão da doença, biomarcadores para o diagnóstico e prognóstico e como ferramentas para o tratamento, sejam como agentes, alvos ou para elucidar os mecanismos potencialmente moduláveis.

Os diferentes tecidos e tipos celulares possuem um perfil de expressão de miRNAs característico, ao ponto de permitir, por exemplo, a identificação do tecido de origem de uma metástase tumoral por meio de uma análise de expressão de miRNA da amostra (ROSENFELD et al., 2008). Em termos de fenótipo, sabe-se que o que define as características de uma célula (ou de um tecido) é o conjunto de genes expressos nesta somado à influência do ambiente com o qual interage (DUPONT; ARMANT; BRENNER, 2009; SUL et al., 2009; WADDINGTON, 2012). Os miRNAs atuam, neste contexto, orquestrando a tradução dos mRNAs, agindo assim sobre o conjunto de proteínas que será expresso em cada célula e, por fím, na definição do fenótipo celular (ENDO; HAYASHI; SAITO, 2016; ROSENFELD et al., 2008; SOOD et al., 2006). 
A participação dos miRNAs nos mais diversos processos biológicos para a manutenção da vida tem sido amplamente estudada. É sabido que os miRNAs atuam na regulação do ciclo, morte e diferenciação celular, bem como do desenvolvimento dos mais diferentes organismos (BUENO; MALUMBRES, 2011; CARLETON; CLEARY; LINSLEY, 2007; HOUBAVIY; MURRAY; SHARP, 2003; IVEY; SRIVASTAVA, 2010; LÜNINGSCHRÖR et al., 2013; SAYED; ABDELLATIF, 2011; SU et al., 2015; WIENHOLDS; PLASTERK, 2005). Este conjunto de processos está intimamente relacionado a um grupo de células denominadas de células-tronco, as quais serão tratadas no seguinte tópico.

\subsection{Células-Tronco, Pluripotência e Diferenciação Celular}

A observação de que os tecidos são constantemente regenerados durante a vida de um organismo multicelular levou à idealização de um conjunto de células que seria responsável por esta manutenção. Essas células deviam se manter em uma pequena população e possuir a capacidade de proliferar e, ao mesmo tempo, manter o status de indiferenciação, o qual permitiria a reposição de células funcionais no tecido. Com isso, surgiram as primeiras noções sobre células-tronco (LAJTHA, 1979). A capacidade de proliferação e de se manter indiferenciada, juntamente à habilidade de dar origem a um ou mais tipos celulares, compreendem as características básicas de uma célula-tronco, que podem ser encontradas no corpo humano em diferentes estágios da vida (BEHR et al., 2010).

Uma importante característica destas células é o seu potencial de diferenciação. Desta forma, elas podem ser classificadas como totipotentes, pluripotentes, multipotentes, oligopotentes e unipotentes, sendo totipotentes aquelas com maior potencial de diferenciação e unipotentes, com um menor potencial (KOLIOS; MOODLEY, 2013). Do ponto de vista da medicina regenerativa, as células-tronco pluripotentes atraíram a atenção dos pesquisadores, pela capacidade de originar praticamente todos os tipos celulares de um organismo adulto, incluindo aquelas da linhagem germinativa (DE MIGUEL; FUENTES-JULIÁN; ALCAINA, 2010; GASPAR-MAIA et al., 2011; MIMEAULT; HAUKE; BATRA, 2007; ZHOU et al., 2016).

De forma natural, em humanos, as células-tronco pluripotentes ocorrem nas seguintes circunstâncias: durante o desenvolvimento embrionário, sendo encontradas na massa celular interna do blastocisto; ou em tumores de células germinativas conhecidos como teratocarcinomas (ANDREWS, 2002; BARBARIC; HARRISON, 2012). De fato, as primeiras 
células pluripotentes cultivadas foram aquelas derivadas de teratocarcinomas. Essas células, conhecidas como células de carcinoma embrionário (CCE), são responsáveis por conferir o status maligno a este tumor, diferenciando-o do teratoma, que é formado somente por células e tecidos bem diferenciados dos três folhetos embrionários, não sendo capaz de gerar metástases por não possuir células-tronco tumorais (BARBARIC; HARRISON, 2012; MARTIN; EVANS, 1974).

Pesquisadores descobriram que, em modelos animais, ao se transferir embriões nas fases iniciais de desenvolvimento para outros tecidos ou órgãos, que não o útero pronto para recebê-los, ocorria o desenvolvimento de teratocarcinomas (SOLTER; DOMINIS; DAMJANOV, 1979; SOLTER; SKREB; DAMJANOV, 1970). Essa seria uma forma alternativa de se obter as $\mathrm{CCE}$ e, com o cultivo dessas células in vitro e a geração de diferentes linhagens celulares de CCE, tornou-se possível a utilização dessas no estudo da pluripotência e da diferenciação celular (FINCH; EPHRUSSI, 1967; KAHAN; EPHRUSSI, 1970; MARTIN; EVANS, 1974).

O uso dessas células nos mais diferentes experimentos para caracterizá-las, bem como para entender como estavam relacionadas com as células pluripotentes no embrião, levou ao isolamento e cultivo in vitro das primeiras células-tronco embrionárias (CTE). Nesta ocasião, foram obtidas células da massa celular interna de blastocistos murinos, as quais foram cultivadas com um meio de cultura condicionado por CCE e sobre uma camada de células feeder inativadas com mitomicina C (MARTIN, 1981).

De fato, diversas características são compartilhadas entre as CCE e as CTE, assim como muitos dos marcadores fenotípicos inicialmente identificados nas CCE são utilizados até o presente momento como marcadores de pluripotência, presentes também nas CTE. Essa similaridade faz das CCE bons modelos experimentais para estudos in vitro sobre a pluripotência e a diferenciação celular, uma vez que o cultivo de CTE, principalmente das humanas, apresentam um elevado custo e complexidade (ANDREWS et al., 1982, 1984a, 1984b; BADCOCK et al., 1999; DRAPER et al., 2002; GREBER; LEHRACH; ADJAYE, 2007; STEWART et al., 2008).

Somente em 1998 foram publicados os primeiros trabalhos demonstrando a obtenção de CTE humanas (CTEh) (SHAMBLOTT et al., 1998; THOMSON et al., 1998), após terem sido cultivadas por longos períodos in vitro sem perder as características de pluripotência, incluindo a expressão de marcadores conhecidos e a capacidade de originar células dos três folhetos embrionários. Esse avanço guiou o estudo da pluripotência a uma nova era, na qual 
os mecanismos envolvidos no controle das características intrínsecas das células-tronco passaram a ser mais profundamente explorados.

Antes mesmo do isolamento de CTE, pesquisadores já buscavam entender as bases moleculares envolvidas com o potencial de diferenciação das células que davam origem a um organismo multicelular, bem com o mecanismo por detrás da reprogramação que ocorria para que células diferenciadas (os gametas) pudessem originar células totipotentes. $O$ trabalho de Briggs e King (1952) teve como objetivo desenvolver uma técnica de transferência nuclear para estudar o papel do núcleo durante a diferenciação celular, para isso os pesquisadores utilizaram oócitos de sapos, os quais foram primeiramente enucleados e em seguida receberam o núcleo de blástulas. Após a transferência do núcleo, as células resultantes continuaram o processo embriológico normalmente. Em 1962 foi a vez de outro estudo dar um grande salto para a biologia das células-tronco, pois, por meio da técnica de transferência nuclear, também em sapos, foram utilizados núcleos de células terminalmente diferenciadas, obtidas do intestino de animais adultos, na transferência para oócitos enucleado, que resultou na reprogramassão dos núcleos somáticos e no prosseguimento dos processos de embriogênese normal, gerando por fim indivíduos saudáveis (GURDON, 1962). Esse achado acresentou uma informação de grande importância que foi a existência de um fator (ou um conjunto de fatores) no citoplasma dos oócitos capaz(es) de apagar o "programa" nuclear, permitindo assim que o núcleo retomasse a capacidade de reger a diferenciação celular para os diferentes tipos de células de um indivíduo adulto.

O trabalho de Blau e colaboradores (1983) demonstrou em células de mamíferos, por meio do uso de heterocárions, que o fenótipo celular pode ser modulado por fatores controlados pelo núcleo, mas presentes no citoplasma. Outros trabalhos levaram a identificação de fatores de transcrição que ficaram conhecidos como "reguladores mestres", os quais eram capazes de controlar o destino celular, sendo que a expressão ectópica de um destes fatores de transcrição era capaz de alterar a diferenciação normal de uma célula (ou de um conjunto de células) para outra de um tecido completamente diferente (DAVIS; WEINTRAUB; LASSAR, 1987; SCHNEUWLY; KLEMENZ; GEHRING, 1987). Já em 1997, além do relato do primeiro clone de mamífero originado por transferência nuclear (WILMUT et al., 1997), a ovelha Dolly, também foi publicado um trabalho que demonstrava que as CTE tinham o potencial de reprogramar núcleos de células diferenciadas, de forma similar ao que se via na transferência nuclear para oócitos enucleados (TADA et al., 1997). O conjunto destas informações, somados aos resultados obtidos por Gurdon (1962), levaram a crer que os fatores responsáveis pela reprogramação do núcleo somático para um estado 
indiferenciado poderiam agir como "reguladores mestres", sendo que a expressão ectópica destes em células teminalmente diferenciadas faria com que estas retomassem o estado de uma célula-tronco pluripotente.

Com esta ideia em mente, pesquisadores selecionaram genes que foram identificados como altamente expressos em células pluripotentes e realizaram a expressão destes (separadamente e em conjuntos) em fibroblastos de mamíferos, com o uso de vetores virais. Como resultado, chegaram a um conjunto mínimo de quatro fatores (OCT4, KLF4, SOX2 e MYC, ou OKSM), os quais ficaram conhecidos como fatores de Yamanaka, que, quando expressos em células diferenciadas, agiam induzindo uma reprogramação nuclear, induzindo assim um fenótipo pluripotente nestas células, de forma que passaram a ser conhecidas como células-tronco pluripotentes induzidas (iPSC, induced pluripotent stem cells) (TAKAHASHI; YAMANAKA, 2006).

Com o advento dessas células, uma novo passo foi dado no campo de estudo das células-tronco, pois essa metodologia permitiria contornar os problemas éticos envolvidos no uso de CTE, já que não seria necessária a destruição de um embrião para a obtenção de células pluripotentes, e essas células poderiam ser paciente-específicas, evitando problemas de histocompatibilidade, assim como aquelas da proposta clonagem terapêutica. Essas células também surgiram como importantes ferramentas no estudo do desenvolvimento embrionário, de doenças genéticas e para indústria farmacêutica, como fonte de modelos celulares para os mais diversos tipos de patologias (SHI et al., 2017; SINGH et al., 2015; STADTFELD; HOCHEDLINGER, 2010). Na Figura 2 se encontra um esquema que demonstra de forma resumida as possíveis aplicações das iPSC. 


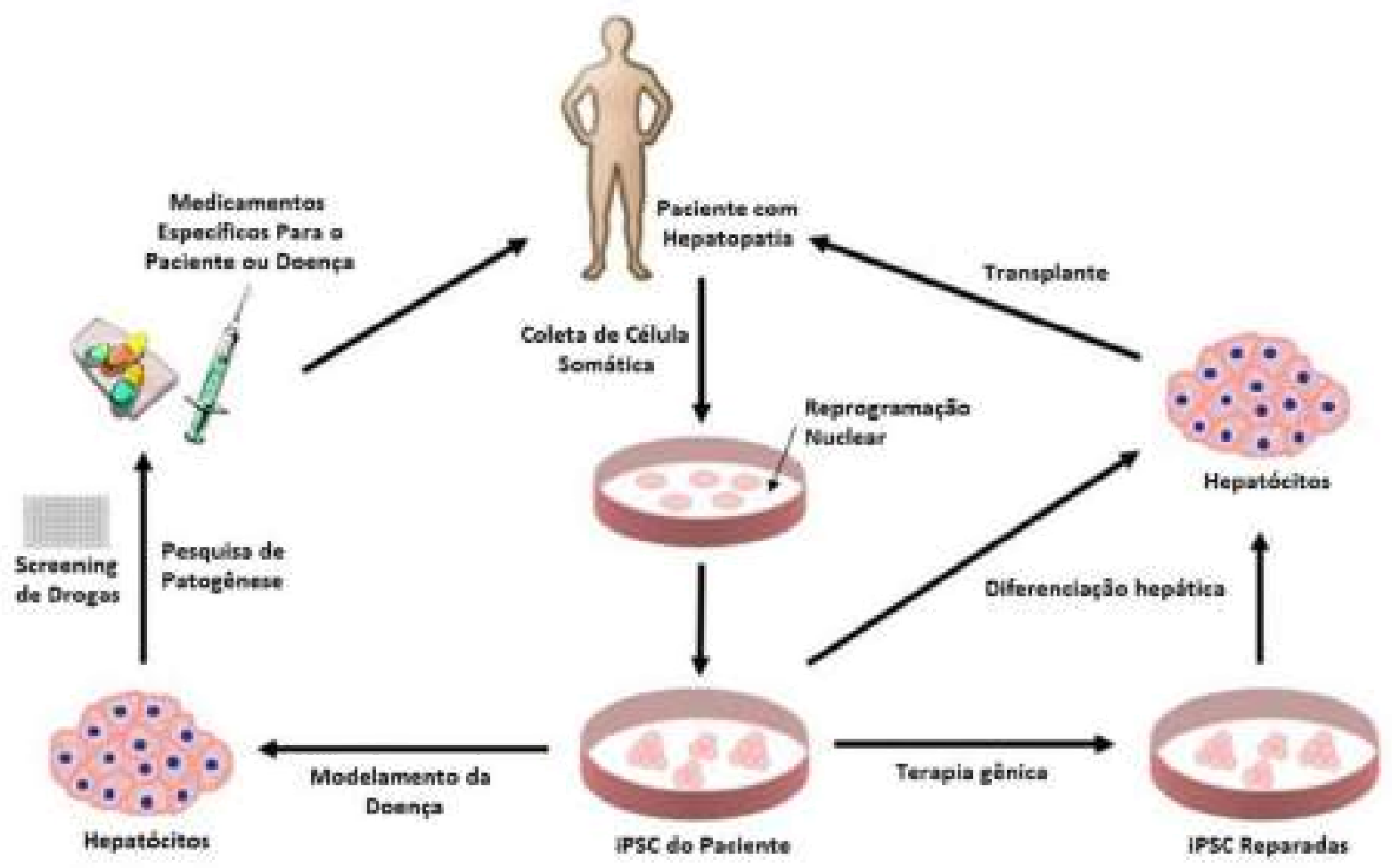

Figura 2. Possíveis aplicações práticas das células-tronco pluripontentes induzidas (iPSC).Um indivíduo pode fornecer células somáticas as quais serão reprogramadas, propagadas in vitro e, posteriormente, aplicadas para medicina regeneratica e personalisada, no desenvolvimento de drogas ou, ainda, no modelamento de doenças. Como exemplo, as iPSC podem ser diferenciadas em células específicas saudáveis (uso de terapia gênica, por exemplo) e reimplatadas no paciente. Ainda, essas células podem ser usadas para screening de drogas, com a finalidade de se desenvolver fármacos para uma doença específica ou para identificação de medicamentos que apresentem maior eficácia no tratamento de uma patologia, podendo ter sua eficiência testada para um paciente específico (medicina personalizada). Adaptado de Chun e colaboradores (2010).

Com a possibilidade de se cultivar células pluripotentes humanas, agora incluindo também as iPSC, aprofundaram-se os estudos sobre as vias de sinalização envolvidas na regulação do fenótipo pluripotente, bem como dos mecanismos que controlam a rede gênica responsável pelas características das células-tronco e que orquestram a diferenciação e a definição do destino celular. A Figura 3, obtida da base de dados KEGG PATHWAY, apresenta um resumo de algumas das vias de sinalização conhecidamente envolvidas na regulação do fenótipo pluripotente, dando destaque às vias JAK-STAT, MAPK, PI3K-AKT, TGF $\beta$ e WNT.

Sabe-se que, em murinos, a presença de LIF no meio de cultura de CTE é de crucial importância para a manutenção do status pluripotente, já que, ao se ligar com o seu receptor LIFR e induzir a formação de um heterodímero com o receptor de transdução de sinal gp130, desencadeia uma série de reações que promovem o fenótipo pluripotente, como a fosforilação de JAK, que leva a ativação de STAT3 (HUMPHREY et al., 2004; NICHOLS; CHAMBERS; SMITH, 1994; YOSHIDA et al., 1994). Já em células humanas, a atividade de LIF não é 
essencial para a manutenção da pluripotência, já que o LIF liberado pelas células alimentadoras (MEF, mouse embryonic fibroblasts), bem como IL6, não exerce nenhuma atividade sobre os receptores apresentados pelas CTEh. Mesmo a adição de LIF humano em meios de cultura para CTE não foi capaz de manter a pluripotência destas células e outros estudos ainda demonstraram que a ativação de STAT3 em CTEh não é essencial para que essas células mantenham seu fenótipo (HUMPHREY et al., 2004; REUBINOFF et al., 2000; THOMSON et al., 1998).

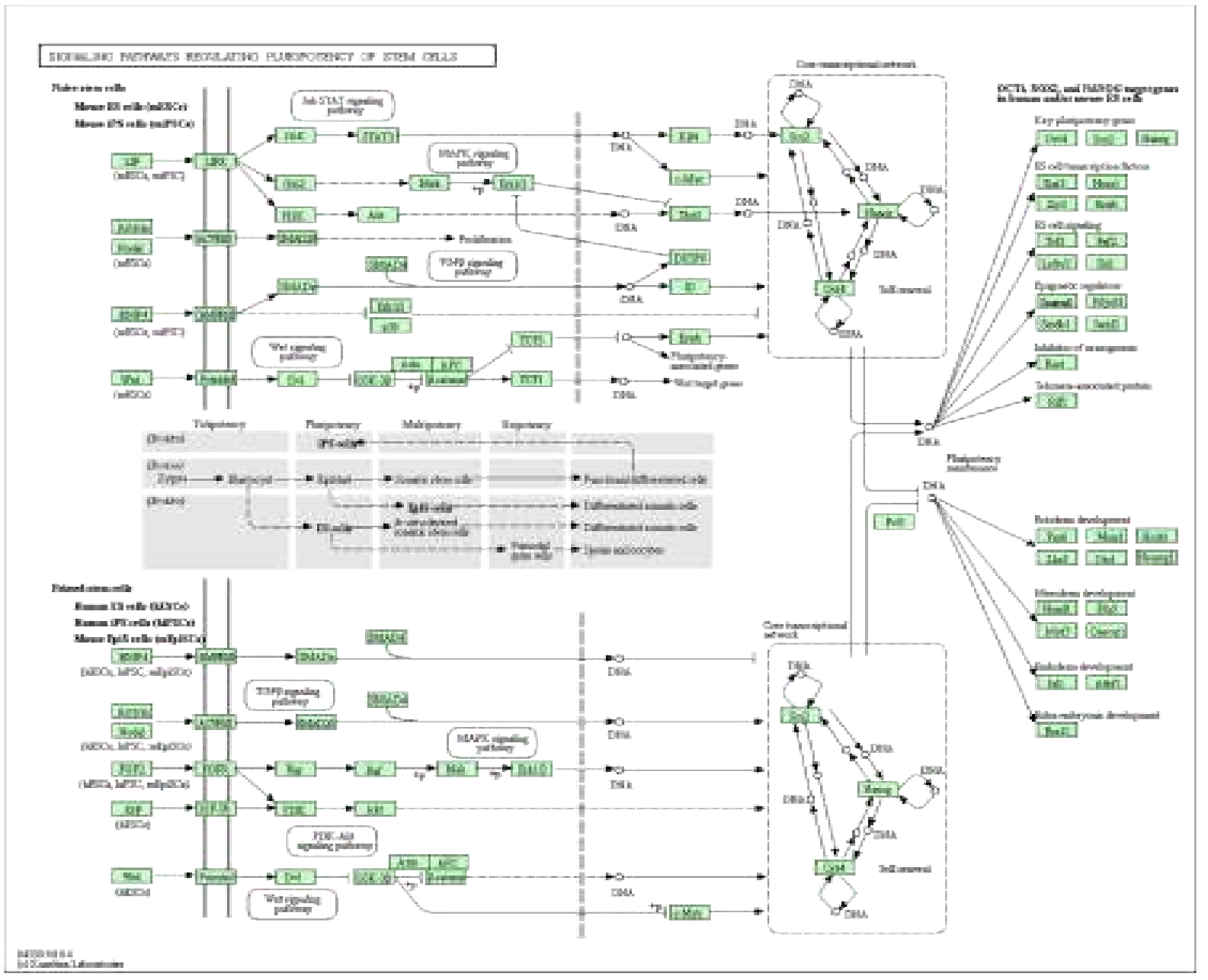

Figura 3. Esquematização de algumas das principais vias de sinalização envolvidas na regulação da rede gênica que promove as características de pluripotência em células-tronco embrionárias murinas e humanas. Essas vias agem sobre o metabolismo dasa células-tronco embrionárias, bem como sobre a rede gênica que regula tanto o fenótipo pluripotente, quanto a diferenciação e determinação do destino celular.

No contexo da pluripotência, a via das MAPK tem um papel importante na diferenciação celular, agindo por meio de ERK, JNK e p38MAPK para, em conjunto com outros fatores, guiar as células pluripotentes aos seus destinos finais, como células terminalmente diferenciadas e com funções definidas nos tecidos adultos (ARMSTRONG et 
al., 2006; BINÉTRUY et al., 2007; HAMILTON; BRICKMAN, 2014). A via do TGF $\beta$, por sua vez, apresenta um papel ambíguo em CTE, pois alguns dos seus componentes demonstram atividades pró-pluripotência, inibindo a atividade de ERK e p38MAPK, enquanto outros podem promover a transição epitelial-mesenquimal (EMT, epithelialmesenchymal transition), evento necessário para a diferenciação de células pluripotentes (PARK, 2011). Sabe-se que, durante a reprogramação nuclear, o uso de inibidores de TGF $\beta$ promove a expressão de NANOG, resultando numa melhora na eficiência da geração de iPSC (MAHERALI; HOCHEDLINGER, 2009).

A via de PI3K-AKT está envolvida com a manutenção do fenótipo pluripotente pela sua participação nos processos metabólicos dessas células, que utiliza a glicólise anaeróbica como fonte de energia, sendo que o desenvolvimento embrionário se dá num ambiente de hipóxia, em condições fisiológicas (OTTOSEN et al., 2006). De fato, a mudança de um metabolismo baseado na fosforilação oxidativa para uma via glicolítica faz parte do processo de reprogramação celular, sendo que AKT age como ativador de reguladores da glicólise e a ativação dessa via de sinalização resulta na otimização do processo de reprogramação nuclear (CHEN et al., 2012b; HOSSINI et al., 2016; PANOPOULOS et al., 2012; ZHU et al., 2010).

Outra via concernente à pluripotência e à diferenciação celular é a via de sinalização de WNT. A compreensão da relação entre a ativação de WNT e a regulação pós-traducional sobre a estabilidade da $\beta$-catenina é de extrema importância para o entendimento da via, já que após a ativação da via, ocorre um acumulo de $\beta$-catenina no núcleo, que por sua vez interage com TCF e LEF, promovendo a modulação na expressão gênica dependente do contexto celular ou tecidual (MOON, 2005). Muitos estudos presentes na literatura indicam que a sinalização de WNT via $\beta$-catenina participa na manutenção do fenótipo pluripotente de CTE, tanto humanas como murinas, sendo que alguns deles demonstraram que esta via pode também participar na promoção da pluripotência durante a reprogramação nuclear (BERGE et al., 2011; MARSON et al., 2008b; MIYABAYASHI et al., 2007; SATO et al., 2004). Do mesmo modo, também é descrito que a a participação desta via é importante para o potencial de diferenciação das células pluripotentes, porém sua atividade é dispensável para a autorrenovação celular e, pelo contrário do esperado, é reprimida por OCT4 em CTEh, sendo que a ativação desta conduz a perda das características de pluripotência nestas células (DAVIDSON et al., 2012; LYASHENKO et al., 2011).

No contexto da diferenciação de células pluripotentes, a via Notch tem sido descrita como uma participante ativa, contribuindo para origem de diversos tipos celulares durante o desenvolvimento embrionário, sendo reportada sua atividade em culturas de CTEh sob 
diferenciação celular, mas não naquelas que apresentam características de pluripotência(KOBAYASHI et al., 2009; YU et al., 2008). Um dos mecanismos envolvidos nessa participação de Notch para o desencadeamento da diferenciação celular se dá via HES1, já que foram observadas oscilações na expressão deste gene em CTE, e diferentes dosagens deste gene podem influenciar no destino celular (KOBAYASHI; KAGEYAMA, 2010). Adicionalmente a isto, foi identificado que a expressão de Gadd45a e Gadd45b (regulados por um componente da via Notch) é crítica para a embriogênese em sapos do gênero Xenopus, participando da inibição da pluripotência e subsequente início da diferenciação celular das CTE nestes animais (KAUFMANN; NIEHRS, 2011).

Por fim, todas essas vias acabam agindo ou interferindo na regulação da rede gênica exercida por um conjunto central de fatores de transcrição: OCT4, SOX2 e NANOG. Essas três proteínas regem a expressão de genes que mantém o fenótipo pluripotente em CTE, tanto em camundongos como em humanos (CHAMBERS; TOMLINSON, 2009). Além de compartilharem diversos alvos e se corregularem, OCT4 e SOX2 interagem entre si para agirem como reguladores da expressão gênica em células pluripotentes, sendo a inibição desta interação envolvida em processos como a transição epitelial-mesenquimal (EMT; epithelialmesenchymal transition) e a diferenciação celular em CTE (CHEW et al., 2006; JERABEK et al., 2014; PAN et al., 2016). A regulação fina nos níveis destes fatores de transcrição é de grande importância para a manutenção do status pluripotente, já que, por exemplo, a superexpressão de OCT4 pode levar a diferenciação celular. A perda da expressão de OCT4 ou SOX2 também podem levar ao mesmo destino, embora que a perda superexpressão de OCT4 supra a ausência de SOX2. Essas informações levam a um melhor entendimento dos mecanismos envoltos na corregulação exercida entre os fatores centrais da pluripotência. (CHAMBERS; TOMLINSON, 2009; KUNATH; STRUMPF; ROSSANT, 2004; MASUI et al., 2007; NIWA; MIYAZAKI; SMITH, 2000).

No que se refere ao $N A N O G$, sabe-se que seu papel é fundamental para o desenvolvimento em mamíferos, agindo em conjunto com os demais fatores essenciais para a manutenção da pluripotência (CHAMBERS et al., 2003; MITSUI et al., 2003), mesmo que a expressão deste não seja indispensável para a indução da reprogramação nuclear (TAKAHASHI; YAMANAKA, 2006). O surgimento da expressão de NANOG, no curso do desenvolvimento embrionário, se dá justamente no conjunto de células que possuem o fenótipo pluripotente, diferentemente de OCT4 e SOX2, que são expressos em fases bem iniciais, em todos os blastômeros (AVILION et al., 2003; PALMIERI et al., 1994; RODDA et al., 2005). Essas proteínas também participam da regulação da expressão de NANOG, mas 
este, por sua vez, tem um nível proteico bastante flutuante em células pluripotentes, o que não ocorre com os níveis de OCT4 e SOX2 (CHAMBERS et al., 2007; RODDA et al., 2005). Esse fenômeno pode ser explicado, por exemplo, pela propriedade autorregulatória de NANOG, que ao interagir com diferentes reguladores transcricionais, pode induzir ou reprimir a transcrição de seu próprio gene (FIDALGO et al., 2012; LIANG et al., 2008; LIM et al., 2010; LOH et al., 2006).

Como pôde ser visto, o controle de toda a rede gênica envolvida com o fenótipo pluripotente precisa ser muito bem orquestrado, já que tanto a presença ou ausência de uma proteína, como variações nas concentrações destas, podem influenciar nas características e destino das CTE. Desta maneira, é esperado que os miRNAs desenvolvam papéis importantes na regulação da expressão gênica destas células com características fenotípicas tão peculiares (IVEY; SRIVASTAVA, 2010; WANG et al., 2009). Alguns miRNAs são regulados diretamente pelos fatores de pluripotência, e a participação destes pequenos reguladores nos mecanismos ligados à pluripotência, diferenciação e reprogramação é já foram descritos por alguns grupos de pesquisa (BERARDI et al., 2012; CARD et al., 2008; LICHNER et al., 2011; TAY et al., 2008; XU et al., 2009). Além disso, diversos miRNAs foram identificados como diferencialmente expressos em células pluripotentes e em diferenciação (STADLER et al., 2010). Entretando, o papel dos miRNAs na biologia das CTE, bem como os possíveis mecanismos envolvidos na modulação do fenótipo, são estudados em pequenas escalas e, até o momento, não foram descritas abordagens que correlacionem os efeitos dos miRNAs em células pluripotentes humanas e as vias pelas quais estes podem regular tanto a manutenção da pluripotência, bem como a diferenciação celular.

\subsection{High Content Analysis/Screening}

Ao se estudar a resposta celular frente a um determinado ambiente, estímulo ou tratamento, a observação das alterações fenotípicas a nível celular pode oferecer informações de grande valor. Assim, a abordagem de High Content Analysis/Screening (HCA/S) se torna uma ferramenta poderosa para pesquisas relacionadas à biologia celular e mecanismos moleculares envolvidos nos mais diferentes fenômenos, já que é baseada na aquisição automatizada de imagens de células por microscopia de luz em placas de cultura celular, acoplada ao uso de softwares que permitem uma avaliação a nível de célula de características morfológicas e/ou imunofenotípicas, possibilitando a obtenção de um elevado número de informações (TAYLOR, 2007). 
Em comparação aos ensaios de quantificação de luminescência, absorbância ou fluorecência, os quais muitas vezes limitam-se a poucos parâmetros analisados, além de não levarem em consideração as características morfológicas celulares e heterogeneidade da população celular analisada, a abordagem de HCS se mostra superior, pois a combinação de marcadores fluorescentes específicos para proteínas, estruturas ou compartimentos celulares oferecem, além das informações sobre as células como um todo, também dados sobre a localização do objeto observado. A variação nas intensidades de fluorescência das marcações podem ser reflexos das quantidades de um determinado alvo de estudo, sendo que, após a análise das imagens, são obtidos dados quantitativos, os quais podem ser submetidos a testes estatísticos com menor influência do observador (BOUTROS; HEIGWER; LAUFER, 2015; XIA; WONG, 2012).

Esta abordagem tem sido amplamente utilizada para as mais diversas finalidades, como, por exemplo, na identificação de novos tratamentos para o câncer, infecções por microorganismos ou de doenças cardiovasculares (EULALIO et al., 2012; LOVE et al., 2017; MANNING et al., 2017; PASCOALINO et al., 2016; SONG et al., 2017). Em outro exemplo, um grupo da Coréia do Sul realizou um screening com uma biblioteca de compostos químicos em CTEh, com o intuito de identificar compostos que poderiam induzir estados iniciais de diferenciação. Como parâmetro para avaliação do status de diferenciação das culturas de células, foi utilizada a imunomarcação de OCT4, sendo utilizada a intensidade de fluorescência desta marcação para identificar os tratamentos capazes de modular a pluripotência nestas células (JEE et al., 2012). Algo comum a estes trabalhos foi a avaliação de somente um ou poucos parâmetros morfofenotípicos, não utilizando muitas vezes todo o potencial do $\mathrm{HCA} / \mathrm{S}$.

Uma vez que se analisa um grande número de células de forma individual dentro de um grupo de tratamento, os dados gerados para os mais diferentes parâmetros (que podem chegar de dezenas a centenas), quando agrupados, montam o que pode ser chamado de perfil fenotípico multiparamétrico. Esse tipo de informação pode ser utilizado, por exemplo, para a dedução de mecanismos de ação de compostos testados sobre um tipo celular, num determinado contexto, comparando-se o perfil fenotípico gerado por um tratamento "desconhecido" com um de referência, onde as alterações fenotípicas e os mecanismos moleculares envolvidos nela são bem conhecidos (BICKLE, 2010; SUNDARAMURTHY et al., 2014). Desta maneira, a hipótese central do presente estudo é a de que a avaliação e identificação de miRNAs com efeitos fenotípicos similares sobre células pluripotentes, 
associado à determinação de alvos preditos compartilhados por eles, permitirá a identificação de vias de sinalização relevantes no contexto da pluripotência e da diferenciação celular. 
2. ObJetivos 


\subsection{Objetivo geral}

Identificar vias e alvos potencialmente modulados por grupos de microRNAs com efeitos fenotípicos similares, no contexto da pluripotência e da diferenciação, utilizando uma abordagem de High Content Analysis (HCA), baseada na análise celular quantitativa multiparamétrica por microscopia automatizada.

\subsection{Objetivos específicos}

- Estabelecer um ensaio de HCA capaz de permitir a avaliação quantitativa de características fenotípicas celulares associadas à manutenção da pluripotência e à diferenciação em células pluripotentes humanas;

- Avaliar os efeitos fenotípicos de um conjunto de microRNAs, diferencialmente expressos entre células pluripotentes e induzidas à diferenciação, utilizando o ensaio de HCS estabelecido;

- Identificar grupos de microRNAs que tenham induzido perfis fenotípicos multiparamétricos similares;

- Identificar transcritos-alvos preditos comuns aos microRNAs de um mesmo grupo e, com base nestes conjuntos de alvos, identificar vias de sinalização potencialmente moduladas pelos microRNAs, que sejam relevantes no contexto da pluripotência e diferenciação celular;

- Validar alvos de microRNAs, bem como os mecanismos identificados. 
3. Metodologia 


\subsection{Linhagens celulares e condições de cultivo}

Para o desenvolvimento do presente trabalho, foram utilizadas duas linhagens celulares pluripotentes de humanos: a linhagem NTera-2 Cl.D1, um clone da linhagem Tera2, a qual foi originalmente derivada de células de metástases pulmonares de um carcinoma embrionário testicular humano xenotransplantado em camundongo (ANDREWS, 1984) (Figura 4A); linhagem H1 de células-tronco embrionárias (também conhecida como WA01), sendo esta uma das primeiras linhagens de CTEh estabelecidas (THOMSON et al., 1998) (Figura 4B). Ambas portam cromossomos XY.
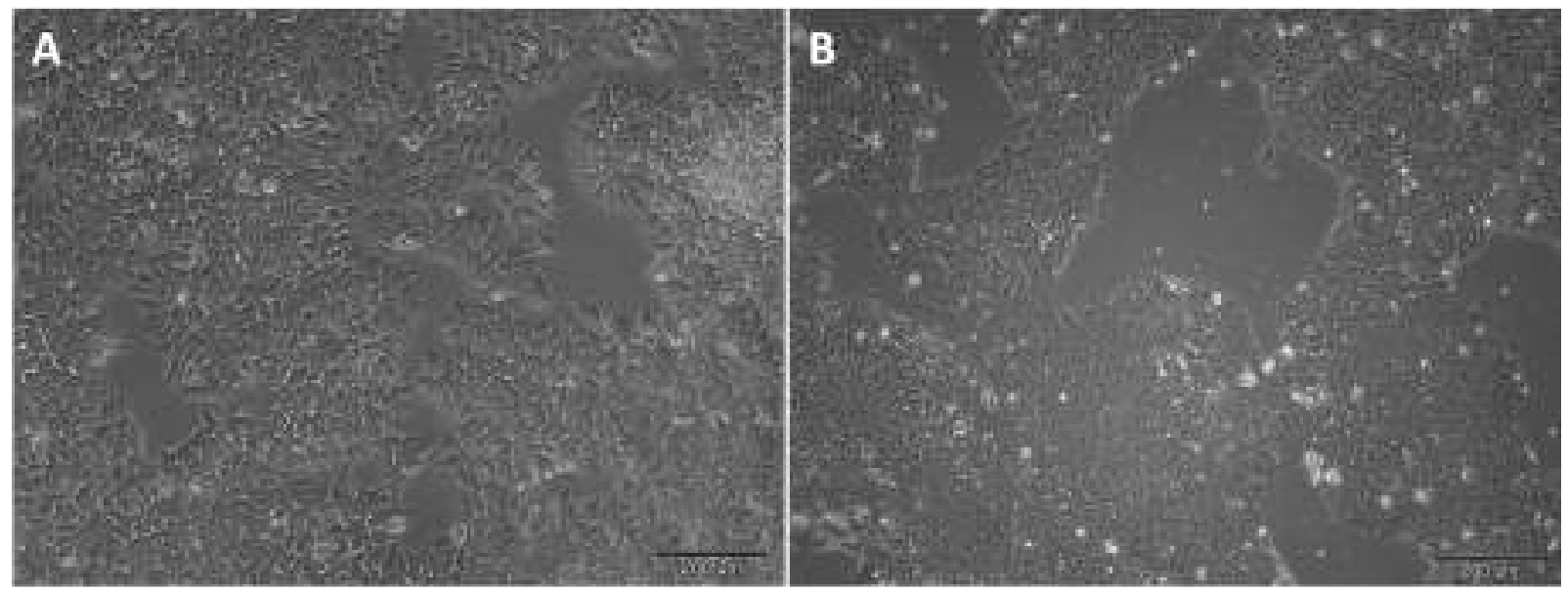

Figura 4. Fotomicrografias de células das linhagens NTera-2 (A) e H1 (B) realizadas em microscópio invertido com contraste de fase. É visível o aspecto epitelial de ambas as linhagens celulares, com células justapostas e pouco alongadas. Percebe-se ainda que as células da linhagem NTera-2 são maiores e é de fácil identificação os limites entre uma célula e outra.

A linhagem NTera-2 foi obtida do Banco de Células do Rio de Janeiro (BCRJ) e cultivada em DMEM (Dulbecco's Modified Eagle's Medium high glucose, Gibco, \#12800017), suplementado com 10\% de soro fetal bovino (SFB, GE Life Sciences, \#SH30071.03), em frascos de cultura de 25,75 ou $175 \mathrm{~cm}^{2}$ de área de crescimento. Para a manutenção da cultura, o meio foi trocado a cada dois dias e o repique realizado quando as culturas alcançavam uma densidade celular por volta de $85 \%$, de forma mecânica, utilizando-se cell scrapers. Para criopreservação, $3 \times 10^{6}$ células são congeladas em solução de congelamento própria, composta de 70\% high glucose DMEM, 20\% soro fetal bovino (SFB) e 10\% DMSO (Dimetilsufóxido, Sigma-Aldrich, \#D-5879) e estocadas em nitrogênio líquido $\left(-196^{\circ} \mathrm{C}\right)$.

A linhagem H1 foi cedida pelo Laboratório de Terapia Celular do Hemocentro de Ribeirão Preto (originalmente obtida do banco banco WiCell - ID: WA01, www.wicell.org; hPSCReg ID: WAe001-A, https://hpscreg.eu). Para o presente estudo, essas células foram cultivadas em condição feeder free (cultivo livre de células "alimentadoras" - MEFs [mouse 
embryonic fibroblasts]), utilizando-se a matriz GelTrex ${ }^{\circledR}$ (Gibco, \#A1413302) e o meio de cultura mTeSR ${ }^{\mathrm{TM}} 1$ (STEMCELL Technologies, \#5850), em placas de 6 poços. Além disso, foi realizada previamente uma adaptação de crescimento em monocamada, já que culturas de células-tronco embrionárias geralmente são realizadas em colônias e, dessa forma, a análise quantitativa das imagens poderia ser prejudicada. A esse método de cultivo é dado o nome de crescimento em monocamada do tipo não-colônia (NCM, non-colony type monolayer growth). Para manutenção das células, o meio de cultura foi trocado diariamente e o repique enzimático (utilizando a enzima StemPro ${ }^{\circledR}$ Accutase ${ }^{\circledR}$ Cell Dissociation Reagent, Thermo Fisher Scientific) foi realizado quando atingida a densidade celular de 100\%. Para inibir a diferenciação espontânea por se encontrarem em células únicas, como resultado do repique enzimático, foi utilizado um inibidor de Rho-cinases (ROCK1/2) (Cloridrato Y-27632,

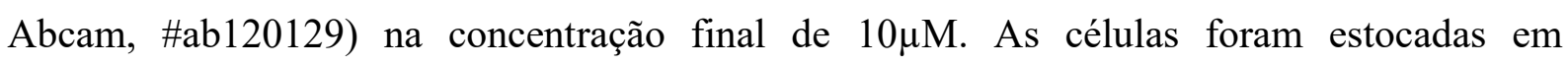
nitrogênio líquido em solução de congelamento, composta de mTeSR $^{\mathrm{TM}} 1$, inibidor de ROCK $(10 \mu \mathrm{M})$ e $10 \%$ de DMSO.

Ambas as linhagens celulares foram mantidas em incubadora umidificada, com umidade relativa do ar $(85 \%)$, temperatura $\left(37^{\circ} \mathrm{C}\right)$ e concentração de $\mathrm{CO}_{2}(5 \%)$ controladas. Essas linhagens apresentaram resultado negativo no teste para contaminação com micoplasma (MycoAlert $^{\mathrm{TM}}$ Mycoplasma Detection Kit, Lonza, \#LT07), e foram investigadas , por microscopia de imunofluorescência, quanto à expressão de marcadores de pluripotência conhecidos: OCT4 (anti-OCT4, Santa Cruz Biotechnology, \#sc-9081), SOX-2 (anti-SOX-2, Santa Cruz Biotechnolody, \#sc-365823), TRA-1-81 (anti-TRA-1-81, Santa Cruz Biotechnology, \#sc-21706) (Figura 5).

Dois diferentes clones derivados da linhagem OP9, que consiste de células estromais da medula óssea de camundongos, foram utilizados em uma etapa de validação funcional da ação de miRNAs sobre a via Notch para promoção de pluripotência. Esses clones foram originados da transformação de células O9 com um vetor vazio (OP9-controle, ctrl) ou expressando um indutor da via Notch, o DLL-1 (OP9-DL1). Essas células foram cultivadas em $\alpha$-MEM (Gibco, \#11900-024), contendo 20\% de SFB. Para a manutenção da cultura, o meio foi trocado a cada dois ou três dias, sendo o repique destas, quando necessário, realizado

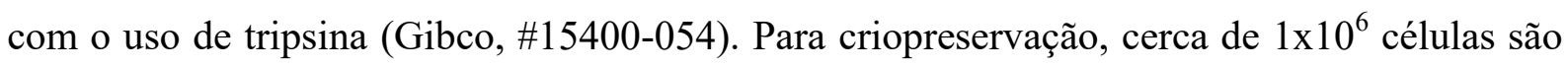
suspendidas em uma solução de SFB contendo $10 \%$ de DMSO e mantidas em nitrogênio líquido por tempo indefinido. 
Linhagem $\mathrm{H} 1$

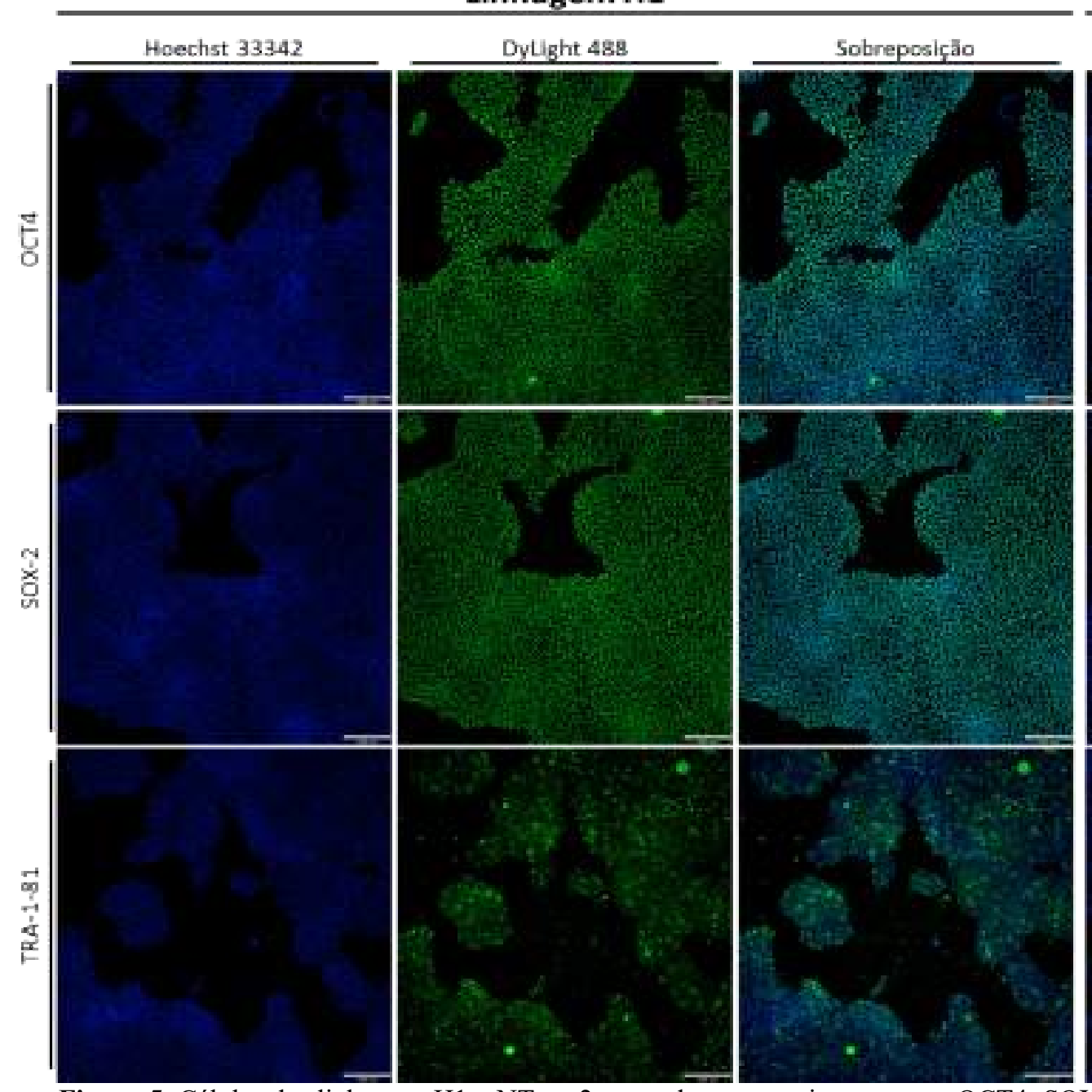

Linhagem NTera-2

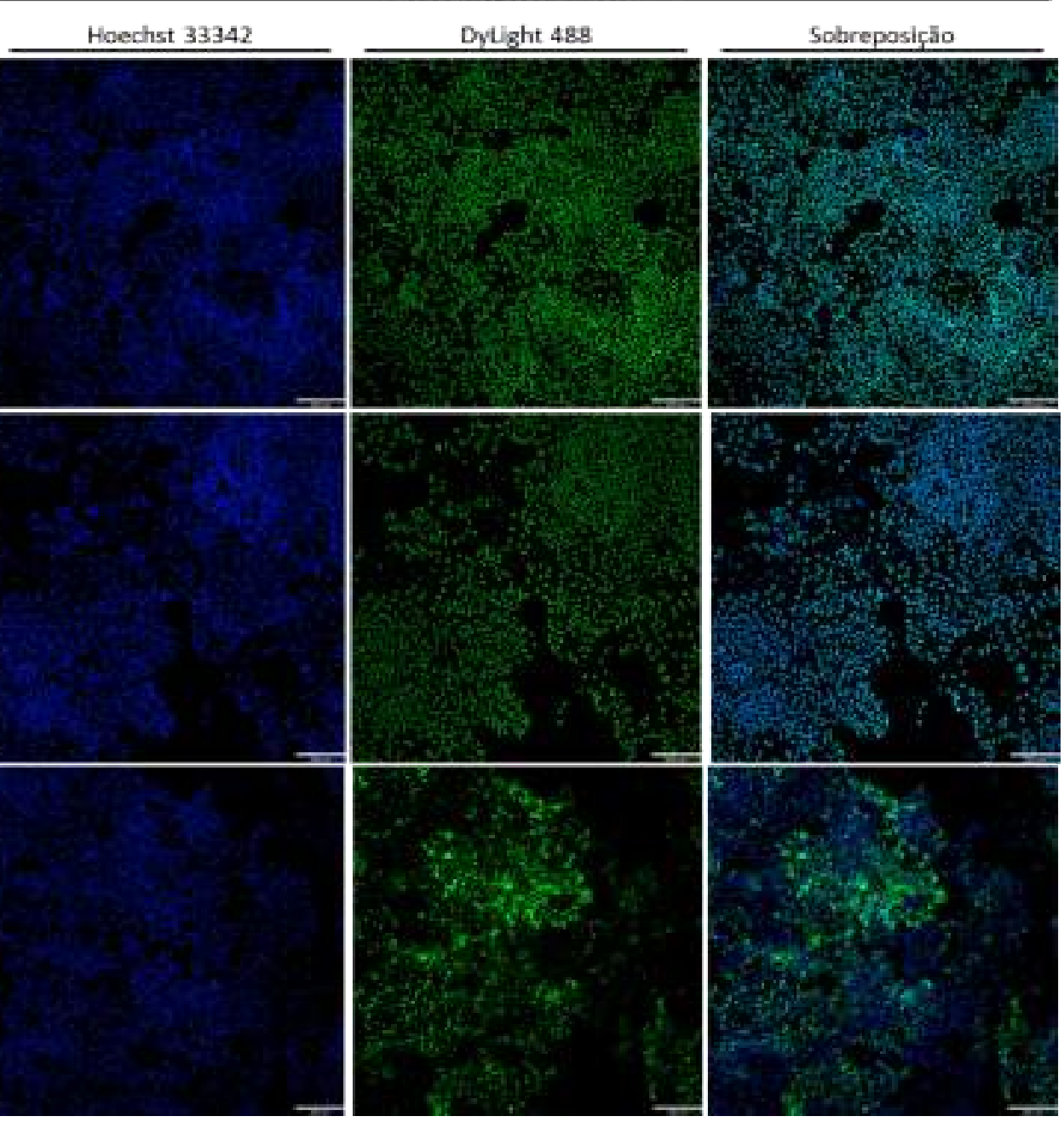

Figura 5. Células das linhagens H1 e NTera-2 marcadas com anticorpos para OCT4, SOX-2 e TRA-1-81. Foi realizada uma marcação nucelar com Hoechst 33342 (azul), uma imunomarcação indireta com anticorpos secundários conjugados ao fluorocromo DyLight 488 (verde) e a sobreposição das imagens. 


\subsection{Definição do protocolo de imunomarcação}

Inicialmente, foram definidas as melhores condições para a realização da marcação com os anticorpos e outros marcadores utilizados para as análises baseadas em imagem. Dessa forma, realizamos um teste com diversas densidades celulares (variando de $1 \times 10^{3}$ a $1 \times 10^{4}$ células por poço de uma placa de 96 poços, para a linhagem NTera-2; e de $3 \times 10^{3}$ a $3 \times 10^{4}$, para a linhagem H1). Uma vez escolhidas as densidades celulares para o ensaio, foi feita uma avaliação do melhor método para fixação das células, sendo comparadas duas soluções fixadoras: 2\% de formol (Sigma-Aldrich, \#F1635) em PBS (Phosphate-buffered saline, tampão fosfato-salino) ou em metanol (MeOH, Merck, \#106009). Para tal, cerca de $4 \times 10^{3}$ células da linhagem NTera- 2 foram cultivadas em placas de 96 poços por quatro dias, em $100 \mu \mathrm{L}$ de meio de cultura, nas condições de cultivo já apresentadas. Terminado este período, o meio de cultura foi retirado dos poços, e as células lavadas duas vezes com PBS (sempre utilizando um volume de $50 \mu \mathrm{L}$ ) e então submetidas à fixação com $50 \mu \mathrm{L}$ /poço das soluções descritas anteriormente.

Para a fixação com a solução de formol em PBS, as células foram incubadas por 15 minutos com o fixador e, em seguida, lavadas mais duas vezes com PBS. Uma vez concluída a fixação, foi então realizada a etapa de quenching com glicina $(50 \mu \mathrm{L} /$ poço, $0,1 \mathrm{M}$, SigmaAldrich, \#50046), com a função de neutralizar os grupos funcionais livres, passíveis de formar ligações covalentes inespecíficas com os anticorpos a serem utilizados. Esta etapa foi seguida da permeabilização das membranas celulares, utilizando Tryton X $(50 \mu \mathrm{L} /$ poço $0,3 \%$, Agilent, \#5188-5903) por 10 minutos. Uma vez finalizadas essas três etapas, foi feita uma marcação de núcleo com o corante de DNA, Hoechst 33342 (1 $1 \mu \mathrm{M}$, Thermo Fisher, \#H1399).

No caso da fixação com a solução de formol em $\mathrm{MeOH}$, a solução foi adicionada gelada e as placas foram mantidas em freezer $\left(-20^{\circ} \mathrm{C}\right)$ durante a incubação de 20 minutos. A solução com $\mathrm{MeOH}$, além de promover a fixação da amostra, também é permeabilizadora, já que este solvente orgânico causa rompimentos das membranas biológicas. Dessa forma, após a incubação de fixação, os poços foram lavados duas vezes com PBS e, em seguida, foi realizada a etapa de quenching com glicina. Uma vez fixadas, permeabilizadas e submetidas ao quenching, as células tiveram seus núcleos corados utilizando-se Hoechst 33342.

Depois da marcação nuclear, foi feito o imageamento dos poços utilizando-se o microscópio invertido de fluorescência automatizado do sistema de HCS ImageXpress Micro XLS (Molecular Devices). Como pode ser visualizado na Figura 6, a fixação com a solução 
de formol em PBS levou a uma grande perda do número de células, o que provavelmente resultou da etapa de permeabilização com o detergente. Além do teste citado aqui, diferentes concentrações do solvente, variações no tempo de incubação para permeabilização e até variação na concentração de formol foram realizadas na intenção de se obter um melhor protocolo para fixação, na linhagem NTera-2, utilizando-se essa solução fixadora, mas todas resultaram numa grande perda de células ao final do processo.

Já o processo de fixação realizado com a solução de formol em $\mathrm{MeOH}$, como também pode ser visto na Figura 6, apresentou um bom resultado, sem grande perdas de células e, aparentemente, sem alterações significativas na estrutura dessas. Sendo assim, esta solução foi escolhida para o prosseguimento dos experimentos.

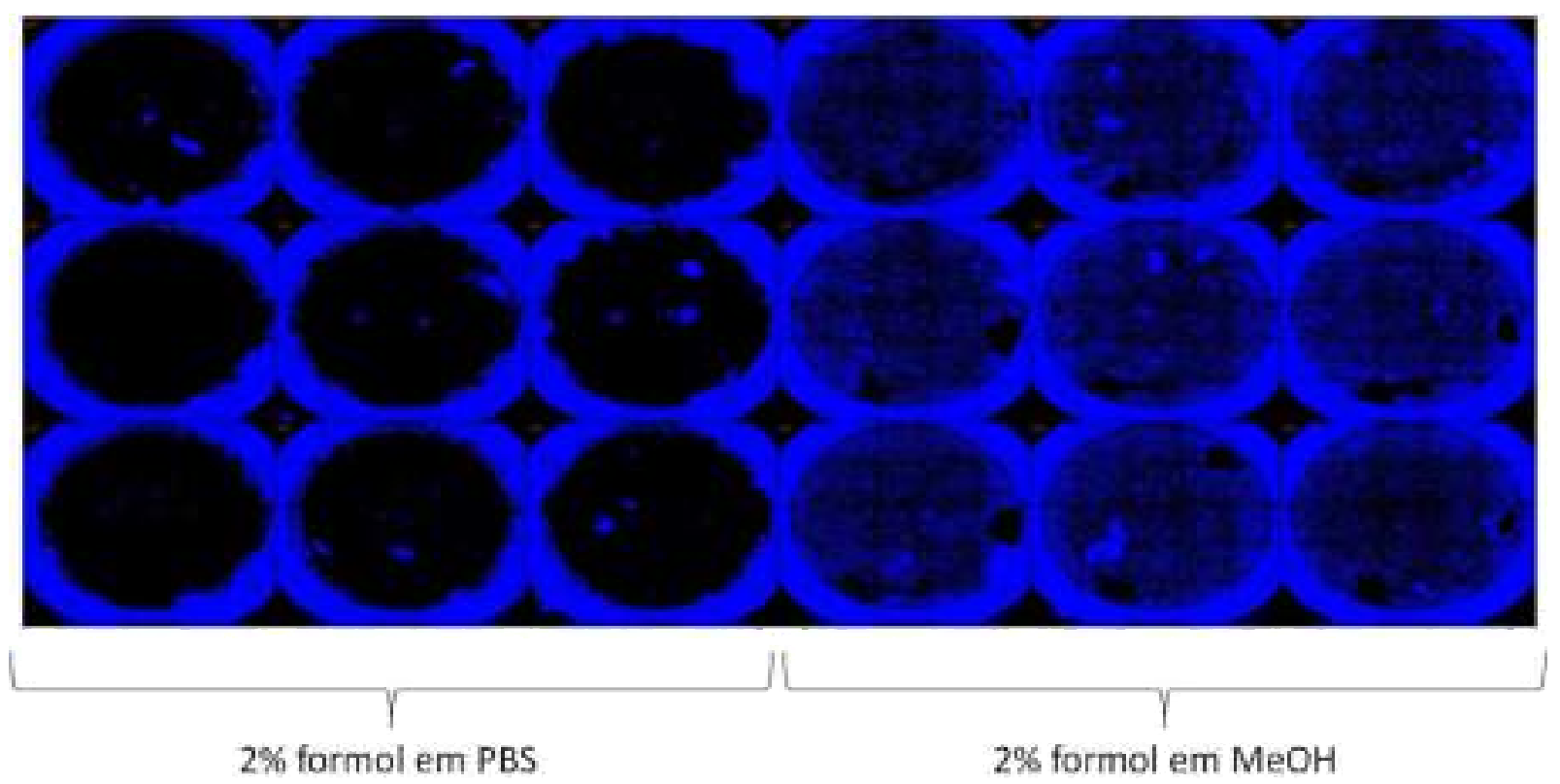

Figura 6: Imagens geradas a partir de culturas de NTera-2 em poços de uma placa de 96 poços, marcadas com Hoechst 33342, após os processos de fixação e permeabilização com $2 \%$ de formol em PBS ou em metanol $(\mathrm{MeOH})$ gelado. Nota-se que, nos poços fixados com formol em PBS e posteriormente submetidos ao processo de permeabilização com detergente, há uma grande perda de células (evidenciado pela ausência de marcação de Hoechst 33342 no centro dos poços), enquanto naqueles fixados com formol em $\mathrm{MeOH}$ gelado não se observa uma perda significativa de células.

Uma vez definida a solução fixadora a ser empregada para os experimentos baseados em microscopia, realizou-se o processo completo de imunomarcação, com o propósito de identificar alterações morfométricas e de expressão proteica que indicassem uma modulação do fenótipo pluripotente das linhagens utilizadas neste estudo.

Esse protocolo inclui, além das etapas já descritas anteriormente, uma etapa de bloqueio, usando uma solução de 1\% de SFB em PBS (50 $\mu \mathrm{L}$ por poço, por 30 minutos). Após o bloqueio, foi feita a incubação overnight (em geladeira, de $2^{\circ} \mathrm{C}$ a $8^{\circ} \mathrm{C}$ ) com uma solução 
contendo o anticorpo primário anti-OCT4 (Santa Cruz Biotechnology, \#9081, diluição 1:200; $50 \mu \mathrm{L}$ por poço). Finalizada a marcação com o anticorpo primário, as células foram lavadas três vezes com PBS e incubadas com uma solução contendo o anticorpo secundário de escolha (conjugado a um fluorocromo) e marcadores de núcleo e citoplasma. Essa incubação foi realizada em temperatura ambiente, por 45 minutos, seguidas de outras três lavagens com PBS. Por fim, os poços foram mantidos com $100 \mu \mathrm{L}$ de PBS cada e o imageamento foi realizado utilizando-se o sistema de HCS ImageXpress XLS. Uma melhor descrição sobre as configurações deste sistema de microscopia automatizada encontra-se no Anexo 01.

A Figura 7 ilustra a marcação de OCT4 e de um marcador celular (CellMask ${ }^{\circledR}$ Deep Red, Molecular Probes, Thermo Fisher, \#H32721) na linhagem NT2. As imagens representam um grupo de células no seu estado pluripotente $(\mathbf{A})$ e outro que foi induzido à diferenciação com atRA (all-trans-retinoic acid, Sigma-Aldrich; 10 $\mu \mathrm{M}$ ) (ANDREWS, 1984) por quatro dias (B). Pôde-se observar que a marcação de OCT4 foi nuclear, o que condiz com um fator de transcrição ativo e que regula o estado de pluripotência. Com a indução de diferenciação celular, houve uma diminuição do número de células positivas para esta marcação, assim como uma diminuição na intensidade de fluorescência naqueles núcleos que ainda apresentavam a marcação de OCT4.
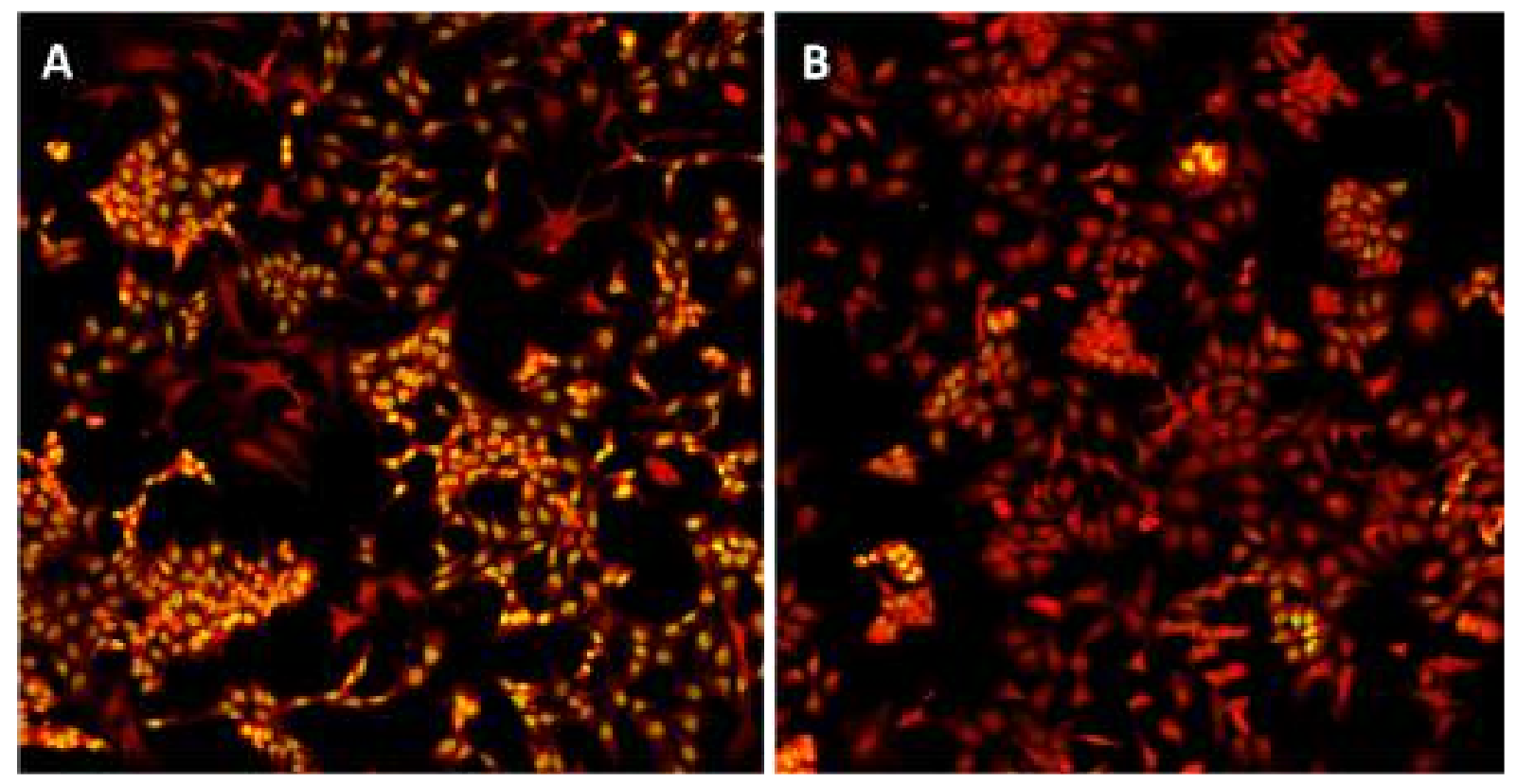

Figura 7. Fotomicrografia de células NTera-2 feitas por microscopia de fluorescência, onde são visualizadas as marcações para OCT4 (em verde) e para citoplasma (em vermelho). A) É possível se observar a grande quantidade de núcleos positivos para OCT4 (marcador de pluripotência). B) Culturas tratadas com ácido transretinóico (indutor de diferenciação celular) apresentam uma diminuição no número de células OCT4 positivas (Objetiva: 10X, ImageXpress). 


\subsection{Validação funcional do ensaio para avaliação da modulação da pluripotência}

Com o intuito de avaliar a capacidade do ensaio para identificar alterações morfológicas e fenotípicas em células pluripotentes transfectadas com miRNAs, foi realizado um teste para validação funcional. Assim, foram utilizadas moléculas sintéticas miméticas de miRNAs (miR mimic), sendo um conhecidamente relacionado à pluripotência (miR-302b-3p; Ambion, \#AM17100, ID: PM10081) e um relacionado com a diferenciação celular (miR-29b3p; Ambion, \#AM17100, ID: PM10103).

Para isso, foi realizada a transfecção reversa dessas moléculas na linhagem NTera-2, utilizando-se Lipofectamina 2000 (Thermo Scientific, \#11668030) na concentração de $0,05 \mu \mathrm{L} / 100 \mu \mathrm{L}$ de volume final (v.f). Essas condições de lipofecção foram previamente definidas, utilizando-se diferentes reagentes de transfecção em diferentes concentrações. A Lipofectamina foi diluída em Opti-MEM (Gibco, \#31985-088), onde $0,05 \mu \mathrm{L}$ do reagente de transfecção foi adicionado para cada $9,95 \mu \mathrm{L}$ de meio. Para as moléculas sintéticas de miRNAs (já citados anteriormente e uma molécula controle negativo [PMC]; Ambion, \#AM17110), foram diluídas em Opti-MEM para a concentração de $500 \mathrm{nM}$, sendo que $10 \mu \mathrm{L}$ dessa solução seriam utilizados por poço (concentração final de 50nM). Essas soluções foram incubadas separadamente por 5 minutos e, em seguida, foram somados $10 \mu \mathrm{L}$ de cada (reagente de transfecção + mimic-miR) por poço, formando um total de $20 \mu \mathrm{L}$ de solução por poço da placa de 96 poços. Esta mistura foi incubada por 30 minutos em condições de cultivo e então foram adicionados $80 \mu \mathrm{L}$ de suspensão celular (contendo $4 \times 10^{3}$ células) por poço. As placas foram mantidas imóveis por cerca de cinco minutos e então transferidas para a estufa, para garantir uma distribuição mais uniforme das células no poço.

A placa foi mantida por quatro dias em incubadora, nas condições de cultivo previamente descritas. Após este período, as células foram fixadas e submetidas ao protocolo de marcação descrito no item anterior, seguido da aquisição de imagens no sistema de HCS ImageXpress XLS. Essas imagens foram analisadas utilizando-se o software MetaXpress do próprio sistema de HCS. A marcação para a célula e núcleo foi realizada com CellMask®Blue (CellMask®Blue, Life Technologies, \#H32720, 1:10.000) e Hoechst 33342, sendo ambos visualizados no cubo de detecção de fluorescência DAPI, enquanto a marcação para OCT4 foi observada no cubo FITC, sendo que o anticorpo secundário estava conjugado com DyLight 488.

Com o uso do módulo de aplicação denominado "Multi-wavelength cell scoring", foi feita inicialmente a deteç̧ão da região nuclear (marcada mais intensamente com Hoechst 
33342), em seguida da região celular (onde o citoplasma foi marcado de forma menos intensa com o CellMask®Blue) e, por fim, dos núcleos positivos para OCT4 (Figura 8). Com a deteção destes objetos, foram realizadas as seguintes quantificações: contagem de núcleos, medida da área celular, porcentagem de núcleos positivos para OCT4 e intensidade de fluorescência da marcação de OCT4 nos núcleos.
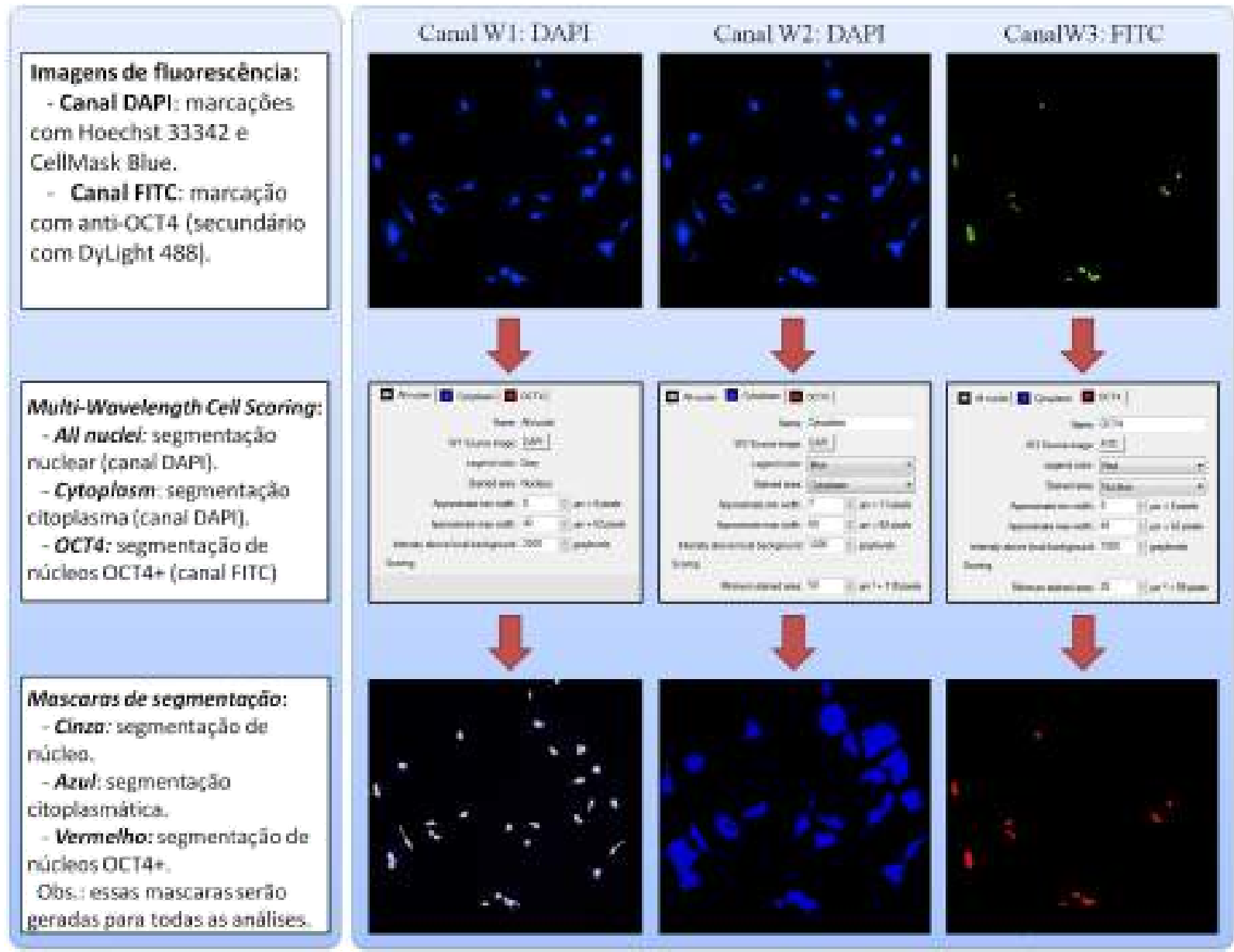

Mutti-Wavelength Cell Scaring: oplasma (canal DAPI).

- oCr4i segmentação de núcleas OCT4+ (canal FITC

Figura 8. Representação dos passos realizados para a segmentação das imagens de microscopia de fluorescência, utilizando o módulo de aplicação Multi-Wavelength Cell Scoring, do software MetaXpress, para a realização das análises de diferenciação e proliferação celular. Enquanto a análise de diferenciação se baseia nas alterações da porcentagem de células OCT4+ e das intensidades de fluorescência no canal de FITC, a análise de proliferação se baseia na contagem total de núcleos.

\subsection{Ensaio para avaliação do efeito dos miRNAs sobre a plutipotência em células}

\section{humanas}

No presente estudo, foi avaliado o efeito de 31 miRNAs (Tabela 01, Anexo 02) sobre o fenótipo pluripotente de células humanas. A escolha desse conjunto foi baseada em miRNAs que, de acordo com a literatura científica, se mostraram diferencialmente expressos em células pluripotentes e células diferenciadas ou em diferenciação (MARSON et al., 2008a; STADLER et al., 2010). 
Para isso, moléculas sintéticas miméticas (Ambion ${ }^{\circledR}$ Pre-mir ${ }^{\mathrm{TM}}$ miRNA Precursors; $m i R$ mimics) de cada um dos miRNAs escolhidos foram diluídos em Opti-MEM (para a concentração de $500 \mathrm{nM}$ ) e $10 \mu \mathrm{L}$ destas soluções foram distribuídos em poços de placas de 96 poços próprias para imageamento (Costar, \#3603), de acordo com os esquemas apresentados na Figura 9. Os poços externos não foram utilizados para evitar o "efeito borda", caracterizado por um comportamento biológico heterogêneo resultante das maiores variações de umidade, atmosfera e temperatura que estas células estão expostas. Em seguida, foi adicionada a solução contendo o reagente de transfecção, sendo para a linhagem NTera-2 a Lipofectamina $2000(0,05 \mu \mathrm{L} /$ poço) e para a linhagem H1, DharmaFECT-4 (0,1 $\mu \mathrm{L} /$ poço; Dharmacon, \#T-2004-03). Essa mistura foi incubada por um período de 30 minutos, em condições de cultivo, e em seguida foram adicionados $80 \mu \mathrm{L}$ de suspenção celular. Para a linhagem NTera-2, as células foram suspendidas em DMEM high glucose contendo $10 \%$ de SFB de tal forma que $4 \times 10^{3}$ células fossem distribuídas por poço. Já para a linhagem de CTE, essas foram suspendidas em mTeSR ${ }^{\mathrm{TM}} 1$ contendo inibidor de Rock $(10 \mu \mathrm{M})$, sendo que $6 \times 10^{3}$ células foram distribuídas por poço.

Uma vez plaqueadas, as células NTera-2 foram incubadas por quatro dias nas condições de cultivo já descritas, sem troca de meio de cultura, e então foram fixadas com a solução de formol $(2 \%)$ em $\mathrm{MeOH}$, seguindo o protocolo descrito anteriormente. Para a linhagem $\mathrm{H} 1$, foram adicionados $100 \mu \mathrm{L}$ de meio de cultura 24 horas após a transfecção e, 24 horas após esta adição, foi retirado o meio de cultura $(200 \mu \mathrm{L})$ e adicionado mais $100 \mu \mathrm{L}$ de mTeSR ${ }^{\mathrm{TM}} 1$. A fixação destas células foi realizada após o período de três dias de cultura, de modo a evitar a confluência total no poço.

Tabela 1. Relação dos miRNAs selecionados para avaliação de efeito modulatório sobre o fenótipo pluripotente de células humanas.

\begin{tabular}{lll}
\hline MiRNA & ID_Ambion & Relacionado com: $^{1,2}$ \\
\hline hsa-miR-17-3p & PM12246 & Pluripotência $^{1}$ \\
hsa-miR-18a-5p & PM12973 & Pluripotência $^{1}$ \\
hsa-miR-18b-5p & PM10466 & Pluripotência $^{1,2}$ \\
hsa-miR-19a-3p & PM10649 & Pluripotência $^{1}$ \\
hsa-miR-19b-3p & PM10629 & Pluripotência $^{1}$ \\
hsa-miR-20a-5p & PM10057 & Pluripotência $^{1}$ \\
hsa-miR-20b-5p & PM10975 & Pluripotência $^{1}$ \\
hsa-miR-21-5p & PM10206 & Diferenciação Celular $^{3,4}$
\end{tabular}




\begin{tabular}{|c|c|c|}
\hline hsa-miR-22-3p & PM10203 & Diferenciação Celular ${ }^{3,4}$ \\
\hline hsa-miR-23a-3p & PM10644 & Diferenciação Celular ${ }^{3}$ \\
\hline hsa-miR-24-3p & PM10737 & Diferenciação Celular ${ }^{3}$ \\
\hline hsa-miR-27a-3p & PM10939 & Diferenciação Celular ${ }^{3}$ \\
\hline hsa-miR-29a-3p & PM12499 & Diferenciação Celular ${ }^{3,4}$ \\
\hline hsa-miR-29b-3p & PM10103 & Diferenciação Celular ${ }^{4}$ \\
\hline hsa-miR-30a-5p & PM11062 & Diferenciação Celular ${ }^{3,4}$ \\
\hline hsa-miR-92a-3p & PM10916 & Pluripotência $^{5}$ \\
\hline hsa-miR-101-3p & PM11414 & Pluripotência $^{1}$ \\
\hline hsa-miR-106a-5p & PM12567 & Pluripotência $^{5}$ \\
\hline hsa-miR-145-5p & PM11480 & Diferenciação Celular ${ }^{3}$ \\
\hline hsa-miR-181d-5p & PM12522 & Diferenciação Celular ${ }^{3}$ \\
\hline hsa-miR-222-3p & PM11376 & Diferenciação Celular ${ }^{3}$ \\
\hline hsa-miR-302a-3p & PM10936 & Pluripotência ${ }^{1,2}$ \\
\hline hsa-miR-302a-5p & PM12557 & Pluripotência ${ }^{1,2}$ \\
\hline hsa-miR-302b-3p & PM10081 & Pluripotência ${ }^{1,2}$ \\
\hline hsa-miR-302b-5p & PM12916 & Pluripotência ${ }^{1,2}$ \\
\hline hsa-miR-302c-3p & PM10571 & Pluripotência ${ }^{1,2}$ \\
\hline hsa-miR-302d-3p & PM10927 & Pluripotência ${ }^{1,2}$ \\
\hline hsa-miR-363-3p & PM10149 & Pluripotência ${ }^{1,2}$ \\
\hline hsa-miR-371a-3p & PM12262 & Pluripotência $^{5}$ \\
\hline hsa-miR-372-3p & PM10165 & Pluripotência $^{5}$ \\
\hline hsa-miR-373-3p & PM11024 & Pluripotência ${ }^{5}$ \\
\hline
\end{tabular}

1: Baixa expressão durante a diferenciação celular em CTE humanas; 2: Baixa expressão durante a diferenciação celular em NTera-2; 3: Alta expressão durante a diferenciação celular em CTE humanas; 4: Alta expressão durante a diferenciação celular em NTera-2; 5: Alta expressão do miRNA ortólogo em células pluripotentes murinas. 
Placa 01

A

D

E

F

G

Placa 02

\begin{tabular}{|c|c|c|c|c|c|c|c|c|c|c|c|}
\hline 1 & 2 & 3 & 4 & 5 & 6 & 7 & 8 & 9 & 10 & 11 & 12 \\
\hline PBS & PBS & PBS & PBS & PBS & PBS & PBS & PBS & PBS & PBS & PBS & PBS \\
\hline PBS & PMC & Mock & miR-17-3p & miR-18a-5p & miR-18b-5p & miR-19a-3p & miR-19b-3p & miR-20a-5p & miR-20b-5p & esiOCT4 & PBS \\
\hline PBS & PMC & Mock & miR-17-3p & miR-18a-5p & miR-18b-5p & miR-19a-3p & miR-19b-3p & miR-20a-5p & miR-20b-5p & esiOCT4 & PBS \\
\hline PBS & PMC & Mock & miR-17-3p & miR-18a-5p & miR-18b-5p & miR-19a-3p & miR-19b-3p & miR-20a-5p & miR-20b-5p & esiOCT4 & PBS \\
\hline PBS & PMC+atRA & miR-21-5p & miR-22-3p & miR-23a-3p & $\mathrm{miR}-24-3 \mathrm{p}$ & miR-27a-3p & miR-29a-3p & miR-29b-3p & miR-30a-5p & siUBC & PBS \\
\hline PBS & PMC+atRA & miR-21-5p & miR-22-3p & $\operatorname{miR}-23 \mathrm{a}-3 \mathrm{p}$ & miR-24-3p & miR-27a-3p & $\operatorname{miR}-29 a-3 p$ & miR-29b-3p & miR-30a- $5 p$ & siUBC & PBS \\
\hline PBS & PMC+atRA & miR-21-5p & miR-22-3p & miR-23a-3p & miR-24-3p & miR-27a-3p & miR-29a-3p & miR-29b-3p & miR-30a-5p & siUBC & PBS \\
\hline PBS & PBS & PBS & PBS & PBS & PBS & PBS & PBS & PBS & PBS & PBS & PBS \\
\hline
\end{tabular}

\begin{tabular}{|c|c|c|c|c|c|c|c|c|c|c|c|}
\hline 1 & 2 & 3 & 4 & 5 & 6 & 7 & 8 & 9 & 10 & 11 & 12 \\
\hline PBS & PBS & PBS & PBS & PBS & PBS & PBS & PBS & PBS & PBS & PBS & PBS \\
\hline PBS & PMC & miR-92a-3p & miR-101-3p & miR-106a-5p & miR-145-5p & miR-181d-5p & $\mathrm{miR}-222-3 \mathrm{p}$ & miR-302a-3p & miR-301a-5p & esiOCT 4 & PBS \\
\hline PBS & PMC & miR-92a-3p & miR-101-3p & miR-106a-5p & miR-145-5p & miR-181d-5p & miR-222-3p & miR-302a-3p & miR-301a-5p & esiOCT 4 & PBS \\
\hline PBS & PMC & miR-92a-3p & miR-101-3p & miR-106a-5p & miR-145-5p & miR-181d-5p & $\mathrm{miR}-222-3 \mathrm{p}$ & miR-302a-3p & miR-301a-5p & esiOCT 4 & PBS \\
\hline PBS & PMC+atRA & miR-302b-3p & miR-302b-5p & miR-302c-3p & miR-302d-3p & miR-363-3p & miR-371a-3p & miR-372-3p & miR-373-3p & siUBC & PBS \\
\hline PBS & PMC+atRA & miR-302b-3p & miR-302b-5p & miR-302c-3p & miR-302d-3p & miR-363-3p & $\operatorname{miR}-371 a-3 p$ & miR-372-3p & miR-373-3p & siUBC & PBS \\
\hline PBS & PMC+atRA & miR-302b-3p & miR-302b-5p & miR-302c-3p & miR-302d-3p & miR-363-3p & miR-371a-3p & miR-372-3p & miR-373-3p & siUBC & PBS \\
\hline PBS & PBS & PBS & PBS & PBS & PBS & PBS & PBS & PBS & PBS & PBS & PBS \\
\hline
\end{tabular}

Figura 9. Esquemas de tratamentos nas placas de 96 poços próprias para imageamento. As bordas das placas foram preenchidas com PBS para evitar o efeito de borda, pois esta é uma área mais suscetível às variações de temperatura, humidade e modificações de atmosfera 
Além dos miR mimics para os alvos do estudo, também foram utilizadas diferentes moléculas controles: uma molécula de controle negativo (PMC; Ambion ${ }^{\circledR}$ Pre-mir ${ }^{\mathrm{TM}}$ miRNA Precursor Control, 50nM); um pool de siRNA contra Ubiquitina C (siRNA-UBC; letal; Thermo Scientific, \#M-019408-01, 30nM), para avaliar funcionalmente a transfecção; e um siRNA contra OCT4 (esiRNA-OCT4, Sigma-Aldrich, \#EHU223451, 3ng/ $\mu \mathrm{L}$ ), para avaliar quantitativamente o ensaio de HCS. Ainda, no dia seguinte à transfecção, um conjunto de células recebeu um estímulo de diferenciação pela adição de atRA (concentração final de $10 \mu \mathrm{M})$ nos poços.

Uma vez fixadas e permeabilizadas, foram realizadas as etapas de quenching com glicina, bloqueio com 1\% de SFB em PBS e então a marcação com os anticorpos primários, numa solução única, sendo adicionados $50 \mu \mathrm{L}$ desta por poço. Para avaliar o efeito dos miRNAs sobre a pluripotência, foram utilizados dois anticorpos primários sendo um para OCT4 (IgG de camundongo anti-OCT4, Santa Cruz Biotechnology, \#sc-5279, 1:200), fator de transcrição essencial para a manutenção da pluripotência; e um para Ciclina B1 (IgG de coelho anti-Ciclina B1, Santa Cruz Biotechnology, \#sc-595, 1:200), proteína que se acumula no citoplasma entre as fases S e G2 e se desloca para o núcleo celular durante a fase M. As células foram incubadas overnight com a solução contendo ambos os anticorpos primários, sendo depois lavadas três vezes com PBS, para então serem incubadas com uma solução $(50 \mu \mathrm{L} /$ poço) contendo os anticorpos secundários (IgG de cabra conjugada ao DyLight488 anti-IgG de camundongo, diluição: 1:300, Thermo Scientific, \#35503; e IgG de cabra conjugada ao DyLight594 anti-IgG de coelho, diluição: 1:300, Thermo Scientific, \#35561), o marcador nuclear (Hoechst 33342) e o marcador celular (CellMask ${ }^{\circledR B l u e), ~ p o r ~} 45$ minutos, em temperatura ambiente. Por fim, os poços foram lavados três vezes com PBS e mantidos com $100 \mu \mathrm{L}$ de PBS para o imageamento.

As fotomicrografias foram realizadas com o microscópio de fluorescência invertido do sistema de HCS ImageXpress XLS, utilizando os cubos para detecção de fluorescência DAPI (Hoechst 33342/CellMask®Blue), FITC (DyLight488) e Texas Red (DyLight594), objetiva de 10X, sendo obtidas nove imagens centrais justapostas (3X3) por poço para cada um dos cubos de fluorescência, o que totaliza 27 imagens por poço, 1620 imagens por placa, 3240 imagens ou 28,9GB de dados por experimento com cada linhagem celular. 


\subsection{Análise das imagens com o Cellprofiler.}

As imagens geradas na etapa anterior foram exportadas para serem analisadas com o uso do software de licença aberta CellProfiler 2.2 (http://cellprofiler.org). Esse software permite que sejam extraídos dados quantitativos a partir de fotomicrografias obtidas em microscópios de luz transmitida ou fluorescência. Foram obtidas informações sobre a morfologia das células, localização e intensidade de fluorescência dos marcadores OCT4 e Ciclina B1 (CCNB1).

Para essas quantificações, inicialmente o endereço da pasta onde se localizavam as imagens foram inseridos no programa e alguns filtros foram aplicados para eliminar da análise os arquivos que não fossem imagens de alta qualidade (ex.: arquivos de texto e miniaturas de imagens), pois somente estas contém as informações quantificáveis (Figura 10).

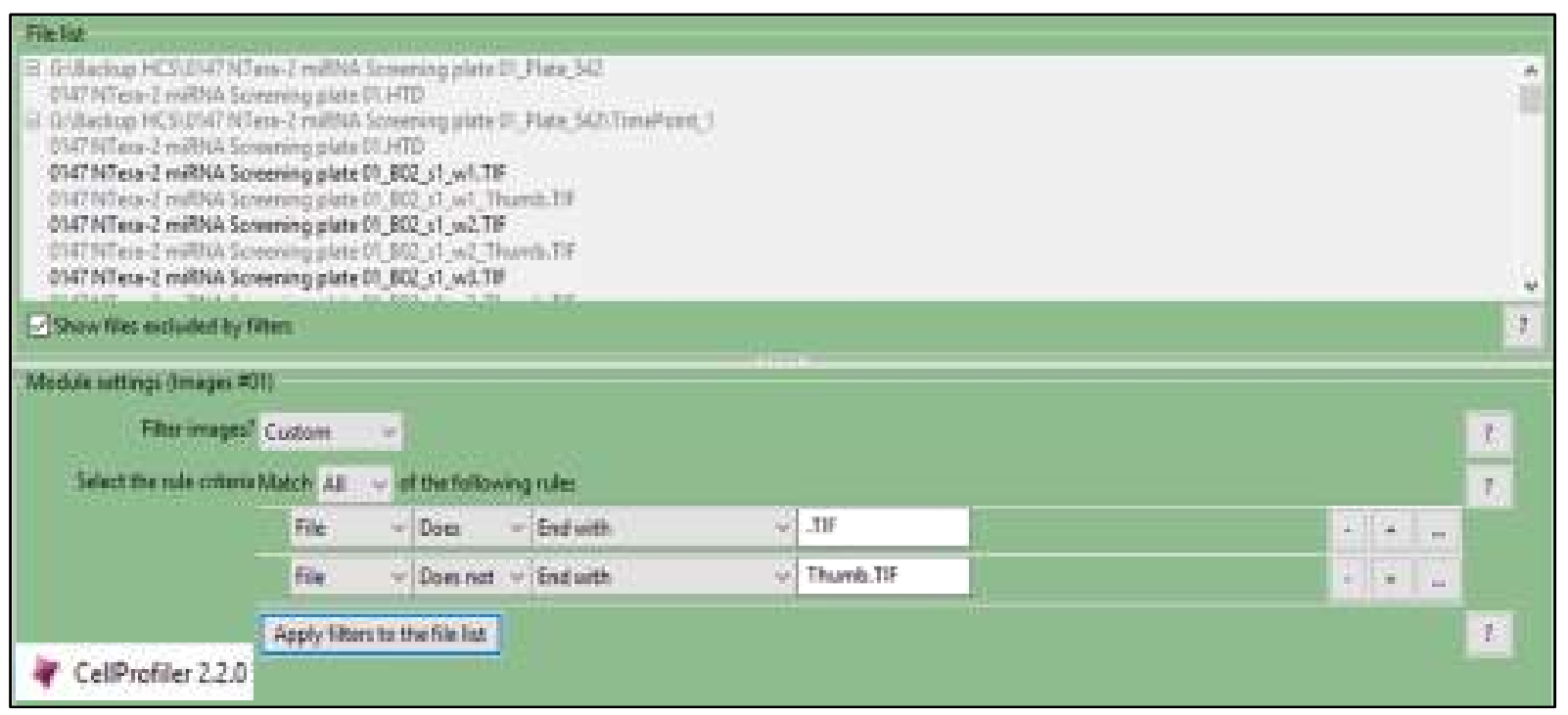

Figura 10. Janela do CellProfiler onde são inseridos os endereços das imagens que serão analisadas, bem como os filtros para seleção das imagens de alta qualidade.

Em seguida, foram extraídas informações que descrevem as imagens utilizando-se o módulo de metadados do software e que são armazenadas juntamente às quantificações feitas no Cellprofiler. Nesta ocasião, foram extraídos metadados do nome dos arquivos de imagem e de um arquivo de texto (.csv), os quais, quando cruzados, forneceram os seguintes dados: nome da placa, poços e sítios, cubos de detecção de fluorescência e tratamentos (Figura 11). 


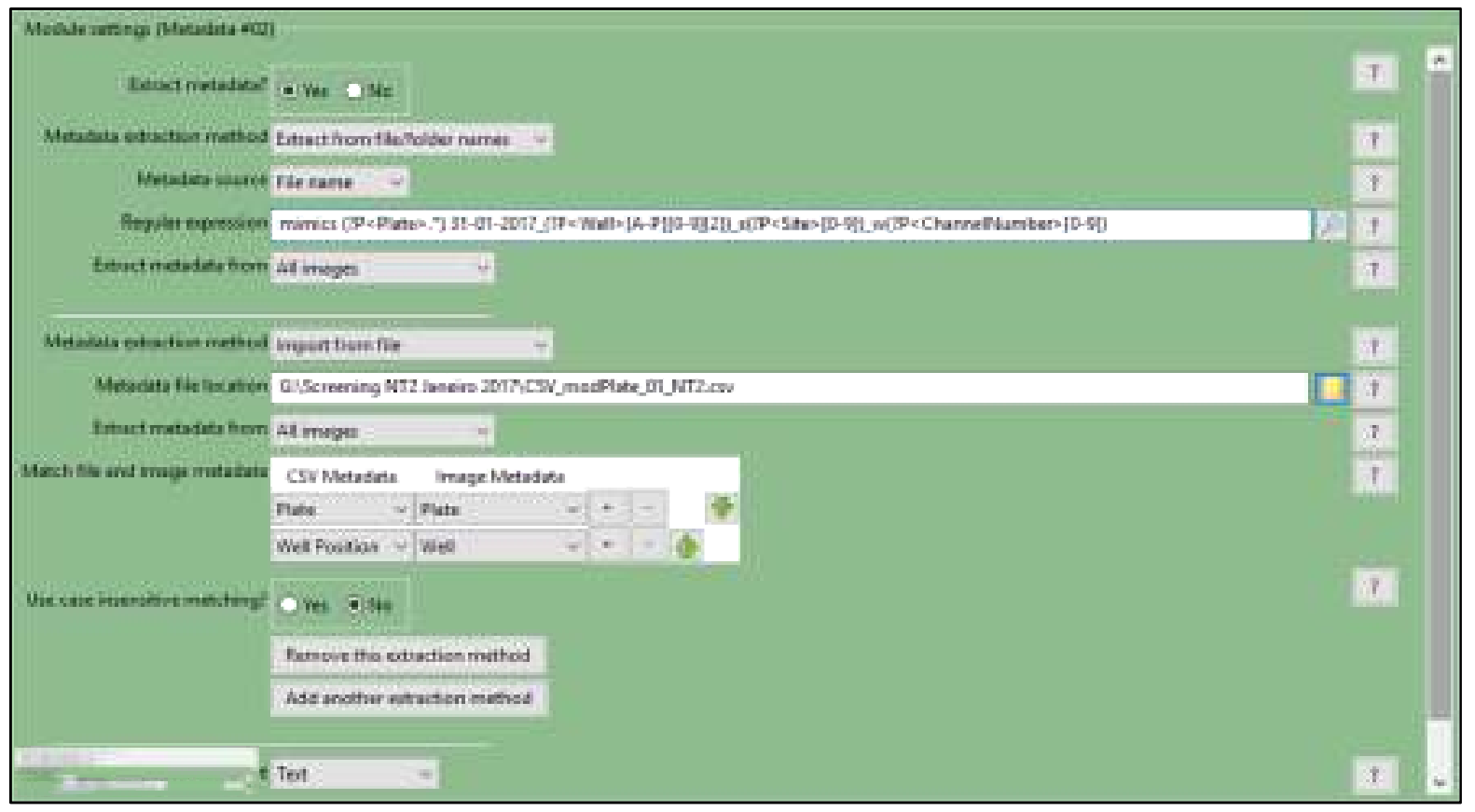

Figura 11. Janela do módulo de metadados no CellProfiler, onde são inseridos métodos de extração de metadados, os quais são utilizados pelo software e pelo analista para análises posteriores, pois neste momento são definidas informações como nome dos tratamentos e posicionamento destes nas placas de 96 poços.

O próximo passo foi realizado utilizando o módulo "nomes e tipos", com o qual foram designados os nomes dos marcadores visualizados pelos diferentes cubos de fluorescência (inicialmente identificados como "w1" para o cubo da DAPI, "w2" para FITC e "w3" para Texas Red). Dessa forma, cada imagem de cada sítio e poço respectivo puderam ser identificadas como Hoechst/CellMask ${ }^{\circledR B}$ Blue, OCT4 ou Ciclina B1 (Figura 12). Essas três etapas são chamadas de "módulos de input", os quais permitem a correta identificação de cada uma das imagens, para que então possam ser utilizadas pelos módulos de análises, onde serão identificados os objetos e as medidas que serão quantificados e liberados pelo software. 


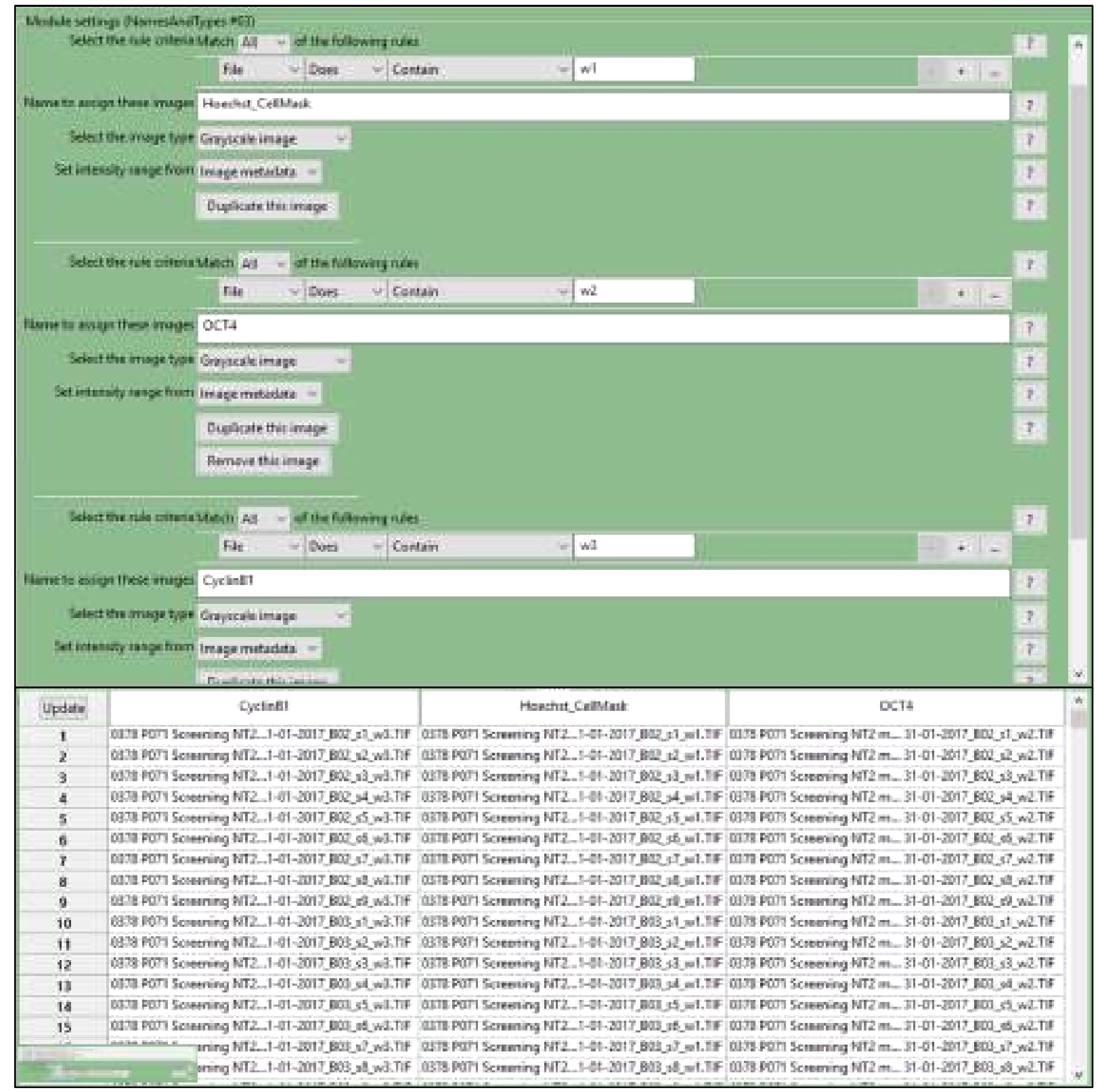

Figura 12. Janela do módulo "nomes e tipos" no CellProfiler, onde são identificados os nomes das marcações correspondentes a cada um dos conjuntos de imagens obtidos pelos diferentes cubos de detecção de fluorescência. Neste caso, foram utilizados três cubos de detecção, sendo um para a marcação de núcleo e da célula (w1, cubo DAPI), outro para OCT4 (w2, cubo FITC) e um terceiro para Ciclina B1 (w3, cubo Texas Red).

O primeiro módulo de análise utilizado foi o de "identificação de objetos primários". Objetos primários são aqueles que servirão de referência primária para identificação das estruturas que serão estudas (no caso, as células). Esses objetos devem ser de fácil identificação, sendo bem distintos do background (fundo), de formato mais simples e o mais individualisados possível, não tocando ou raramente tocando um outro objeto. A estrutura nas imagens que melhor cumprem essas exigências são os núcleos das células corados com 
Hoechst, portanto estes foram identificados como objetos primários, servindo de referência para a identificação da célula e de seus compartimentos (núcleo e citoplasma).

No módulo de identificação de objeto primário são inseridos alguns parâmetros pelo especialista, que é responsável por determinar as características que definem como é o núcleo das células nas imagens. Como exemplo, devem ser informados para o software o conjunto de imagens que será analisado (no caso, o de Hoechst/CellMask®Blue), os tamanhos mínimo e máximo dos objetos em píxels (valores que variam em função da objetiva utilizada, bem como da resolução do equipamento em uso), a estratégia e o método para determinação automática do valor limiar (threshold) de sinal de fluorescência utilizado para a distinção entre o objeto (foreground) e o fundo (background) ${ }_{2}$ o fator de correção para identificação do threshold e as estratégias que o software deve adotar para distinguir e estabelecer a linha divisória entre objetos justapostos. Esses parâmetros devem ser finamente ajustados de forma empírica até a obtenção de uma segmentação satisfatória, ou seja, capaz de detectar o maior número possível de núcleos da imagem, sem agrupar núcleos num mesmo objeto, ou dividir um núcleo em mais de um objeto. Em particular, utilizamos uma estratégia de threshold global baseada no método de Otsu com três classes de intensidade. Este método permite a identificação da intensidade limite entre o background (área sem células), a região citoplasmática com intensidade média corada pelo CellMask Blue (definida como background nesta etapa), e o núcleo corado intensamente por Hoechst (o objeto primário). Ainda, a menor intensidade de Hoechst entre os núcleos foi utilizada para separar e delinear os núcleos. Ao final deste processo, referido como segmentação do objetos primários da imagem, o programa gera uma mascara binária onde cada núcleo corresponde a um objeto, identificado por um número e por uma posição espacial definida pela localização de seu centro geométrico nos eixos x e y da imagem (em pixels, com origem no canto inferior esquerdo da imagem).

Uma vez determinado o objeto primário (núcleo), foi feita a identificação da célula como um todo, utilizando agora o módulo de "identificação de objetos secundários", os quais necessariamente incluem os objetos primários, compartilhando seu identificador. Diferentemente destes últimos, os objetos secundários podem apresentar uma forma mais complexa, como também estarem justapostos a outros objetos. Sendo assim, baseando-se no núcleo, podemos determinar qual é a região das células e distinguir as fronteiras entre uma célula e outra. Neste módulo, também é necessário escolher o conjunto de imagens que será utilizado (neste caso, também foi utilizado o conjunto de Hoechst/CellMask®Blue) e o especialista pode selecionar as estratégias e parâmetros que serão utilizados para a identificação do objetos secundários. Nesta etapa, foi novamente utilizada a estratégia de 
threshold global baseada no método de Otsu com três classes de intensidade, só que desta vez, definindo os pixels de intensidade intermediária como foreground, juntamente com o núcleo (gerando uma mascara com objetos correspondendo à célula inteira). Adicionalmente, utilizamos o método de propagação para identificar as fronteiras externas da célula, bem como para definir a linha de separação entre células justapostas.

Segmentados os núcleos e as células, a identificação da região citoplasmática foi realizada com o módulo "identificação de objetos terciários". Este módulo é muito mais simples e utiliza as informações dos modos anteriores para a identificação do objeto terciário, subtraindo assim a área do objeto menor (neste caso o núcleo) da área do objeto maior (a célula).

Utilizando esta estratégia, um único canal de fluorescência permitiu a identificação de ambos compartimentos celulares, como pode ser visualizado nas figura 13, onde o núcleo é fortemente marcado por Hoechst 33342, apresentando uma alta intensidade de fluorescência; e o citoplasma é marcado numa intensidade menor pelo CellMask ${ }^{\circledR B}$ lue.

Uma vez definidos os compartimentos celulares, foram selecionados os módulos de quantificação. Foram usados dois módulos, um voltado para as análises morfométricas, denominado "medida de tamanho e formato do objeto", e um segundo para avaliação das marcações fluorescentes, "medida de intensidade nos objetos". O primeiro foi usado para analisar núcleo e célula, fornecendo resultados como área, perímetro, raio, solidez e excentricidade dos objetos. O segundo, para se analisar as intensidades de marcação para OCT4 e CCNB1 nos compartimentos celulares (núcleo e citoplasma). Além dessas medidas, outras também foram realizadas, como a "medida de objetos vizinhos", a qual pode avaliar, por exemplo, o número de células que se encontram em contato com uma determinada célula e ainda a área da célula que se encontra em contato com outras.

Por fim, foram adicionados os módulos para exportação dos dados gerados a partir dos módulos anteriores para uma tabela, a qual foi utilizada para se avaliar o perfil fenotípico induzido por cada miRNA transfectado em ambas as linhagens celulares aqui utilizadas, NTera-2 e H1. Uma vez estruturados os módulos, com todos os parâmetros bem definidos, a pipeline gerada é aplicada a todas as imagens, de todos os poços e placas, garantindo assim uma análise equiparável em todos os tratamentos, de maneira não-supervisionada. 


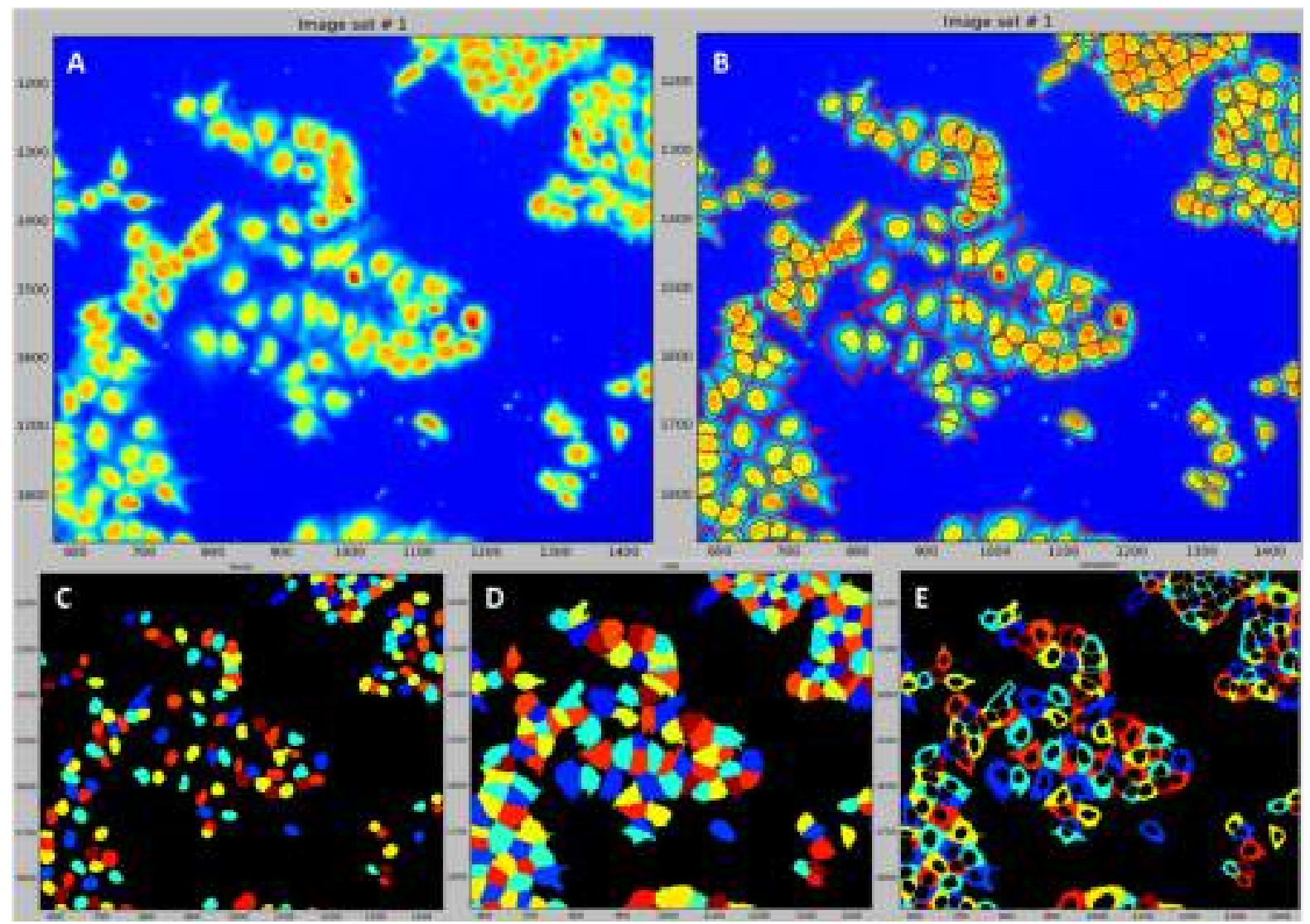

Figura 13. Visualização de uma região de uma imagem feita com o cubo DAPI para deteção da marcação de Hoechst 33342 e CellMask ${ }^{\circledR B}$ Blue, utilizando-se a ferramenta de visualização do CellProfiler. Em A, aplicou-se uma normalização em $\log$ da imagem, com uma atribuição de cores para diferentes intensidade de fluorescência (Heatmap definido por uma "Look up Table" - LUT), permitindo a observação dos núcleos com maior intensidade de fluorescência (entre vermelho e amarelo), do citoplasma com intensidade intermediária (em verde), e do background com intensidade baixas (em azul). Em B, pode-se ver a segmentação obtida pelo software, com um delineamento em preto para o núcleo e em vermelho para os limites celulares. A partir destas delimitações, são gerados as mascaras com os objetos núcleo (C), célula (D) e citoplasma (E), este último definido subtraindo-se a mascara do núcleo da mascara da célula.

\subsection{Agrupamento dos tratamentos miRNAs por similaridades fenotípicas induzidas}

A tabela de dados obtidas por meio do CellProfiler apresenta um grande número de informações, ou seja, é o resultado da análise de alto conteúdo (High Content Analysis). Este grande número de dados pode ser melhor estudado e organizado utilizando-se softwares específicos de gerenciamento de dados,como o KNIME (www.knime.org).

O KNIME é um software de licença aberta, que realiza diversas funções através de módulos matemáticos, os nodes, os quais são desenvolvidos para a realização de funções específicas, como leitura de arquivos, agrupamento dos dados, substituição ou filtragem dos dados, além de muitas outras. Por fim, este software apresenta grande versatilidade e pode ser utilizado para os mais diversos fins, como poderá ser visto no decorrer deste trabalho. Para 
esta etapa, o KNIME foi utilizado para agrupar os dados de cada um dos sítios dos diferentes poços, agrupar os resultados por tratamento e, por fim, filtrar os dados e gerar uma tabela com os parâmetros com maior relevância para a clusterização por similaridade fenotípica dos diferentes grupos de tratamento.

Dessa forma, inicialmente foram inseridos os dados brutos obtidos das análises com o CellProfiler, sendo utilizado o node de leitura de arquivos pra isso. Além dessa tabela, também foi utilizada uma tabela pra atualizar as informações de nomenclatura dos miRNAs aqui empregados, já que as moléculas foram obtidas da Ambion quando a nomenclatura ainda era baseada em um status de fita "madura" e fita "estrela". Um node conhecido como "substituidor de células" foi aplicado para isso. Para prosseguir com o gerenciamento dos dados, outros nodes foram adicionados, como:

- "filtros de coluna", para retirar informações que não seriam relevantes para as análises;

- "agrupar por", para agrupar inicialmente os dados dos sítios, gerando informações por poço e, depois, as informações dos poços, para gerar os dados por tratamento;

- "normalizar placas - POC (percentage of control)", que fez a comparação dos dados de cada poço com o controle negativo, liberando os resultados em porcentagem em relação ao controle negativo;

- "gerador de CSV", que exportou para uma tabela os dados reorganizados, filtrados e analisados no KNIME. Esta tabela contém os dados utilizados para a clusterização fenotípica.

A tabela resultante dos tratamentos com o KNIME foi inserida no software de clusterização Cluster 3.0 (http://bonsai.hgc.jp/ mdehoon/software/cluster/software.htm). A clusterização foi realizada utilizando-se o conjunto mínimo de parâmetros que pudesse apresentar as alterações fenotípicas induzidas pelos miRNA e agrupá-los de acordo com as semelhanças observadas entre eles. Por fim, foram usados treze parâmetros, aplicando uma correlação centrada como métrica similaridade para a clusterização hierárquica, e o método de clusterização ligação média. O resultado da clusterização foi visualizado por meio do Java Tree View 3.0 (http://jtreeview.sourceforge.net/).

\subsection{Predição in silico dos alvos e vias regulados pelos clusters de miRNAs}

Para esta etapa, foram utilizadas as informações dos miRNAs humanos e seus alvos obtidas no Taget Scan 7 (http://www.targetscan.org/vert 70/). Duas tabelas com os scores dos sítios de ligação de miRNAs conservados e não conservados foram inseridas e concatenadas utilizando o KNIME. Também foi inserida no workflow uma tabela contendo todos os 
miRNAs transfectados nas linhagens pluripotentes. A essa tabela foi ligado um node de "tabela interativa", a qual permite que alguns dados sejam selecionados numa tabela para, posteriormente, serem utilizados em outras operações. No caso, os miRNAs selecionados na tabela interativa foram aqueles pertecentes a um determinado cluster, para que então os alvos destes pudessem ser buscados na tabela criada a partir dos dados contidos no Target Scan. Uma vez encontrados os alvos para cada um dos miRNAs do cluster, foi utilizado um filtro para que somente permanecessem os mRNAs alvos de todos os miRNAs selecionados.

A lista de genes gerada para cada um dos alvos foi salva em uma tabela, utilizando-se o node "gerador de CSV". Para identificarmos as possíveis vias biológicas reguladas pelos miRNAs e que possivelmente levaram às alterações fenotípicas observadas nas células transfectadas, foi utilizada a ferramenta online DAVID 6.8 (Database for Annotation, Visualization and Integrated Discovery). Para isso, a lista de genes foi inserida na caixa de texto específica do DAVID, a espécie escolhida para análise foi $\underline{\text { Homo sapiens, }}$, e a ferramenta de "gráfico de anotação funcional" foi aplicada, escolhendo-se a detecção de vias nos bancos de dados "BBID", "BIOCARTA" e "KEGG_PATHWAY". Em seguida, das vias identificadas ao se cruzar a lista de genes alvos dos miRNAs, foram escolhidas aquelas com maior relevância para o contexto celular.

\subsection{Validação dos alvos identificados}

Uma vez identificados os possíveis alvos dos miRNAs de clusters específicos e as possíveis vias reguladas por eles para a indução dos perfis fenotípicos observados, foram escolhidos um ou mais miRNAs de cada cluster para validar funcionalmente o resultado. Sendo assim, os miR mimics dos representantes selecionados foram transfectados na linhagem NTera-2, por transfecção reversa utilizando-se Lipofectamina 2000 (concentração). Para tanto, as soluções de reagente de transfecção e miR mimics $(500 \mathrm{nM})$ ou controles negativo (PMC) e positivo (siRNA-GAPDH, Ambion, \#4390849; 100nM) foram preparadas e $115 \mu \mathrm{L}$ de cada solução foram misturados em placas de 12 poços e incubados por 30 minutos em condições de cultivo. Após este período, $920 \mu \mathrm{L}$ de suspensão celular contendo $9 \times 10^{4}$ células foram adicionados por poço, sendo então as placas levadas para incubadora e mantidas nas condições de cultivo previamente apresentadas por um período de $48 \mathrm{~h}$. Completado este período, o meio de cultura das células foi removido e os poços lavados duas vezes com PBS $(1 \mathrm{~mL}$ por poço), para que então fossem adicionados $250 \mu \mathrm{L}$ de PBS/DEPC (Dietilpirocarbonato; Sigma-Aldrich, \#D-5758; 0,01\%) em cada, seguidos de $750 \mu \mathrm{L}$ de 
TRIZOL LS (solução monofásica de fenol e isotiocianato de guanidina, Life Technologies, $\# 10296028)$. Esse material foi transferido para microtubos e mantidos em freezer $\left(-80^{\circ} \mathrm{C}\right)$ por, pelo menos, 24 horas.

Para a obtenção do RNA total das células transfectadas com os miR mimics e controles, as amostras foram descongeladas, em seguida foram adicionados $10 \mu \mathrm{L}$ de glicogênio e $200 \mu \mathrm{L}$ de clorofórmio por microtubo. Estes foram vortexados e depois centrifugados (14000rpm, 15 minutos, $4^{\circ} \mathrm{C}$ ), resultando na formação de duas fases nos tubos, uma aquosa e uma orgânica. A fase aquosa foi então transferida para um novo tubo e a precipitação do RNA foi realizada utilizando-se $500 \mu \mathrm{L}$ de isopropanol (Merck, \#1096341000) gelado $\left(2 \sim 8^{\circ} \mathrm{C}\right)$. As amostras foram deixadas em descanso, em temperatura ambiente por um período de aproximada 15 minutos, para que a precipitação total. Os microtubos foram novamente centrifugados nas condições anteriormente descritas e o sobrenadante foi descartado. O pellet de RNA formado foi ressuspendido em etanol $70 \% \mathrm{e}$ este material foi submetido a mais uma etapa de centrifugação. O sobrenadante foi desprezado, o pellet das amostras foram ressuspendidos em $15 \mu \mathrm{L}$ de água livre de nucleases (Invitrogen, \#10977-023) e mantidos em freezer $\left(-80^{\circ} \mathrm{C}\right)$ até a realização da transcrição reversa para obtenção do cDNA.

Para quantificação do RNA isolado, $1 \mu \mathrm{L}$ de cada amostra foi aplicado em um Nanovue Plus (General Eletronics) e avaliado por espctofotometria no comprimento de onda de 260 nm, utilizando equivalência de $40 \mu \mathrm{g} / \mathrm{mL}$ de RNA para 1 unidade de absorbância. O grau de pureza das amostras foi avaliado por meio das razões 260/280nm e 260/230nm, sendo utilizadas para as próximas etapas as amostras que apresentaram valores entre 1,6 e 1,8.

O cDNA de cada amostra foi obtido a partir da transcrição reversa de $1 \mu \mathrm{g}$ de RNA de cada amostra utilizando o High Capacity cDNA Archive Kit (Applied Biosystems, \#4368813), seguindo as instruções do fabricante. As amostras de cDNA foram diluídas para uma concentração final de $10 \mathrm{ng} / \mu \mathrm{L}$ em água livre de nucleases e essas foram utilizadas nas reações de qPCR para avaliação dos níveis de mRNA dos alvos específicos de cada miRNA identificados anteriomente.

As reações de qPCR foram executadas em duplicatas por amostra em placas ópticas para PCR em tempo real de 96 poços (Applied Biosystems, \#N8010560), utilizando primers ou sondas específicos para cada gene e o aparelho 7300 Real-Time PCR System (Applied Biosystems) A lista completa com os primers e sondas utilizados no presente trabalho, bem como condições de uso de cada um, se encontra nas Tabelas 02 e 03. 
Os resultados das reações foram analisados com o software Sequence Detection System V1.3 para a obtenção dos valores de CT, que foram exportados e posteriormente aplicados na fómula $2^{-\Delta \Delta C t}$ (PFAFFL, 2001), sendo que os valores de $\mathrm{Ct}$ de cada transcrito foram normalizados com os respectivos $\mathrm{Ct}$ de GAPDH de cada amostra, gerando o $\Delta \mathrm{Ct}$. Em seguida, subtraiu-se o valor médio de $\Delta \mathrm{Ct}$ das amostras controles dos valores de $\Delta \mathrm{Ct}$ dos transcritos de interesse das amostras tranfectadas com as moléculas de mimic-miRNA, para a obtenção do $\Delta \Delta \mathrm{Ct}$. Os valores de foldchange gerados de cada replicata das transfecções foram adicionadas no software GraphPad Prism 5 e foram comparados com o grupo PMC, utilizando o Teste T de Student, não-paramétrico.

Tabela 2. Lista de sondas utilizadas para a detecção de transcritos de genes identificados nas análises de vias moduladas pelos miRNAs

\begin{tabular}{lcc}
\hline Gene & \multicolumn{1}{c}{ Sonda } & TA \\
\hline APC & Hs00181051-m1 & $60^{\circ} \mathrm{C}$ \\
BMPR2 & Hs00176148_m1 & $60^{\circ} \mathrm{C}$ \\
CDKN2B & Hs00365249_m1 & $60^{\circ} \mathrm{C}$ \\
FGFR1 & Hs00241111_m1 & $60^{\circ} \mathrm{C}$ \\
GSK3B & Hs00275656_m1 & $60^{\circ} \mathrm{C}$ \\
IGF1R & Hs00609566_m1 & $60^{\circ} \mathrm{C}$ \\
MAPK1 & Hs01046830_m1 & $60^{\circ} \mathrm{C}$ \\
PTEN & Hs00829813_s1 & $60^{\circ} \mathrm{C}$ \\
RELA & Hs00153294_m1 & $60^{\circ} \mathrm{C}$ \\
STAT3 & HS00374280-m1 & $60^{\circ} \mathrm{C}$ \\
TGFB3 & Hs01086000_m1 & $60^{\circ} \mathrm{C}$ \\
TGFBR2 & HS00234253_m1 & $60^{\circ} \mathrm{C}$ \\
\hline
\end{tabular}

$\mathrm{TA}=$ temperatura de anelamento 
Tabela 3. Lista de primers de DNA utilizados para a deteção de transcritos de genes identificados nas análises de vias moduladas pelos miRNAs

\begin{tabular}{|c|c|c|c|}
\hline Gene & Sequência do Primer (5' - 3') & Concentração & TA \\
\hline APC & $\begin{array}{l}\text { F: CAGGAAGTATTGAAGATGAAGCTATG } \\
\text { R: CCATAAGAACGGAGGGACATT }\end{array}$ & $400 \mathrm{nM}$ & $62^{\circ} \mathrm{C}$ \\
\hline CDK6 & $\begin{array}{l}\text { F: GTGCCCACTGAAACCATAAAG } \\
\text { R: GTCAGCGAGTTTTATTTGTCCG }\end{array}$ & $400 \mathrm{nM}$ & $62^{\circ} \mathrm{C}$ \\
\hline GAPDH & $\begin{array}{l}\text { F: GAAGGTGAAGGTCGGAGTC } \\
\text { R: GAAGATGGTGATGGGATTTC }\end{array}$ & $200 \mathrm{nM}$ & $60^{\circ} \mathrm{C}$ \\
\hline GSK3ß & $\begin{array}{l}\text { F: GGTCTATCTTAATCTGGTGCTGG } \\
\text { R: TGGATATAGGCTAAACTTCGGAAC }\end{array}$ & $400 \mathrm{nM}$ & $62^{\circ} \mathrm{C}$ \\
\hline IL2RA & $\begin{array}{l}\text { F: TCATCTCATTCCAACTTCCCAG } \\
\text { R: TGAGAAAGGAACCACGCAG }\end{array}$ & $100 \mathrm{nM}$ & $60^{\circ} \mathrm{C}$ \\
\hline IL6ST & $\begin{array}{l}\text { F: GCAACATTCTTACATTCGGACAG } \\
\text { R: TCCCACTCACACCTCATTTTC }\end{array}$ & $150 \mathrm{nM}$ & $62,5^{\circ} \mathrm{C}$ \\
\hline KLF4 & $\begin{array}{l}\text { F: GATGAACTGACCAGGCACTA } \\
\text { R: GTGGGTCATATCCACTGTCT }\end{array}$ & $400 \mathrm{nM}$ & $60^{\circ} \mathrm{C}$ \\
\hline LIF & $\begin{array}{l}\text { F: AGTATAAGCAGATCATCGCCG } \\
\text { R: ATTTGGGTTTAGCGATGCC }\end{array}$ & $400 \mathrm{nM}$ & $60^{\circ} \mathrm{C}$ \\
\hline RELA & $\begin{array}{l}\text { F: TGACAAGGTGCAGAAAGAGG } \\
\text { R: CACATCAGCTTGCGAAAAGG }\end{array}$ & $300 \mathrm{nM}$ & $62^{\circ} \mathrm{C}$ \\
\hline SMAD2 & $\begin{array}{l}\text { F: GGTGTGAGAAAGCAGTGAAAAG } \\
\text { R: ACTCAGTCCCCAAATTTCAGAG }\end{array}$ & $400 \mathrm{nM}$ & $62^{\circ} \mathrm{C}$ \\
\hline TCF3 & $\begin{array}{l}\text { F: TTCTCGTCCAGCCCTTCTA } \\
\text { R: GGTGGTCTTCTATCTTACTCTGC }\end{array}$ & $400 \mathrm{nM}$ & $62^{\circ} \mathrm{C}$ \\
\hline
\end{tabular}




\subsection{Regulação de miRNAs sobre a diferenciação induzida pela via Notch}

Sabendo-se do papel desenpenhado pela via Notch na diferenciação de células pluripotentes, foi decidido que, adicionalmente à abordagem anteriormente citada para a identificação de vias reguladas pelos miRNAs em CTE e CCE, uma outra abordagem (agora supervisionada) seria aplicada para identificar miRNAs que possuiam componentes desta via de sinalização celular como alvos preditos. Deste modo, utilizando-se a ferramenta DAVID, foram identificados os genes que fazem parte de Notch e, com o uso do KNIME, esses dados foram cruzados com aqueles contidos no banco de dados Taget Scan 7, identificando assim quais componentes eram alvejados pelos miRNAs aqui estudados, bem como quantos e quais eram os miRNAs que alvejavam cada um dos diferentes componentes da via.

Para avaliar funcionalmente o efeito do possível silenciamento da via Notch pelos miRNAs e sua consequência na resposta de células pluripotentes ao estímulo de ativação desta via pelo DLL1, foram transfectados miR mimics de miRNAs com atividade própluripotência, sendo testados miRNAs com mais de 10 alvos na via Notch (miR-92a-3p, miR302c-3p, miR-363-3p) e com menos de 5 alvos (miR-222-3p e miR-371-3p), sendo utilizada a linhagem NTera-2. As condições para transfecção foram as mesmas utilizadas no ítem 3.4, sendo que, após o terceiro dia de transfecção, o meio de cultura foi completamente retirado dos poços e então foram adicionados $100 \mu \mathrm{L}$ de uma suspensão de células OP9-DL1 $\left(5 \times 10^{5}\right.$ células/mL em DMEM contendo 10\% de SFB) por poço. Como controles do ensaio, células transfectadas com PMC foram cocultivas com OP9-Ctrl ou OP9-DL1. No quarto dia de transfecção, onde foram completadas $24 \mathrm{~h}$ de cocultivo, essas células foram fixadas e marcadas de acordo com as condições descritas no item 3.2, sendo utilizados os anticorpos primário anti-OCT4 (Santa Cruz Biotechnology, \#sc-5279, 1:200) e secundário de cabra antiIgG de camundongo conjugado ao Alexa 660 (Life Technologies, \#A21055, 1:300) para identificação das células pluripotentes, e o marcador nuclear Hoechst 33342 para observação de todos os núcleos. As imagens foram adquiridas no sistema de HCS ImageXpress XLS, usando-se a objetiva de 10X e os cubos para detecção de DAPI e Cy5. Essas então foram exportadas para serem analisadas pelo software CellProfiler, sendo identificados somente os núcleos positivos para OCT4 (com a ferramenta de detecção de objetos primários), seguida da quantificação da intensidade de Cy5 nesses objetos. Neste ensaio, busca-se observar o efeito de promoção da pluripotência por inibição da via Notch pelos miRNAs escolhidos, sendo este evidenciado pela observação de uma maior intensidade de OCT4 no grupo transfectado com o 
miR mimic com o efeito esperado em comparação ao grupo controle negativo (transfectado com PMC e cocultivado com OP9-DL1).

Os dados obtidos para cada tratamento foram expressos em porcentagens sobre o controle negativo e esses valores foram comparados entre si utilizando-se o teste estatístico não-paramétrico de Kruskal-Wallis. Para aquele miRNA que apresentou atividade própluripotência via inibição de Notch, foi utilizado o cDNA obtido de células NTera-2 transfectadas com os miR mimics (item 3.8) para avaliação dos níveis de transcritos (por qPCR) de dois componentes da via: NOTCH2 (Hs01050702_m1) e PSEN1 (Hs00997789_m1) e validação do mecanismo de ação. 
4. Resultados 


\subsection{Validação funcional do ensaio para detecção da modulação da pluripotência}

Os resultados obtidos pela análise das fotomicrografias de fluorescência adquiridas das células transfectadas com os miR mimics para miR-302b-3p, miR-29b-3p e PMC se encontram apresentados na Figura 14, podendo ser observadas: a contagem de núcleos, expressa pela porcentagem relativa ao grupo PMC (A); a medida da área celular média em $\mu \mathrm{m}^{2}$ (B); a porcentagem de núcleos positivos para OCT4 $(\mathbf{C})$ e a intensidade média da marcação de OCT4 nos núcleos das células, expressa em porcentagem também relativa ao grupo controle (D).

A

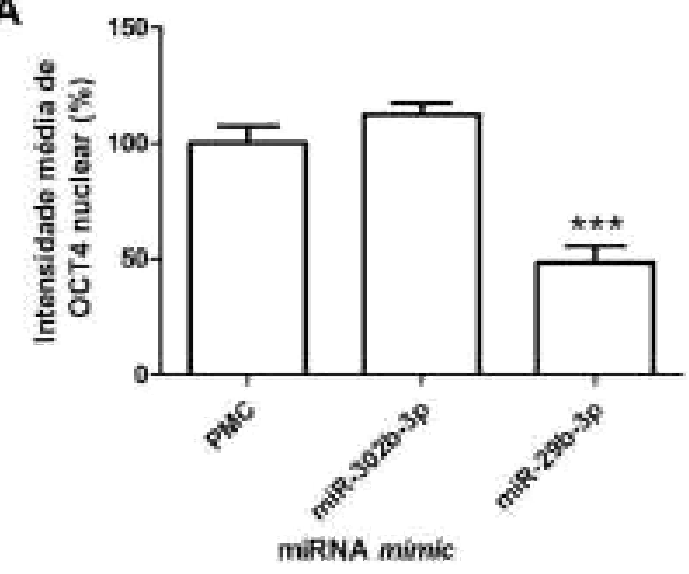

C

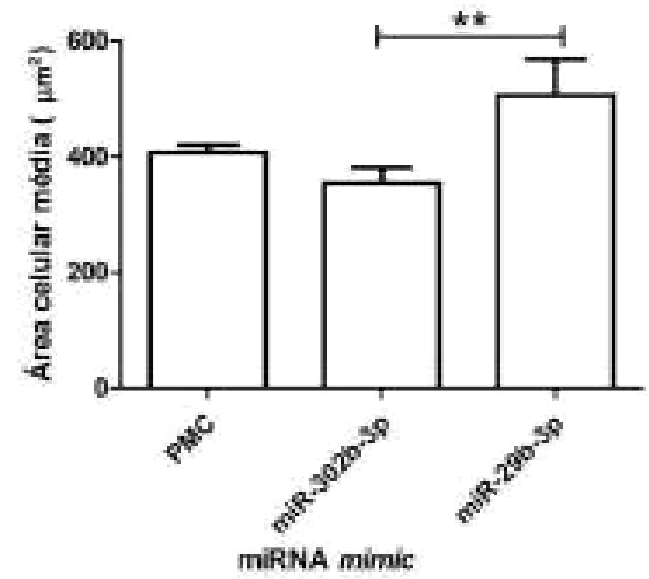

B

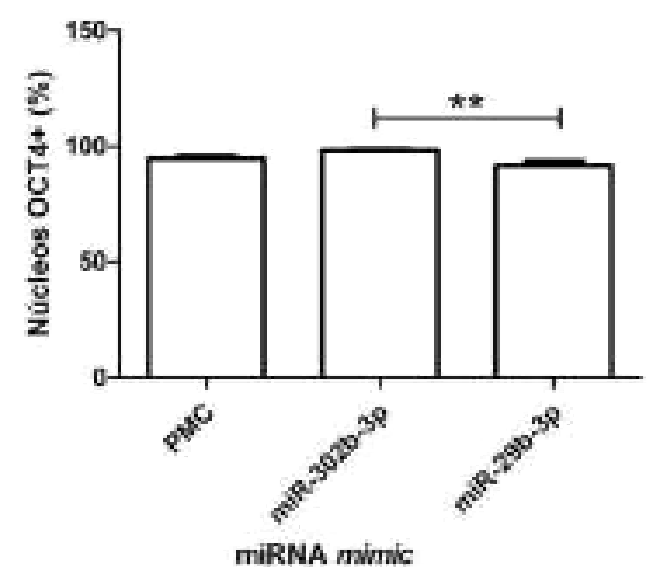

D

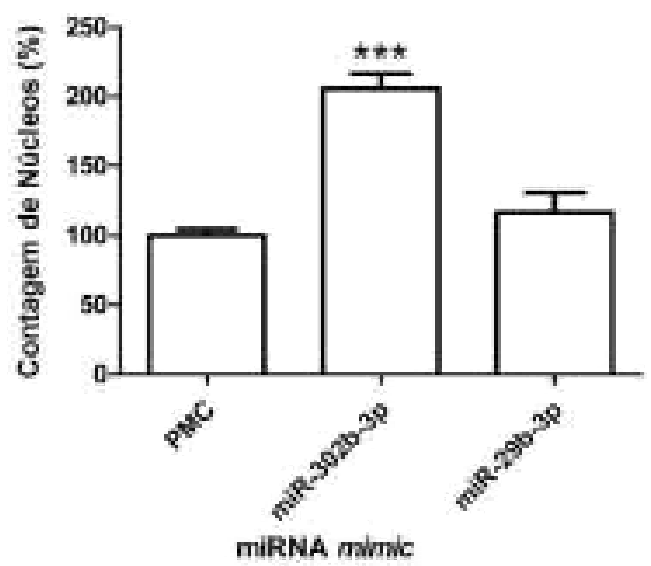

Figura 14. Representações gráficas dos resultados obtidos da transfecção de culturas de células NTera-2 com as moléculas sintéticas miméticas de miR-302b-3p, miR-29b-3p e miR-CTRL (controle; PMC). A) A presença do miR-29b-3p induziu uma redução estatisticamente significativa na quantidade de OCT4 no núcleo, visualizada pela quantificação da intensidade de fluorescência média no canal de FITC; B) As porcentagens de núcleos positivos para a marcação de $O C T 4$ não foram diferentes quando comparados os miRNAs testes com o controle, porém, entre si, foram observadas diferenças significativas, onde o miR-302-3p induziu um aumento, enquanto o miR-29b-3p induziu uma redução na quantidade de núcleos positivos para OCT4; C) As culturas tratadas com o pré-miR-302-3p apresentaram uma área celular significativamente menor do que as tratadas com miR-29b-3p, mas esta diferença não foi visível quando os grupos transfectados com estes miRNAs foram comparados ao grupo PMC. ** valor de $\mathrm{P}<0,01 ; * * *$ valor de $\mathrm{P}<0,0001$. 
Viu-se que o tratamento com o miR-302b-3p não alterou a expressão de OCT4 de forma estatisticamente significativa, porém a transfecção com o miR-29b-3p induziu uma redução de aproximadamente $52 \%(\mathrm{P}<0,0001)$, resultado esperado, já que este miRNA estaria relacionado com a diferenciação celular (STADLER et al., 2010).

A porcentagem de núcleos positivos para OCT4 (OCT4+) não apresentou diferenças estatisticamente significativas entre os grupos tratados com os miRNA mimics e o controle, porém a comparação entre os valores obtidos nos grupos com miR-302b-3p e miR-29b-3p mostrou diferenças significativas $(\mathrm{P}=0,0039)$. Este resultado está de acordo com o esperado, já que uma maior porcentagem de OCT4+ nas células transfectadas com o miR-302b-3p (expresso em células pluripotentes) relaciona-se com uma atividade pró-pluripotência, enquanto o efeito de diminuição dessa porcentagem no grupo de miR-29b-3p se mostra de acordo com seu efeito pró-diferenciação celular. A não observação das diferenças entre os tratamentos e o controle pode ter se dado devido à elevada porcentagem de células OCT4 positivas em condições normais.

Resultado semelhante ao anterior foi observado nas medidas da área celular após a transfecção com miR-302b-3p e miR-29b-3p. A redução na área induzida pelo miRNA relacionado à pluripotência e o aumento desta causada pelo miRNA relacionado à diferenciação celular não apresentaram diferenças estatisticamente significativas comparados ao controle, porém esta diferença foi significativa ao se confrontar os resultados obtidos nas culturas que receberam os miRNAs antagônicos $(\mathrm{P}=0,0096)$.

Com relação à contagem de núcleos, foi possível observar que a transfecção com o miR-302b-3p levou a um aumento significativo no número de células $(\mathrm{P}=0,0009)$. Mais uma vez, este dado se encontra de acordo com o esperado, já que este miRNA é encontrado em elevadas taxas de expressão em células pluripotentes e estas células possuem um ciclo celular encurtado, o que resulta numa maior taxa proliferativa.

\subsection{Perfis fenotípicos induzidos por miRNAs em células-tronco pluripotentes humanas}

Uma vez que ambas as linhagens de células pluripotentes humanas foram transfectadas com cada um dos miR mimics selecionados, passaram pelo processo de marcação para obtenção das imagens de fluorescência e foram estudadas quanto às modificações fenotípicas (baseadas na citomorfologia e expressão de OCT4 e CCNB1) sofridas aprós o tratamento. Esses dados quantitativos foram analisados e organizados para a 
obtenção de perfís fenotípicos induzidos pelo ganho de função dos diferentes miRNAs nas células.

Diversos foram os parâmetros analisados, mas, para a caracterização do perfil fenotípico induzido por cada miRNA e posterior clusterização pelas similaridades de fenótipo apresentadas, foram escolhidos os seguintes parâmetros: contagem de células; solidez, excentricidade, área e perímetro celular e nuclear; e intensidade mediana de OCT4 e CCNB1 no núcleo e citoplasma. Os tamanhos do núcleo e da célula são medidos pelas quantificações de área, que é número de píxels dentro de uma região determinada, e perímetro, o total de píxels ao redor dos limites de uma região determinada. A solidez mede a convexidade e a presença de reentrâncias no objeto, tendo um objeto completamente sólido um valor de solidez igual a 1, enquanto objetos com reentrâncias (limites externos irregulares) apresentam valores menores que 1. Já para a excentricidade, é avaliado o quão elíptico é o objeto, sendo totalmente circulares aqueles com um valor de excentricidade igual a 0 , e objetos com valores superiores são crescentemente elípses mais alongadas, sendo com valor de 1 um segmento em forma de linha. Assim, solidez e excentricidade avaliam a complexidade da morfologia celular, sendo muitas vezes de valores inversamente proporcionais. Já os valores de intensidade para as proteínas marcadas por imunofluorescência são relacionados às quantidades destas nas regiões determinadas, onde quanto maior for a intensidade de fluorescência, maior será a quantidade de proteína.

Como demonstrado nos esquemas das placas para transfecção nas linhagens NTera-2 e H1, cada placa possuia seus próprios controles, tanto que a normalização por POC foi realizada por placa, de forma evitar o efeito de possíveis variações entre as placassobre os resultados observados. Nas Figuras 15 a 18, podem ser visualizados os efeitos de cada um dos tratamentos controles sobre as células, sendo que os resultados foram todos de acordo com o esperado. Para a linhagem NTera-2, vê-se que o tratamento com atRA e com o esiRNA-OCT4 não alterou de forma significativa a contagem de células, porém, como esperado, houve uma grande redução no número de células nos poços transfectados com o siRNA-UBC ( 97\%), molécula esta que tem efeito citotóxico quando internalizada pela célula e liberada no citoplasma (15A), servindo de controle para avaliação da eficiência de transfecção. Com relação ao tamanho das células (15B), somente as transfecções com esiRNA-OCT4 e siRNA-UBC levaram a um aumento ná área celular $(\sim 15 \%$ e $\sim 111 \%$, respectivamente). Já quanto à intensidade de OCT4 nuclear (15C), nota-se que, quando comparados ao grupo controle negativo, todos os tratamentos levaram a uma redução estatisticamente significativa $(\mathrm{P}<0,05)$, sendo as maiores reduções causadas pelo esiRNA- 
OCT4 ( 44\%) e siRNA-UBC ( 53\%), que não diferiram significativamente entre si. A redução causada pelo siRNA-UBC se deve ao estresse causado pela toxicidade do siRNA e não por um knockdown dos transcritos de OCT4, ou redução indireta causada pela diferenciação induzida por atRA.

Os resultados obtidos em ambas as linhagens foram bem similares, mas algumas diferenças foram notadas, como na contagem de células, onde somente se notou uma redução no número de células de NTera-2 tratada com siRNA-UBC, enquanto na linhagem H1 foi observada esta diminuição no grupo siRNA-UBC ( 87\%) e também no grupo esiRNA-OCT4 $(\sim 26 \%)$ (15D). Os resultados concernentes à área celular foram concordantes entre as duas linhagens, sendo que houve um aumento significativo na área celular das CTE tratadas com o esiRNA-OCT4 ( 21\%) e siRNA-UBC ( 119\%) (15E). Também foram concordantes os resultados encontrados para quantificação de OCT4 nuclear, sendo que todos os tratamentos levaram a uma redução nesta, sendo o efeito observado na transfecção com o esiRNA-OCT4 na H1 mais brando na linhagem de CCE (15F).

Este conjunto de resultados demonstra a rebustez dos ensaios para detectação acurada de alterações fenotípicas relacionadas à modulação do fenótipo pluripotente, tanto na linhagem NTera-2 quanto na H1. Ao realizar a clusterização fenotípica baseada nos parâmetros quantitativos citados anteriormente, resultantes das análises de fotomicrografias (como as apresentadas nas Figuras 16 e 17 a seguir) dos diferentes controles, mostrou-se que, apesar de diferenças notadas entre as duas placas que fazem parte de cada ensaio, os tratamentos iguais se agrupam (Figura 18), reafirmando a eficiência do ensaio. Assim, este ensaio foi então empregado para avaliação da modulação da pluripotência pelos miRNAs.

Dos 31 miRNAs testados, 25 apresentaram resultados concordantes entre ambas linhagens (em relação a expressão de OCT4), onde 16 tiveram um efeito pró-pluripotência e 9, pró-diferenciação. Dos outros 6 discordantes, 5 induziram diferenciação na linhagem NTera-2, mas não na H1, e 1 teve o efeito contrário (Figura 19A). Ao comparar os resultados obtidos do ensaio funcional com o esperado (Tabela 01, ítem 3.4), vê-se, que dentre os 25 miRNAs com efeitos concordantes em NTera-2 e H1, 20 apresentaram efeito compatível com a literatura (13 pró-pluripotência e 7 pró-diferenciação celular) e outros 5 se comportaram de forma discordante (Figura 19B). Para melhor visualização e entendimento da avaliação fenotípica nas linhagens de CCE e CTE, a descrição dos resultados obtidos para cada linhagem se encontram apresentados nos dois subtópicos a seguir. 
A

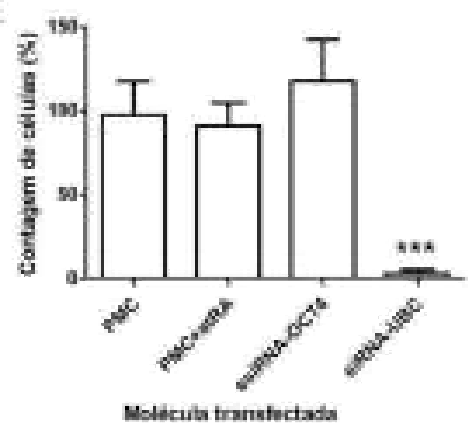

D

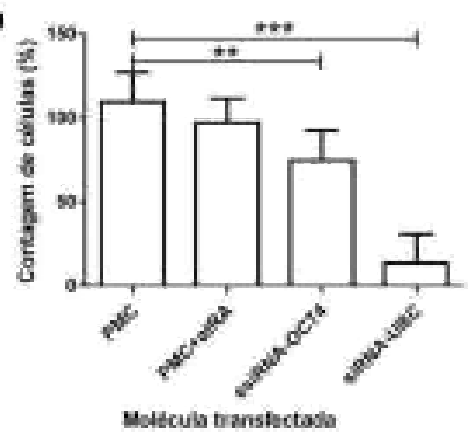

B

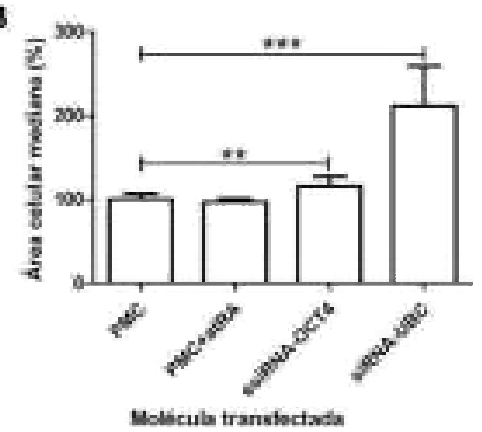

E

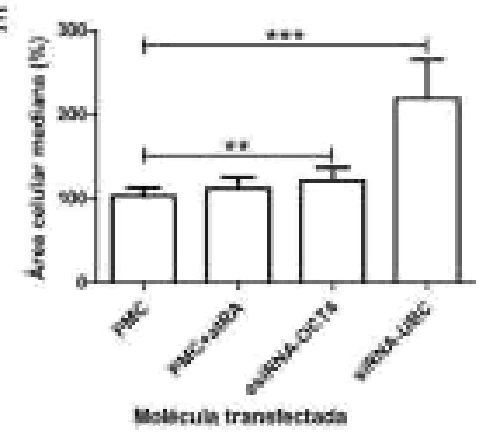

C

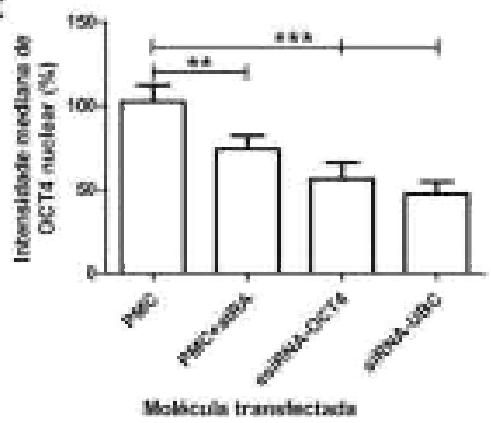

F

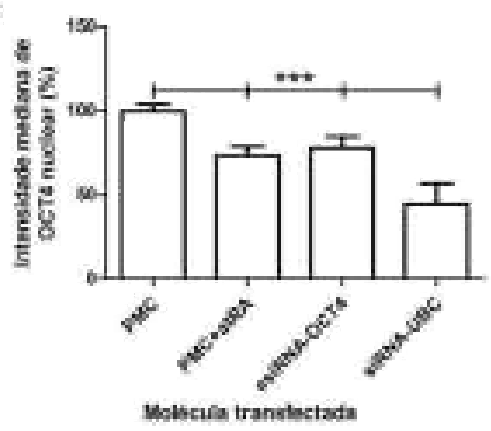

Figura 15. De "A" a "C" estão representados os resultados obtidos na linhagem NTera-2 após tratamento com: miR controle negativo (PMC), PMC seguido de tratamneto com ácido trans-retinóico, esiRNA-OCT4 e siRNAUBC. Os resultados refetenres aos mesmos tratamentos na linhagem H1 se encontram de "D" a "E". O tempo de transfecção para a linhagem NTera-2 foi de 4 dias, sendo o grupo que recebeu atRA mantido em contato com este por 3 dias, enquanto para $\mathrm{H} 1$ o tempo de transfecção foi de 3 dias e de tratamento com atRA de 2 dias. A e D) A transfecção com o siRNA-UBC levou a uma redução significativa do número de células, tanto para a linhagem H1 quanto para NTera-2, enquanto o esiRNA-OCT4 também reduziu o número de células H1 após a incubação. B) $\mathrm{O}$ tratamento com atRA não alterou significativamente a área das células, enquanto os esiRNAOCT4 e siRNA-UBC levaram a um aumento estatisticamente significativo no tamanho celular, tanto para H1 quanto para NTera-2. C) Em ambas as linhagens celulares, todos os tratamentos levaram a uma redução significativa nos níveis de OCT4 nuclear. $* *=\mathrm{P}<0,01, * * *=\mathrm{P}<0,0001$ 


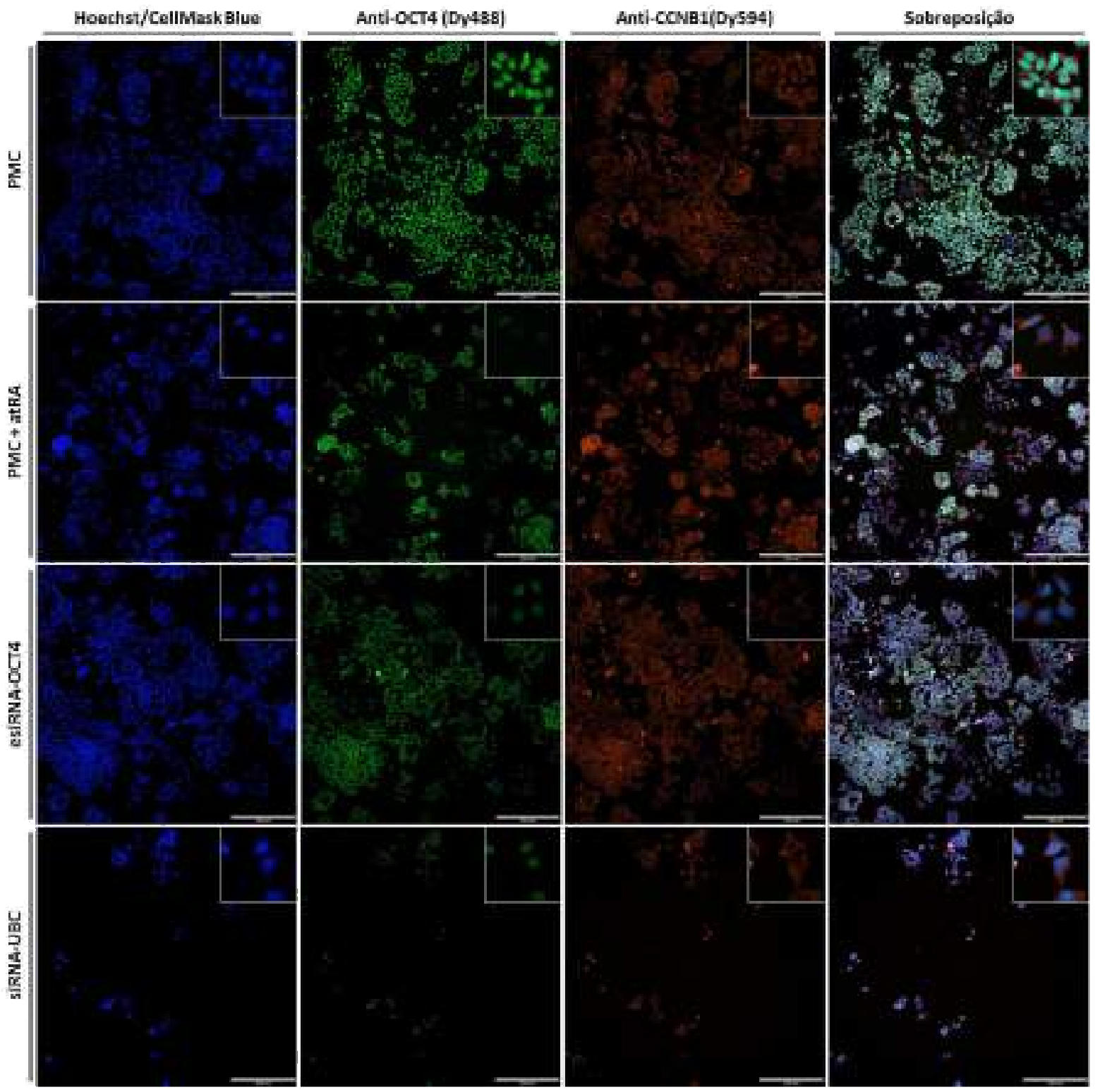

Figura 16. Fotomicrografias da linhagem NTera-2 marcada com Hoechst 33342 e CellMask®Blue (azul), antiOCT4 (verde) e anti-CCNB1 (laranja) após transfectadas com miR controle negativo (PMC), esiRNA-OCT4, siRNA-UBC e também após o tratamento com atRA $(10 \mu \mathrm{M})$. Essas células foram mantidas em cultura por 4 dias após a transfecção, e o grupo PMC+atRA tratado com o indutor de diferenciação por 3 dias. Com o fim da incubação, as células foram fixadas, marcadas e imageadas, para então serem analisadas por meio do CellProfiler para a aquisição dos dados quantitativos que deram origem ao perfil fenotípico de cada tratamento. É possível notar a alta expressão de OCT4 nas células de PMC pela grande quantidade de verde no núcleo. Todos os tratamento causaram uma redução nesta marcação. Alguns outros efeitos como aumento da área celular e diminuição do número total de células também podem ser notados, sendo que esta diminuição foi somente no tratamento com o siRNA citotóxico contra UBC. 


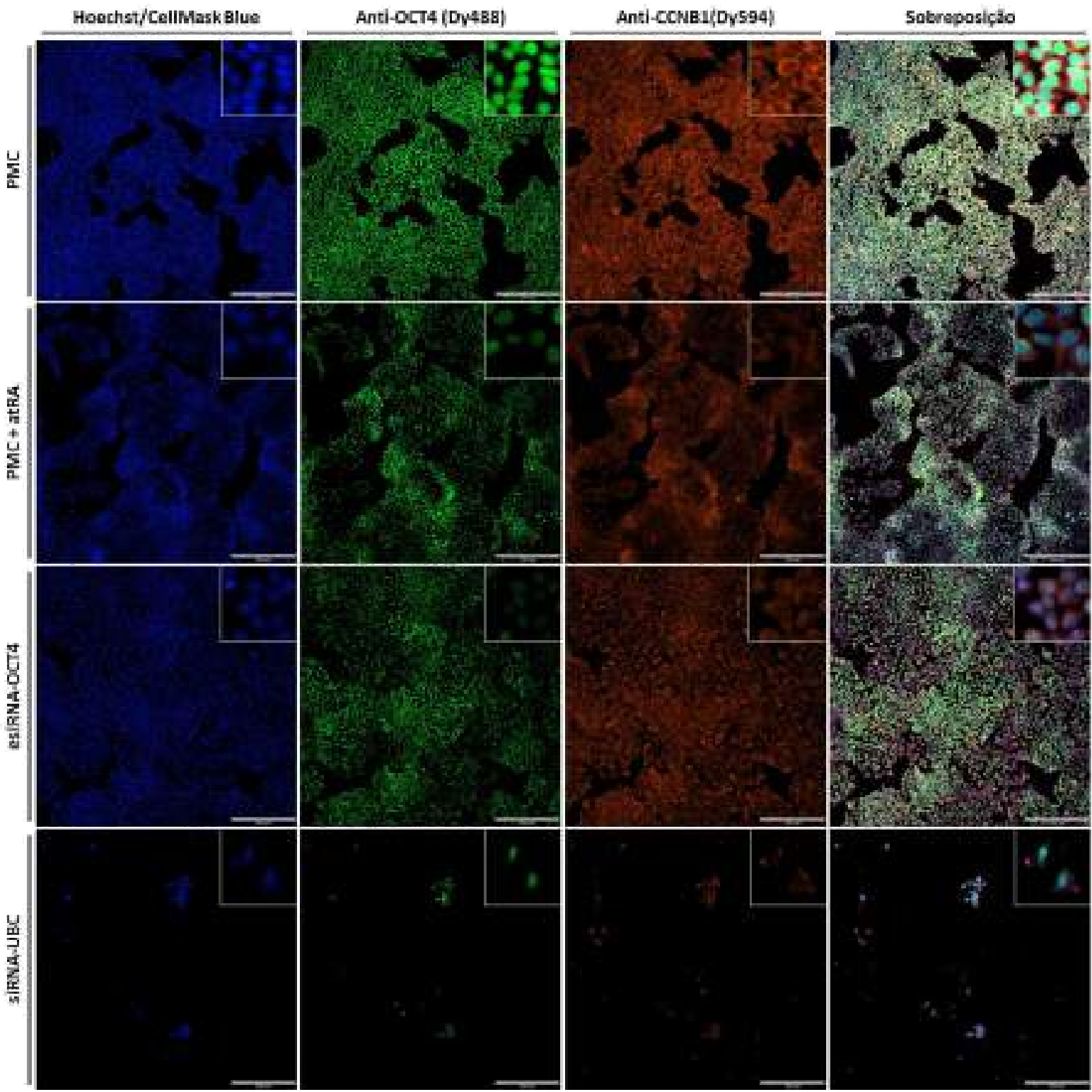

Figura 17. Fotomicrografias da linhagem H1 marcada com Hoechst 33342 e CellMask ${ }^{\circledR B l u e}$ (azul), anti-OCT4 (verde) e anti-CCNB1 (laranja) após transfectadas com miR controle negativo (PMC), esiRNA-OCT4, siRNAUBC e também após o tratamento com atRA $(10 \mu \mathrm{M})$. Essas células foram mantidas em cultura por 3 dias após a transfecção, e o grupo PMC+atRA tratado com o indutor de diferenciação por 2 dias. Com o fim da incubação, as células foram fixadas, marcadas e imageadas, para então serem analisadas por meio do CellProfiler para a aquisição dos dados quantitativos que deram origem ao perfil fenotípico de cada tratamento. É possível notar a alta expressão de OCT4 nas células de PMC pela grande quantidade de verde no núcleo e como os outros tratamentos reduziram esta marcação. Alguns outros efeitos como aumento da área celular e diminuição do número total de células também podem ser notados, particularmente mais evidentes na figura representativa do grupo tratado com o siRNA-UBC. 


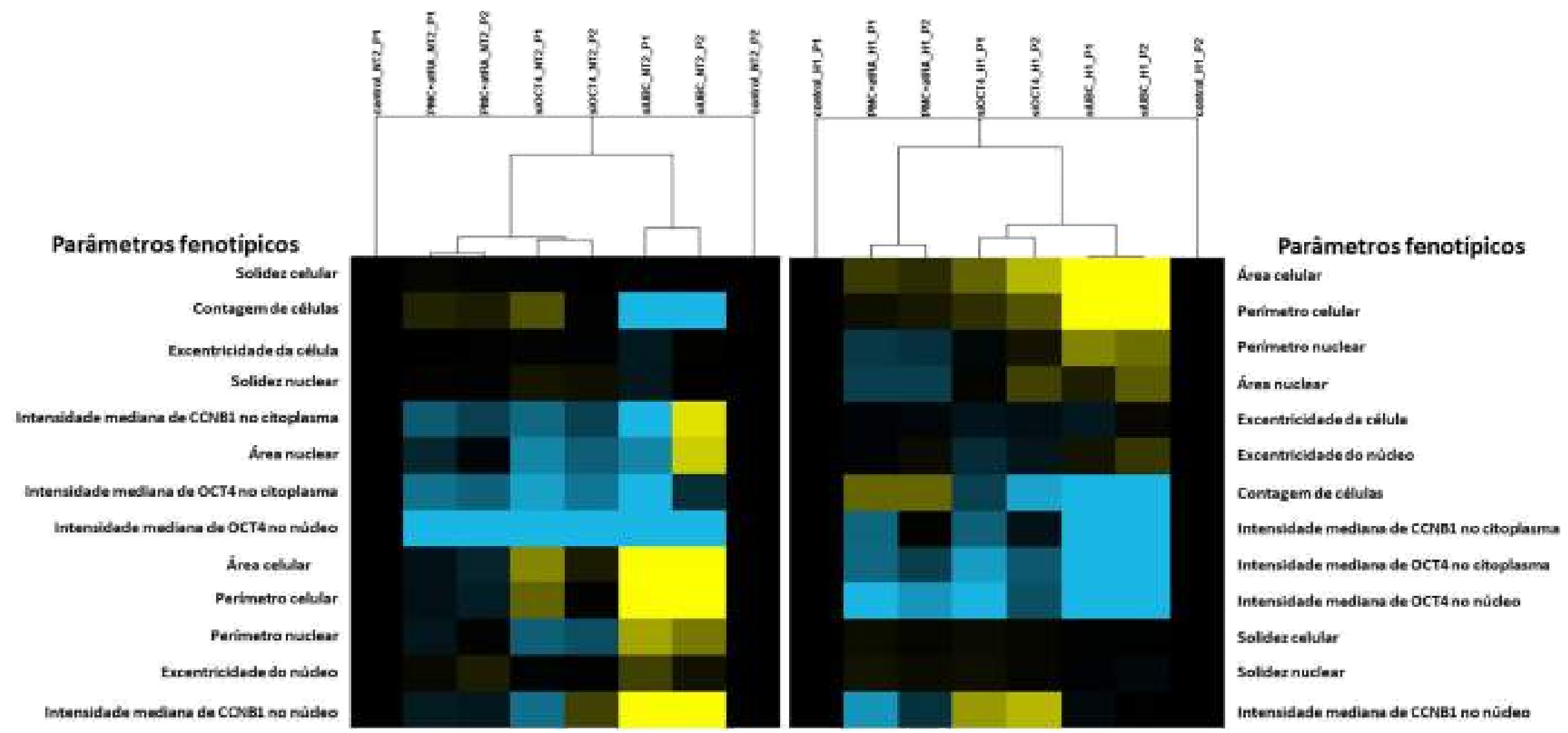

Figura 18. Clusterização realizada a partir da avaliação dos efeitos fenotípicos induzidos por cada tratamento controle (PMC, PMC+atRA, esiRNA-OCT4 e siRNA-UBC) nas duas placas diferentes (P1 e P2) que constituiam os ensaios para estudas os miRNAs selecionados nas duas linhagens pluripotentes, NTera-2 (NT2, figura à esquerda) e H1 (figura à direita). Essas clusterizações foram realizadas baseando-se nos dados quantitativos da análise de imagens de fluorescência, por meio do CellProfiler, utilizando um conjunto de 13 parâmetros para definir o perfil fenotípico de cada tratamento. No heatmap, onde azul brilhante representa o menor valor, amarelo brilhante o maior e preto o valor central (do PMC), são apresentas as medidas relativas dos traços fenotípicos selecionados, resultantes da normalização de cada tratamento pelo controle negativo (PMC) com o uso de ferramentas do KNIME. Nota-se que os mesmos tratamentos realizados nas duas diferentes placas se agruparam de acordo com as características apresentadas, demonstrando assim a robustez do ensaio, bem como sua capacidade de identificar alterações na morfologia e expressão de OCT4 e CCNB1 induzidas por tratamentos com moléculas com ação similar sobre as células pluripotentes. 

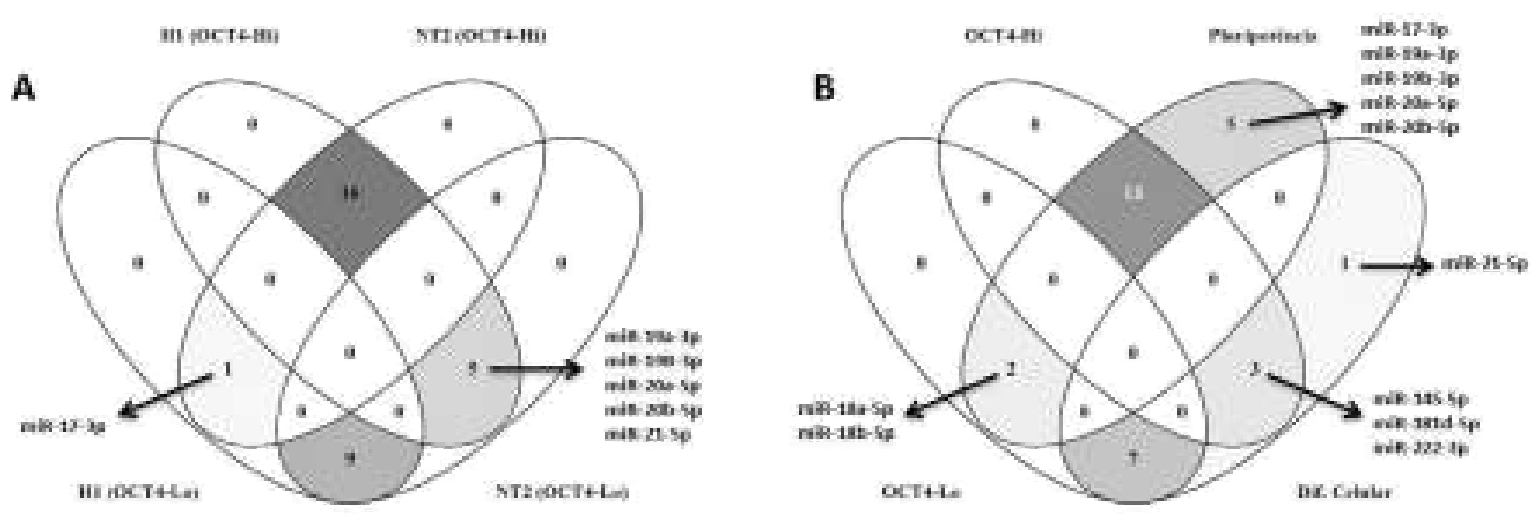

Figura 19. Os diagramas de Venn apresentados aqui representam a comparação dos ensaios funcionais em NTera-2 (NT2) e H1 (A), e entre os resultados observados com as transfecções e o esperado, baseado na literatura científica (B). Para confecção dos diagramas, foi utilizada a ferramenta Venny 2.1 (http://bioinfogp.cnb.csic.es/tools/venny/) A) Baseando-se na intensidade de fluorescência nuclear mediana para OCT4, os miRNAs foram classificados como pró-pluripotência, induzindo o aumento de OCT4 (OCT4Hi[High]), e pró-diferenciação celular (OCT4-Lo[Low]). Dos 31 miRNAs testados, 25 apresentaram resultados concordantes entre as duas linhagens de células pluripotentes humanas, sendo 16 indutores de um fenótipo pluripotente e 9, de diferenciação. B) Os 25 miRNAs que apresentaram efeitos concordantes em NT2 e H1 tiveram sua atividade funcional comparada com o esperado. Daqueles com atividade pró-pluripotência (OCT4Hi), 13 se comportaram congruentemente ao esperado, e dos 9 com efeito pró-diferenciação, 7 se enquadraram com o expectável.

\subsubsection{Alterações fenotípicas induzidas por miRNAs na linhagem NTera-2}

De acordo com os perfís apresentados, os miRNAs foram divididos em dois grandes clusters, sendo eles cluster A e cluster B (Figura 20). As principais características responsáveis pela formação destes dois clusters são baseadas na expressão do marcador de pluripotência e da ciclina B1, tanto no núcleo quanto no citoplasma da célula. Os miRNAs presentes no cluster A levaram a uma diminuição na intensidade de fluorescência destas marcações, resultado condizente com perda de pluripotência, sendo o miR-17-3p o único que não induziu uma diminuição aparente, de fato apresentando uma maior quantidade de OCT4 nuclear que o grupo controle. Já os miRNAs do cluster B mostraram um efeito inverso, com uma notável elevação nas quantificações de OCT4 e CCNB1 no núcleo e citoplasma, efeito este que pode ser relacionado com uma atividade pró-pluripotência. Em linha, todos os diferentes miR-302 (a, b, c, d), utilizados no presente estudo, que são sabidamente relacionados com a manutenção do estado indiferenciado de células pluripotentes, se encontraram neste cluster. 


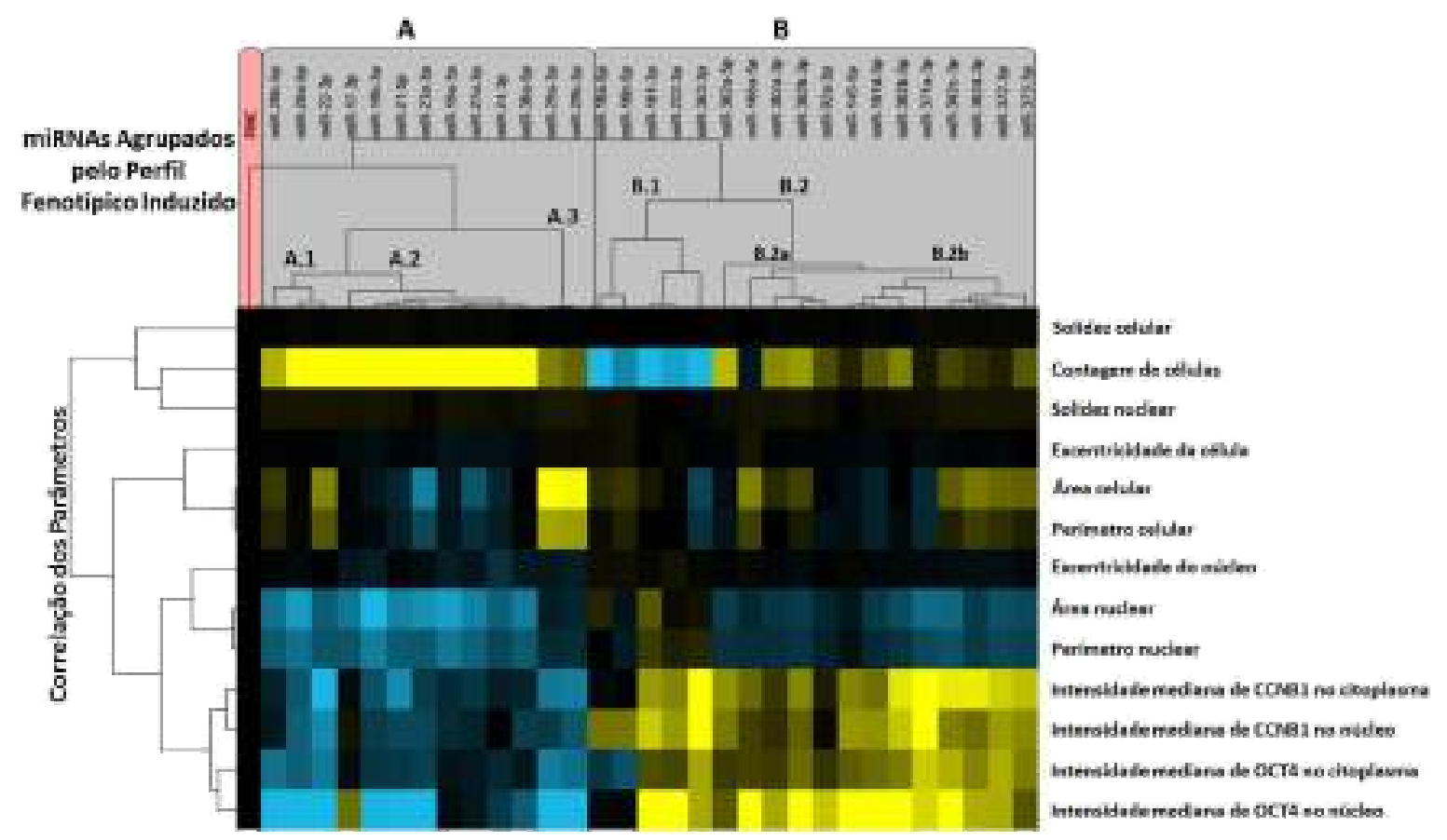

Figura 20. Clusterização dos miRNAs pelos seus efeitos fenotípicos na linhagem NTera-2, baseando-se em dados quantitativos da análise de imagens de fluorescência, por meio do CellProfiler, de células transfectadas com miR mimics e controle negativo. No heatmap, onde azul brilhante representa um menor valor, amarelo brilhante representa um maior e preto seria o valor central, são apresentas as medidas relativas dos traços fenotípicos selecionados, resultantes da normalização de cada tratamento pelo controle negativo (PMC) com o uso de ferramentas do KNIME. De acordo com os perfis induzidos por cada miRNA, foram identificados dois grandes clusters, sendo o cluster A formado por miRNAs que induziram diferenciação celular e o cluster $\mathrm{B}$, por aqueles que promoveram características de pluripotência. Estes clusters ainda foram subdivididos de acordo, principalmente, com as semelhanças e diferenças morfológicas observadas em cada tratamento.

Esses dois grandes clusters ainda foram subdivididos, principalmente, de acordo com as variações morfológicas induzidas pelos diferentes miRNAs que os constituem. O cluster A foi subdividido em A.1, A.2 e A.3, enquanto o B, em B.1, B.2a e B.2b. O subcluster A.1, composto pelos miR-20a-5p, miR-20b-5p e miR-22-3p, diferiu dos subclusters A.2 e A.3 principalmente por induzirem um aumento na área celular, mas sem alterar de forma muito intensa a complexidade celular, sendo que estas apresentaram uma menor excentricidade e uma maior solidez do que aquelas dos outros subclusters. A principal característica do subcluster A.2 é a diminuição da marcação de OCT4 e CCNB1 sem indução de aumento na área e complexidade celular, sendo constituído pelos miR-17-3p, miR-19a-3p, miR-19b-3p, miR-21-5p, miR-23a-3p, miR-24-3p, miR-27a-3p e miR-30a-5p. Por fim, o aumento acentuado da área celular, bem como da complexidade das células, induzido pelos miR-29a$3 p$ e miR-29b-3p fez com que estes se agrupassem isoladamente dos demais miRNAs que induziram diferenciação, formando assim o subcluster A.3.

Quanto ao cluster de miRNAs que se mostraram como positivamente relacionados com a pluripotência, a formação dos diferentes subclusters também se mostrou relacionada 
com as características morfológicas apresentadas por estes. Começando pelo subcluster B.1, formado pelos miR-18a-5p, miR-18b-5p, miR-101-3p, miR-222-3p e miR-363-3p, este diferiu do subcluster B.2 principalmente pela menor contagem de células, mas também por maiores áreas e perímetros nucleares, sendo que os dois primeiros miRNAs citados ainda não mostraram um aumento expressivo nas quantificações de OCT4 citoplasmático e nuclear, e de CCNB1 citoplasmática, permanecendo muito próximos ao grupo controle negativo. Os componentes deste subcluster também apresentaram um leve aumento na complexidade celular, assim como na área e complexidade dos núcleos. O subcluster B.2, por sua vez, ainda foi subdividio em B.2a e B.2b, sendo os miR-92a-3p, miR-106a-5p, miR-302a-3p, miR-302a$5 p$ e miR-302b-3p os representantes do primeiro (embora o miR-302a-5p seja, na verdade, um ramo independente, com distância equivalente aos clusters B.2a e B.2b) e, do segundo, os miR-145-5p, miR-181d-5p, miR-302b-5p, miR-302c-3p, miR-302d-3p, miR-371a-3p, miR372-3p e miR-373-3p. As diferenças entre esses dois subclusters não são tão evidentes quanto nos outros casos, no entando, nota-se uma maior intensidade nuclear e citoplasmática de ciclina B1 no cluster B.2b.

Os resultados para cada um dos treze parâmetros fenotípicos analisados nas imagens das células da linhagem NTera-2, transfectadas com os diferentes miR mimics, podem ser observados de forma individual nas Figuras 21 a 27, sendo os dados apresentados originados de cada um dos vinte e sete sítios imageados ( 9 por poço, de uma triplicata) para cada grupo de tratamento. Os valores plotados nos gráficos são porcentagens relativas ao grupo transfectado com PMC. 

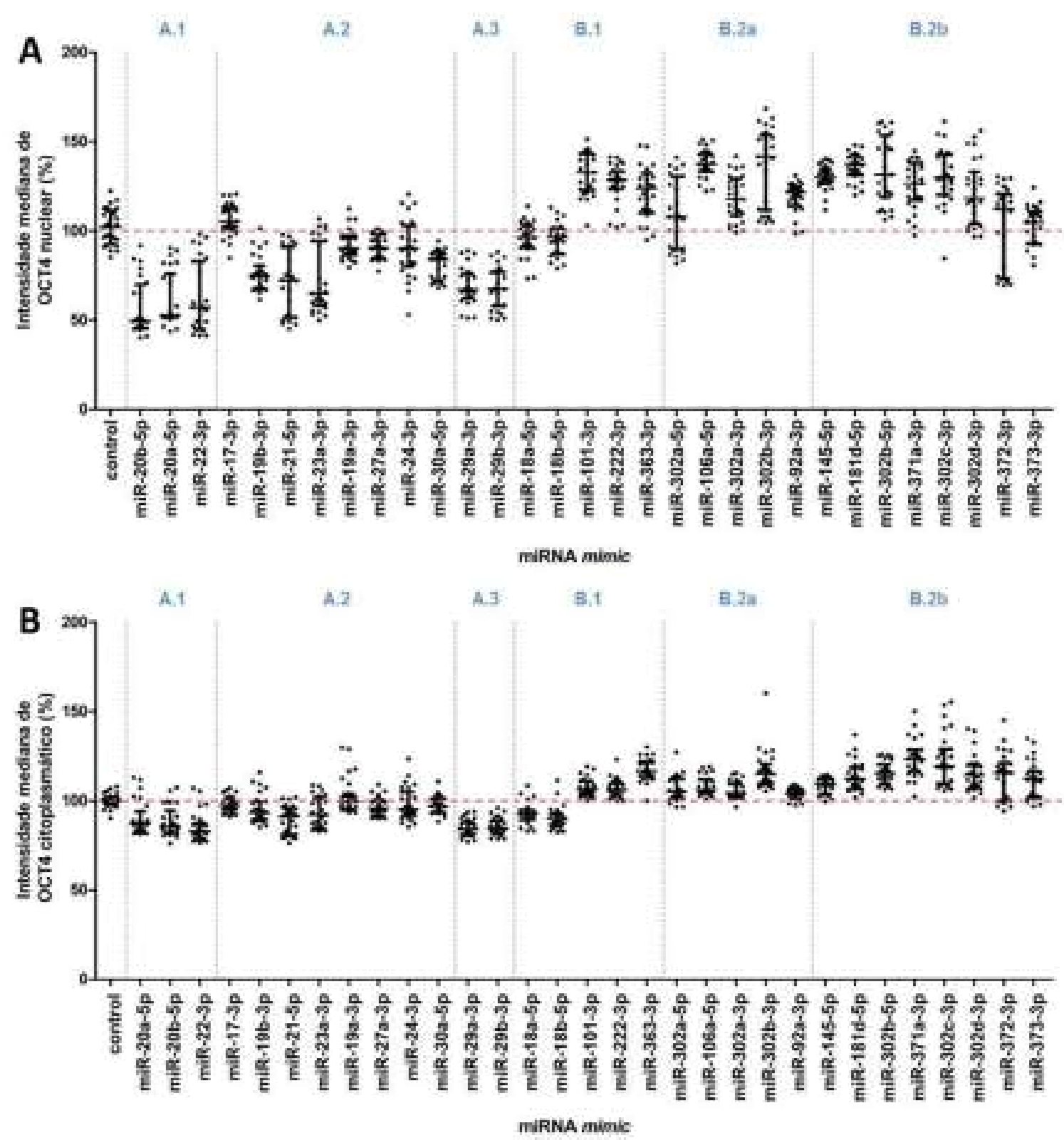

Figura 21. Gráficos de dispersão apresentando os resultados em porcentagem (relativos ao grupo controle negativo) de cada sítio (pontos pretos) das replicatas (poço) de tranfecção com os diferentes miR mimics na linhagem NTera-2. Aqui se encontram apresentados os efeitos destas moléculas sobre as quantificações de OCT4 no núcleo e citoplasma, representadas pelas intensidades medianas de OCT4 nuclear (A) ou citoplasmática (B). A linha tracejada vermelha (na horizontal) representa a mediana do grupo controle, enquanto os clusters de miRNAs, gerados na clusterização fenotípica, se encontram separados pelas listas tracejadas azúis (na vertical). 

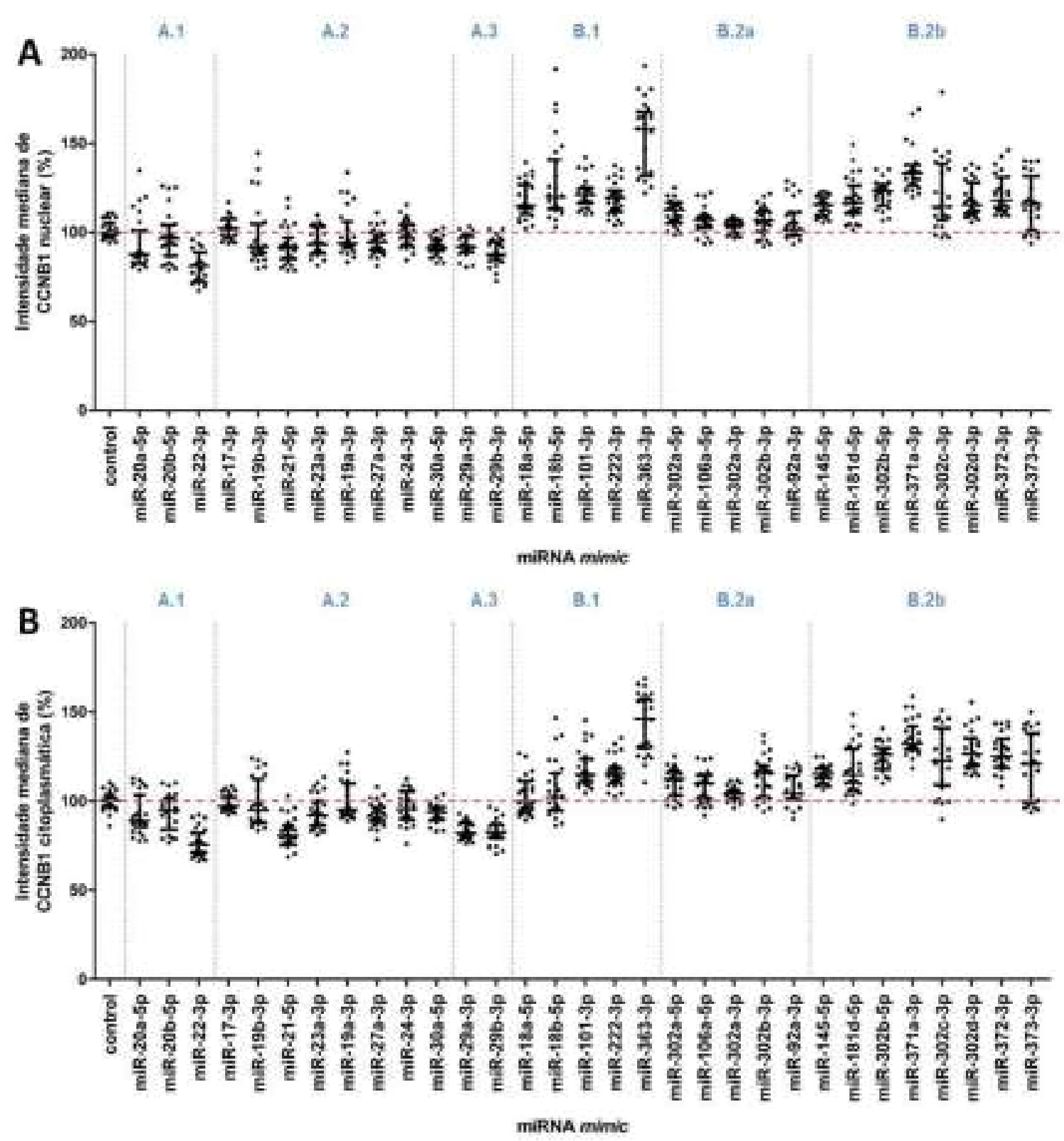

Figura 22. Gráficos de dispersão apresentando os resultados em porcentagem (relativos ao grupo controle negativo) de cada sítio (pontos pretos) das replicatas (poço) de tranfecção com os diferentes miR mimics na linhagem NTera-2. Aqui se encontram apresentados os efeitos destas moléculas sobre as quantificações de CCNB1 no núcleo e citoplasma, representadas pelas intensidades medianas de CCNB1 nuclear (A) ou citoplasmática (B). A linha tracejada vermelha (na horizontal) representa a mediana do grupo controle, enquanto os clusters de miRNAs, gerados na clusterização fenotípica, se encontram separados pelas listas tracejadas azúis (na vertical). 

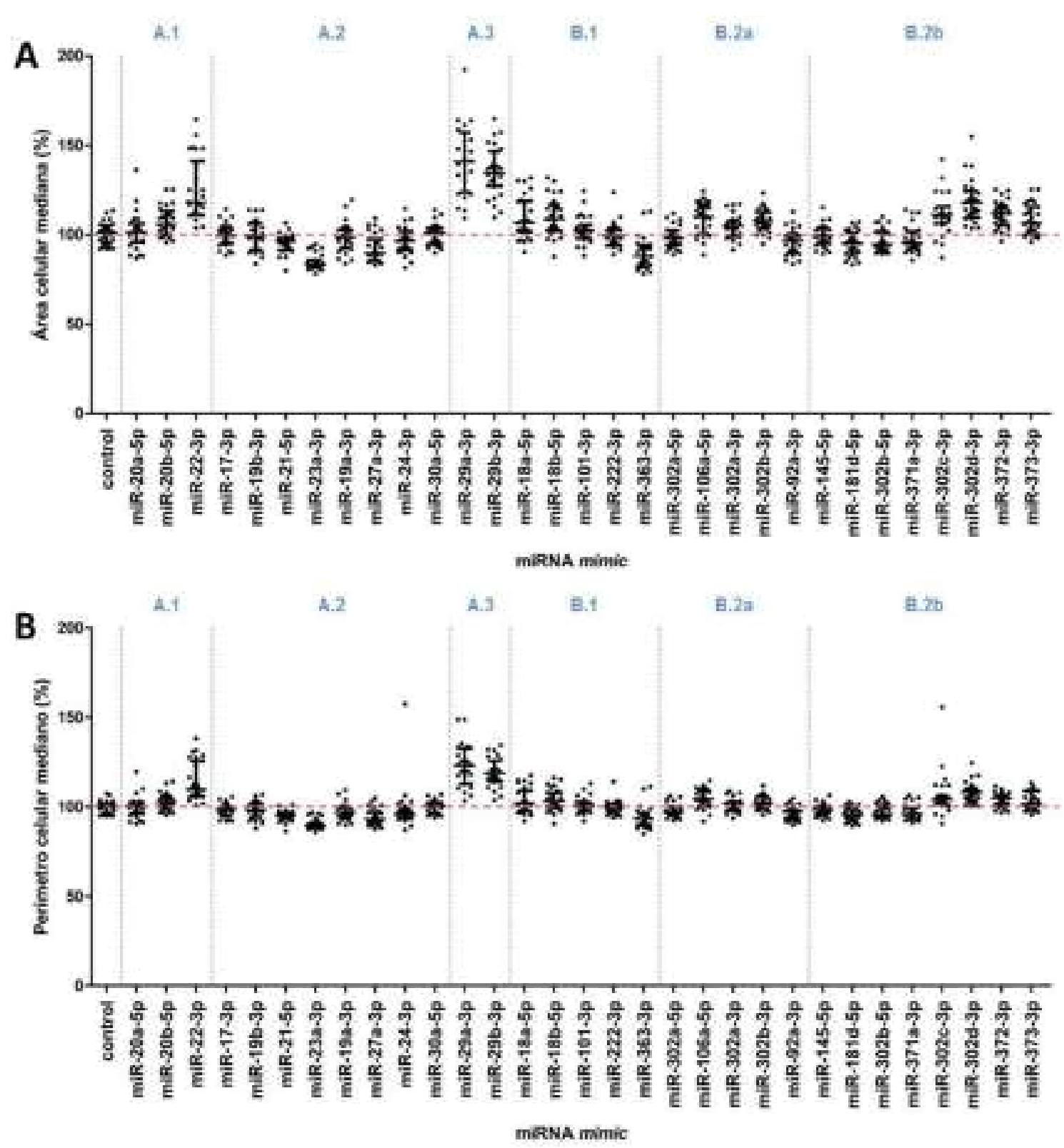

Figura 23. Gráficos de dispersão apresentando os resultados em porcentagem (relativos ao grupo controle negativo) de cada sítio (pontos pretos) das replicatas (poço) de tranfecção com os diferentes miR mimics na linhagem NTera-2. Aqui se encontram apresentados os efeitos destas moléculas sobre o tamanho das células, representados pela área $(\mathbf{A})$ e perímetro (B) celulares medianos. A linha tracejada vermelha (na horizontal) representa a mediana do grupo controle, enquanto os clusters de miRNAs, gerados na clusterização fenotípica, se encontram separados pelas listas tracejadas azúis (na vertical). 


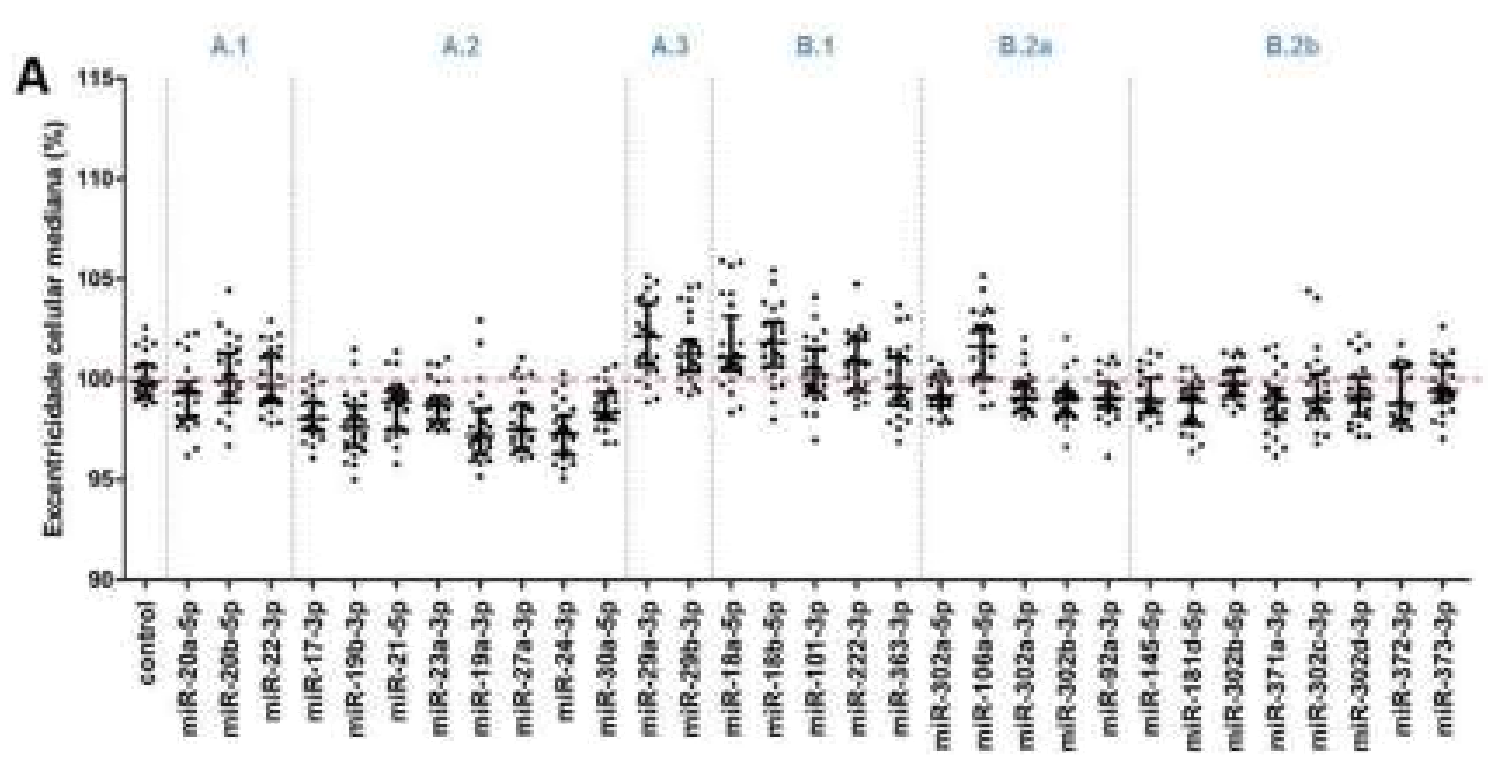

miRNA mimic

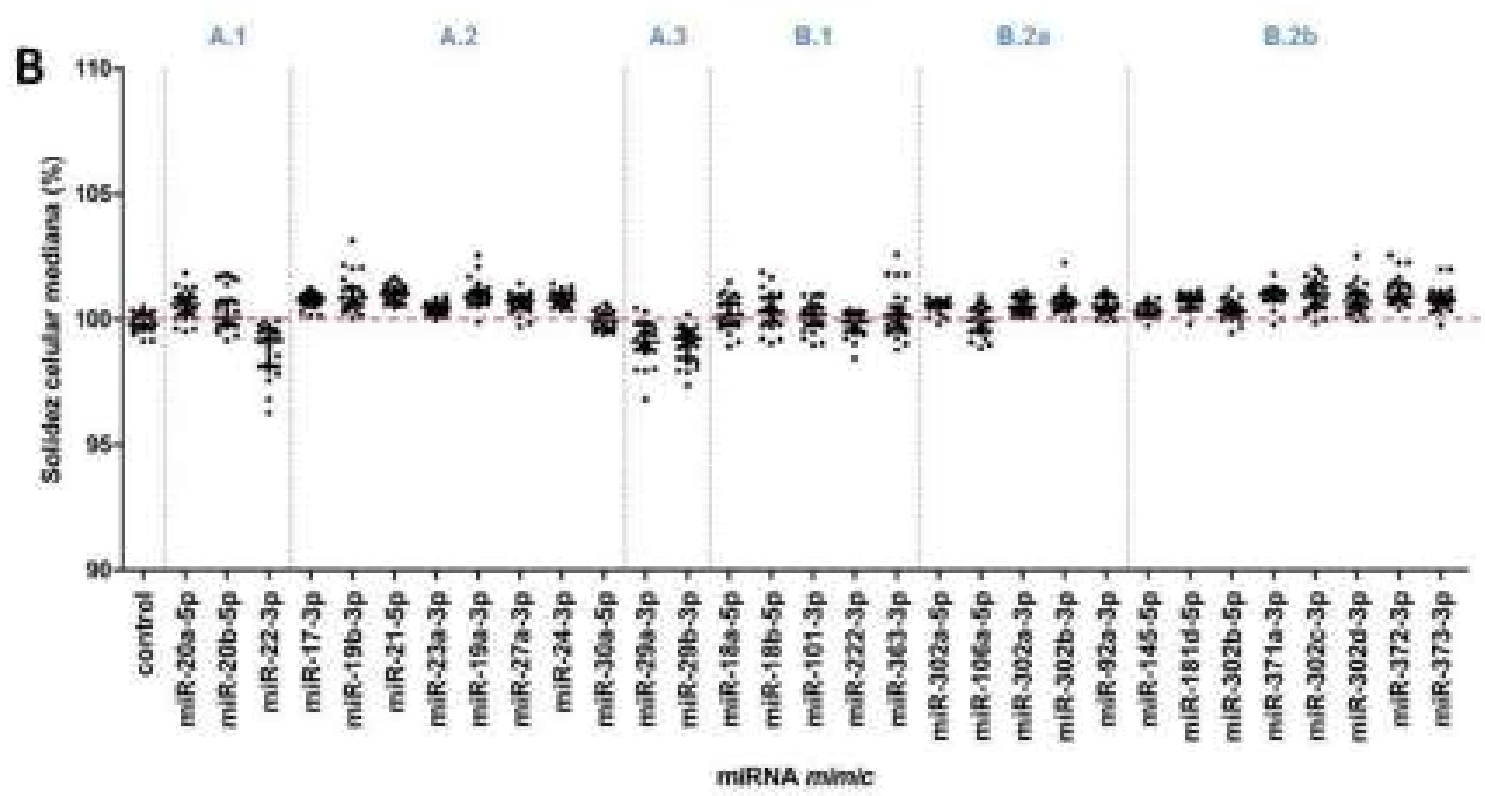

Figura 24. Gráficos de dispersão apresentando os resultados em porcentagem (relativos ao grupo controle negativo) de cada sítio (pontos pretos) das replicatas (poço) de tranfecção com os diferentes miR mimics na linhagem NTera-2. Aqui se encontram apresentados os efeitos destas moléculas sobre a complexidade das células, representados pela quantificação da excentricidade celular (\%) (A) e solidez celular (\%) (B) medianas. A linha tracejada vermelha (na horizontal) representa a mediana do grupo controle, enquanto os clusters de miRNAs, gerados na clusterização fenotípica, se encontram separados pelas listas tracejadas azúis (na vertical). 


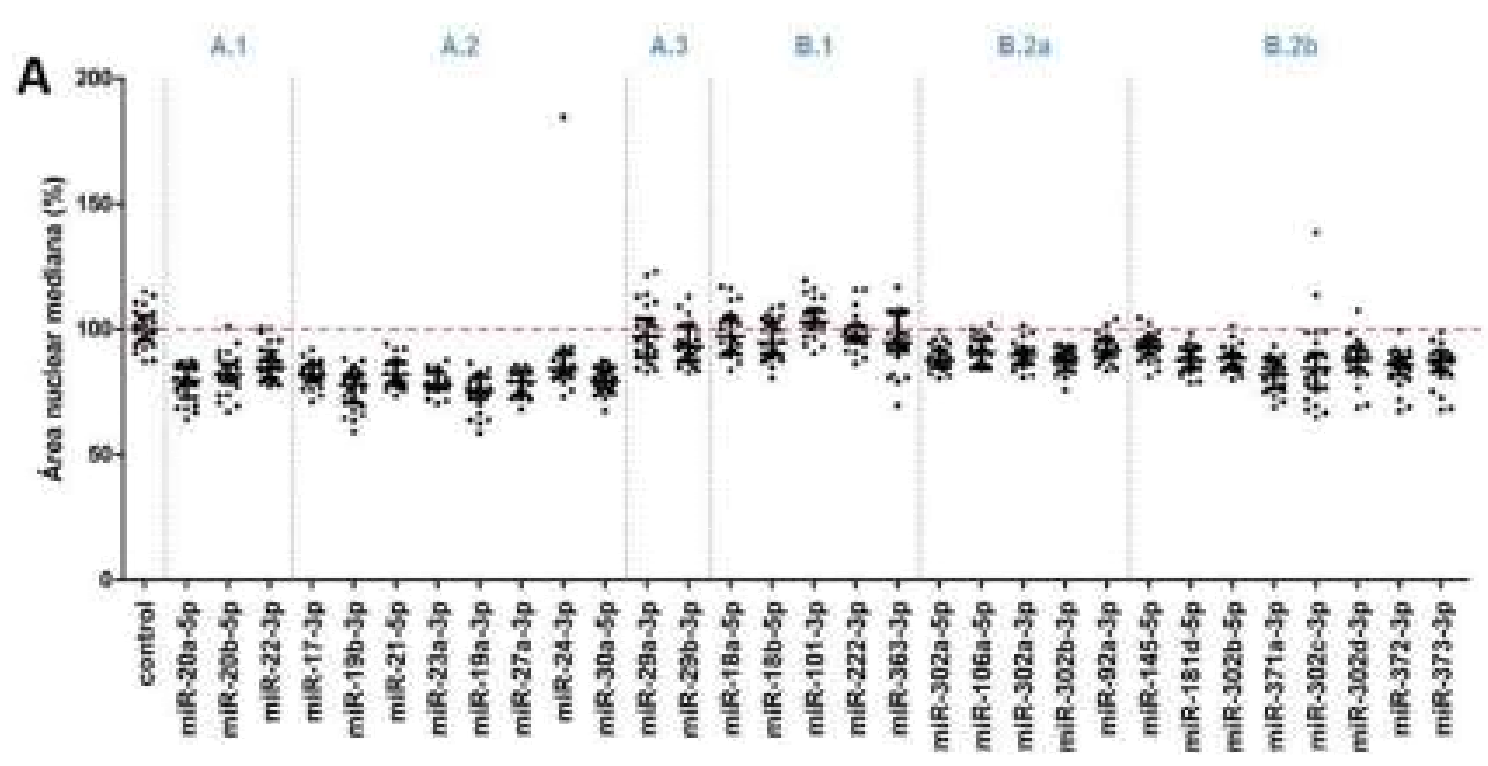

MiRNA mimic

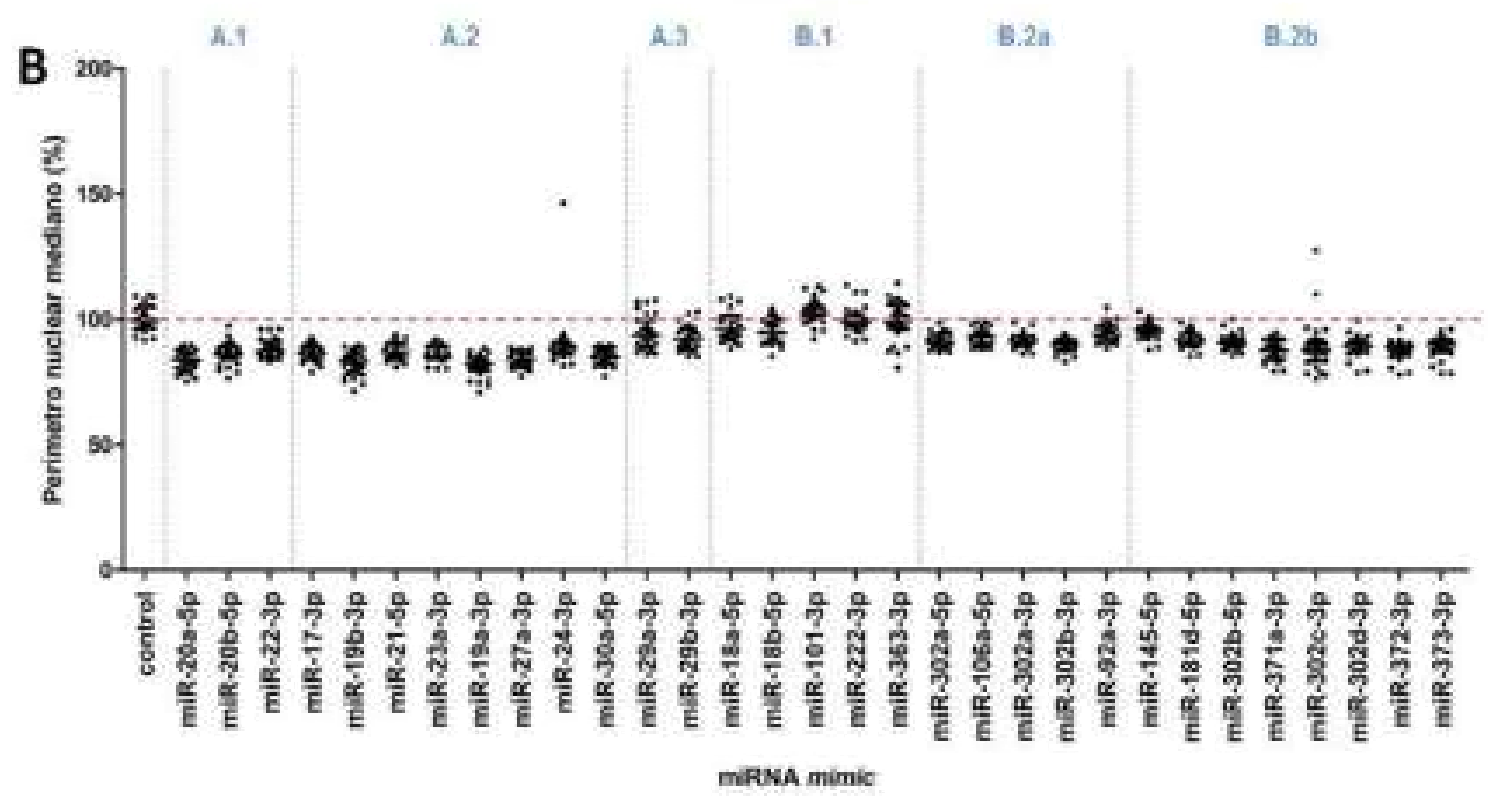

Figura 25. Gráficos de dispersão apresentando os resultados em porcentagem (relativos ao grupo controle negativo) de cada sítio (pontos pretos) das replicatas (poço) de tranfecção com os diferentes miR mimics na linhagem NTera-2. Aqui se encontram apresentados os efeitos destas moléculas sobre o tamanho dos núcleos celulares, representados pela quantificação da área $(\mathbf{A})$ e perímetro (B) nucleares medianos. A linha tracejada vermelha (na horizontal) representa a mediana do grupo controle, enquanto os clusters de miRNAs, gerados na clusterização fenotípica, se encontram separados pelas listas tracejadas azúis (na vertical). 


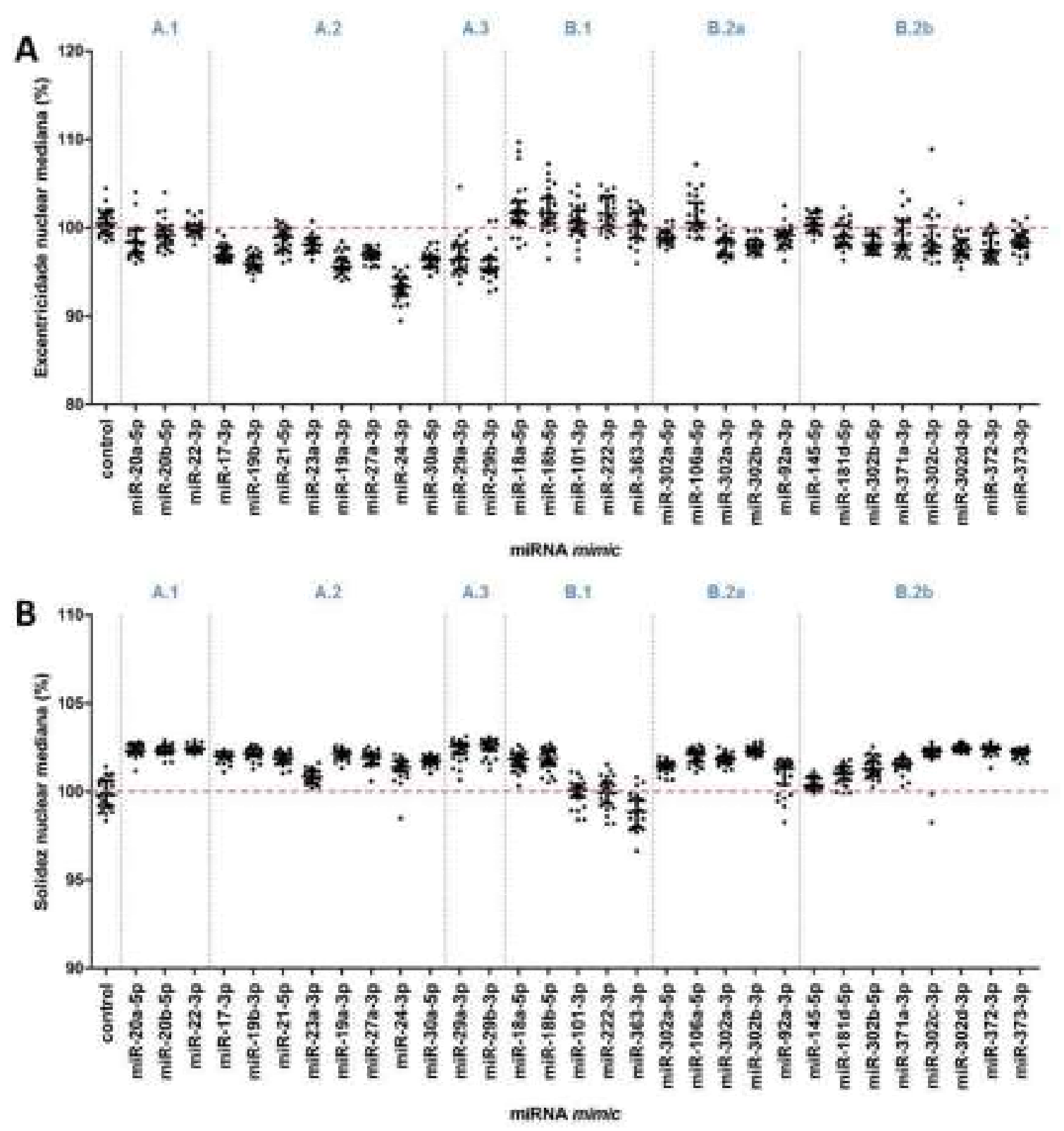

Figura 26. Gráficos de dispersão apresentando os resultados em porcentagem (relativos ao grupo controle negativo) de cada sítio (pontos pretos) das replicatas (poço) de tranfecção com os diferentes miR mimics na linhagem NTera-2. Aqui se encontram apresentados os efeitos destas moléculas sobre a complexidade dos núcleos celulares, representados pela quantificação da excentricidade (A) e solidez (B) nucleares medianas. A linha tracejada vermelha (na horizontal) representa a mediana do grupo controle, enquanto os clusters de miRNAs, gerados na clusterização fenotípica, se encontram separados pelas listas tracejadas azúis (na vertical). 


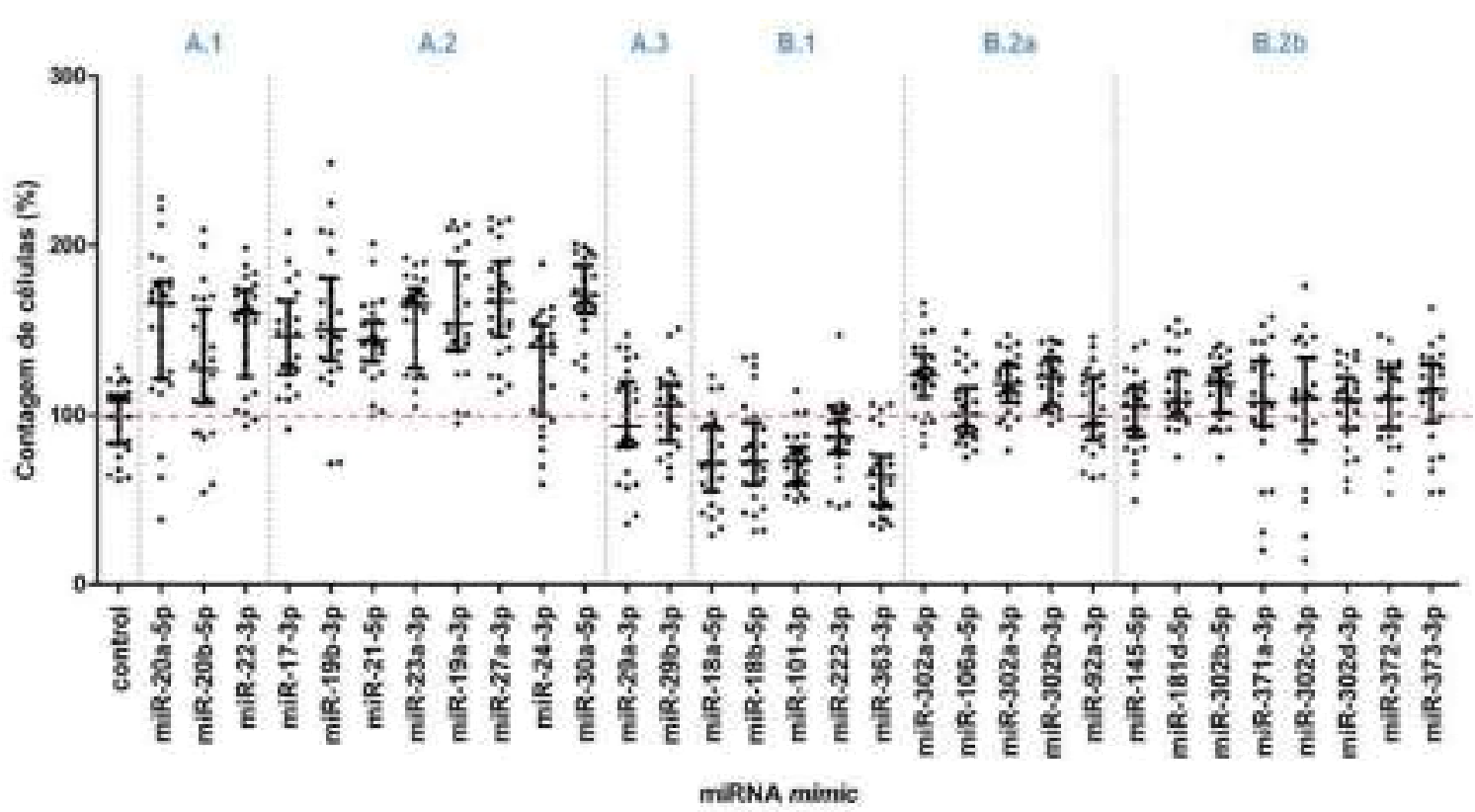

Figura 27. Gráfico de dispersão apresentando os resultados em porcentagem (relativos ao grupo controle negativo) de cada sítio (pontos pretos) das replicatas (poço) de tranfecção com os diferentes miR mimics na linhagem NTera-2. Aqui se encontram apresentados os efeitos destas moléculas sobre o número de células encontrado por sítio em cada replicata (poço), representado pela contagem de células mediana. A linha tracejada vermelha (na horizontal) representa a mediana do grupo controle, enquanto os clusters de miRNAs, gerados na clusterização fenotípica, se encontram separados pelas listas tracejadas azúis (na vertical).

\subsubsection{Alterações fenotípicas induzidas por miRNAs na linhagem H1}

Na Figura 28, destaca-se a formação de três grandes clusters de miRNAs como resultado da clusterização baseada nos fenótipos induzidos pelos miR mimics na linhagem de CTE humana, sendo estes nomeados de A, B e C. Assim como aconteceu na linhagem NTera2, variações dentro de alguns clusters também originaram subclusters, sendo estes B.1, B.2, C.1, C.2a, C.2b, C.2c. Ao se observar os efeitos dos miRNAs sobre a expressão de OCT4 e CCNB1, nota-se que os miRNAs de A e B.2 causaram importante redução na quantificação destes, tanto no núcleo como no citoplasma e essas mudanças são relacionadas com diferenciação celular. Já nos clusters B.1 e C, é observado um aumento nas intensidades de fluorescência destes marcadores, sugerindo uma atividade pró-pluripotência.

O cluster A, neste caso composto pelos miR-17-3p, miR-22-3p, miR-27a-3p e miR$30 \mathrm{a}-5 \mathrm{p}$, se caracterizou por um aumento na contagem de células e na área celular, além da diminuição na expressão dos marcadores de pluripotência e proliferação celular, sendo mais fortemente observada para o miR-30a-5p. O cluster B, por sua vez, foi agrupado pelas semelhanças nas quantificações morfométricas e de contagem de células. Tanto o subcluster B.1 quanto B.2 apresentou uma redução no número de células, com aumento na área do núcleo e citoplasma, e também na complexidade celular, porém diferiram quanto ao padrão de expressão de OCT4 e CCNB1. No subcluster B.1, constituído pelos miR-18a-5p, miR-18b- 
5p, miR-24-3p, miR-101-3p e miR-363-3p, é interessante observar que, embora os três primeiros miRNAs tenham demonstrado uma indução na quantificação de CCNB1 no núcleo e citoplasma, como também de OCT4 citoplasmático, eles levaram a uma diminuição na quantificação de OCT4 nuclear, o que poderia estar mais relacionado com perda da pluripotência nas células transfectadas com estes miRNAs. Já os miR-101-3p e miR-363-3p levaram a um aumento na quantificação de OCT4 no núcleo, embora não tenham causado um aumento de OCT4 citoplasmático, mantendo estes níveis próximos ao PMC. Por sua vez, o subcluster B.2 é constituído pelos miR-29a-3p e miR-29b-3p, os quais induziram alterações morfométricas e nas intensidades de OCT4 e CCNB1 claramente associadas à indução de diferenciação celular.

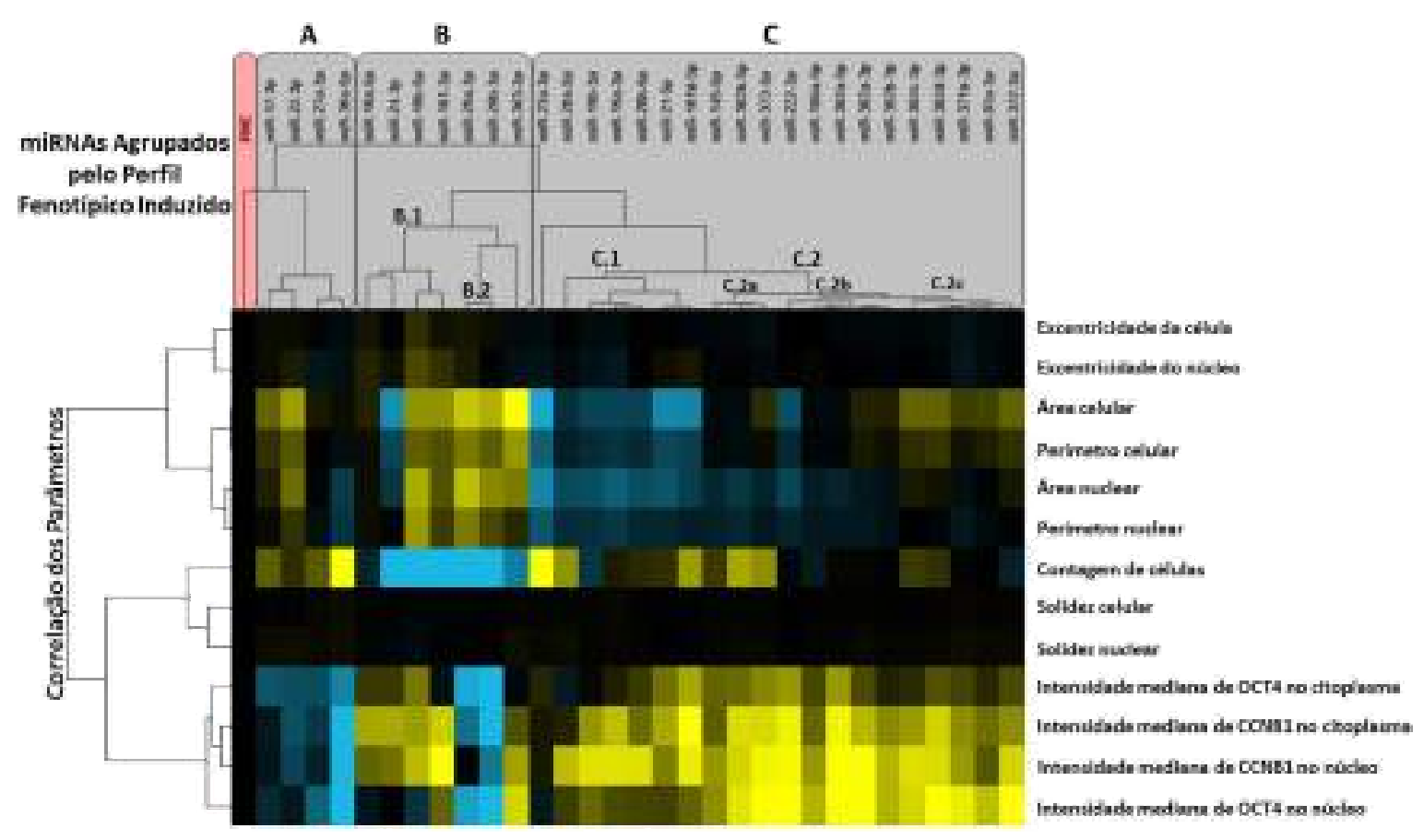

Figura 28. Clusterização dos miRNAs por seus efeitos fenotípicos sobre a linhagem H1, baseando-se nos dados quantitativos gerados da análise de imagens de fluorescência, por meio do CellProfiler, de células transfectadas com miR mimics e controle negativo (PMC). No heatmap, onde azul brilhante representa um menor valor, amarelo brilhante representa um maior e preto seria o valor central, são apresentas as medidas relativas dos traços fenotípicos selecionados, resultantes da normalização de cada tratamento pelo controle negativo com o uso de ferramentas do KNIME. De acordo com os perfis induzidos por cada miRNA, foram identificados três clusters principais, sendo os cluster A e B.2 formados por miRNAs que induziram diferenciação celular, e os clusters B.1 e C, por aqueles que promoveram características de pluripotência. Os subclusters identificados originaram-se, principalmente, pelas semelhanças e diferenças morfológicas observadas em cada tratamento.

Uma grande parte dos miRNAs aqui testados se agrupou no cluster $\mathrm{C}$, que se caracteriza principalmente pelo aumento nas quantificações de OCT4 e CCNB1, e contagem de células igual ou maior que do controle. No subcluster C.1 se encontram os miR-19a-3p, miR-19b-3p, miR-20a-5p, miR-20b-5p, miR-21-5p, miR-23a-3p e miR-181d-5p, que levaram a uma diminuição no tamanho das células, como também dos núcleos destas, e apresentaram 
um aumento moderado nas intensidades de OCT4 nuclear e citoplasmático, bem como na de CCNB1 no citoplasma. Ainda é interessante notar que as células transfectadas com o miR23a-3p apresentou uma quantificação de OCT4 nuclear menor que a do grupo PMC, aparecendo como um ramo externo deste cluster.

O subcluster C.2 compreende diversos miRNAs já relacionados com características de pluripotência, como todos os miR-302 aqui utilizados, e apresenta as maiores intensidades de OCT4 e CCNB1 tanto no citoplasma quanto no núcleo das células. Algumas diferenças relacionadas com a citomorfologia dos grupos transfectados com os miR mimics o dividiu nos subclusters C.2a, C.2b e C.2c. Em C.2a, onde se encontram os miR-145-5p, miR-302b-5p, miR-373-3p, as células apresentaram um tamanho ligeiramente maior que o grupo PMC, diferenciando-se do subcluster C.2b principalmente por apresentar uma maior contagem de células. Como dito, em C.2b a contagem celular foi bem próximas do grupo controle, sendo um pouco menor em alguns casos, e essas células apresentaram núcleos pequenos, variando quanto ao tamanho celular total. Os miRNAs agrupados neste subcluster são miR-106a-5p, miR-222-3p, miR-302a-3p, miR-302a-5p e miR-302b-3p. No caso de C.2c, os miR-92a-3p, miR-302c-3p, miR-302d-3p, miR-371-3p, miR-372-3p se agruparam por, principalmente, levarem ao aumento no tamanho celular e apresentarem contagem de células próxima ou maior que o grupo PMC.

Os resultados para cada um dos treze parâmetros fenotípicos analisados nas imagens das células da linhagem $\mathrm{H} 1$, transfectadas com os diferentes miR mimics, podem ser observados de forma individual nas Figuras 29 a 35 sendo que os dados apresentados são originados de cada um dos vinte e sete sítios imageados ( 9 por replicata) para cada grupo de tratamento. Os valores plotados nos gráficos são relativos ao grupo transfectado com PMC. 

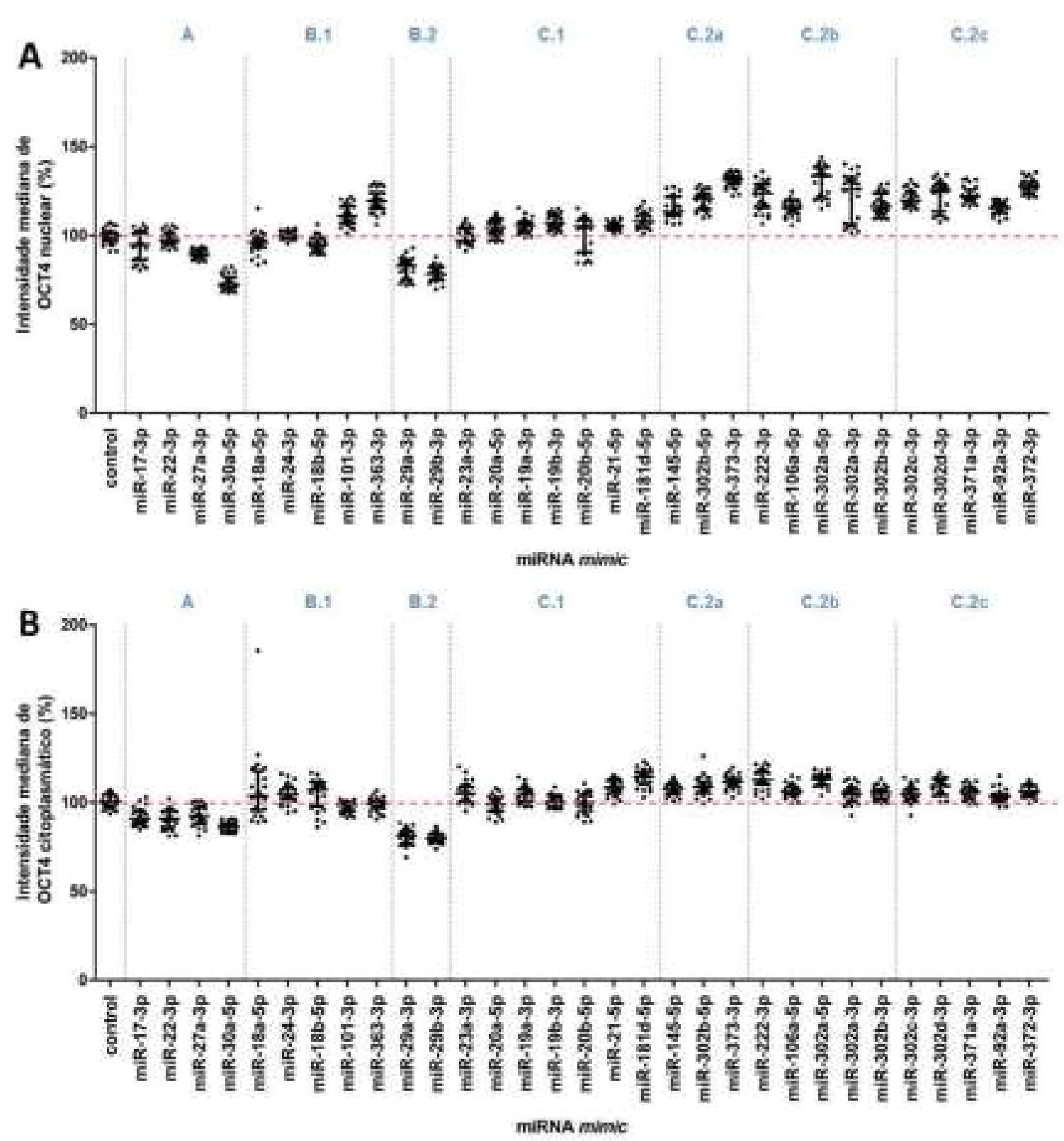

Figura 29. Gráficos de dispersão apresentando os resultados em porcentagem (relativos ao grupo controle negativo) de cada sítio (pontos pretos) das replicatas (poço) de tranfecção com os diferentes miR mimics na linhagem H1. Aqui se encontram apresentados os efeitos destas moléculas sobre as quantificações de OCT4 no núcleo e citoplasma, representadas pelas intensidades medianas de OCT4 nuclear (A) ou citoplasmática (B). A linha tracejada vermelha (na horizontal) representa a mediana do grupo controle, enquanto os clusters de miRNAs, gerados na clusterização fenotípica, se encontram separados pelas listas tracejadas azúis (na vertical). 

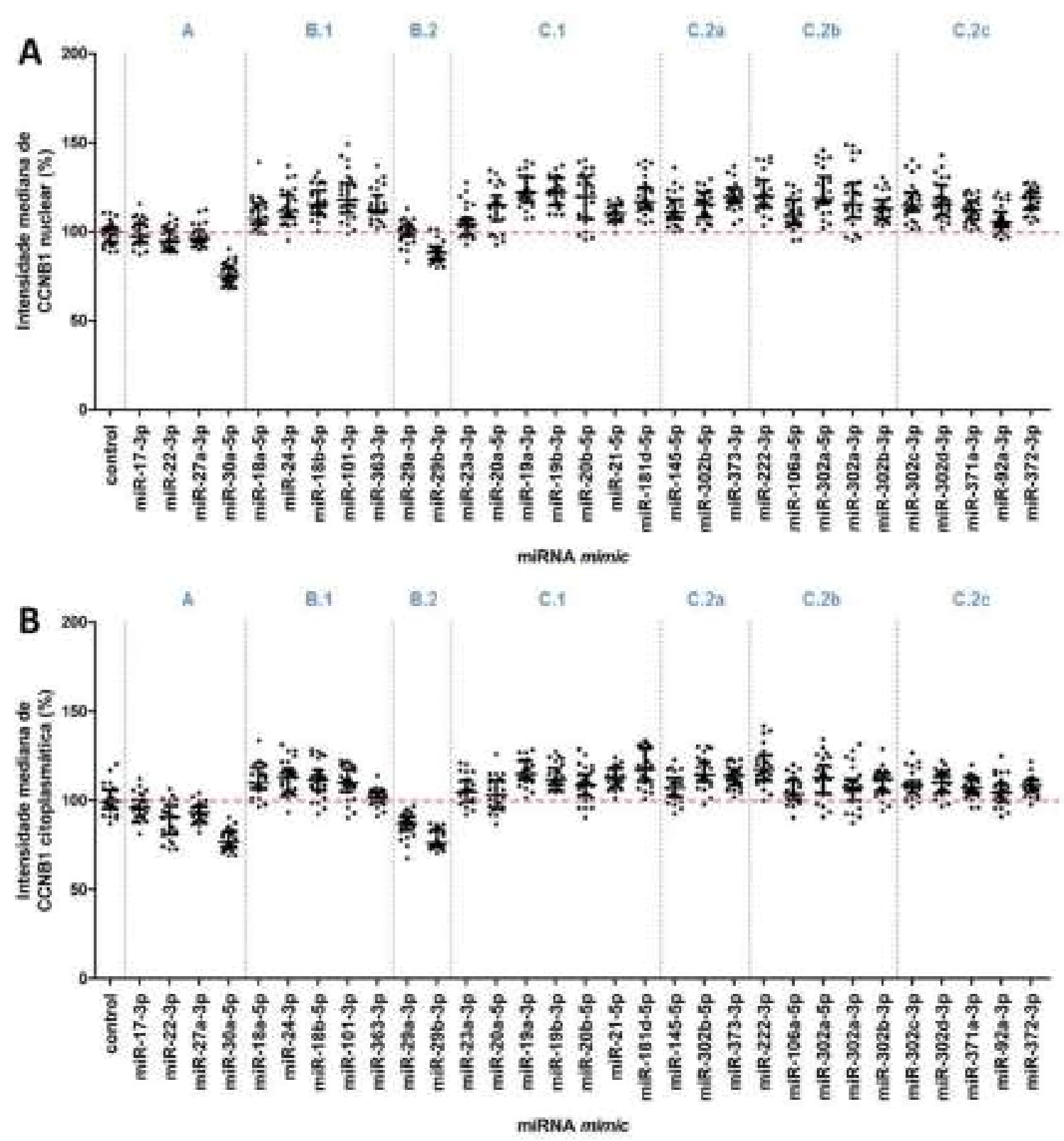

Figura 30. Gráficos de dispersão apresentando os resultados em porcentagem (relativos ao grupo controle negativo) de cada sítio (pontos pretos) das replicatas (poço) de tranfecção com os diferentes miR mimics na linhagem H1. Aqui se encontram apresentados os efeitos destas moléculas sobre as quantificações de CCNB1 no núcleo e citoplasma, representadas pelas intensidades medianas de CCNB1 nuclear (A) ou citoplasmática (B). A linha tracejada vermelha (na horizontal) representa a mediana do grupo controle, enquanto os clusters de miRNAs, gerados na clusterização fenotípica, se encontram separados pelas listas tracejadas azúis (na vertical). 


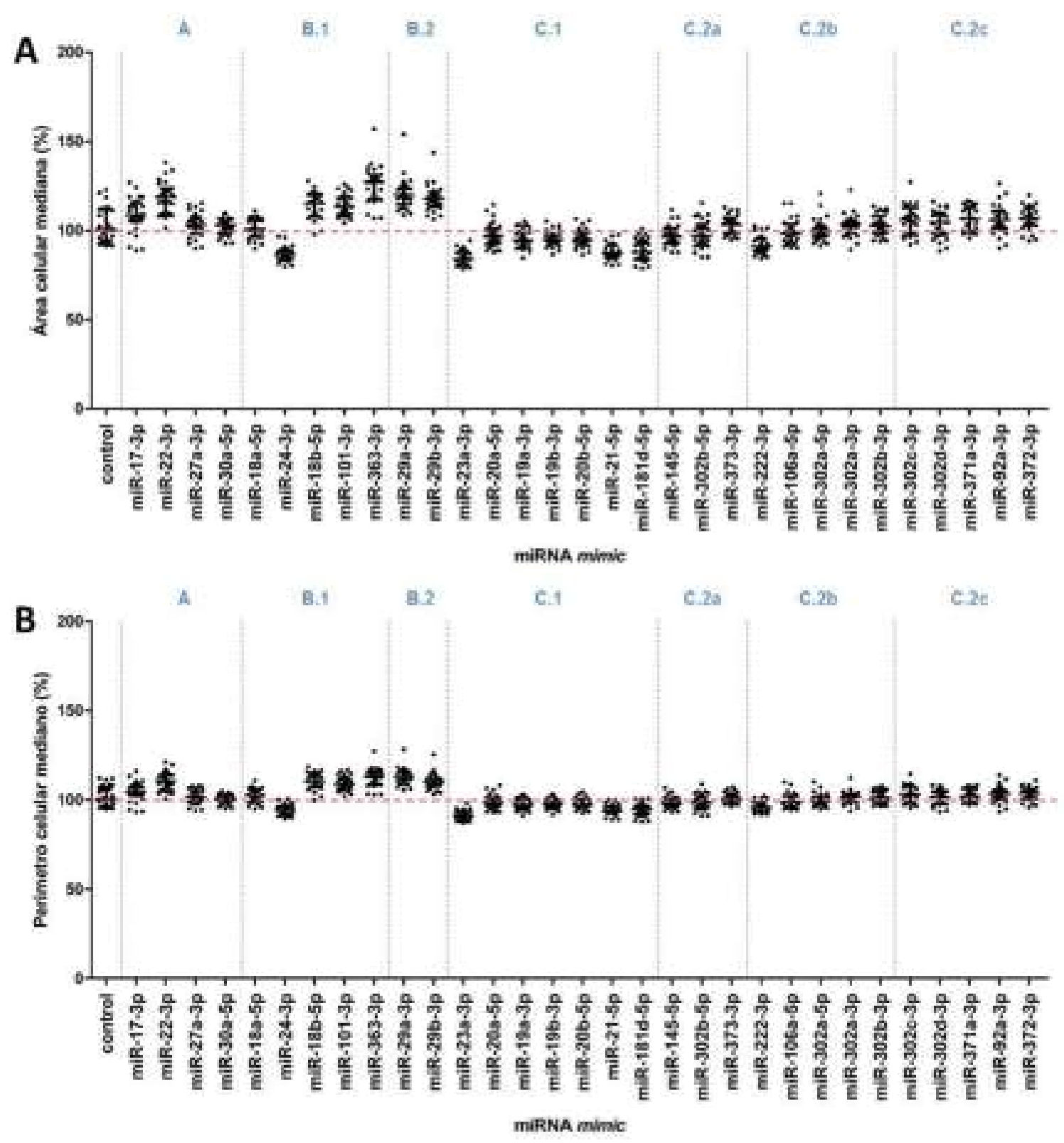

Figura 31. Gráficos de dispersão apresentando os resultados em porcentagem (relativos ao grupo controle negativo) de cada sítio (pontos pretos) das replicatas (poço) de tranfecção com os diferentes miR mimics na linhagem H1. Aqui se encontram apresentados os efeitos destas moléculas sobre o tamanho das células, representados pela área $(\mathbf{A})$ e perímetro (B) celulares medianos. A linha tracejada vermelha (na horizontal) representa a mediana do grupo controle, enquanto os clusters de miRNAs, gerados na clusterização fenotípica, se encontram separados pelas listas tracejadas azúis (na vertical). 


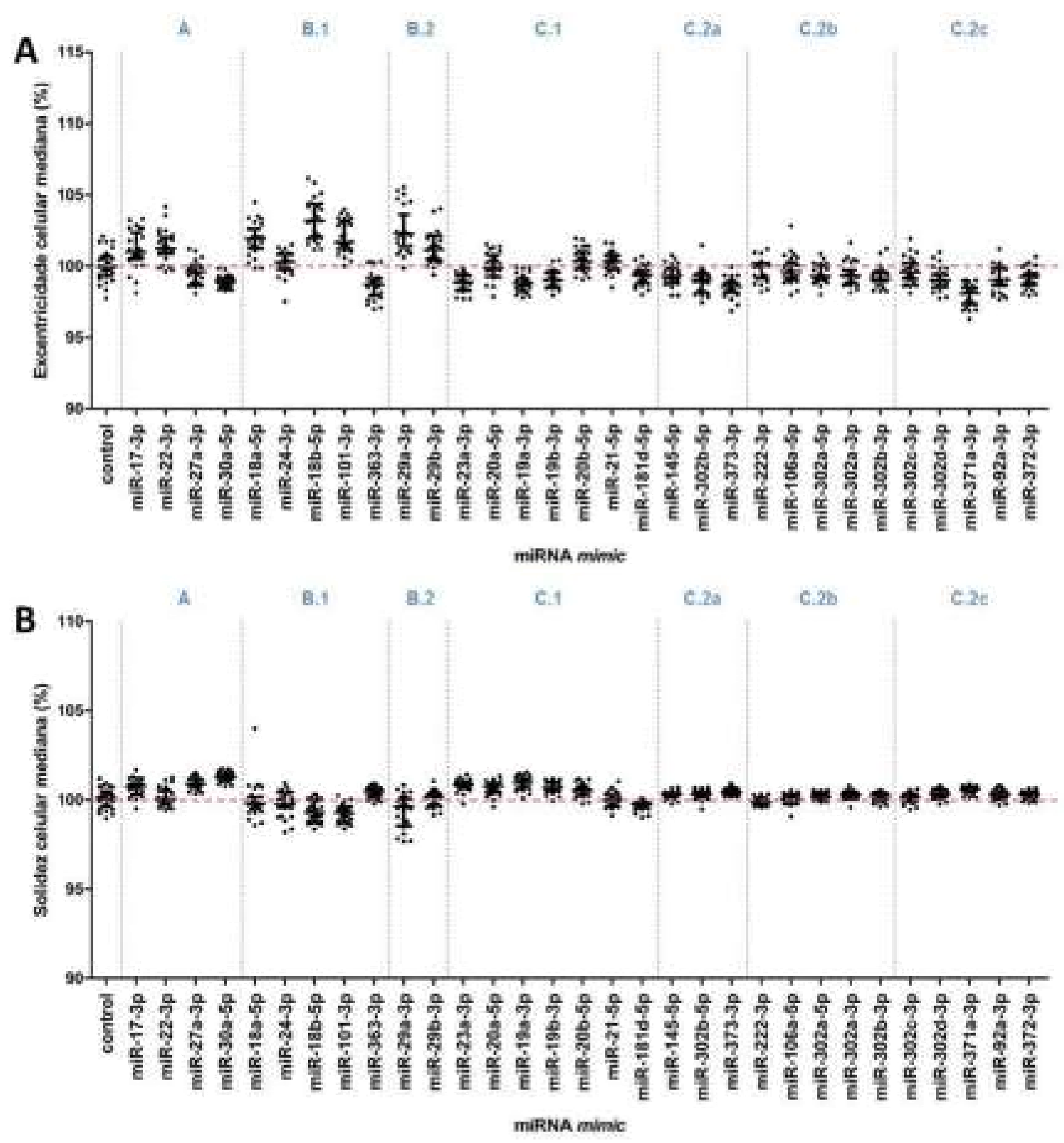

Figura 32. Gráficos de dispersão apresentando os resultados em porcentagem (relativos ao grupo controle negativo) de cada sítio (pontos pretos) das replicatas (poço) de tranfecção com os diferentes miR mimics na linhagem H1. Aqui se encontram apresentados os efeitos destas moléculas sobre a complexidade das células, representados pela quantificação da excentricidade celular (\%) (A) e solidez celular (\%) (B) medianas. A linha tracejada vermelha (na horizontal) representa a mediana do grupo controle, enquanto os clusters de miRNAs, gerados na clusterização fenotípica, se encontram separados pelas listas tracejadas azúis (na vertical). 

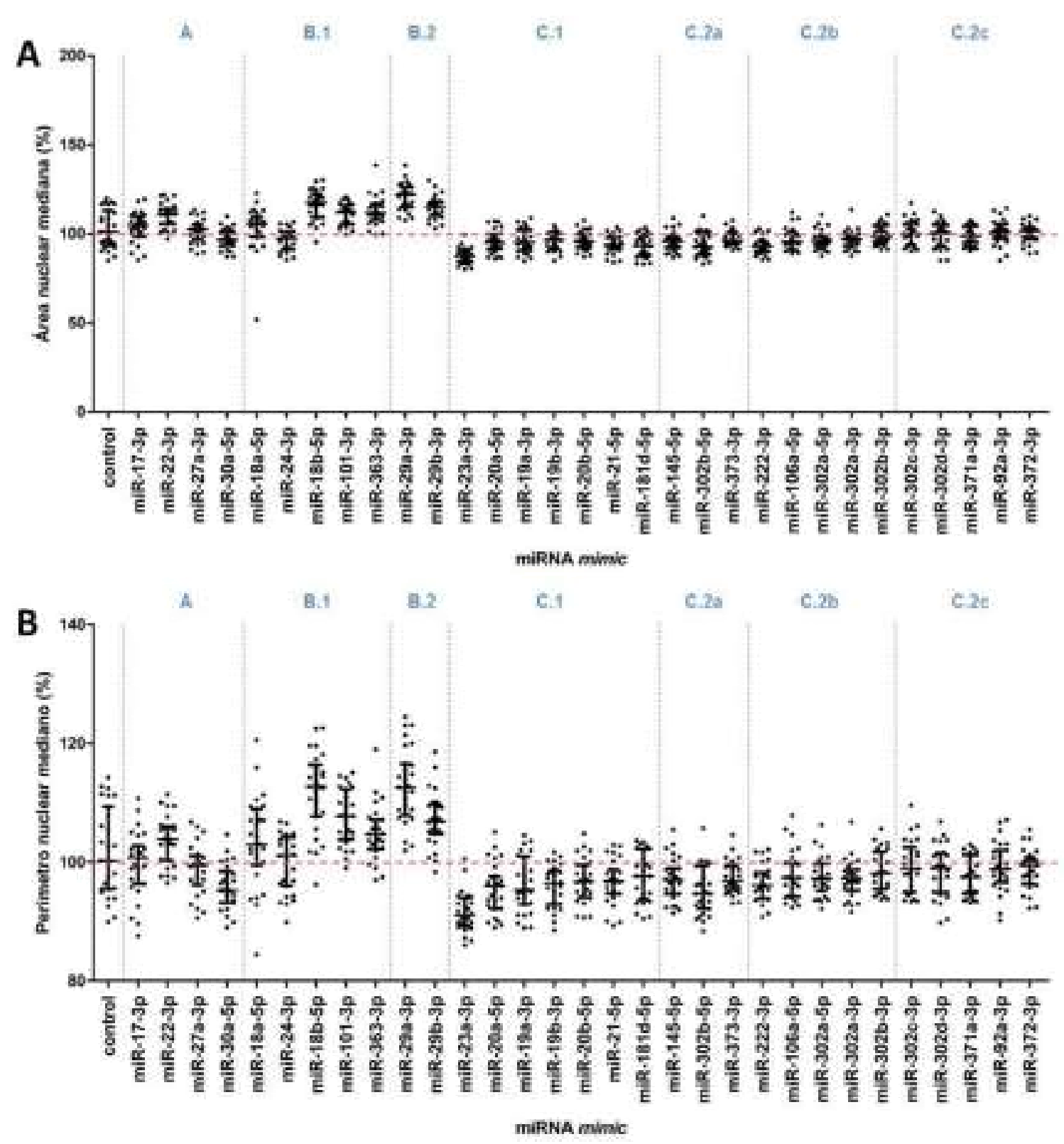

Figura 33. Gráficos de dispersão apresentando os resultados em porcentagem (relativos ao grupo controle negativo) de cada sítio (pontos pretos) das replicatas (poço) de tranfecção com os diferentes miR mimics na linhagem H1. Aqui se encontram apresentados os efeitos destas moléculas sobre o tamanho dos núcleos celulares, representados pela quantificação da área (A) e perímetro (B) nucleares medianos. A linha tracejada vermelha (na horizontal) representa a mediana do grupo controle, enquanto os clusters de miRNAs, gerados na clusterização fenotípica, se encontram separados pelas listas tracejadas azúis (na vertical). 

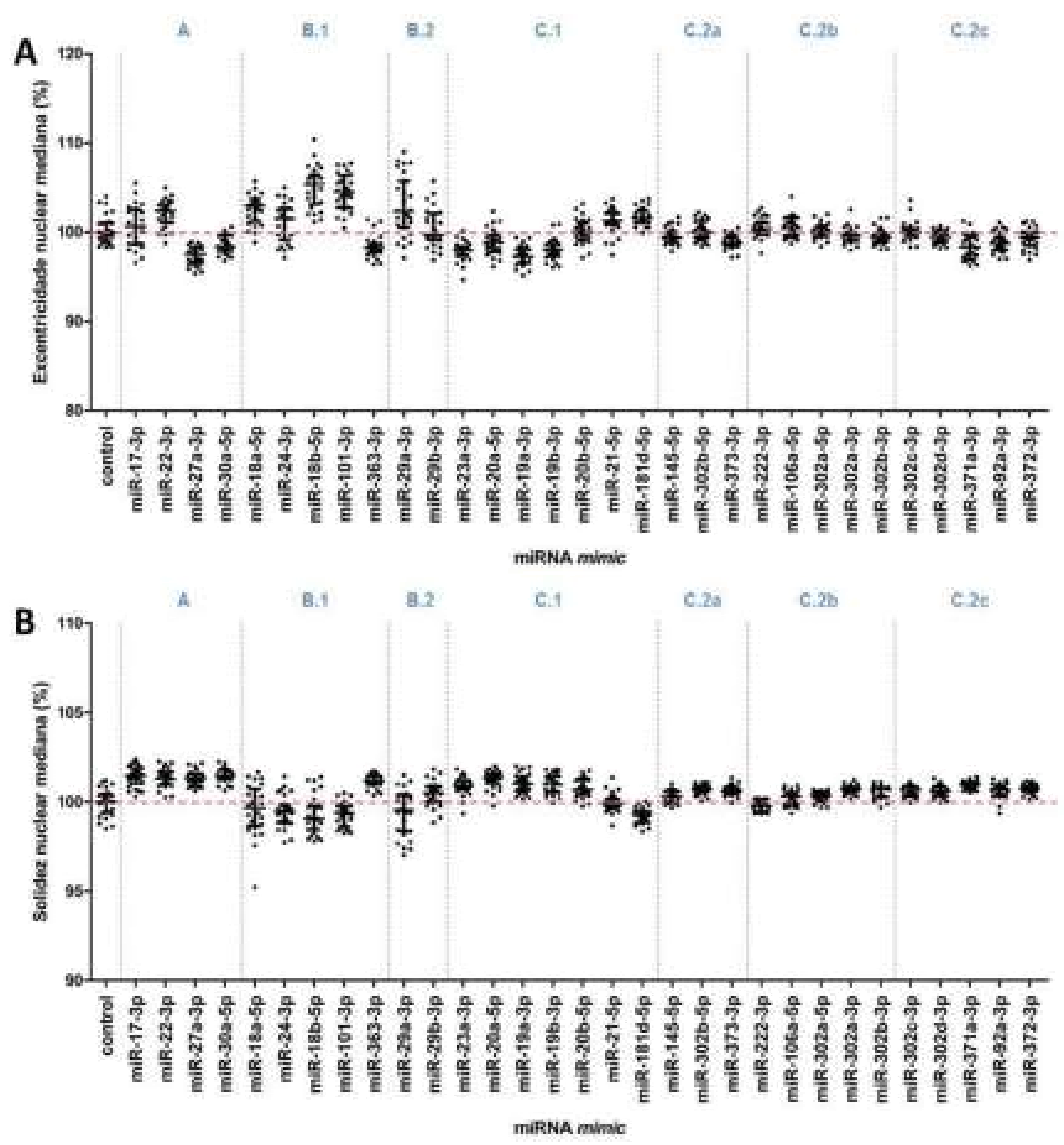

Figura 34. Gráficos de dispersão apresentando os resultados em porcentagem (relativos ao grupo controle negativo) de cada sítio (pontos pretos) das replicatas (poço) de tranfecção com os diferentes miR mimics na linhagem H1. Aqui se encontram apresentados os efeitos destas moléculas sobre a complexidade dos núcleos celulares, representados pela quantificação da excentricidade (A) e solidez (B) nucleares medianas. A linha tracejada vermelha (na horizontal) representa a mediana do grupo controle, enquanto os clusters de miRNAs, gerados na clusterização fenotípica, se encontram separados pelas listas tracejadas azúis (na vertical). 


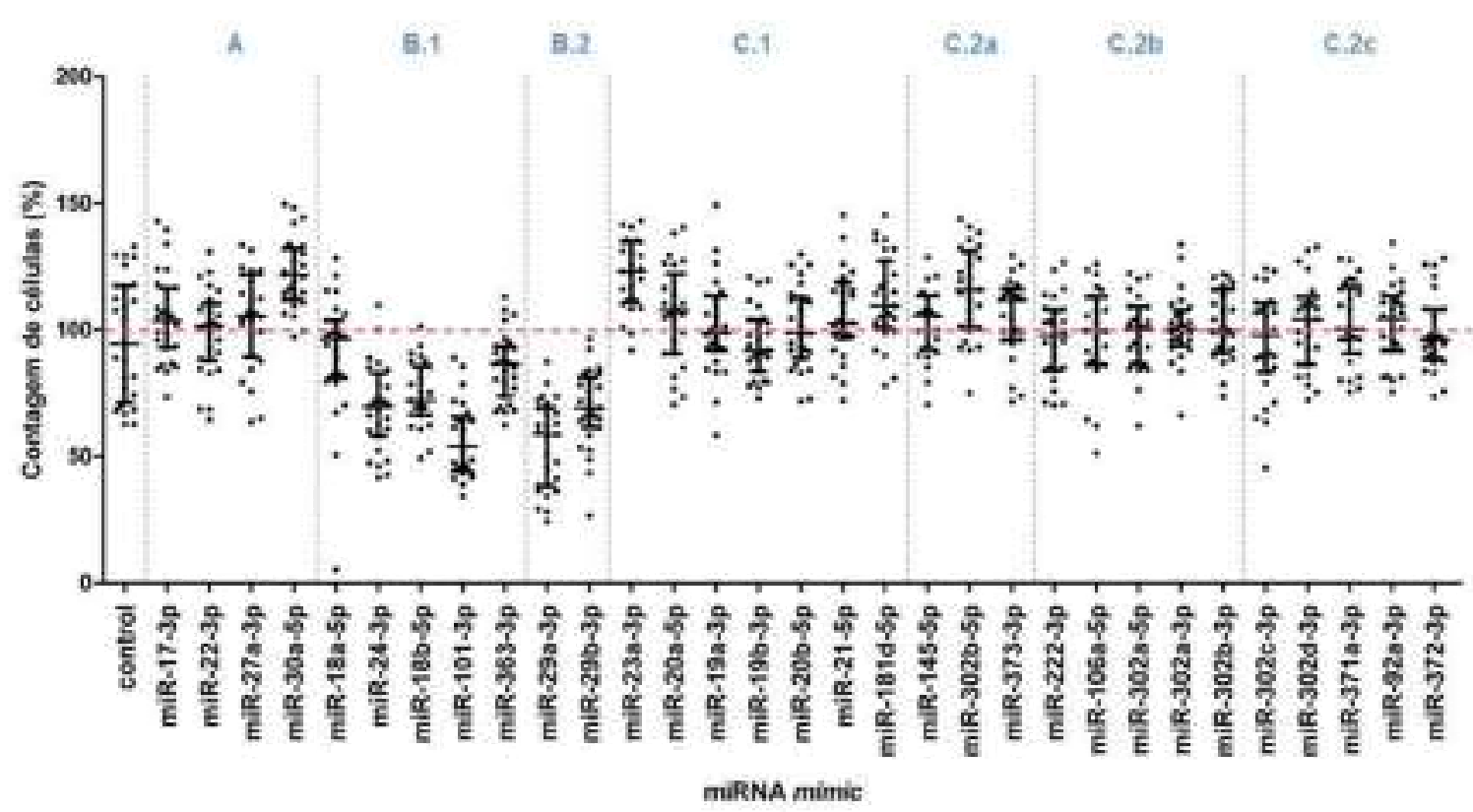

Figura 35. Gráfico de dispersão apresentando os resultados em porcentagem (relativos ao grupo controle negativo) de cada sítio (pontos pretos) das replicatas (poço) de tranfecção com os diferentes miR mimics na linhagem H1. Aqui se encontram apresentados os efeitos destas moléculas sobre o número de células encontrado por sítio em cada replicata (poço), representado pela contagem de células mediana. A linha tracejada vermelha (na horizontal) representa a mediana do grupo controle, enquanto os clusters de miRNAs, gerados na clusterização fenotípica, se encontram separados pelas listas tracejadas azúis (na vertical).

\subsection{Identificação de alvos e vias reguladas pelos miRNA dos diferentes clusters}

Uma vez bem definidos os clusters de miRNAs, de acordo com seus efeitos sobre a morfologia e expressão de OCT4 e CCNB1 nas linhagens pluripotentes aqui empregadas, foi realizada a identificação de alvos compartilhados entre os membros de cada cluster, seguida da identificação de vias de sinalização possivelmente reguladas por estes miRNAs, sendo os fenótipos observados nos clusters o resultado da modulação destas vias nas células pluripotentes. Nos subtópicos a seguir, são apresentados os achados para cada uma das linhagens de forma individual, com o intuito de permitir uma visualização mais simples dos resultados observados.

\subsubsection{Alvos e vias regulados pelos clusters de miRNAs na linhagem NTera-2}

De acordo com seus efeitos sobre a linhagem de CCE, os miRNAs aqui estudados foram divididos em dois grandes clusters, sendo os miRNAs com efeitos pró-diferenciação agrupados no cluster A e aqueles com atividades pró-pluripotência, no cluster B. No subcluster A.1, foram identificados cerca de 1760 mRNAs compartilhados entre os alvos destes miRNAs e, por meio da ferramenta DAVID para anotação funcional, foram encontradas no KEGG PATHWAY Database e BIOCARTA 79 vias potencialmente 
reguladas por estes miRNAs, das quais se destacam as seguintes vias: PI3K-AKT, MAPK, TNF, TGF $\beta$, WNT e vias de sinalização regulando a pluripotência em células-tronco (Figuras S01 a S06). Para o subcluster A.2, foram detectados 109 genes compartilhados e 8 vias, destacando-se as vias de regulação do citoesqueleto de actina e a via de sinalização mTOR (Figuras S07 e S08). Por sua vez, para o cluster A.3, devido ao fato de ser formado por duas variantes do miR-29, foram encontrados mais de 3500 genes compartilhados, sendo necessário a utilização de um filtro para poder aplicá-los na ferramenta DAVID. Para isso, foram selecionados somente os genes exclusivos deste cluster ao comparar o conjunto de genes de A.3 com os dos demais clusters identificados e, para isso, foi utilizada a ferramenta Venny 2.1 (http://bioinfogp.cnb.csic.es/tools/venny/). Por fim, um total de 2523 genes foi aplicado para a identificação de vias possivelmente reguladas pelos miRNas deste cluster, resultando na observação de 71 delas, dentre elas a via de recepetores de matriz extracelular, adesão focal, sinalização de IGF-1, mTOR, PI3K-AKT, TNF, WNT e vias de sinalização regulando a pluripotência em células-tronco (Figuras S09 a S16). Os alvos de cada subcluster de A identificados em cada uma das vias encontram-se descritos na Tabela 04.

Para o cluster B, foram identificados os alvos e vias possivelmente regulados em cada subcluster da mesma forma que para o cluster A. Sendo assim, no subcluster B.1 foram observados 338 genes compartilhados e 11 vias possivelmente reguladas, incluindo as vias de sinalização de FOXO e RAS (Figuras S17 e S18). Já para B.2a, a identificação de 896 genes compartilhados entre os alvos dos miRNAs resultou na observação de 20 vias possivelmente reguladas, dentre elas as vias de DICER, FOXO, mTOR, PI3K-AKT e de Toll-like receptor (Figuras S19 a S23). Por último, para o subcluster B.2b, os 153 genes alvos compartilhados entre os miRNAs levaram a identificação de 7 vias, sendo parte delas a via de DICER, VEGF e vias de sinalização regulando a pluripotência em células-tronco (Figuras S24 a S26). Na Tabela 05 podem ser encontrados os genes alvos dos miRNAs dos diferentes subclusters que se encontram em cada uma das vias destacadas. 
Tabela 4. Genes alvos de cada subcluster separados de acordo com a via biológica detectada pela ferramenta DAVID. No presente caso, encontram-se descritos os dados do cluster A na linhagem NTera-2.

\begin{tabular}{|c|c|c|}
\hline \multirow{6}{*}{ 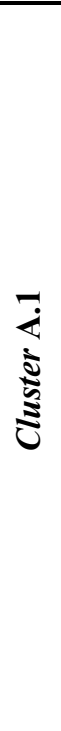 } & PI3K-AKT & $\begin{array}{l}\text { FGFR1, YWHAZ, PHLPP2, GRB2, FASLG, ITGA10, FGF12, PTEN, IGF1R, } \\
\text { EIF4EBP1, PDPK1, ITGB8, PPP2CA, ITGB6, PDGFC, AKT3, SYK, PPP2R1B, } \\
\text { PRKCA, COL4A4, CREB1, CREB5, ITGA3, IL6R, RPTOR, IFNAR1, PCK1, OSM, } \\
\text { MAPK1, NRAS, CDKN1A, HSP90B1, PRLR, IKBKG, MDM2, GNB4, LAMC1, } \\
\text { IKBKB }\end{array}$ \\
\hline & МАРК & $\begin{array}{l}\text { FGFR1, IL1R1, GRB2, MRAS, DUSP10, PPP3R1, MKNK2, MAP4K2, FASLG, } \\
\text { HSPA1B, FGF12, CACNB4, MAP3K7, MAP3K5, MAP3K3, MAP3K2, MAPT, FAS, } \\
\text { TRAF6, AKT3, RASA2, PRKCA, MAPK10, TAB1, STK4, PRKCB, RPS6KA,, } \\
\text { MAPK1, NRAS, DUSP3, RASGRF2, MAPK13, ARRB1, MAPK14, IKBKG, NTRK2, } \\
\text { CACNA1E, IKBKB, CACNA1D, MAP3K13, CRK, MAP3K12 }\end{array}$ \\
\hline & TNF & $\begin{array}{l}\text { TRAF1, CREB1, CREB5, MAPK10, CX3CL1, TAB1, MAP3K7, LIF, CASP10, } \\
\text { MAPK1, MAP3K5, TNFRSF1B, MAPK13, MAPK14, IKBKG, FAS, IKBKB, AKT3 }\end{array}$ \\
\hline & TGF及 & $\begin{array}{l}\text { PPP2R1B, BMP2, RBL1, SMAD5, BMPR2, SMAD4, ACVR1B, MAPK1, ACVR2B, } \\
\text { EP300, ZFYVE16, PPP2CA, ZFYVE9, SMURF1 }\end{array}$ \\
\hline & WNT & $\begin{array}{l}\text { CSNK1A1, PRKCA, WNT5A, FZD8, TCF7, ROCK2, SMAD4, PPP3R1, MAPK10, } \\
\text { FZD5, PRKCB, FZD6, WNT2B, MAP3K7, DKK2, EP300, PSEN1, SFRP2, } \\
\text { CAMK2D, WNT9B, NFATC4, SOX17, TBL1X, FOSL1 }\end{array}$ \\
\hline & $\begin{array}{l}\text { Vias Regulando a } \\
\text { Pluripotência }\end{array}$ & $\begin{array}{l}\text { WNT5A, FGFR1, IL6ST, GRB2, BMPR2, PAX6, REST, LIF, PCGF5, IGF1R, } \\
\text { ACVR1B, SKIL, AKT3, FZD8, BMP2, ESRRB, SMAD5, SMAD4, FZD5, WNT2B, } \\
\text { FZD6, NRAS, MAPK1, ACVR2B, RIF1, MAPK13, MAPK14, WNT9B, KAT6A }\end{array}$ \\
\hline \multirow{2}{*}{ 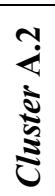 } & $\begin{array}{l}\text { Regulação do } \\
\text { Citoesqueleto de } \\
\text { Actina }\end{array}$ & MAPK1, ITGB8, ITGA1, ABI2 \\
\hline & mTOR & MAPK1, TSC1, RRAGD \\
\hline \multirow{8}{*}{ 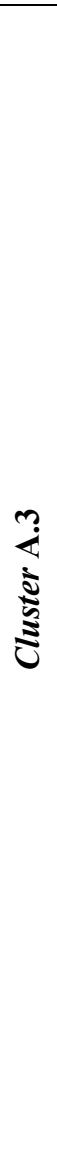 } & $\begin{array}{l}\text { Receptores de } \\
\quad \text { Matriz } \\
\text { Extracelular }\end{array}$ & $\begin{array}{l}\text { COL3A1, ITGA11, DAG1, COL2A1, ITGB1, COL6A6, GP1BB, COL27A1, } \\
\text { COL6A3, COL6A2, COL6A1, COL11A1, SV2C, COL4A3, COL4A2, COL4A1, } \\
\text { HSPG2, ITGA2, COL5A3, COL5A2, COL5A1, COL4A6, COL4A5, LAMA2, ITGA, } \\
\text { LAMC3, COL1A2, LAMC2, COL1A1, COL24A1 }\end{array}$ \\
\hline & Adesão Focal & $\begin{array}{l}\text { TLN1, PDGFB, TLN2, PDGFA, BCAR1, VCL, CDC42, ARHGAP5, PDGFD, SHC3, } \\
\text { COL11A1, AKT2, PIK3CG, PIK3CB, ACTN2, CRKL, RASGRF1, LAMC3, VEGFA, } \\
\text { COL1A2, PDGFRA, MAPK9, PDGFRB, LAMC2, MAPK8, COL1A1, COL24A,, } \\
\text { PARVA, CAV2, COL3A1, ITGA11, COL2A1, ITGB1, COL6A6, BCL2, COL27A1, } \\
\text { COL6A3, COL6A2, COL6A1, PIK3R5, PIK3R3, PIK3R1, COL4A3, COL4A2, } \\
\text { COL4A1, ITGA2, IGF1, COL5A3, BIRC3, BIRC2, COL5A2, COL4A6, COL5A1, } \\
\text { COL4A5, LAMA2, ITGA6, FYN, GSK3B, RAP1A }\end{array}$ \\
\hline & IGF-1 & PIK3CG, FOS, IGF1, MAPK8, IRS1, PIK3R1, RASA1 \\
\hline & mTOR & $\begin{array}{l}\text { PIK3CG, PIK3CB, STRADA, RPS6KB2, IGF1, RICTOR, IRS1, RRAGC, RPS6KA3, } \\
\text { RPS6KA1, ULK2, PIK3R5, PIK3R3, EIF4E2, PIK3R1, AKT2 }\end{array}$ \\
\hline & PI3K-AKT & $\begin{array}{l}\text { PDGFB, PDGFA, EFNA2, RPS6KB2, FOXO3, CCNE1, IL4R, GNG2, PDGFD, } \\
\text { GNG4, COL11A1, AKT2, PIK3CG, PPP2R1A, SGK1, PIK3CB, RELA, RXRA, IRS1, } \\
\text { CDK2, LAMC3, VEGFA, COL1A2, PDGFRA, PDGFRB, EFNA5, LAMC2, } \\
\text { COL1A1, COL24A1, FGFR3, MCL1, COL3A1, ITGA11, TCL1A, COL2A1, GNG12, } \\
\text { ITGB1, G6PC3, COL6A6, BCL2, COL27A1, COL6A3, GYS1, COL6A2, COL6A1, } \\
\text { PIK3R5, PIK3R3, PPP2R2C, PIK3R1, COL4A3, COL4A2, IL2RA, COL4A1, ITGA2, } \\
\text { IGF1, COL5A3, YWHAE, COL5A2, COL4A6, COL5A1, COL4A5, LAMA2, GH2, } \\
\text { YWHAG, ITGA6, GSK3B, EPOR, EIF4E2 }\end{array}$ \\
\hline & TNF & $\begin{array}{l}\text { PIK3CG, IL18R1, PIK3CB, RELA, MAP2K4, BIRC3, BIRC2, CXCL10, TNFRSF1A, } \\
\text { FOS, CASP3, CASP7, CASP8, MAPK9, PIK3R5, MAPK8, TNFAIP3, PIK3R3, } \\
\text { TRAF5, PIK3R1, AKT2, TRAF3 }\end{array}$ \\
\hline & WNT & $\begin{array}{l}\text { NKD1, PPARD, WNT5B, NKD2, CAMK2G, DAAM1, DAAM2, GPC4, FRAT2, } \\
\text { NFATC3, WNT8B, APC, DVL3, TBL1XR1, WNT10B, VANGL1, FZD3, SKP1, } \\
\text { FZD4, CTNNBIP1, FZD10, WNT7B, GSK3B, LRP6, MAPK9, MAPK8 }\end{array}$ \\
\hline & $\begin{array}{l}\text { Vias Regulando a } \\
\text { Pluripotência }\end{array}$ & $\begin{array}{l}\text { FGFR3, WNT5B, PCGF3, HAND1, PIK3R5, PIK3R3, PIK3R1, APC, AKT2, } \\
\text { WNT8B, PIK3CG, SETDB1, DVL3, WNT10B, JARID2, PIK3CB, LIFR, IGF1, } \\
\text { FZD3, ISL1, FZD4, STAT3, ACVR2A, WNT7B, FZD10, ID1, GSK3B, ID3, ZFHX3, } \\
\text { KLF4, BMPR1A }\end{array}$ \\
\hline
\end{tabular}


Tabela 5. Genes alvos de cada subcluster separados de acordo com a via biológica detectada pela ferramenta DAVID. No presente caso, encontram-se descritos os dados do cluster B na linhagem NTera-2.

\begin{tabular}{|c|c|c|}
\hline \multirow{2}{*}{ 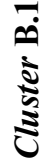 } & FOXO & CDKN2B, PIK3CA, BNIP3, SMAD2, AKT3, ATM \\
\hline & RAS & RASAL2, KSR2, GRIN2B, GAB1, PIK3CA, RAPGEF5, KIT, AKT3 \\
\hline \multirow{5}{*}{ 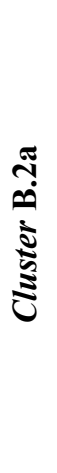 } & DICER & $\mathrm{AGO} 2, \mathrm{AGO} 3, \mathrm{AGO} 4$ \\
\hline & FOXO & $\begin{array}{l}\text { EGFR, G6PC, ATG12, SGK3, CCND2, PRKAB2, SETD7, PIK3CA, PRKAA2, } \\
\text { C8ORF44-SGK3, PTEN, BCL2L11 }\end{array}$ \\
\hline & mTOR & EIF4E, ULK1, PIK3CA, PRKAA2, RRAGD, PTEN, PRKCB \\
\hline & PI3K-AKT & $\begin{array}{l}\text { EGFR, YWHAZ, SGK3, CREB1, GNG11, TLR4, CDK6, C8ORF44-SGK3, PTEN, } \\
\text { BCL2L11, IFNAR2, G6PC, EIF4E, CHRM2, CCND2, TNR, ITGB6, PIK3CA, } \\
\text { PIK3AP1, PRKAA2, FGF2 }\end{array}$ \\
\hline & Toll-like Receptor & TIRAP, ELK1, TLR4, EIF2AK2, TRAF6, MAP2K6 \\
\hline \multirow{3}{*}{ 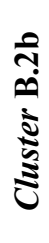 } & DICER & AGO2, AGO3 \\
\hline & VEGF & MAPK1, MAPK14, NFATC2 \\
\hline & $\begin{array}{l}\text { Vias Regulando a } \\
\text { Pluripotência }\end{array}$ & MAPK1, ACVR2B, MAPK14, ACVR1C \\
\hline
\end{tabular}




\subsubsection{Alvos e vias regulados pelos clusters de miRNAs na linhagem H1}

Como descrito anteriormente, na linhagem celular derivada de CTE humanas, a transfecção com os miR mimics dos miRNAs selecionados para o presente estudo levou a identificação de três clusters, baseando-se na semelhança entre os fenótipos resultantes dos tratamentos. Para o cluster A, onde 455 genes compartilhados entre os alvos dos miRNAs componentes deste cluster, foram identificadas 14 vias potencialmente reguladas, nas quais se incluem a via de sinalização RAS, de regulação do citoesqueleto de actina e vias de sinalização regulando a pluripotência em células-tronco (Figuras S27 a S29). Para o cluster B, em B.1 foram encontrados 397 genes alvos do subcluster e 14 vias, compreendendo a via de RAP1, mTOR e vias de sinalização regulando a pluripotência em células-tronco (Figuras S30 a S32); já para B.2, contendo somente as duas variantes do miR-29 tal qual o subcluster A.3 da linhagem NTera-2, foi realizada a mesma abordagem para filtrar os alvos exclusivo destes miRNAs em comparação com os demais clusters, resultando num grupo de 2573 genes alvos e identificação 81 vias possivelmente reguladas, das quais podem ser destacadas a via de recepetores de matriz extracelular, adesão focal, PI3K-AKT, TNF e vias de sinalização regulando a pluripotência em células-tronco (Figuras S33 a S37). A Tabela 06 contém as informações de cada um dos genes alvos dos miRNAs por cluster dentro das vias biológicas encontradas utilizando-se a ferramente DAVID.

Para os subclusters de C, as análises in silico detectaram em C.1 340 genes entre os alvos compartilhados, que levou a identificação de 29 vias que podem ser reguladas pelos miRNAS deste subcluster, incluindo a via de DICER, FOXO, mTOR e vias de sinalização regulando a pluripotência em células-tronco (Figuras S38 a S41). Em C.2a, os mais de 1150 genes alvos levaram a detecção de 48 vias possivelmente reguladas, tais como: via de FOXO, MAPK, mTOR, TGF $\beta$, Toll-like receptor e vias de sinalização regulando a pluripotência em células-tronco (Figuras S42 a S47). Para C.2b, foram encontrados 791 genes alvos compartilhados, que resultaram na identificação de 59 vias, das quais destacam-se aqui a via de DICER, EGF, FOXO, JAK-STAT, MAPK, mTOR, PI3K-AKT, RAS e vias de sinalização regulando pluripotência em células-tronco (Figuras S48 a S56). Por último, a análise dos alvos compartilhados entre os miRNAs do subcluster C.2c identificou 277 genes, os quais quando aplicados na ferramenta DAVID levaram a identificação de 19 vias potencialmente reguladas por estes miRNAs, dentre elas a via de DICER e de FOXO (Figuras S57 e 58). Todas as vias descritas como alvos de cada subcluster de C, bem como os alvos identificados nessas análises, encontram-se apresentados na Tabela 07. 
Tabela 6. Aqui se encontram apresentados os genes alvos de cada subcluster separados de acordo com a via biológica detectada pela ferramenta DAVID. No presente caso, encontram-se descritos os dados dos clusters A e B na linhagem H1.

\begin{tabular}{|c|c|c|}
\hline \multirow{3}{*}{$\frac{1}{\vdots}$} & RAS & $\begin{array}{l}\text { MAPK1, PLA2G16, KSR2, GRIN2B, PIK3CD, GRIN2A, PLA2G2C, ABL1, KSR1, } \\
\text { ABL2 }\end{array}$ \\
\hline & $\begin{array}{l}\text { Regulação do } \\
\text { Citoesqueleto de } \\
\text { Actina }\end{array}$ & $\begin{array}{l}\text { MAPK1, CHRM3, ITGB8, ITGA5, PPP1R12B, PIK3CD, ABI2, ARHGEF12, } \\
\text { PIP4K2B }\end{array}$ \\
\hline & $\begin{array}{l}\text { Vias Regulando } \\
\text { a Pluripotência }\end{array}$ & MAPK1, ACVR2B, IL6ST, PIK3CD, BMPR2, SMAD4, WNT2B \\
\hline \multirow{3}{*}{ 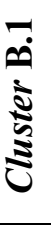 } & RAP1 & PARD6B, MAGI3, GRIN2B, MAPK13, RAP1A, PIK3CA, IGF1, CDH1 \\
\hline & mTOR & EIF4E, PIK3CA, IGF1, PRKAA1, RRAGD \\
\hline & $\begin{array}{l}\text { Vias Regulando } \\
\text { a Pluripotência }\end{array}$ & ONECUT1, MAPK13, GSK3B, BMPR2, PIK3CA, IGF1, SMAD2, FZD4 \\
\hline \multirow{5}{*}{ 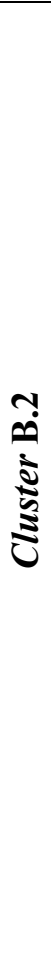 } & $\begin{array}{l}\text { Receptores de } \\
\text { Matriz } \\
\text { Extracelular }\end{array}$ & $\begin{array}{l}\text { COL3A1, ITGA11, DAG1, COL2A1, ITGB1, COL6A6, GP1BB, COL27A1, } \\
\text { COL6A3, COL6A2, COL6A1, COL11A1, THBS2, SV2C, COL4A3, COL4A2, } \\
\text { COL4A1, HSPG2, COL5A3, COL5A2, COL5A1, COL4A6, COL4A5, LAMA2, } \\
\text { ITGA6, LAMC3, COL1A2, LAMC2, COL1A1, LAMC1, COL24A1 }\end{array}$ \\
\hline & Adesão Focal & $\begin{array}{l}\text { TLN1, PDGFB, PDGFA, BCAR1, VCL, CDC42, ARHGAP5, PDGFC, PDGFD, } \\
\text { SHC3, RAPGEF1, COL11A1, AKT2, PIK3CG, PIK3CB, ACTN2, CRKL, RASGRF1, } \\
\text { LAMC3, VEGFA, COL1A2, PDGFRA, MAPK9, PDGFRB, LAMC2, MAPK8, } \\
\text { COL1A1, LAMC1, COL24A1, COL3A1, ITGA11, COL2A1, ITGB1, COL6A6, } \\
\text { BCL2, COL27A1, COL6A3, COL6A2, COL6A1, PIK3R5, PIK3R3, THBS2, PIK3R1, } \\
\text { COL4A3, COL4A2, COL4A1, COL5A3, BIRC3, COL5A2, BIRC2, COL4A,, } \\
\text { COL5A1, COL4A5, LAMA2, ITGA6, FYN }\end{array}$ \\
\hline & PI3K-AKT & $\begin{array}{l}\text { PDGFB, PDGFA, EFNA2, RPS6KB2, CCNE1, IL4R, PDGFC, GNG2, PDGFD, } \\
\text { GNG4, COL11A1, AKT2, PIK3CG, PPP2R1A, SGK1, PIK3CB, RELA, RXRA, IRS1, } \\
\text { CDK2, LAMC3, VEGFA, COL1A2, PDGFRA, MDM2, PDGFR, EFNA5, LAMC2, } \\
\text { LAMC1, COL1A1, COL24A1, FGFR1, FGFR3, PHLPP2, MCL1, COL3A1, ITGA1, } \\
\text { TCL1A, COL2A1, GNG12, ITGB1, G6PC3, COL6A6, PPP2CA, BCL2, COL27A1, } \\
\text { COL6A3, COL6A2, GYS1, COL6A1, PIK3R5, PIK3R3, PPP2R2C, THBS2, PIK3R1, } \\
\text { COL4A3, COL4A2, COL4A1, IL2RA, COL5A3, YWHAE, COL5A2, COL4A,, } \\
\text { COL5A1, COL4A5, LAMA2, GH2, NRAS, YWHAG, ITGA6, IKBKG, EPOR, } \\
\text { EIF4E2 }\end{array}$ \\
\hline & TNF & $\begin{array}{l}\text { PIK3CG, IL18R1, PIK3CB, RELA, MAP2K4, CX3CL1, BIRC3, TAB1, BIRC2, } \\
\text { CXCL10, LIF, TNFRSF1A, FOS, CASP3, CASP7, CASP8, IKBKG, MAPK9, } \\
\text { PIK3R5, MAPK8, TNFAIP3, PIK3R3, TRAF5, PIK3R1, AKT2 }\end{array}$ \\
\hline & $\begin{array}{l}\text { Vias Regulando } \\
\text { a Pluripotência }\end{array}$ & $\begin{array}{l}\text { FGFR1, FGFR3, WNT5B, LIF, PCGF3, HAND1, PIK3R5, PIK3R3, PIK3R1, APC, } \\
\text { AKT2, SETDB1, PIK3CG, DVL3, WNT10B, JARID2, PIK3CB, ISL1, NRAS, } \\
\text { ACVR2A, WNT7B, FZD10, ID1, ID3, ZFHX3, KLF4 }\end{array}$ \\
\hline
\end{tabular}


Tabela 7. Aqui se encontram apresentados os genes alvos de cada subcluster separados de acordo com a via biológica detectada pela ferramenta DAVID. No presente caso, encontram-se descritos os dados do cluster $\mathrm{C}$ na linhagem $\mathrm{H} 1$.

\begin{tabular}{|c|c|c|}
\hline \multirow{4}{*}{$\begin{array}{l}\vec{U} \\
\bar{\Xi} \\
\frac{5}{0}\end{array}$} & DICER & DICER1, AGO2, AGO4 \\
\hline & FOXO & MAPK1, TGFBR2, PRKAA2, MAPK10, PTEN, STK4, SOD2 \\
\hline & mTOR & MAPK1, PRKAA2, RRAGD, PTEN \\
\hline & $\begin{array}{l}\text { Vias Regulando a } \\
\text { Pluripotência }\end{array}$ & MAPK1, INHBA, IL6ST, GSK3B, BMPR2, LIFR, REST, WNT2B \\
\hline \multirow{6}{*}{ 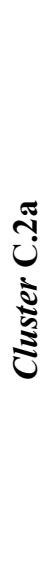 } & FOXO & $\begin{array}{l}\text { ATG12, TGFBR2, PRKAB2, SMAD3, SMAD2, IL7R, PTEN, SOD2, IGF1R, } \\
\text { MAPK1, G6PC, CSNK1E, CCND2, MAPK14, PIK3CA, SETD7, AKT3 }\end{array}$ \\
\hline & МАРК & $\begin{array}{l}\text { MEF2C, CACNA2D1, LAMTOR3, CACNG8, TAOK1, MAPKAPK5, TGFBR2, } \\
\text { MAP4K2, FGF10, ELK1, PRKCB, MAPK1, RPS6KA3, MAP3K2, ELK4, MAPK14, } \\
\text { FAS, PRKACB, RAPGEF2, TRAF6, MAP2K6, AKT3 }\end{array}$ \\
\hline & mTOR & MAPK1, RPS6KA3, EIF4E, ULK1, ULK3, PIK3CA, RRAGD, PTEN, AKT3, PRKCB \\
\hline & TGF及 & $\begin{array}{l}\text { INHBB, MAPK1, ACVR2B, GDF6, SMAD5, TGFBR2, RBL1, SMAD3, SMAD2, } \\
\text { THBS1, ACVR1C }\end{array}$ \\
\hline & Toll-like receptor & PPARA, MAPK14, TIRAP, ELK1, TLR4, EIF2AK2, TRAF6, MAP2K6 \\
\hline & $\begin{array}{l}\text { Vias Regulando a } \\
\text { Pluripotência }\end{array}$ & $\begin{array}{l}\text { ONECUT1, SMAD5, SMAD3, FZD3, SMAD2, REST, FZD5, FZD6, ACVR1C, } \\
\text { INHBB, IGF1R, MAPK1, ACVR2B, RIF1, MAPK14, PIK3CA, AKT3, WNT8B }\end{array}$ \\
\hline \multirow{9}{*}{ 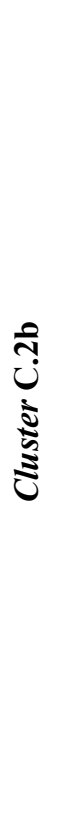 } & DICER & AGO1, AGO2, AGO3, AGO4 \\
\hline & EGF & EGFR, GRB2, PIK3CA, STAT3, PRKCB \\
\hline & FOXO & $\begin{array}{l}\text { EGFR, ATG12, GRB2, TGFBR2, PRKAB2, BCL2L11, STAT3, ATM, SOD2, } \\
\text { MAPK1, G6PC, CCND2, MAPK14, SETD7, PIK3CA, PRKAA2, AKT3 }\end{array}$ \\
\hline & JAK-STAT & IFNAR2, CCND2, GRB2, IFNE, PIK3CA, SOCS7, IL6R, SOCS5, AKT3, STAT3 \\
\hline & МАРК & $\begin{array}{l}\text { EGFR, GRB2, CACNG8, TAOK1, TGFBR2, PPP3R1, PRKCB, MAPK1, DUSP3, } \\
\text { MAP3K2, ELK4, MAPK14, CACNA1E, RAPGEF2, FGF2, MAP2K6, AKT3 }\end{array}$ \\
\hline & mTOR & MAPK1, EIF4E, PIK3CA, PRKAA2, AKT3, PRKCB \\
\hline & PI3K-AKT & $\begin{array}{l}\text { COL4A4, EGFR, GRB2, CREB1, LPAR3, GNG11, CDK6, IL6R, BCL2L11, IFNAR2, } \\
\text { MAPK1, G6PC, EIF4E, CHRM2, CCND2, PIK3CA, GNB4, PRKAA2, FGF2, AKT3, } \\
\text { SYK }\end{array}$ \\
\hline & RAS & $\begin{array}{l}\text { EGFR, PLA2G16, GRB2, GNG11, RGL1, PRKCB, RASAL2, MAPK1, PLCE1, } \\
\text { GRIN2B, PAK3, TIAM1, PLA2G12A, GAB1, RAPGEF5, PIK3CA, GNB4, FGF2, } \\
\text { AKT3 }\end{array}$ \\
\hline & $\begin{array}{l}\text { Vias Regulando a } \\
\text { Pluripotência }\end{array}$ & MAPK1, ACVR2B, RIF1, GRB2, MAPK14, SMAD5, PIK3CA, FGF2, AKT3, STAT3 \\
\hline \multirow{2}{*}{ 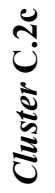 } & DICER & $\mathrm{AGO} 2, \mathrm{AGO} 3$ \\
\hline & FOXO & ATG12, SGK3, PIK3CA, FOXO3, C8ORF44-SGK3 \\
\hline
\end{tabular}




\subsubsection{Validação da ação reguladora dos miRNAs por qPCR}

Para que fosse avaliado o possível efeito dos miRNAs sobre o nível de transcritos de seus alvos, foram escolhidos miRNAs representantes de cada cluster identificado pelos perfís fenotípicos encontrados, tanto da linhagem NTera-2 como da linhagem H1. As moléculas de miR mimics destes representantes foram então transfectadas num dos modelos de pluripotência aqui estudados, a linhagem de CCE, e o RNA total foi extraído num período curto para que pudesse ser estudado o efeito direto do miRNA sobre o alvo e não uma possível atividade indireta e secundária, downstream à interação miRNA-mRNA alvo. No total, foram avaliados 22 genes, sendo que a grande maioria destes é encontrada como alvo nos clusters com constituição similar em ambas as linhagens pluripotentes.

Para os subclusters A.3 e B.2, repectivamente em NTera-2 e H1, foram avaliados os efeitos do miR-29b-3p sobre os transcritos de STAT3, RELA, LIF, KLF4, IL2RA, FGFRl, $I G F 1 R, A P C, T G F B 3$ e $C D K N 2 B$ e os resultados obtidos podem ser vistos na Figura 36. Para muitos destes genes, foi observada uma diminuição na quantificação dos níveis de transcritos, sendo esta estatisticamente significativa $(\mathrm{P}<0,05)$ para $K L F 4$ e $A P C$. Para $C D K N 2 B$ foi observado, de forma inesperada, um aumento estatisticamente significativo $(\mathrm{P}<0,05)$ na quantificação de seus transcritos.

$\mathrm{Na}$ Figura 37, estão apresentados os resultados obtidos para os demais miRs representantes dos clusters fenotípicos de NTera-2 e H1, sendo eles: miR-18b-5p (B.1/B.1), miR-20a-5p (A1/C1), miR-23a-3p (A.2/C1), miR-24-3p (A.2/B.1), miR-30a-5p (A.2/A), miR-92a-3p (B.2a/C.2c), miR-181d-5p (B.2b/C.1), miR-222-3p (B.1/C.2b), miR-302a-3p (B.2a/C.2b), miR-363-3p (B.1/B.1), miR-371a-3p (B.2b/C.2c), miR-373-3p (B.2b/C.2a).

Para $G S K 3 B$, os miR-24-3p e miR-363-3p causaram uma redução na quantificação de transcritos, sendo esta redução estatisticamente significativa $(\mathrm{P}<0,05)$ somente para $\mathrm{o}$ primeiro miRNA citado, enquanto o miR-18b-5p levou a um aumento estatisticamente significativo nesta quantificação. Para $S M A D 2$, somente o miR-18b-5p causou uma redução estatisticamente significativa $(\mathrm{P}<0,05)$ no nível transcricional, apesar de também ser observado um efeito causado pelos miR-24-3p e 373-3p. Com relação aos níveis de TGFBR2, os miR-20a-5p, miR-222-3p e miR-373-3p causaram uma diminuição $(\mathrm{P}<0,05)$ nas quantificações por qPCR. Também foram observadas reduções na quantificação de MAPK1 pelos miR-30a-5p, miR-181d-5p e miR-373-3p, de TCF3 pelo miR-24-3p, de PTEN pelo miR-181d-5p, e de FGF2 pelo miR-20a-5p, sendo todas essas reduções estatisticamente 
significativas $(\mathrm{P}<0,05)$. Para os genes CDK6, BMPR2 e IL6ST não foram detectadas alterações causadas pelos tratamentos com os miR mimics testados.
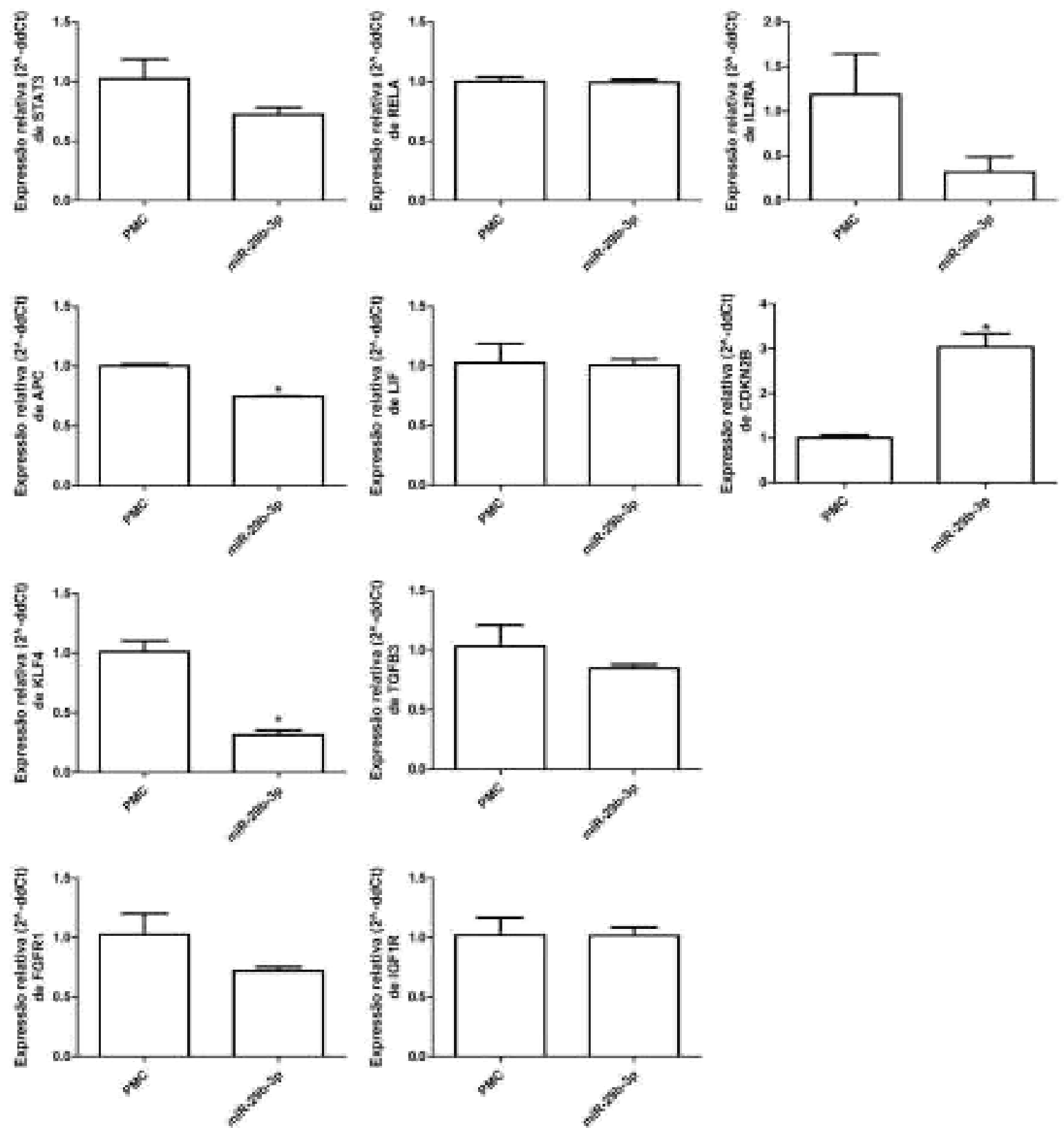

Figura 36. Gráficos de quantificação relativa ( $2^{\wedge}$-ddCt) para os genes STAT3, APC, KLF4, FGFR1, RELA, LIF, $T G F B 3, I G F 1 R, I L 2 R A$ e $C D K N 2 B$ em células NTera-2 transfectadas com miR-29b-3p pelo e incubadas por $48 \mathrm{~h}$ em condições de cultivo, comparadas com células transfectadas com o controle negativo (PMC). Essas análises demonstraram que o miRNA em questão reduziu os níveis transcricionais, de forma estatisticamente significativa $(\mathrm{P}<0,05)$, para $A P C$ e $K L F 4$, e levou a um aumento na quantificação de CDKN2B. * $=\mathrm{P}<0,05$. 

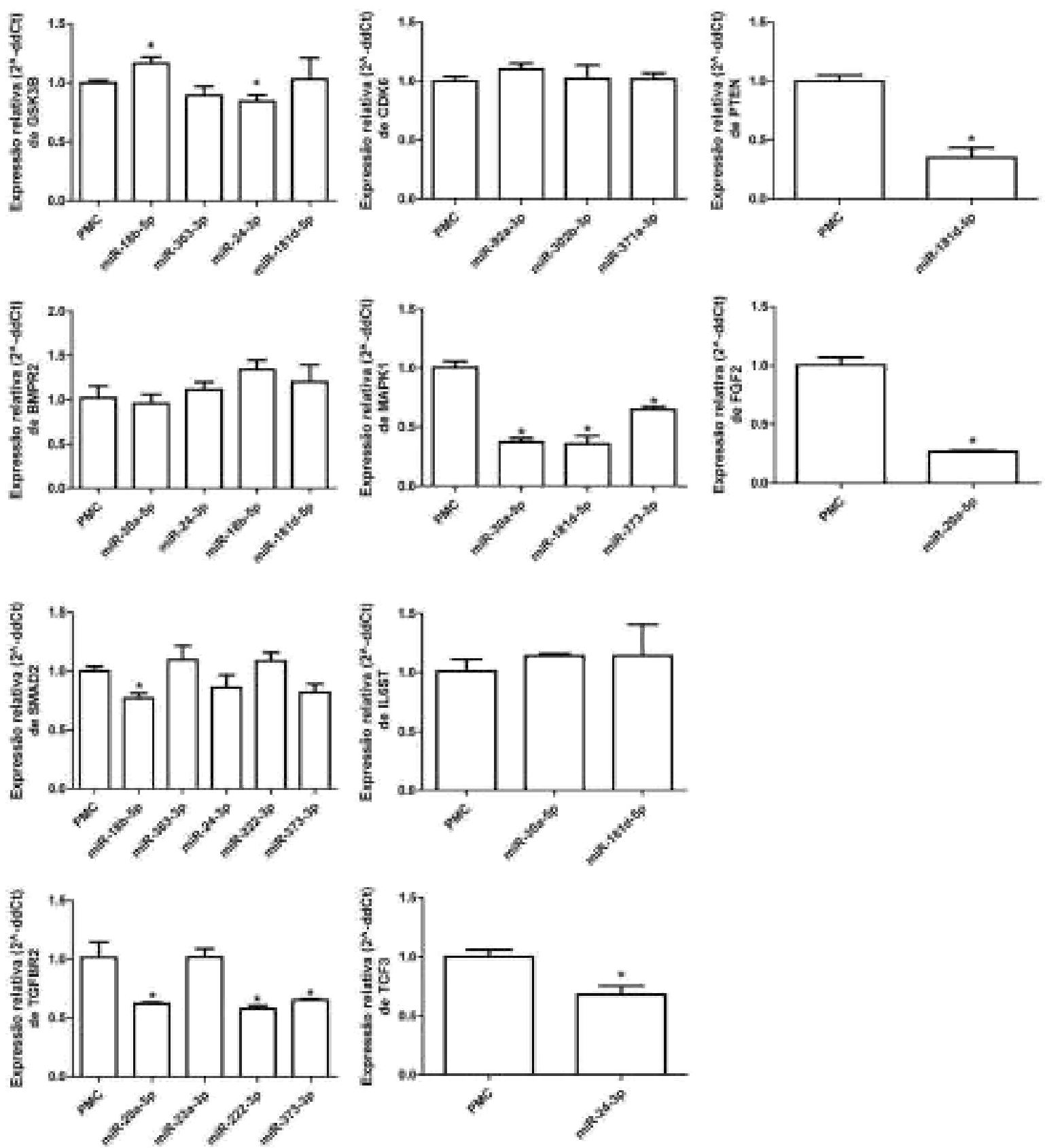

Figura 37. Gráficos de quantificação relativa ( $2^{\wedge}$-ddCt) para os genes $G S K 3 B, B M P R 2, S M A D 2, T G F B R 2$, CDK6, MAPK1, IL6ST, TCF3, PTEN e FGF2 em células NTera-2 transfectadas miR mimics representantes dos miRNAs dos clusters fenotípicos (NTera-2/H1) identificados, sendo eles: miR-18b-5p (B.1/B.1), miR-20a-5p (A1/C1), miR-23a-3p (A.2/C1), miR-24-3p (A.2/B.1), miR-30a-5p (A.2/A), miR-92a-3p (B.2a/C.2c), miR-181d5p (B.2b/C.1), miR-222-3p (B.1/C.2b), miR-302a-3p (B.2a/C.2b), miR-363-3p (B.1/B.1), miR-371a-3p (B.2b/C.2c), miR-373-3p (B.2b/C.2a). Essas células foram cultivadas pelo período de 48h e tiveram seu RNA total extraído, do qual foi feito o cDNA para quantificação por qPCR. As análises foram relativos ao grupo transfectado com a molécula de controle negativo (PMC). Nota-se que alguns miRNAs levaram à redução na quantificação de transcritos para a grande maioria dos genes estudados, resultado este que pode validar a ação dos miRNAs na regulação das vias identificadas pela ferramenta DAVID, a partir da identificação de alvos por uma abordagem in silico. $*=\mathrm{P}<0,05$. 


\subsection{O papel dos miRNA pró-pluripotência na regulação da via Notch}

Para averiguar o possível efeito regulatório de miRNAs que promoveram a pluripotência no ensaio funcional (item 3.4) sobre a via Notch, inicialmente foram identificados os componentes da via na base de dados KEGG (Figura 38).

NOTCA SIGNALING PATHWAP

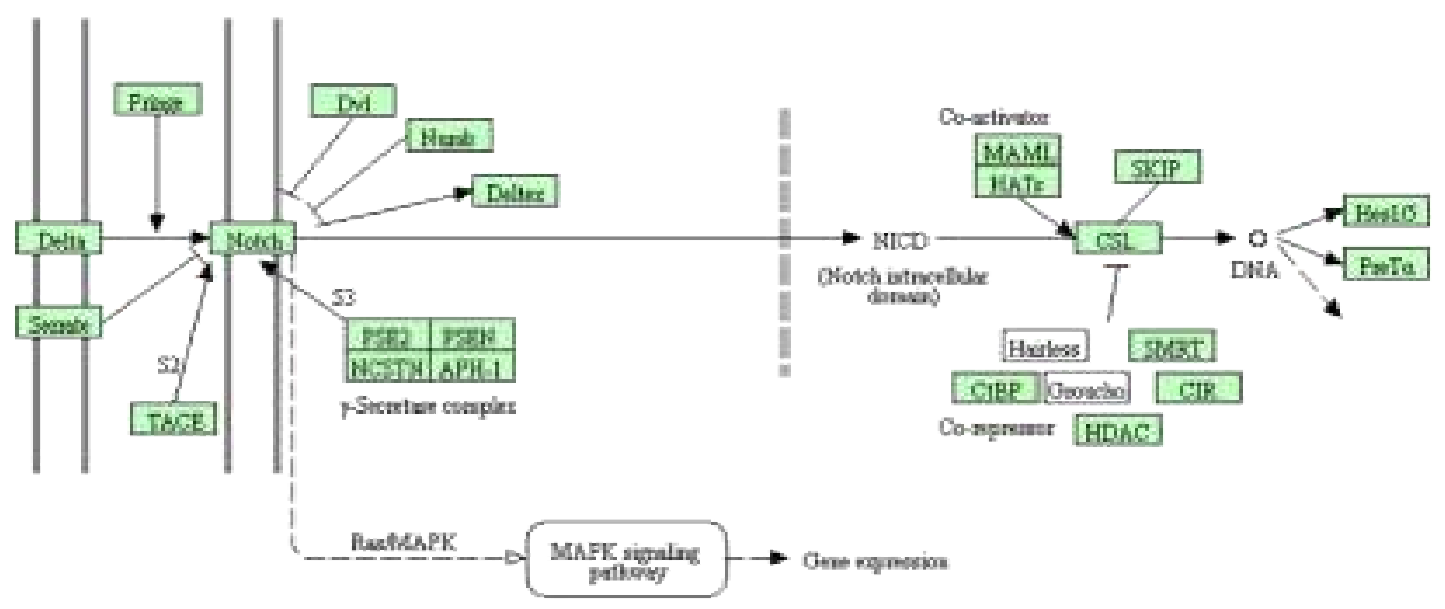

043005917 ?

(e) Kutritive 1 boutaries

Figura 38. Esquema da via de sinalização de Notch obtido pela base de dados KEGG. Nela, podem ser observados os componentes principais da via e como se dá o controle da sinalização, desde sua ativação na membrana até o efeito de regulação transcricional.

Uma vez identificados os genes destes componentes, foi feita a identificação dos miRNAs (do conjunto aqui estudado) que alvejavam estes transcritos, conforme descrito no item 3.9. A Tabela 08 apresenta os resultados desta análise, estando nela descritos os genes da via e os miRNAs que os alvejam.

Tabela 8. Lista de genes componentes da via de sinalização Notch e dos miRNAs que os alvejam. Esta lista foi gerada a partir da informação contida no banco de dados Target Scan 7.

\begin{tabular}{cl}
$\begin{array}{c}\text { Componente } \\
\text { da via Notch } \\
\text { (gene) }\end{array}$ & \multicolumn{1}{c}{ miRNAs que alvejam o gene componente da via Notch } \\
\hline ADAM17 & $\begin{array}{l}\text { miR-101-3p, miR-145-5p, miR-181d-5p, miR-222-3p, miR-23a-3p, miR-24-3p, miR-302a-3p, miR- } \\
\text { 302b-3p, miR-302c-3p, miR-302d-3p, miR-372-3p, miR-373-3p }\end{array}$ \\
APH1A & $\begin{array}{l}\text { miR-145-5p, miR-24-3p, miR-302a-3p, miR-302b-3p, miR-302c-3p, miR-302d-3p, miR-372-3p, miR- } \\
\text { 373-3p }\end{array}$ \\
APH1B & $\begin{array}{l}\text { miR-101-3p, miR-145-5p, miR-17-3p, miR-181d-5p, miR-18a-5p, miR-18b-5p, miR-21-5p, miR-23a- } \\
\text { 3p, miR-24-3p, miR-302c-3p, miR-363-3p, miR-92a-3p }\end{array}$ \\
CIR1 & miR-101-3p, miR-21-5p, miR-302a-5p \\
CREBBP & miR-106a-5p, miR-20a-5p, miR-20b-5p, miR-23a-3p, miR-24-3p, miR-302a-3p, miR-302a-5p, miR- \\
CTBP1 & miR-101-3p, miR-17-3p, miR-302b-5p \\
\hline
\end{tabular}




\begin{tabular}{|c|c|}
\hline СТВP2 & miR-101-3p, miR-181d-5p, miR-18a-5p, miR-18b-5p, miR-23a-3p, miR-302a-5p, miR-302b-5p \\
\hline DLL1 & $\operatorname{miR}-24-3 p, \operatorname{miR}-371 a-3 p$ \\
\hline DLL4 & miR-101-3p, miR-302a-5p, miR-302c-3p, miR-363-3p, miR-92a-3p \\
\hline DTX1 & miR-145-5p \\
\hline DTX2 & miR-363-3p, miR-92a-3p \\
\hline DTX3 & $\operatorname{miR}-24-3 p$ \\
\hline DTX3L & miR-101-3p, miR-17-3p, miR-21-5p, miR-222-3p, miR-24-3p, miR-302b-5p \\
\hline DTX4 & $\begin{array}{l}\operatorname{miR}-145-5 p, \text { miR-17-3p, miR-181d-5p, miR-24-3p, miR-302a-3p, miR-302b-3p, miR-302c-3p, miR- } \\
\text { 302d-3p, miR-363-3p, miR-372-3p, miR-373-3p, miR-92a-3p }\end{array}$ \\
\hline DVL1 & miR-101-3p, miR-18a-5p, miR-18b-5p \\
\hline DVL2 & miR-222-3p, miR-23a-3p \\
\hline DVL3 & $\begin{array}{l}\text { miR-106a-5p, miR-18a-5p, miR-18b-5p, miR-20a-5p, miR-20b-5p, miR-21-5p, miR-24-3p, miR-302a- } \\
\text { 3p, miR-302b-3p, miR-302c-3p, miR-302d-3p, miR-372-3p, miR-373-3p }\end{array}$ \\
\hline EP300 & miR-106a-5p, miR-20a-5p, miR-20b-5p \\
\hline HDAC1 & $\operatorname{miR}-24-3 p$ \\
\hline HDAC2 & $\begin{array}{l}\text { miR-145-5p, miR-17-3p, miR-21-5p, miR-23a-3p, miR-24-3p, miR-302a-5p, miR-302b-5p, miR-363- } \\
\text { 3p, miR-92a-3p }\end{array}$ \\
\hline JAG1 & miR-17-3p, miR-21-5p, miR-23a-3p, miR-302b-5p \\
\hline JAG2 & miR-145-5p, miR-19a-3p, miR-19b-3p, miR-24-3p, miR-302c-3p \\
\hline КАТ ТВ & $\begin{array}{l}\operatorname{miR}-106 a-5 p, \operatorname{miR}-181 d-5 p, \operatorname{miR}-19 a-3 p, \operatorname{miR}-19 b-3 p, \operatorname{miR}-20 a-5 p, \operatorname{miR}-20 b-5 p, \operatorname{miR}-23 a-3 p, \text { miR- } \\
\text { 302a-3p, miR-302b-3p, miR-302c-3p, miR-302d-3p, miR-363-3p, miR-372-3p, miR-373-3p, miR-92a- } \\
\text { 3p }\end{array}$ \\
\hline LFNG & $\operatorname{miR}-24-3 p$ \\
\hline MAML1 & $\begin{array}{l}\text { miR-145-5p, miR-17-3p, miR-19a-3p, miR-19b-3p, miR-222-3p, miR-23a-3p, miR-24-3p, miR-302a- } \\
\text { 3p, miR-302b-3p, miR-302b-5p, miR-302c-3p, miR-302d-3p, miR-372-3p, miR-373-3p }\end{array}$ \\
\hline MAML2 & $\begin{array}{l}\operatorname{miR}-101-3 p, \text { miR-17-3p, miR-23a-3p, miR-302a-3p, miR-302a-5p, miR-302b-3p, miR-302b-5p, miR- } \\
\text { 302c-3p, miR-302d-3p, miR-363-3p, miR-372-3p, miR-373-3p, miR-92a-3p }\end{array}$ \\
\hline MAML3 & $\begin{array}{l}\text { miR-101-3p, miR-145-5p, miR-17-3p, miR-18a-5p, miR-18b-5p, miR-19a-3p, miR-19b-3p, miR-24- } \\
\text { 3p, miR-302a-5p, miR-302b-5p, miR-363-3p, miR-92a-3p }\end{array}$ \\
\hline MFNG & $\operatorname{miR}-302 a-5 p$ \\
\hline NCSTN & $\operatorname{miR}-145-5 p, \operatorname{miR}-24-3 p$ \\
\hline NOTCH1 & miR-101-3p, miR-363-3p, miR-92a-3p \\
\hline NOTCH2 & $\begin{array}{l}\text { miR-101-3p, miR-181d-5p, miR-18a-5p, miR-18b-5p, miR-19a-3p, miR-19b-3p, miR-23a-3p, miR- } \\
\text { 302a-3p, miR-302a-5p, miR-302b-3p, miR-302c-3p, miR-302d-3p, miR-363-3p, miR-372-3p, miR- } \\
\text { 373-3p, miR-92a-3p }\end{array}$ \\
\hline NOTCH3 & $\operatorname{miR}-24-3 p$ \\
\hline NOTCH4 & miR-181d-5p, miR-302a-5p \\
\hline NUMB & miR-101-3p, miR-17-3p \\
\hline NUMBL & $\begin{array}{l}\operatorname{miR}-106 a-5 p, \operatorname{miR}-20 a-5 p, \operatorname{miR}-20 b-5 p, \operatorname{miR}-302 a-3 p, \operatorname{miR}-302 b-3 p, \operatorname{miR}-302 c-3 p, \operatorname{miR}-302 d-3 p \\
\text { miR-372-3p, miR-373-3p }\end{array}$ \\
\hline PSEN1 & $\begin{array}{l}\operatorname{miR}-101-3 p, \operatorname{miR}-106 a-5 p, \text { miR-145-5p, miR-17-3p, miR-181d-5p, miR-18a-5p, miR-18b-5p, miR- } \\
\text { 20a-5p, miR-20b-5p, miR-222-3p, miR-24-3p, miR-302a-3p, miR-302b-3p, miR-302b-5p, miR-302c- } \\
\text { 3p, miR-302d-3p, miR-363-3p, miR-372-3p, miR-373-3p, miR-92a-3p }\end{array}$ \\
\hline PSEN2 & miR-302a-5p \\
\hline RBPJ & $\begin{array}{l}\operatorname{miR}-101-3 p, \operatorname{miR}-181 d-5 p, \operatorname{miR}-18 a-5 p, \operatorname{miR}-18 b-5 p, \operatorname{miR}-21-5 p, \operatorname{miR}-302 a-5 p, \operatorname{miR}-302 b-5 p, \text { miR- } \\
\text { 302c-3p, miR-363-3p, miR-92a-3p }\end{array}$ \\
\hline RBPJL & $\operatorname{miR}-17-3 p$ \\
\hline RFNG & $\begin{array}{l}\operatorname{miR}-17-3 p, \operatorname{miR}-302 a-3 p, \quad \operatorname{miR}-302 a-5 p, \quad \operatorname{miR}-302 b-3 p, \quad \operatorname{miR}-302 c-3 p, \quad \operatorname{miR}-302 d-3 p, \quad \operatorname{miR}-372-3 p \\
\operatorname{miR}-373-3 p\end{array}$ \\
\hline SNW1 & miR-145-5p, miR-302b-5p, miR-302c-3p \\
\hline
\end{tabular}


O ensaio funcional, realizado com células da linhagem NTera-2 transfectadas com miRNAs selecionados e cocultivada com a linhagem OP9-DL1 ou OP9-Ctrl, estão apresentados na Figura 39. Pela alteração na quantidade de OCT4 nuclear, refletida pela intensidade de fluoresência da marcação, pôde-se ver que a indução de Notch por DLL1 causou diferenciação celular na linhagem de CCE (A), já que a presença de OP9-DL1 levou a uma redução de, aproximadamente, $20 \%$ da quantidade de OCT4 nuclear $(\mathrm{P}<0,0001)$. Quanto ao efeito inibidor da via Notch, resultando em manutenção da pluripotência, só foi observado pelo miR-363-3p (B), sendo que a transfecção com este miR mimic manteve uma quantificação de OCT4 nuclear $19 \%$ maior que no controle $(P=0,0022)$. De fato, este miRNA causou uma redução nos transcritos de NOTCH2 $(\sim 15 \%$, C) e PSEN1 $(\sim 56 \%$, $\mathbf{P}<0,05, \mathbf{D}$ ), enquanto nenhum efeito foi observado por outro miRNA (miR-18b) que alveja o mRNA destes componentes de Notch.

A

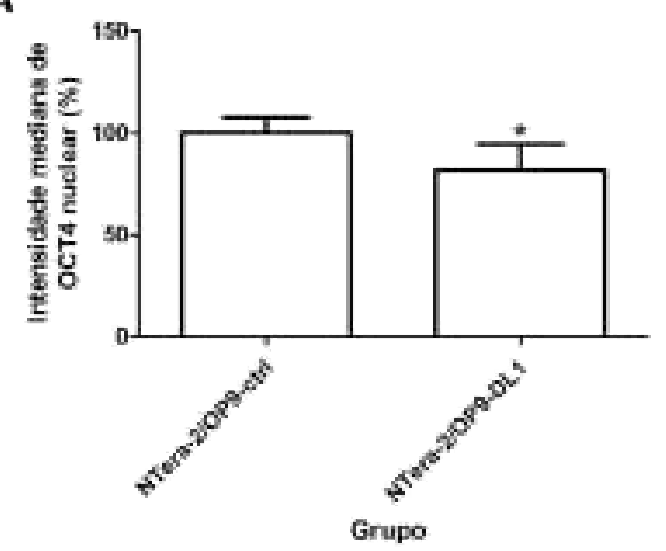

C

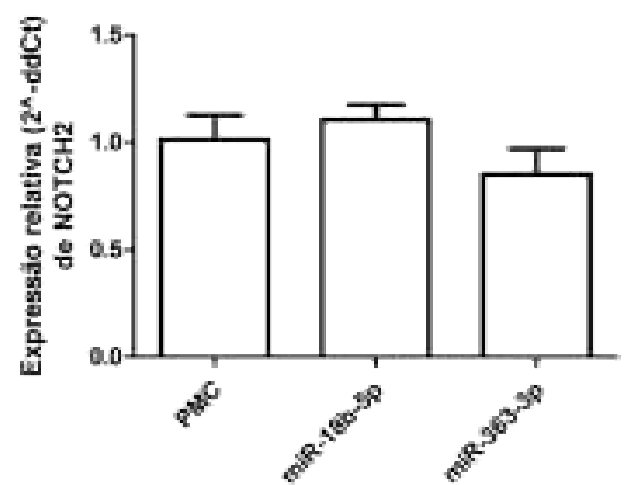

B

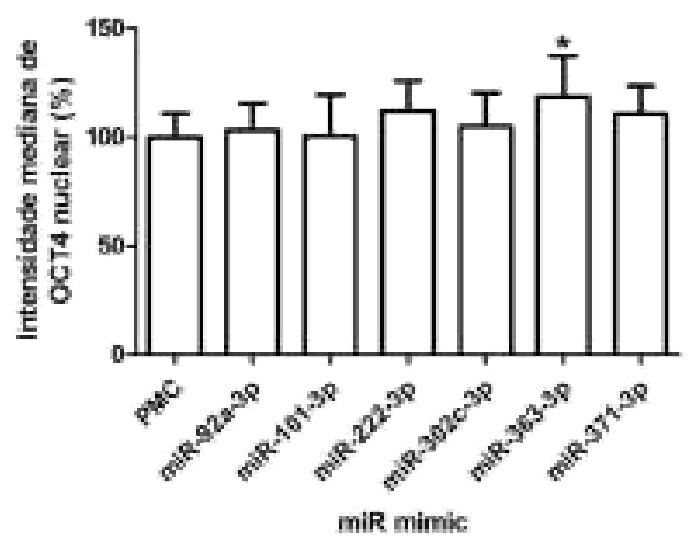

D

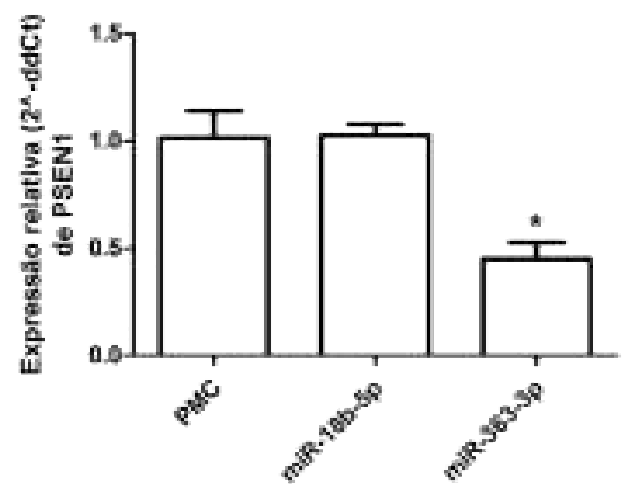

Figura 39. Gráficos apresentando a avaliação do efeito de miRNAs que promoveram características de pluripotência no ensaio funcional sobre a via de sinalização Notch. Estes dados foram obtidos a partir do ganho de função dos miRNAs na linhagem NTera-2, que foi cocultivada com OP9-DL1 ou OP9-Ctrl (A e B), para uma avaliação funcional, ou que teve seu mRNA total extraído após a transfecção, seguida da quantificação de componentes da via Notch (C e D). A) Comparação entre a linhagem NTera-2 transfectada com a molécula de controle negativo (PMC) e cocultivada com as linhagens OP9-ctrl ou OP9-DL1. A quantificação nuclear de OCT4 demonstrou um perda desta proteína no grupo NTera-2/OP9-DL1, indicando um efeito indutor de diferenciação pela ativação de Notch pelo ligante DLL1. B) A comparação entre células NTera-2 transfectadas 
com os diferentes miRNAs e com o PMC, posteriormente cocultivadas com OP9-DL1, demonstrou que o miR363-3p induziu um efeito protetor sobre a diferenciação celular induzida por Notch. C) A quantificação dos transcritos de NOTCH2 demonstrou uma diminuição em células NTera-2 transfectadas com o miR-363-3p, em comparação ao controle negativo (PMC). D) O nível de transcritos de PSEN1 foi reduzido de modo significativo $(\mathrm{P}<0,05)$ em culturas de NTera-2 transfectadas com o miR-363-3p, em comparação à transfecção com PMC. 
5. Discussão 


\subsection{NTera-2 e H1 como modelos de estudo da pluripotência}

Neste trabalho nós identificamos alvos e vias de sinalização cuja regulação póstranscricional por diferentes microRNAs seriam responsáveis pela modulação de características fenotípicas associadas à pluripotência de células tronco embrionárias (CTEh $\mathrm{H} 1$ ), bem como de carcinoma embrionário humano (CCE NTera-2).

As linhagens de CTE e CCE apresentam grande similaridade no padrão de expressão gênica (SPERGER et al., 2003), semelhanças essas que também se mantém quando comparado o perfil proteômico de células de ambas as origens, onde marcadores conhecidamente expressos em CTE apresentam níveis protéicos muito próximos em CCE, como o LIN28 e THY. Apesar disto, é importante salientar que diferenças também são encontradas, como exemplo, as CTE apresentam uma maior quantidade das proteínas DNMT3B e CTNNB1, enquanto CCE apresentam elevados níveis de algumas proteínas relacionadas com alguns tipos de câncer (CHAERKADY et al., 2010; DORMEYER et al., 2008).

No que diz respeito direto à comparação entre as linhagens de células pluripotentes NTera-2 e H1, existe uma grande concordância entre os transcritos de mRNAs encontrados, mas o perfil transcricional de ambas células difere o bastante para que sejam separadas em uma análise de clusterização não-supervisionada. Essa diferença se dá, principalmente, pela expressão de marcadores de células germinativas expressos na linhagem de CCE (LIU et al., 2006). Quanto ao padrão de expressão de miRNAs, a similaridade entre linhagens de CTEh e a NTera-2 é modesta, porém com grande concordância entre miRNAs sabidamente relacionados com a pluripotência, como os miRNA da família do miR-302 (STADLER et al., 2010). Essas diferenças em nível de transcripitoma (mRNAs e miRNAs) e proteoma, podem ser também relacionadas à grande instabilidade genômica/cromossômica apresentada nas CCE, onde comumente são encontradas alterações cromossômicas estruturais e numéricas (BLELLOCH et al., 2004; PLAIA et al., 2006).

Nos ensaios de ganho de função de miRNAs realizados no presente trabalho, foram detectadas algumas diferenças de resposta entre as linhagens H1 e NTera-2. Dos 31 miRNAs estudados, 25 apresentaram resultados similares e os 6 restantes reagiram de maneira oposta (Figura 19A). Dadas as diferenças entre CTE e CCE apresentadas anteriormente, pode-se dizer que houve uma grande concordância entre as respostas das células frente aos tratamentos, o que valoriza os dados encontrados, demonstrando robustês no ensaio desenvolvido e aqui apresentado. 
Do grupo de miRNAs divergentes, 5 deles induziram alterações fenotípicas condizentes com perda de pluripotência na NTera-2, mas não na H1, sendo eles o miR-19a$3 p$, miR-19b-3p, miR-20a-5p, miR-20b-5p e miR-21-5p. De fato, é descrito na literatura um ligeiro aumento da expressão dos quatro primeiros miRNAs citados em culturas de NTera-2 tratadas com atRA (SEMPERE et al., 2004). Do mesmo modo, a indução de diferenciação em CTE também resulta num maior nível de expressão do miR-21-5p (GU et al., 2016; STADLER et al., 2010).

Em contrapartida, o miR-17-5p induziu um aumento na intensidade de OCT4 no núcleo de células NTera-2, enquanto que, para a linhagem H1levou a uma leve redução neste parâmetro. Apesar deste microRNA ser reprimido em CTEh sob diferenciação (STADLER et al., 2010), nossos reresultados estão em linha com dados da literatura, que mostraram um efeito pró-diferenciação do miR-17-5p em CTE, bem como também do miR-20a-5p; neste ultimo caso, diferente dos nosso resultados para a linhagem H1 (GU et al., 2016). O miR-17$5 \mathrm{p}$ se encontra em altos níveis em NTera-2 indiferenciada, assim como em outros tipos tumorais malignos (GALLAGHER et al., 2009); assim, os efeitos opostos deste miR em ambas as linhagens podem advir de diferenças relativas a vias aberrantes presentes na CCE.

Em sua maioria, os efeitos funcionais observados dos miRNAs avaliados corroboraram os efeitos esperados, tendo em vista as hipóteses subjacentes ao critério de seleção descrito na Tabela 1; mais especificamente, de que microRNAs altamente expressos em células pluripotentes e/ou reprimidos mediante a diferenciação estariam funcionalmente associados à manutenção da pluripotência, enquanto que microRNAs induzidos durante a diferenciação estariam envolvidos em processos opostos. De fato, somente 5 dos miRNA apresentaram uma resposta não esperada (Figura 19B). Dentre estes, se encontra o miR-18a$5 \mathrm{p}$, que apesar de seu comportamento relacionado à pluripotência no trabalho de Stadler e colaboradores (2010), apresentou níveis aumentados no processo de diferenciação de CTE para células beta pancreáticas (COSKUN; ERCIN; GEZGINCI-OKTAYOGLU, 2017).

Para o miR-145-5p, o resultado encontrado foi inesperado, pois, nas condições aqui utilizadas, promoveu características compatíveis com pluripotência, mas este miRNA é sabidamente envolvido na indução da diferenciação celular, tendo seus níveis aumentados durante este processo e regulando negativamente a tradução de OCT4, SOX2 e KLF4 (XU et al., 2009). Ainda, o uso do inibidor deste miRNA tem um efeito positivo sobre a reprogramação nuclear, aumentando a eficiência de obtenção de iPSC (BARTA et al., 2016). Estes resultados contraditórios podem advir dos diferentes métodos utilizados para avaliar o ganho de função do miR-145-5p, uma vez que nós utilizamos a transfecção de moléculas 
miméticas (e portanto, com um efeito de repressão transiente), enquanto que $\mathrm{Xu}$ e colaboradores transduziram as células com vetores lentivirais, avaliando a população isolada superexpressando o microRNA. Assim, os níveis extremamente e constantemente elevados deste miR nas CTE podem ter um efeito liquido resultante diferente sobre seus alvos.

Outros dois miRNAs que apresentaram uma atividade pró-pluripotência nos ensaios funcionais, tendo efeito contrário ao esperado pelo observado no trabalho de Stadler e colaboradores (2010), foram os miR-181d-5p e miR-222-3p. Para o primeiro, é descrito na literatura que, o ganho de função deste miRNA promove melhoria na eficiência de reprogramação nuclear induzida por OSK (OCT4, SOX, KLF4), sendo que todos os miRs da família miR-181 são induzidos ao longo da reprogramação mediada por OSK, sendo reprimidos nas iPSCs geradas (JUDSON et al., 2013). Ainda, o promotor do locus miR181c\&d é ligado por OCT4, SOX2 e NANOG, sendo induzido durante a reprogramação mediada por OSK e cMyc, enquanto o miR-181a e miR-181b são reprimidos (CHEN et al., 2012a). Assim, apesar de Stadler e colaboradores (2010) terem identificado a indução deste microRNA mediante a diferenciação, e do miR-181 estar envolvido na diferenciação de células musculares (NAGUIBNEVA et al., 2006) e linfócitos B (CHEN, 2004) fica claro que sua atuação pode ter um papel distinto associado à pluripotência em determinadas situações. No que se refere ao miR-222-3p, este miRNA é relacionado a células-tronco adultas (MATHIEU; RUOHOLA-BAKER, 2013; REN et al., 2009), sendo também associado com a diferenciação terminal completa de miocitos (CARDINALLI et al., 2009), mais uma vez revelando a flexibilidade do papel mediado por determinados microRNAs em diferentes contextos.

\subsection{Regulação da transição epitelial-mesenquimal por miRNAs capazes de promover diferenciação em células pluripotentes humanas}

O processo de transição epitelial-mesenquimal (EMT) é designado por um conjunto de modificações transcricionais, morfológicas e estruturais, pelo qual uma célula de fenótipo epitelial altera sua capacidade de adesão e motilidade, adquirindo assim características mesenquimais (HAY, 1995). Este fenômeno é conhecidamente envolvido em processos fisiológicos e patológicos, incluindo a embriogênese, progressão do câncer e diferenciação de células-tronco pluripotentes (EASTHAM et al., 2007; SHOOK; KELLER, 2003; TSUJI; IBARAGI; HU, 2009). 
Diversos são os mecanismos envolvidos no controle da EMT, como fatores de transcrição, moduladores epigenéticos e miRNAs (CICCHINI et al., 2015; DE CRAENE; BERX, 2013; GALVÁN et al., 2015; HUA et al., 2011; PAN et al., 2017; ZHOU et al., 2015). Estes reguladores atuam, por exemplo, induzindo o rearranjo do citoesqueleto de actina, alterações na composição dos receptores de matriz extracelular, levando assim à perda da adesão focal e, consequentemente, da polaridade apical-basal das células epiteliais (LAMOUILLE; XU; DERYNCK, 2014; THIERY et al., 2009; TOJKANDER; GATEVA; LAPPALAINEN, 2012).

No presente estudo, a análise de enriquecimento funcional (por meio da ferramenta DAVID) de alvos compartilhados dos clusters de miRNAs que induziram modificações fenotípicas similarmente associadas à diferenciação, resultou na identificação das vias biológicas de regulação do citoesqueleto de actina, de receptores da matriz extracelular e da adesão focal. Estes clusters (em NTera-2: A.2 e A.3; em H1: A e B.2) mapresentaram um efeito compatível com perda da pluripotência tanto na linhagem NTera-2, quanto na H1, e incluem, por exemplo, os miR-21-3p, miR-27a-3p, miR-29a-3p, miR-29b-3p. Na literatura, o miR-21 é descrito por sua atividade pró-EMT em células tumorais, sendo que sua presença induz diminuição nos níveis de E-caderina (marcador de células epiteliais) e aumento de Ncaderina e Vimentina (marcadores de células mesenquimais) (BORNACHEA et al., 2012; LIU et al., 2015). Para os miR-27a-3p e miRs-29a/b-3p, também são descritas propriedades de indução de EMT em células tumorais, sendo a atividade do primeiro relacionada ao alvejamento de APC, enquanto no caso dos miRs-29a/b, estaria ligada ao efeito regulador destes miRNAs sobre as DNMTs e TET1, e consequente modulação do estado epigenético destas células (CICCHINI et al., 2015; PEI; LEI; LIU, 2016; ZHANG et al., 2011), bem como pela provável ativação da via Wnt/Beta-Catenina (FRÁGUAS et al., 2017).

É importante notar que alguns miRNAs destes clusters citados também causam bloqueio de EMT em outros tipos celulares e situações diferentes (PARK et al., 2017; WANG et al., 2014; ZHAO et al., 2016), mostrando a relevância do contexto celular em que se encontra o miRNA para desempenhar seu efeito funcional e fenotípico. Por fim, em CTE, a diferenciação celular induzida por estes miRNAs foi identificada por diferentes grupos de pesquisa, e embora os mecanismos que levaram a este efeito não tenham sido diretamente ligados à EMT, este processo não pode ser desvinculado da diferenciação em células-tronco pluripotentes (CUI et al., 2016; MA et al., 2015; TU et al., 2015).

Outro grupo de miRNAs, agora relacionados com promoção de características pluripotentes, foi identificado como alvejando componentes da via de sinalização do VEGF. 
A ativação desta via é capaz de induzir EMT pela ativação da via do TGF $\beta$ e indução da expressão de SNAIL, fator de transcrição sabidamente relacionado com o processo em questão (GONZALEZ-MORENO et al., 2010; WANAMI et al., 2008). De fato, sabe-se que alguns miRNAs que integram este cluster (B.2b de NTera-2), como os miR-181d-3p, miRs302 e miR-372-3p, têm efeito inibidor sobre a EMT ou ainda podem induzir o processo inverso, a MET, evento este importante para a indução de pluripotência em células somáticas (JUDSON et al., 2013; SUBRAMANYAM et al., 2011; TAKAHASHI; YAMANAKA, 2006; WANG et al., 2015a). Entretando, a inibição da via VEGF ainda não foi descrita como um mecanismo de repressão de EMT por estes miRNAs.

\section{3 miRNAs que regulam o complexo RISC promovem perfís fenotípicos associados à pluripotência em células pluripotentes humanas}

Como já apresentado neste trabalho, os miRNAs desenvolvem papéis importantes nos mais diversos processos biológicos, sejam eles fisiológicos ou patológicos, incluindo nesta lista a manutenção do fenótipo pluripotente e a diferenciação celular (ANOKYE-DANSO et al., 2011; LAKSHMIPATHY et al., 2007; LAURENT et al., 2008; MALLICK; CHAKRABARTI; GHOSH, 2011; REN et al., 2009). Durante sua biogênese, essas pequenas moléculas são inicialmente transcritas por RNA polimerases em sequências, em geral, muito maiores (os pri-miRNAs) que os miRNAs maduros, que possuem apenas cerca de 22 nt. No seu processo de maturação, essas moléculas são processadas, principalmente por duas RNases do tipo III, Drosha e Dicer, antes de se acoplarem ao complexo RISC (que inclui proteínas do tipo Ago), gerando o miRISC, real efetor da regulação pós-transcricional induzida pelos miRNAs (GRISHOK et al., 2001; HAN et al., 2004; HUTVÁGNER et al., 2001; LEE; FEINBAUM; AMBROS, 1993; SIOMI; SIOMI, 2010).

Buscando entender melhor o papel desses RNAs reguladores nas células pluripotentes, foram produzidas linhagens de CTE knockout para DICER ou DGCR8, que atua em conjunto com Drosha (KANELLOPOULOU et al., 2005; WANG et al., 2007). Embora essas células não fossem competentes para a geração de miRNAs funcionais, elas se mantiveram viáveis e expressando os marcadores de pluripotência. Entretanto, com a ausência de miRNAs maduros, essas CTE apresentaram alterações no tempo de duplicação, se tornando mais lentas, e perderam sua capacidade de diferenciação celular, pois falharam em gerar quimeras, teratomas ou células dos folhetos embrionários in vitro, pela técnicas de corpos embrióides. Elas também mostraram resposta lenta ao estímulo de diferenciação, com perda lenta dos 
marcadores de pluripotência. Este conjunto de resultados demonstrou que os miRNAs, embora desempenhem papéis importantes nas células pluripotentes, não são indispensáveis para a manutenção do fenótipo indiferenciado, mas sim para a diferenciação celular.

Neste sentido, o ensaio funcional realizado permitiu a observação de grupos de miRNAs que promoveram características de pluripotência e, a análise dos alvos compartilhados entre estes e as possíveis vias por eles reguladas resultou na identificação da via de Dicer como provavelmente modulada. Os transcritos de Ago são alvos dos miRNAs destes clusters (em NTera-2: B.2a e B.2b; em H1: C.1, C.2b e C.2c), que incluem, dentre outros, os miRs-302 e os do cluster miR-371, os quais são altamente expressos em células pluripotentes humanas (LAKSHMIPATHY; DAVILA; HART, 2010; STADLER et al., 2010; SUBRAMANYAM et al., 2011). Sabendo-se que as proteínas Ago são extremamente importantes para a montagem do miRISC, sendo cruciais para a atividade dos miRNAs (WANG et al., 2012), um hipotético knockdown destas proteínas causado pelos miRNAs com ação pró-pluripotência poderia levar a uma redução da disponibilidade de RISC para associarse com miRNAs que agiriam induzindo diferenciação celular, sem comprometer o fenótipo pluripotente. Este mecanismo se torna uma real possibilidade, já que a regulação mediada por estes pequenos RNAs é de natureza altamente quantitativa e que depende das concentrações citoplasmáticas dos miRNAs em questão e seus alvos (MUKHERJI et al., 2011).

\subsection{Regulação de PI3K-AKT e mTOR por miRNAs pode induzir diferenciação celular ou características relacionadas pluripotência em células-tronco humanas}

Dentro das vias identificadas como possivelmente reguladas pelos diferentes clusters fenotípicos de miRNAs estudados, estão as vias de PI3K-AKT, mTOR, FOXO e RAS, sendo algumas delas detectadas em ambos os grupos de miRNAs pró e anti-pluripotência. Sabe-se que as vias de sinalização de PI3K-AKT e mTOR atuam em diversos processos importantes nas funções celulares, como reações anabólicas, crescimento e sobrevivência celular, e a perda de componentes chaves destas vias pode levar à incompatilidade com a vida (MURAKAMI et al., 2004; PENG et al., 2003; SINGH et al., 2012; YU et al., 2015b; YU; CUI, 2016). Em CTE, a inibição de PI3K resulta na perda de características de pluripotência e expressão de genes relacionados com o comprometimento celular (ARMSTRONG et al., 2006; MCLEAN et al., 2007; SINGH et al., 2012) e o knockout de PTEN, que age se contrapondo à $\mathrm{PI} 3 \mathrm{~K}$, tem um efeito positivo sobre a proliferação e sobrevivência destas células (ALVA et al., 2011). Em CTEh, o mecanismo proposto de manutenção da 
pluripotência por PI3K parece estar relacionada não somente à inibição de MAPK/ERK, mas também à supressão da atividade de $\beta$-catenina por atuação de GSK3, uma vez que $\beta$-catenina participa da expressão de genes relacionados com a diferenciação celular (DAVIDSON et al., 2012; SINGH et al., 2012).

A via de mTOR também tem sido relacionada com o status pluripotente, sendo que sua inibição leva à perda da pluripotência em CTEh, enquanto o knockdown de supressores fisiológicos da via previne a diferenciação celular (BETSCHINGER et al., 2013; ZHOU et al., 2009). Esta via age em conjunto com PI3K-AKT para regular o metabolismo glicolítico aeróbico, estimulando a expressão de transportadores de glicose e enzimas glicolíticas, embora ambém participe da produção de proteínas envolvidas com a função mitocondrial e com o metabolismo oxidativo (CHENG et al., 2014; KIM et al., 2006; MORITA et al., 2013; WARD; THOMPSON, 2012). Assim, essas vias participam da manutenção da pluripotência também pela regulação do metabolismo celular, sendo a via glicolítica anaeróbica a principal provedora de energia em células pluripotentes, sendo rapidamente substituída pela fosforilação oxidativa quando estas células são submetidas a um estímulo de diferenciação (MOUSSAIEFF et al., 2015; ZHOU et al., 2012b).

Dentro dos clusters que induziram diferenciação celular em ambas as linhagens utilizadas no presente estudo (em NTera-2: A.1, A.2 e A.3; em H1: B.2), as vias PI3K-AKT e mTOR foram encontradas como possivelmente reguladas. De fato, diferentes estudos já relataram o controle de miRNAs sobre PI3K/AKT/mTOR (BAI et al., 2015; JIANG et al., 2017; JOSSE et al., 2014), além disso, alguns representantes dos clusters fenotípicos em questão, como os miR-27a-3p, miRs-29a/b-3p e miR-30a-5p, atuam diretamente sobre transcritos de componentes destas vias, inibindo-as em diferentes modelos de células humanas (LIU et al., 2013; MENG et al., 2016; YANG et al., 2013; YU et al., 2015a; ZHONG; BIAN; WU, 2013). Adicionalmente, sabe-se que a via de IGF-1, a qual atua como indutora de PI3K e na manutenção de pluripotência (HUANG et al., 2009; SINGH et al., 2012), é inibida por ação dos miRs-29 (HAND et al., 2012; WANG et al., 2015c), e foi identificada pelo ensaio funcional (realizado no presente estudo) como possivelmente regulada no cluster pelos miRs29a/b-3p, por via da inibição do próprio IGF1, que se liga aos receptores de membrana, e de componentes intracelulares como IRS-1, (receptor de insulina, que pode ativar PI3K), GAP (proteínas ativadoras de GTPase) e c-FOS (fator de transcrição ativado pela via). Dito isso, a inibição dessas vias poderia pelos miRNAs pode ser um dos mecanismos por onde induzem a diferenciação em células pluripotentes humanas. 
Alguns dos clusters fenotípicos de miRNAs que induziram características de pluripotência também apresentaram uma possível modulação das vias PI3K-AKT e mTOR (em NTera-2: B2.a; em H1: B.1, C.1, C.2a e C.2b). Dentro dos alvos detectados nas vias, está o supressor tumoral PTEN, que é um antagonista de PI3K-AKT. O miR-222-3p, componente do cluster fenotípico C.2b da linhagem H1, possui atividade inibitória sobre PTEN, agindo assim como um onco-miR (CHUN-ZHI et al., 2010; SHEN et al., 2017; WANG et al., 2016). O miR-181d-5p, representante do cluster C.1 em H1, onde foram induzidas características de pluripotência, também apresenta atividade inibitória sobre este supressor tumoral (HENAOMEJIA et al., 2013) e induziu uma diminuição nos níveis do transcrito de PTEN quando transfectado na linhagem NTera-2 (Figura 37). Juntos, estes dados corroboram com uma hipótese de promoção de pluripotência pelos miRNAs dos clusters com atividade própluripotência, detectados como modulares das vias de sinalização em questão, por meio da inibição de PTEN.

\section{5 miRNAs promovem diferenciação celular por inibição seletiva de componentes da via TNF e atuam sobre a via dos Toll-like receptors para promoverem pluripotência}

A via do TNF é composta por citocinas e outras proteínas que, quando ativadas, induzem atividades pró-inflamatórias e apoptose. Esta via pode ser ativada de diferentes formas, inclusive por ação dos Toll-like receptors (TLR), que compreendem uma família de proteínas, inicialmente descobertas em Drosophila melanogaster, as quais desempenham papel importante na resposta do sistema imune inato frente a diferentes patógenos (LOCKSLEY; KILLEEN; LENARDO, 2001; ROCK et al., 1998; YEH et al., 2016). É sabido que, durante a cultura, um grande número de CTEh sofre apoptose, bem como diferenciação espontânea (AMIT et al., 2000; XIAO; YUAN; SHARKIS, 2006) e isso pode ser relacionado à atividade de P53, que é ativada por TNF (GORETSKY et al., 2012). A inibição de P53 em CTEh leva a um aumento na sobrevivência celular, enquanto a superexpressão desta proteína, além de morte celular, também induz diferenciação nestas células (QIN et al., 2007).

A ativação da via dos TLR se dá com interação destes receptores e diferentes ligantes,

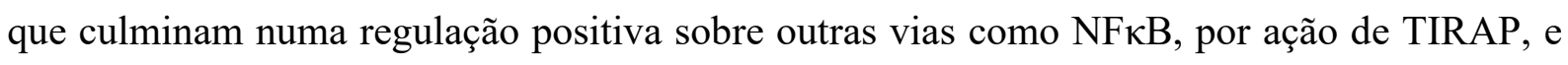
das MAPK, que participam da regulação do ciclo celular, expressão gênica e diferenciação celular (CHUANG; BARGMANN, 2005; SUN et al., 2015; YAMAMOTO et al., 2002). A proteína P38, uma das MAPKs de células de mamíferos, é ativada pela via de TLR por meio 
da ação de MAPKKs, como a MEK6 (MORIGUCHI et al., 1996), e é sabidamente envolvida na diferenciação celular de CTE e CCE, participando do comprometimento com a linhagem mesodermal (BARRUET et al., 2011; DAVIDSON; MORANGE, 2000; HADJAL et al., 2013).

No trabalho aqui apresentado, essas vias também foram identificadas como moduladas por alguns dos clusters fenotípicos, que foram definidos nos ensaios funcionais com miR mimics. Tanto na linhagem NTera-2, quanto na H1, clusters que induziram características de diferenciação tiveram como alvo componentes da via do TNF (em NTera-2: A.1 e A.3; em H1: B.2). Dentre estes alvos, encontram-se fatores importantes para a ativação de PI3K-AKT, a qual já foi apresentada anteriormente como importante para a manutenção da pluripotência, e que também pode ser ativada por TNF (SANDRA et al., 2002). Outro alvo comum entre alguns destes miRNAs, dentro da via de TNF, é a Caspase 8, proteína indispensável para a indução de pluripotência em células somáticas (LI et al., 2010). Entre os miRNAs pródiferenciação que apresentaram possível regulação sobre TNF, encontram-se os miRs-29a/b$3 p$ e miR-22-3p. Além de sua atividade inibitória sobre PI3K-AKT (YU et al., 2015a), a modulação da via TNF pelo miR-29 também já foi descrita (LI; ZHANG; GU, 2015), enquanto o miR-22 apresenta atividade anti-tumoral por repressão de CREB, outro componente desta via que participa da proliferação de células-tronco neurais (BLECKMANN et al., 2002; FUSCO et al., 2016; JIANG et al., 2016). Sendo assim, esse miRNAs podem agir em componentes da via TNF que possam desempenhar alguma ação favorável à pluripotência, mantendo assim somente os componentes que atuem induzindo a diferenciação celular.

Em relação aos clusters fenotípicos com características de pluripotência, a via dos TLR se mostrou possívelmente regulada pelos miRNAs que os compõe (em NTera-2: B.2a; em H1: C.2a). Um dos alvos comuns entre miRNAs destes clusters é a MEK6, o que pode levar a uma proposta de promoção de pluripotência por inibição desta proteína e, consequentemente, de P38, já que estes atuam como promotores da diferenciação celular (BARRUET et al., 2011; DAVIDSON; MORANGE, 2000; HADJAL et al., 2013).

Sabe-se que os miR-92a-3p e miR-106a-5p desempenham papéis de onco-miRs e uma das vias pelas quais atuam é inibindo a atividade dos TLR por inativação de proteínas da família de MEK6, podendo assim agir sobre os níveis de P38, porém não foi observada a inibição de P38 nos casos estudados (ANTOON et al., 2013; HONG et al., 2010; LAI et al., 2013; OEZTUERK-WINDER et al., 2012). De fato, existe uma correlação inversamente proporcional entre a atividade de P38 em células tumorais e miR-92a-3p e miR-106a-5p, uma vez que a ausência de P38 induz aumento nas quantificações destes miRNAs e, na situação 
inversa, estes se encontram aumentados (ANTOON et al., 2013; HONG et al., 2010; LAI et al., 2013; OEZTUERK-WINDER et al., 2012). Situação similar é vista com o miR-373-3p, o qual também faz parte destes clusters fenotípicos, que é capaz de induzir efeitos opostos à P38 quando superexpresso em cardiomiócitos, sendo que o efeito direto sobre a expressão desta proteína não foi avaliado (SHEN et al., 2011). A ação inibitória dos miRNAs dos clusters fenotípicos em questão sobre a via de TLR, por supressão de MEK6 e P38 é uma hipótese plausível, mesmo com os detalhes observados neste parágrafo, já que, em alguns casos citados, não foi avaliada a ação inibitória do miRNA diretamente sobre P38, e além disso, os estudos não foram realizados em células pluripotentes e o contexto celular tem grande influência sobre os mecanismos moleculares regulando vias celulares, como já foi discutido anteriormente.

\section{6 miRNAs induzem diferenciação celular ou pluripotência por modulação das vias WNT e TGF $\beta$}

Como apresentado anteriormente, as vias de sinalização de WNT e TGF $\beta$ desempenham papel ambíguo em células pluripotentes, pois enquanto parte da via é voltada para a manutenção do fenótipo pluripotente, outros componentes atuam na indução da diferenciação e comprometimento celular (SAKAKI-YUMOTO; KATSUNO; DERYNCK, 2013; ZHANG et al., 2013). A ativação da via canônica de WNT promove pluripotência por inibir a ação de GSK3, promovendo assim o acúmulo de $\beta$-catenina, a qual migra para o núcleo e, ao se complexar com membros da família TCF/LEF ou ainda com OCT4, se liga no DNA, promovendo a expressão de genes relacionados com o estado indiferenciado nas CTE (ABERLE et al., 1997; ANTON et al., 2007; KELLY et al., 2011). Em contraparte, é descrito que a ativação desta via durante a manutenção de CTE levou à perda de autorrenovação, dos marcadores de pluripotência e à diferenciação para mesoderma e trofectoderma (BAKRE et al., 2007; DAVIDSON et al., 2012; HE et al., 2008; LINDSLEY et al., 2006; LYASHENKO et al., 2011). Além disso, em condições em que a via WNT foi estimulada por longo período em culturas de CTEh, concomitantemente ao tratamento com inibidores de $\beta$-catenina, não foi observada a perda do status indiferenciado dessas células e, adicionalmente, foi também descrito que a via WNT/ $\beta$-catenina é dispensável para a manutenção da pluripotência, sendo reprimida por ação de OCT4 (DAVIDSON et al., 2012).

Os ligantes do tipo TGF- $\beta$ s, activinas, nodal, GDFs e BMPs fazem parte da família de componentes da via de sinalização de TGF $\beta$, que uma vez ativada regula diferentes processos 
celulares que incluem eventos de diferenciação (ANNES; MUNGER; RIFKIN, 2003; SAKAKI-YUMOTO; KATSUNO; DERYNCK, 2013; SHI; MASSAGUÉ, 2003; WU; HILL, 2009). A atividade pró-pluripotência desta via se dá por TGFß/Activina/Nodal, que leva à fosforilação de $\operatorname{Smad} 2 / 3$, resultando em sua ativação e migração para o núcleo, onde se ligará à região promotora de $N A N O G$, regulando positivamente a expressão deste, que é um dos fatores centrais na manutenção do fenótipo pluripotente (VALLIER et al., 2009; XU et al., 2008). Por outro lado, a ativação da via TGF $\beta$ por BMP, que pode resultar na ativação de Smad1, 5 e 8, induz a diferenciação em CTEh para linhagens de trofectoderma, endoderma, mesoderma e até ectoderma, em diferentes condições (LEUNG; KENT MOREST; LI, 2013; LI et al., 2013; PERA et al., 2004; RICHTER et al., 2014; TEO et al., 2012; ZHANG et al., 2008). Interessantemente, activina e nodal podem levar a diferenciação celular em CTEh em conjunto com a supressão da via PI3K-AKT, originando endoderma definitivo (MCLEAN et al., 2007).

Com estas informações, podemos chegar à conclusão de que os níveis dos componentes das vias de WNT e TGF $\beta$, em células pluripotentes, devem sofrer uma regulação fina, a qual é associada com o papel de regulação dos miRNAs sobre a expressão gênica. A identificação dos clusters fenotípicos pela análise multiparamétrica revelou que alguns miRNAs devem agir sobre essas vias tanto para manutenção do status pluripotente, quanto para indução de diferenciação celular.

Exemplos de miRNAs componentes dos clusters fenotípicos que promoveram pluripotência por possível modulação de WNT e TGF $\beta$ são os miR-181d-5p, miR-302a/b3p/5p e miR-373-3p. Dentre outros, os miRNAs destes clusters (em NTera-2: B.2b; em H1: B.1, C.1, C.2a e C.2b) têm como alvo FZD4 e GSK3, da via WNT, e BMPR, ACVR, receptores de Nodal, da via TGF $\beta$, e assim, propõe-se que o mecanismo de promoção de pluripotência por estes miRNAs se dê pela inativação de sinais de diferenciação por WNT, como a ativação de FZD4 na geração de cardiomiótitos (MAZZOTTA et al., 2016), e por TGF $\beta$, como no efeito pró-diferenciação das BMPs (RICHTER et al., 2014), permitindo somente uma regulação positiva destas vias sobre a pluripotência. Um exemplo prático desta hipótese de mecanismo é a participação do miR-181 na reprogramação por meio da ativação de WNT, levando ao acúmulo de $\beta$-catenina nuclear, e inibição da sinalização de TGF $\beta$ (JUDSON et al., 2013). Em linha, também é relatado um efeito positivo de miR-302 e miR373 sobre a atividade de WNT/ $\beta$-catenina (GUO et al., 2015; ZHOU et al., 2012a), bem como inibição de TGF $\beta$, neste caso visualizado durante a reprogramação celular induzida por miR302 (SUBRAMANYAM et al., 2011). Adicionalmente a isso, ainda é possível que os 
miRNAs com efeito pró-pluripotência ativem a via TGFß/Activina/Nodal, que, como já apresentado, age como indutor de NANOG e participa assim do estado indiferenciado de células pluripotentes (BARROSO-DEL JESUS; LUCENA-AGUILAR; MENENDEZ, 2009; VALLIER et al., 2009; XU et al., 2008).

Quanto aos clusters fenotípicos de miRNAs que regularam as vias em questão, induzindo a perda das características relacionadas à pluripotência (em NTera-2: A.1 e A.3; em H1: A e B.2), foram identificados como alvos compartilhados entre eles genes para os ligantes WNT e proteínas Frizzled, da via WNT, e receptores de actvina, da via do TGF $\beta$, além de outras proteínas que podem atuar em ambas, como P300 e PCGF3, reguladores da cromatina. Dessa forma, a inibição conjunta de WNT/ $\beta$-catenina e TGF $\beta /$ Activina/Nodal pelos miRNAs destes clusters seria um dos possíveis mecanismos responsáveis por induzir diferenciação em células pluripotentes humanas. Adicionalmente, com a inibição de fatores responsáveis pelo remodelamento da cromatina, estes miRNAs agiriam liberando a rede transcricional de genes relacionados com o comprometimento e destino celular, já que P300 (uma histona acetiltransferase) e PCGF3 (uma proteína do tipo policombo) participam da regulação da estrutura da cromatina em CTE (MOREY; SANTANACH; DI CROCE, 2015; QIAO et al., 2015).

Dentres os miRNAs que compõem esses clusters, o miR-22-3p possui atividade inibitória sobre WNT descrita na literatura, assim como os miRNAs da família do miR-29 (KAUR et al., 2015; LIANG et al., 2016; SUBRAMANIAN et al., 2014; TAN; WU; CAI, 2013; ZHANG et al., 2014), os quais também apresentam inibição da via de TGF $\beta$ (LI et al., 2009). O miR-27a-3p, por sua vez, também é conhecido por inibir a via do TGF $\beta$, agindo sobre a tradução de SMAD2, regulando negativamente a via TGF $\beta /$ Activina/Nodal, inibindo assim o efeito positivo de TGF $\beta$ sobre NANOG, que pode resultar em perda do status de pluripotência em células humanas (CHAE et al., 2017; FUCHS et al., 2014). Esses achados corroboram com o mecanismo proposto anteriormente, relacionando a inativação de $\mathrm{WNT} / \beta$ catenina e TGF $\beta /$ Activina/Nodal com diferenciação nas células pluripotentes. Por outro lado, diferentes trabalhos apresentam a ativação da via WNT por alguns destes miRNAs, como pelos miRs-29, que participa da ativação desta via durante a diferenciação em alguns tipos celulares (KAPINAS et al., 2010; LI et al., 2009; SHIN et al., 2014), e o miR-27a-3p, que inibe antagonistas desta via (CHEN et al., 2017; QIAO et al., 2017; WANG et al., 2015b). Como já apresentado, WNT, apesar de envolvida com a manutenção da pluripotência, também participa da diferenciação celular, portanto estes achados não vão de encontro com o mecanismo previamente proposto, mas sim permitem a hipotetização de um segundo 
mecanismo de indução de diferenciação, onde o acúmulo de $\beta$-catenina levado pela ativação de WNT participaria da expressão de genes envolvidos com o comprometimento celular, função esta já descrita na literatura (DAVIDSON et al., 2012). Levando ainda em consideração o efeito do miR-29b-3p sobre a diferenciação celular de oteoblastos, pode-se supor que a diferenciação induzida por ativação de WNT é acompanhada pela inativação do eixo TGFß/Activina/Nodal-NANOG (LI et al., 2009).

\subsection{Inibição da via Notch por miRNAs promove pluripotência em células-tronco embrionárias e células de carcinoma embrionário humanas}

A sinalização de Notch é uma via conservada que desempenha um papel muito importante no controle do destino celular e no desenvolvimento embrionário em animais, da drosófila ao humano (ARTAVANIS-TSAKONAS; RAND; LAKE, 1999). A ativação desta via se dá pela interação de ligantes, como o DLL1, que interagem com a proteína NOTCH, recrutando assim uma gama-secretase, da qual PSEN1 é uma subunidade. A ação da gamasecretase libera o domínio interno de $\mathrm{NOTCH}$, o qual segue para o núcleo e se complexa com RBPJ, proteína com capacidade de se ligar ao DNA, induzindo assim a expressão de genes efetores da via, como HESI (KAGEYAMA; OHTSUKA; KOBAYASHI, 2007). Em CTEh, a ativação de Notch leva à diferenciação celular, principalmente por ação de HES1, que participa da formação dos diversos tipos celulares devido ao seu comportamento cíclico e oscilativo, resultante de um feedback negativo de HES1 sobre Notch (KOBAYASHI et al., 2009; KOBAYASHI; KAGEYAMA, 2010; YU et al., 2008).

Uma vez conhecendo o papel desta via sobre a diferenciação em células pluripotentes humanas, buscamos então verificar se a inibição de Notch seria um possível mecanismo da promoção de características de pluripotência observada nos clusters fenotípicos. Assim, foram comparados os alvos dos miRNAs aqui estudados com a lista de componentes da via Notch, o que resultou na identificação de três miRNAs com um grande número de alvos na via, sendo eles os miR-302c-3p, miR-92a-3p e o miR-363-3p, com 17, 12 e 12 alvos, respectivamente. Já outros dois miRNAs, os miR-222-3p e miR-371a-3p, que também promoveram pluriotência em NTera-2 e H1, foram identificados com poucos alvos na via (5 e 1 alvos, respectivamente). Nessa linha de raciocínio, decidiu-se verificar a capacidade destes miRNAs de inibirem a diferenciação celular induzida por Notch, sendo que somente o miR-363-3p mostrou-se eficaz em manter uma maior quantidade de OCT4 nuclear nas CCE cocultivadas 
com OP9-DL1, e o mesmo miRNA mostrou-se capaz de causar uma redução significativa nos níveis de transcrito de PSEN1.

É sabido que miRNAs podem regular a via Notch em diferentes situações (BU et al., 2013; ORTEGA et al., 2015; WON et al., 2013), sendo demonstrada a ação repressora do miR-363-3p sobre esta via por meio do bloqueio da produção de NOTCH1 (MENG et al., 2017; SONG et al., 2015), porém o papel dos miRNAs diretamente na regulação de Notch em células pluripotentes ainda não foi explorado e as implicações desta regulação são desconhecidas. Com os dados aqui gerados e em conjunto com o conhecimento existente na literatura, pode-se hipotetizar um mecanismo de regulação da pluripotência por ação do miR363-3p, onde este reprime a ativação da via Notch por knockdown de componentes desta via, como PSEN1 e NOTCH, impedindo assim o efeito indutor de diferenciação desempenhado por HES1 e promovendo autorrenovação e manutenção do status pluripotente. Este mesmo mecanismo pode se aplicar a outros miRNAs ainda não relacionados com Notch em células pluripotentes humanas.

A inibição dos componentes da via Notch pode ainda ser relacionada com uma reprogramação de um estado "primado" para um "naive", já que células neste estado mais indiferenciado não apresentam receptores do tipo NOTCH em suas membranas (COLLIER et al., 2017). Seguindo o mesmo raciocínio, um estudo onde foram avaliadas subpopulações celulares em culturas de CTEh revelou a existência de células com características semelhantes às naive, que embora expressassem OCT4 e NANOG, apresentavam baixa expressão de SSEA4 e TRA-1-81, e eram resistentes à diferenciação induzida por atRA. Nessa população, foi observada uma pequena expressão de componentes da via Notch, enquanto na população com características concordantes com células primadas apresentavam altos níveis destes (ANNAB et al., 2012). Assim, um mecanismo adicional de reprogramação para um estado pluripotente naive regido por miRNAs como o miR-363-3p pode ser proposto. 
6. Conclusões 
No presente trabalho foram estudados os efeitos dos miRNAs sobre o fenótipo pluripotente de células humanas, utilizando uma metodologia recente no campo da ciência no Brasil, a qual se baseia na microscopia automatizada e quantitativa para avaliações a nível celular. O uso dessa abordagem de High Content Analysis (HCA) permitiu a associar modificações fenotípicas celulares com mecanismos moleculares envolvidos na modulação da pluripotência pelos miRNAs. Assim, a realização desta pesquisa trouxe inovação desde à metodologia aplicada aos resultados obtidos, dos quais podemos destacar os seguinte pontos:

- O ensaio desenvolvido permitiu a avaliar quantitativamente o fenótipo das células e gerar perfís fenotípicos multiparamétricos, que levaram a identificação de grupos de miRNAs com efeitos similares e identificação dos transcritos alvos compartilhados entre eles e vias biológicas reguladas;

- O uso de CCE como modelo de pluripotência e relevante para pesquisa em célulastronco, mas não exclui o uso de $\mathrm{CTE}$, sendo os resultados em ambas complementares uma a outra;

- Os efeitos funcionais dos miRNAs sobre a pluripotência, em grande parte, foram concordantes com os dados de transcripitoma, porém os dados discordantes revelam a importância da complementação funcional para estudos moleculares;

- miRNAs podem regular positivamente à pluripotência alvejando proteínas Ago, diminuindo assim a disposição de complexos RISC para miRNAs que inibem os fatores responsáveis pela manutenção do estado indiferenciado de CTEh e CCE;

- A inibição direta das vias PI3K-AKT e mTOR, como também de outras vias que podem levar a indução destas (como a de IGF-1) ocorre por ação de miRNAs que promovem a diferenciação celular por modulação do metabolismo das células pluripotentes;

- miRNAs podem promover características de pluripotência suprimindo inibidores da via PI3K-AKT, como o PTEN;

- O efeito pró-diferenciação de miRNAs que regulam a via TNF, geralmente associada à diferenciação celular, pode se dar por inibição de componentes desta via que levam à ativação de PI3K-AKT ou que participem da manutenção de um estado indiferenciado em células-tronco, como CREB;

- A manutenção do status indiferenciado e promoção de características de pluripotência podem se dar pelo efeito inibidor de miRNAs sobre a via dos TLR, por supressão de MEK6 e consequente inibição da atividade de P38; 
- A modulação das vias WNT e TGF $\beta$ pode se dar por miRNAs que promovem a pluripotência ao inibir o efeito indutor de diferenciação dessas vias, como a atividade de FZD4 e das BMPs. Em contrapartida, miRNAs que induzem a diferenciação podem reprimir as vias WNT/ $\beta$-catenina e TGF $\beta /$ Activina/Nodal alvejando ligantes e receptores de WNT ou de activina;

- miRNAs com ação indutora de diferenciação podem suprimir de P300 e PCGF3, liberando redes de transcricionais ligadas ao comprometimento celular;

- A inibição de Notch por miRNAs leva à promoção de características de pluripotência e pode estar relacionada com a reprogramação para um estado pluripotente naive em CTEh. A atividade pró-pluripotência do miR-363-3p está relacionada com a repressão sobre PSEN1, consequentement, da sinalização de Notch. 
7. REFERÊNCIAS BIBLIOGRÁFICAS 
ABERLE, $\mathrm{H}$. et al. beta-catenin is a target for the ubiquitin-proteasome pathway. The EMBO journal, v. 16, n. 13, p. 3797-804, 1 jul. 1997.

ACHARD, P. et al. Modulation of floral development by a gibberellin-regulated microRNA. Development (Cambridge, England), v. 131, n. 14, p. 3357-65, 2004.

ALVA, J. A. et al. Phosphatase and tensin homolog regulates the pluripotent state and lineage fate choice in human embryonic stem cells. Stem cells (Dayton, Ohio), v. 29, n. 12, p. 195262, dez. 2011.

AMBROS, V. A hierarchy of regulatory genes controls a larva-to-adult developmental switch in C. elegans. Cell, v. 57, n. 1, p. 49-57, 1989.

AMBROS, V.; HORVITZ, H. R. Heterochronic mutants of the nematode Caenorhabditis elegans. Science (New York, N.Y.), v. 226, n. 4673, p. 409-16, 1984.

AMBROS, V.; HORVITZ, H. R. The lin-14 locus of Caenorhabditis elegans controls the time of expression of specific postembryonic developmental events. Genes \& development, v. 1, n. 4, p. 398-414, 1987.

AMIT, M. et al. Clonally Derived Human Embryonic Stem Cell Lines Maintain Pluripotency and Proliferative Potential for Prolonged Periods of Culture. Developmental Biology, v. 227, n. 2, p. 271-278, 2000.

ANDREWS, P. W. et al. Cell-surface antigens of a clonal human embryonal carcinoma cell line: morphological and antigenic differentiation in culture. International journal of cancer, v. 29, n. 5, p. 523-31, 15 maio 1982.

ANDREWS, P. W. et al. Two monoclonal antibodies recognizing determinants on human embryonal carcinoma cells react specifically with the liver isozyme of human alkaline phosphatase. Hybridoma, v. 3, n. 1, p. 33-9, jan. 1984a.

ANDREWS, P. W. et al. Three monoclonal antibodies defining distinct differentiation antigens associated with different high molecular weight polypeptides on the surface of human embryonal carcinoma cells. Hybridoma, v. 3, n. 4, p. 347-61, jan. 1984 b.

ANDREWS, P. W. Retinoic acid induces neuronal differentiation of a cloned human embryonal carcinoma cell line in vitro. Developmental biology, v. 103, n. 2, p. 285-93, jun. 1984.

ANDREWS, P. W. From teratocarcinomas to embryonic stem cells. Philosophical transactions of the Royal Society of London. Series B, Biological sciences, v. 357, n. 1420, p. 405-17, 29 abr. 2002.

ANNAB, L. A. et al. Differential responses to retinoic acid and endocrine disruptor compounds of subpopulations within human embryonic stem cell lines. Differentiation; research in biological diversity, v. 84, n. 4, p. 330-43, nov. 2012.

ANNES, J. P.; MUNGER, J. S.; RIFKIN, D. B. Making sense of latent TGFbeta activation. Journal of cell science, v. 116, n. Pt 2, p. 217-24, 15 jan. 2003. 
ANOKYE-DANSO, F. et al. Highly efficient miRNA-mediated reprogramming of mouse and human somatic cells to pluripotency. Cell stem cell, v. 8, n. 4, p. 376-88, 8 abr. 2011.

ANTON, R. et al. $\beta$-Catenin signaling contributes to stemness and regulates early differentiation in murine embryonic stem cells. FEBS Letters, v. 581, n. 27, p. 5247-5254, 2007.

ANTOON, J. W. et al. Inhibition of p38 mitogen-activated protein kinase alters microRNA expression and reverses epithelial-to-mesenchymal transition. International Journal of Oncology, v. 42, n. 4, p. 1139-1150, 2013.

ARMSTRONG, L. et al. The role of PI3K/AKT, MAPK/ERK and NFkappabeta signalling in the maintenance of human embryonic stem cell pluripotency and viability highlighted by transcriptional profiling and functional analysis. Human molecular genetics, v. 15, n. 11, p. 1894-913, 1 jun. 2006.

ARTAVANIS-TSAKONAS, S.; RAND, M. D.; LAKE, R. J. Notch signaling: cell fate control and signal integration in development. Science (New York, N.Y.), v. 284, n. 5415, p. 770-6, 30 abr. 1999.

AVILION, A. A. et al. Multipotent cell lineages in early mouse development on SOX2 function. Genes Dev., v. 17, n. 1, p. 126-140, 1 jan. 2003.

BADCOCK, G. et al. The human embryonal carcinoma marker antigen TRA-1-60 is a sialylated keratan sulfate proteoglycan. Cancer research, v. 59, n. 18, p. 4715-9, 15 set. 1999.

BAI, L. et al. MicroRNA-21 Regulates PI3K/Akt/mTOR Signaling by Targeting TGF $\beta$ I during Skeletal Muscle Development in Pigs. PloS one, v. 10, n. 5, p. e0119396, 2015.

BAKRE, M. M. et al. Generation of multipotential mesendodermal progenitors from mouse embryonic stem cells via sustained Wnt pathway activation. Journal of Biological Chemistry, v. 282, n. 43, p. 31703-31712, 2007.

BARBARIC, I.; HARRISON, N. J. Rediscovering pluripotency: from teratocarcinomas to embryonic stem cells. Cardiff, 10-12 October 2011. The International journal of developmental biology, v. 56, n. 4, p. 197-206, jan. 2012.

BARROSO-DEL JESUS, A.; LUCENA-AGUILAR, G.; MENENDEZ, P. The miR-302-367 cluster as a potential stemness regulator in ESCs. Cell Cycle, v. 8, n. 3, p. 394-398, 2009.

BARRUET, E. et al. P38 Mitogen Activated Protein Kinase Controls Two Successive-Steps During the Early Mesodermal Commitment of Embryonic Stem Cells. Stem cells and development, v. 20, n. 7, p. 1233-46, 2011.

BARTA, T. et al. Inhibition of miR-145 Enhances Reprogramming of Human Dermal Fibroblasts to Induced Pluripotent Stem Cells. Stem Cells, v. 34, p. 246-251, 2016.

BARTEL, D. P.; LEE, R.; FEINBAUM, R. MicroRNAs: Genomics , Biogenesis , Mechanism, and Function Genomics : The miRNA Genes. v. 116, p. 281-297, 2004. 
BEHR, B. et al. Stem cells. Plastic and reconstructive surgery, v. 126, n. 4, p. 1163-71, out. 2010.

BERARDI, E. et al. miRNAs in ESC differentiation. American journal of physiology. Heart and circulatory physiology, v. 303, n. 8, p. H931-9, 15 out. 2012.

BERGE, D. et al. Embryonic stem cells require Wnt proteins to prevent differentiation to epiblast stem cells. Nature cell biology, v. 13, n. 9, p. 1070-5, 14 ago. 2011.

BETSCHINGER, J. et al. Exit from pluripotency is gated by intracellular redistribution of the bHLH transcription factor Tfe3. Cell, v. 153, n. 2, p. 335-47, 11 abr. 2013.

BICKLE, M. The beautiful cell: High-content screening in drug discovery. Analytical and Bioanalytical Chemistry, v. 398, n. 1, p. 219-226, 2010.

BINÉTRUY, B. et al. Concise Review: Regulation of Embryonic Stem Cell Lineage Commitment by Mitogen-Activated Protein Kinases. Stem Cells, v. 25, n. 5, p. 1090-1095, 2007.

BITTEL, D. C. et al. MicroRNA-421 Dysregulation is Associated with Tetralogy of Fallot. Cells, v. 3, n. 3, p. 713-23, 2014.

BLAU, H. M.; CHIU, C. P.; WEBSTER, C. Cytoplasmic activation of human nuclear genes in stable heterocaryons. Cell, v. 32, n. 4, p. 1171-80, abr. 1983.

BLECKMANN, S. C. et al. Activating transcription factor 1 and CREB are important for cell survival during early mouse development. Molecular and cellular biology, v. 22, n. 6, p. 1919-25, mar. 2002.

BLELLOCH, R. H. et al. Nuclear cloning of embryonal carcinoma cells. Proc Natl Acad Sci U S A, v. 101, n. 39, p. 13985-13990, 2004.

BORCHERT, G. M.; LANIER, W.; DAVIDSON, B. L. RNA polymerase III transcribes human microRNAs. Nature Structural \& Molecular Biology, v. 13, n. 12, p. 1097-1101, 2006.

BORNACHEA, O. et al. EMT and induction of miR-21 mediate metastasis development in Trp53-deficient tumours. Scientific Reports, v. 2, p. 1-12, 2012.

BOUTROS, M.; HEIGWER, F.; LAUFER, C. Microscopy-Based High-Content Screening. Cell, v. 163, n. 6, p. 1314-1325, 2015.

BRIGGS, R.; KING, T. J. Transplantation of Living Nuclei From Blastula Cells into Enucleated Frogs' Eggs. Proceedings of the National Academy of Sciences of the United States of America, v. 38, n. 5, p. 455-63, maio 1952.

BU, P. et al. A microRNA miR-34a-regulated bimodal switch targets Notch in colon cancer stem cells. Cell stem cell, v. 12, n. 5, p. 602-15, 2 maio 2013.

BUENO, M. J.; MALUMBRES, M. MicroRNAs and the cell cycle. Biochimica et 
Biophysica Acta - Molecular Basis of Disease, v. 1812, n. 5, p. 592-601, 2011.

CARD, D. A G. et al. Oct4/Sox2-regulated miR-302 targets cyclin D1 in human embryonic stem cells. Molecular and cellular biology, v. 28, n. 20, p. 6426-38, out. 2008.

CARDINALLI, B. et al. Microrna-221 and microrna-222 modulate differentiation and maturation of skeletal muscle cells. PLoS ONE, v. 4, n. 10, 2009.

CARÈ, A. et al. MicroRNA-133 controls cardiac hypertrophy. Nature medicine, v. 13, n. 5, p. 613-8, 2007.

CARLETON, M.; CLEARY, M. A.; LINSLEY, P. S. MicroRNAs and cell cycle regulation. Cell Cycle, v. 6, n. 17, p. 2127-2132, 2007.

CHAE, D.-K. et al. MIR-27a regulates the TGF- $\beta$ signaling pathway by targeting SMAD2 and SMAD4 in lung cancer. Molecular carcinogenesis, n. December 2016, 31 mar. 2017.

CHAERKADY, R. et al. Comparative proteomics of human embryonic stem cells and embryonal carcinoma cells. Proteomics, v. 10, n. 7, p. 1359-73, abr. 2010.

CHALFIE, M.; HORVITZ, H. R.; SULSTON, J. E. Mutations that lead to reiterations in the cell lineages of C. elegans. Cell, v. 24, n. 1, p. 59-69, abr. 1981.

CHAMBERS, I. et al. Functional expression cloning of Nanog, a pluripotency sustaining factor in embryonic stem cells. Cell, v. 113, n. 5, p. 643-55, 30 maio 2003.

CHAMBERS, I. et al. Nanog safeguards pluripotency and mediates germline development. Nature, v. 450, n. 7173, p. 1230-1234, 20 dez. 2007.

CHAMBERS, I.; TOMLINSON, S. R. The transcriptional foundation of pluripotency. Development (Cambridge, England), v. 136, n. 14, p. 2311-22, jul. 2009.

CHEN, C.-Z. MicroRNAs Modulate Hematopoietic Lineage Differentiation. Science, v. 303, n. 5654, p. 83-86, 2004.

CHEN, J. et al. Synergetic cooperation of microRNAs with transcription factors in iPS cell generation. PloS one, v. 7, n. 7, p. e40849, 2012a.

CHEN, M. et al. Promotion of the induction of cell pluripotency through metabolic remodeling by thyroid hormone triiodothyronine-activated PI3K/AKT signal pathway. Biomaterials, v. 33, n. 22, p. 5514-5523, 2012 b.

CHEN, S. et al. Transcriptional suppression of microRNA-27a contributes to laryngeal cancer differentiation via GSK-3 $\beta$-involved Wnt/ $\beta$-catenin pathway. Oncotarget, v. 8, n. 9, p. 14708-14718, 28 fev. 2017.

CHENG, S.-C. et al. mTOR- and HIF-1 $\alpha$-mediated aerobic glycolysis as metabolic basis for trained immunity. Science (New York, N.Y.), v. 345, n. 6204, p. 1250684, 26 set. 2014.

CHEW, J. et al. Reciprocal Transcriptional Regulation of Complex in Embryonic Stem Cells 
Reciprocal Transcriptional Regulation of Pou5f1 and Sox2 via the Oct4 / Sox 2 Complex in Embryonic Stem Cells. Molecular and Cellular Biology, v. 25, n. 14, p. 6031-6046, 2006.

CHUANG, C. F.; BARGMANN, C. I. A Toll-interleukin 1 repeat protein at the synapse specifies asymmetric odorant receptor expression via ASK1 MAPKKK signaling. Genes and Development, v. 19, n. 2, p. 270-281, 2005.

CHUN-ZHI, Z. et al. MicroRNA-221 and microRNA-222 regulate gastric carcinoma cell proliferation and radioresistance by targeting PTEN. BMC Cancer, v. 10, p. 367, 2010.

CHUN, Y. S.; CHAUDHARI, P.; JANG, Y.-Y. Applications of patient-specific induced pluripotent stem cells; focused on disease modeling, drug screening and therapeutic potentials for liver disease. International journal of biological sciences, v. 6, n. 7, p. 796-805, 14 dez. 2010 .

CICCHINI, C. et al. Epigenetic control of EMT/MET dynamics: HNF4 $\alpha$ impacts DNMT3s through miRs-29. Biochimica et Biophysica Acta - Gene Regulatory Mechanisms, v. 1849, n. 8, p. 919-929, 2015.

COLliER, A. J. et al. Comprehensive Cell Surface Protein Profiling Identifies Specific Markers of Human Naive and Primed Pluripotent States. Cell stem cell, v. 20, n. 6, p. 874890.e7, 1 jun. 2017.

COSKUN, E.; ERCIN, M.; GEZGINCI-OKTAYOGLU, S. The Role of Epigenetic Regulation and Pluripotency-Related MicroRNas in Differentiation of Pancreatic Stem Cells to Beta Cells. Journal of cellular biochemistry, n. June, 9 jun. 2017.

CUI, Y. et al. miR-29 regulates Tet1 expression and contributes to early differentiation of mouse ESCs. Oncotarget, v. 7, n. 40, p. 64932-64941, 4 out. 2016.

DAVIDSON, K. C. et al. Wnt/ $\beta$-catenin signaling promotes differentiation, not self-renewal, of human embryonic stem cells and is repressed by Oct4. Proceedings of the National Academy of Sciences of the United States of America, v. 109, n. 12, p. 4485-90, 20 mar. 2012.

DAVIDSON, S. M.; MORANGE, M. Hsp25 and the p38 MAPK Pathway Are Involved in Differentiation of Cardiomyocytes. Developmental Biology, v. 218, n. 2, p. 146-160, 2000.

DAVIS, R. L.; WEINTRAUB, H.; LASSAR, A. B. Expression of a single transfected cDNA converts fibroblasts to myoblasts. Cell, v. 51, n. 6, p. 987-1000, 24 dez. 1987.

DE CRAENE, B.; BERX, G. Regulatory networks defining EMT during cancer initiation and progression. Nature reviews. Cancer, v. 13, n. 2, p. 97-110, fev. 2013.

DE MIGUEL, M. P.; FUENTES-JULIÁN, S.; ALCAINA, Y. Pluripotent stem cells: origin, maintenance and induction. Stem cell reviews, v. 6, n. 4, p. 633-49, dez. 2010.

DORMEYER, W. et al. Plasma membrane proteomics of human embryonic stem cells and human embryonal carcinoma cells. J Proteome Res, v. 7, n. 7, p. 2936-2951, 2008. 
DRAPER, J. S. et al. Surface antigens of human embryonic stem cells: changes upon differentiation in culture. Journal of anatomy, v. 200, n. Pt 3, p. 249-58, mar. 2002.

DUPONT, C.; ARMANT, D. R.; BRENNER, C. A. Epigenetics: definition, mechanisms and clinical perspective. Seminars in reproductive medicine, v. 27, n. 5, p. 351-7, 9 set. 2009.

EASTHAM, A. M. et al. Epithelial-mesenchymal transition events during human embryonic stem cell differentiation. Cancer research, v. 67, n. 23, p. 11254-62, 1 dez. 2007.

EISENBERG, I. et al. Distinctive patterns of microRNA expression in primary muscular disorders. Proceedings of the National Academy of Sciences of the United States of America, v. 104, n. 43, p. 17016-21, 23 out. 2007.

ENDO, K.; HAYASHI, K.; SAITO, H. High-resolution Identification and Separation of Living Cell Types by Multiple microRNA-responsive Synthetic mRNAs. Scientific reports, v. 6, n. November 2015, p. 21991, 2016.

EULALIO, A. et al. Functional screening identifies miRNAs inducing cardiac regeneration. Nature, v. 492, n. 7429, p. 376-381, 2012.

FABIAN, M. R.; SONENBERG, N.; FILIPOWICZ, W. Regulation of mRNA translation and stability by microRNAs. Annual review of biochemistry, v. 79, p. 351-379, 2010.

FIDALGO, M. et al. Zfp281 mediates Nanog autorepression through recruitment of the NuRD complex and inhibits somatic cell reprogramming. Proceedings of the National Academy of Sciences, v. 109, n. 40, p. 16202-16207, 2012.

FILIPOWICZ, W.; BHATTACHARYYA, S. N.; SONENBERG, N. Mechanisms of posttranscriptional regulation by microRNAs: are the answers in sight? Nat Rev Genet, v. 9, n. 2, p. 102-114, 2008.

FINCH, B. W.; EPHRUSSI, B. RETENTION OF MULTIPLE DEVELOPMENTAL POTENTIALITIES BY CELLS OF A MOUSE TESTICULAR TERATOCARCINOMA DURING PROLONGED CULTURE in vitro AND THEIR EXTINCTION UPON HYBRIDIZATION WITH CELLS OF PERMANENT LINES. Proceedings of the National Academy of Sciences of the United States of America, v. 57, n. 3, p. 615-21, mar. 1967.

FRÁGUAS, M. S. et al. MicroRNA-29 impairs the early phase of reprogramming process by targeting active DNA demethylation enzymes and Wnt signaling. Stem Cell Research, v. 19, p. 21-30, 2017.

FRIEDMAN, R. C. et al. Most mammalian mRNAs are conserved targets of microRNAs. Genome Research, v. 19, n. 1, p. 92-105, jan. 2009.

FUCHS, H. et al. miR-27 negatively regulates pluripotency-associated genes in human embryonal carcinoma cells. PloS one, v. 9, n. 11, p. e111637, 2014.

FUSCO, S. et al. A CREB-Sirt1-Hes1 Circuitry Mediates Neural Stem Cell Response to Glucose Availability. Cell Reports, v. 14, n. 5, p. 1195-1205, 2016. 
GALLAGHER, M. F. et al. Regulation of microRNA biosynthesis and expression in 2102Ep embryonal carcinoma stem cells is mirrored in ovarian serous adenocarcinoma patients. Journal of Ovarian Research, v. 2, n. 1, p. 19, 2009.

GALVÁN, J. A. et al. Expression of E-cadherin repressors SNAIL, ZEB1 and ZEB2 by tumour and stromal cells influences tumour-budding phenotype and suggests heterogeneity of stromal cells in pancreatic cancer. British journal of cancer, v. 112, n. 12, p. 1944-50, 9 jun. 2015 .

GASPAR-MAIA, A. et al. Open chromatin in pluripotency and reprogramming. Nature Reviews Molecular Cell Biology, v. 12, n. 1, p. 36-47, jan. 2011.

GONZALEZ-MORENO, O. et al. VEGF elicits epithelial-mesenchymal transition (EMT) in prostate intraepithelial neoplasia (PIN)-like cells via an autocrine loop. Experimental Cell Research, v. 316, n. 4, p. 554-567, 2010.

GORETSKY, T. et al. P53 mediates TNF-induced epithelial cell apoptosis in IBD. American Journal of Pathology, v. 181, n. 4, p. 1306-1315, 2012.

GREBER, B.; LEHRACH, H.; ADJAYE, J. Silencing of core transcription factors in human EC cells highlights the importance of autocrine FGF signaling for self-renewal. v. 15, p. 1-15, 2007.

GRISHOK, A. et al. Genes and mechanisms related to RNA interference regulate expression of the small temporal RNAs that control C. elegans developmental timing. Cell, v. 106, n. 1, p. 23-34, 2001.

GU, K.-L. et al. Pluripotency-associated miR-290/302 family of microRNAs promote the dismantling of naive pluripotency. Cell Research, v. 26, n. 3, p. 350-366, 2016.

GUO, W.-T. et al. Suppression of epithelial-mesenchymal transition and apoptotic pathways by miR-294/302 family synergistically blocks let-7-induced silencing of self-renewal in embryonic stem cells. Cell Death and Differentiation, v. 22, n. 7, p. 1158-1169, 2015.

GURDON, J. B. The developmental capacity of nuclei taken from intestinal epithelium cells of feeding tadpoles. Journal of embryology and experimental morphology, v. 10, n. December, p. 622-40, dez. 1962.

HADJAL, Y. et al. A p38mapk-p53 cascade regulates mesodermal differentiation and neurogenesis of embryonic stem cells. Cell Death and Disease, v. 4, n. 7, p. e737, 2013.

HAMILTON, W. B.; BRICKMAN, J. M. Erk Signaling Suppresses Embryonic Stem Cell Self-Renewal to Specify Endoderm. Cell Reports, v. 9, n. 6, p. 2056-2070, 2014.

HAN, J. et al. The Drosha - DGCR8 complex in primary microRNA processing. Genes \& Development, p. 3016-3027, 2004.

HAND, N. J. et al. MicroRNA profiling identifies miR-29 as a regulator of disease-associated pathways in experimental biliary atresia. Journal of pediatric gastroenterology and nutrition, v. 54, n. 2, p. 186-92, fev. 2012. 
HAUSSER, J. et al. Relative contribution of sequence and structure features to the mRNA binding of Argonaute/EIF2C-miRNA complexes and the degradation of miRNA targets. Genome research, v. 19, n. 11, p. 2009-20, nov. 2009.

HAY, E. D. An overview of epithelio-mesenchymal transformation. Acta anatomica, v. 154, n. 1, p. 8-20, jan. 1995.

HAYES, J.; PERUZZI, P. P.; LAWLER, S. MicroRNAs in cancer: biomarkers, functions and therapy. Trends in molecular medicine, v. 20, n. 8, p. 460-9, ago. 2014.

HE, R. et al. Comprehensive investigation of aberrant microRNAs expression in cells culture model of $\mathrm{MnCl} 2$-induced neurodegenerative disease. Biochemical and biophysical research communications, v. 486, n. 2, p. 342-348, 29 abr. 2017.

HE, S. et al. Lymphoid Enhancer Factor 1-Mediated Wnt Signaling Promotes the Initiation of Trophoblast Lineage Differentiation in Mouse Embryonic Stem Cells. Stem Cells, v. 26, n. 4, p. 842-849, 2008.

HÉBERT, S. S.; DE STROOPER, B. Alterations of the microRNA network cause neurodegenerative disease. Trends in Neurosciences, v. 32, n. 4, p. 199-206, 2009.

HENAO-MEJIA, J. et al. The microRNA miR-181 is a critical cellular metabolic rheostat essential for NKT cell ontogenesis and lymphocyte development and homeostasis. Immunity, v. 38, n. 5, p. 984-97, 23 maio 2013.

HENDRICKSON, D. G. et al. Concordant regulation of translation and mRNA abundance for hundreds of targets of a human microRNA. PLoS Biology, v. 7, n. 11, p. 25-29, 2009.

HONG, L. et al. The miR-17-92 cluster of microRNAs confers tumorigenicity by inhibiting oncogene-induced senescence. Cancer Research, v. 70, n. 21, p. 8547-8557, 2010.

HOSSINI, A. M. et al. PI3K/AKT signaling pathway is essential for survival of induced pluripotent stem cells. PLoS ONE, v. 11, n. 5, p. 1-27, 2016.

HOUBAVIY, H. B.; MURRAY, M. F.; SHARP, P. A. Embryonic stem cell-specific MicroRNAs. Developmental cell, v. 5, n. 2, p. 351-358, 2003.

HUA, Y. et al. miRConnect: identifying effector genes of miRNAs and miRNA families in cancer cells. PloS one, v. 6, n. 10, p. e26521, jan. 2011.

HUANG, Y.-H. et al. Pluripotency of mouse spermatogonial stem cells maintained by IGF-1dependent pathway. The FASEB Journal, v. 23, n. 7, p. 2076-2087, 2009.

HUMPHREY, R. K. et al. Maintenance of pluripotency in human embryonic stem cells is STAT3 independent. Stem cells (Dayton, Ohio), v. 22, n. 4, p. 522-30, jan. 2004.

HUTVÁGNER, G. et al. A cellular function for the RNA-interference enzyme Dicer in the maturation of the let-7 small temporal RNA. Science (New York, N.Y.), v. 293, n. 5531, p. 834-838, 2001. 
IVEY, K. N.; SRIVASTAVA, D. MicroRNAs as regulators of differentiation and cell fate decisions. Cell Stem Cell, v. 7, n. 1, p. 36-41, 2010.

JEE, J. et al. High Content Screening for Compounds that Induce Early Stages of Human Embryonic Stem Cell DifferentiationCombinatorial Chemistry \& High Throughput Screening, 2012.

JERABEK, S. et al. OCT4: Dynamic DNA binding pioneers stem cell pluripotency. Biochimica et Biophysica Acta - Gene Regulatory Mechanisms, v. 1839, n. 3, p. 138-154, 2014.

JIA, L. et al. Androgen receptor-regulated miRNA-193a-3p targets AJUBA to promote prostate cancer cell migration. The Prostate, n. January, 19 abr. 2017.

JIANG, W. et al. MicroRNA-Related Polymorphisms in PI3K/Akt/mTOR Pathway Genes Are Predictive of Limited-Disease Small Cell Lung Cancer Treatment Outcomes. BioMed research international, v. 2017, p. 6501385, 2017.

JIANG, X. et al. miR-22 has a potent anti-tumour role with therapeutic potential in acute myeloid leukaemia. Nature communications, v. 7, n. 7, p. 11452, 26 abr. 2016.

JOSSE, C. et al. Identification of a microRNA landscape targeting the PI3K/Akt signaling pathway in inflammation-induced colorectal carcinogenesis. American journal of physiology. Gastrointestinal and liver physiology, v. 306, n. 3, p. G229-43, fev. 2014.

JUDSON, R. L. et al. MicroRNA-based discovery of barriers to dedifferentiation of fibroblasts to pluripotent stem cells. Nature structural \& molecular biology, v. 20, n. 10, p. 1227-35, out. 2013.

KAGEYAMA, R.; OHTSUKA, T.; KOBAYASHI, T. The Hes gene family: repressors and oscillators that orchestrate embryogenesis. Development, v. 134, n. 7, p. 1243-1251, 2007.

KAHAN, B. W.; EPHRUSSI, B. Developmental potentialities of clonal in vitro cultures of mouse testicular teratoma.Journal of the National Cancer Institute, maio 1970. Disponível em: <http://www.ncbi.nlm.nih.gov/pubmed/5514468>

KANELLOPOULOU, C. et al. Dicer-deficient mouse embryonic stem cells are defective in differentiation and centromeric silencing. Genes and Development, v. 19, n. 4, p. 489-501, 2005 .

KAPINAS, K. et al. miR-29 modulates Wnt signaling in human osteoblasts through a positive feedback loop. The Journal of biological chemistry, v. 285, n. 33, p. 25221-31, 13 ago. 2010 .

KASSCHAU, K. D. et al. P1/HC-Pro, a viral suppressor of RNA silencing, interferes with Arabidopsis development and miRNA unction. Developmental cell, v. 4, n. 2, p. 205-17, fev. 2003.

KAUFMANN, L. T.; NIEHRS, C. Gadd45a and Gadd45g regulate neural development and exit from pluripotency in Xenopus. Mechanisms of Development, v. 128, n. 7-10, p. 401- 
$411,2011$.

KAUR, K. et al. Elevated Hepatic miR-22-3p Expression Impairs Gluconeogenesis by Silencing the Wnt-Responsive Transcription Factor Tcf7. Diabetes, v. 64, n. 11, p. 3659-69, nov. 2015.

KELLY, K. F. et al. $\beta$-catenin enhances Oct-4 activity and reinforces pluripotency through a TCF-independent mechanism. Cell Stem Cell, v. 8, n. 2, p. 214-227, 2011.

KIM, J. et al. HIF-1-mediated expression of pyruvate dehydrogenase kinase: a metabolic switch required for cellular adaptation to hypoxia. Cell metabolism, v. 3, n. 3, p. 177-85, mar. 2006.

KIM, J. et al. A MicroRNA Feedback Circuit in Midbrain Dopamine Neurons. Science, v. 317, n. 5842, p. 1220-1224, 31 ago. 2007.

KIM, J. et al. miR-221 regulates CD44 in hepatocellular carcinoma through the PI3K-AKTmTOR pathway. Biochemical and biophysical research communications, p. 1-7, 22 abr. 2017.

KOBAYASHI, T. et al. The cyclic gene Hes 1 contributes to diverse differentiation responses of embryonic stem cells. Genes and Development, v. 23, n. 16, p. 1870-1875, 2009.

KOBAYASHI, T.; KAGEYAMA, R. Hes1 regulates embryonic stem cell differentiation by suppressing Notch signaling. Genes to Cells, v. 15, n. 7, p. 689-698, 2010.

KOLIOS, G.; MOODLEY, Y. Introduction to stem cells and regenerative medicine. Respiration; international review of thoracic diseases, v. 85, n. 1, p. 3-10, jan. 2013.

KUNATH, T.; STRUMPF, D.; ROSSANT, J. Early trophoblast determination and stem cell maintenance in the mouse--a review. Placenta, v. 25 Suppl A, p. S32-8, 2004.

LAGOS-QUINTANA, M. et al. Identification of novel genes Coding for RNAs of Small expressed RNAs. Science, v. 294, n. 5543, p. 853-858, 2001.

LAI, L. et al. MicroRNA-92a negatively regulates toll-like receptor (TLR)-triggered inflammatory response in macrophages by targeting MKK4 kinase. Journal of Biological Chemistry, v. 288, n. 11, p. 7956-7967, 2013.

LAJTHA, L. G. Views Stem Cell Concepts. Differentiation, v. 14, p. 23-33, 1979.

LAKSHMIPATHY, U. et al. MicroRNA expression pattern of undifferentiated and differentiated human embryonic stem cells. Stem cells and development, v. 16, n. 6, p. 1003-16, dez. 2007.

LAKSHMIPATHY, U.; DAVILA, J.; HART, R. P. miRNA in pluripotent stem cells. Regenerative medicine, v. 5, n. 4, p. 545-55, jul. 2010.

LAMOUILLE, S.; XU, J.; DERYNCK, R. Molecular mechanisms of epithelial-mesenchymal transition. Nature reviews. Molecular cell biology, v. 15, n. 3, p. 178-96, mar. 2014. 
LAURENT, L. C. et al. Comprehensive microRNA profiling reveals a unique human embryonic stem cell signature dominated by a single seed sequence. Stem cells (Dayton, Ohio), v. 26, n. 6, p. 1506-16, jun. 2008.

LEE, R. C.; FEINBAUM, R. L.; AMBROS, V. The C. elegans heterochronic gene lin-4 encodes small RNAs with antisense complementarity to lin-14. Cell, v. 75, n. 5, p. 843-854, 1993.

LEE, Y. et al. MicroRNA genes are transcribed by RNA polymerase II. Embo J, v. 23, n. 20, p. 4051-4060, 2004.

LEUNG, A. W.; KENT MOREST, D.; LI, J. Y. H. Differential BMP signaling controls formation and differentiation of multipotent preplacodal ectoderm progenitors from human embryonic stem cells. Developmental biology, v. 379, n. 2, p. 208-20, 15 jul. 2013.

LI, C.; ZHANG, P.; GU, J. miR-29a modulates tumor necrosis factor- $\alpha$-induced osteogenic inhibition by targeting Wnt antagonists. Development Growth and Differentiation, v. 57, n. 3, p. 264-273, 2015.

LI, F. et al. Apoptotic caspases regulate induction of iPSCs from human fibroblasts. Cell stem cell, v. 7, n. 4, p. 508-20, 8 out. 2010.

LI, Y. et al. BMP4-directed trophoblast differentiation of human embryonic stem cells is mediated through a $\Delta \mathrm{Np}{ }^{+}$cytotrophoblast stem cell state. Development, v. 140, n. 19, p. 3965-3976, 2013.

LI, Z. et al. Biological functions of miR-29b contribute to positive regulation of osteoblast differentiation. The Journal of biological chemistry, v. 284, n. 23, p. 15676-84, 5 jun. 2009.

LIANG, J. et al. Nanog and Oct4 associate with unique transcriptional repression complexes in embryonic stem cells. Nature cell biology, v. 10, n. 6, p. 731-9, jun. 2008.

LIANG, W.-C. et al. H19 activates Wnt signaling and promotes osteoblast differentiation by functioning as a competing endogenous RNA. Scientific reports, v. 6, n. 1, p. 20121, 8 fev. 2016.

LICHNER, Z. et al. The miR-290-295 cluster promotes pluripotency maintenance by regulating cell cycle phase distribution in mouse embryonic stem cells. Differentiation; research in biological diversity, v. 81, n. 1, p. 11-24, jan. 2011.

LIM, L. P. et al. Microarray analysis shows that some microRNAs downregulate large numbers of target mRNAs. Nature, v. 433, n. 7027, p. 769-73, 17 fev. 2005.

LIM, L. S. et al. The pluripotency regulator Zic3 is a direct activator of the Nanog promoter in ESCs. Stem cells (Dayton, Ohio), v. 28, n. 11, p. 1961-9, nov. 2010.

LINDSLEY, R. C. et al. Canonical Wnt signaling is required for development of embryonic stem cell-derived mesoderm. Development (Cambridge, England), v. 133, n. 19, p. 378796, out. 2006. 
LIU, G. et al. MiR-27a regulates apoptosis in nucleus pulposus cells by targeting PI3K. PloS one, v. 8, n. 9, p. e75251, 2013.

LIU, Y. et al. Genome wide profiling of human embryonic stem cells (hESCs), their derivatives and embryonal carcinoma cells to develop base profiles of U.S. Federal government approved hESC lines. BMC Dev Biol, v. 6, p. 20, 2006.

LIU, Z. et al. MicroRNA-21 regulates biological behavior by inducing EMT in human cholangiocarcinoma. International Journal of Clinical and Experimental Pathology, v. 8, n. 5, p. 4684-4694, 2015.

LOCKSLEY, R. M.; KILLEEN, N.; LENARDO, M. J. The TNF and TNF receptor superfamilies: Integrating mammalian biology. Cell, v. 104, n. 4, p. 487-501, 2001.

LOH, Y. et al. The Oct4 and Nanog transcription network regulates pluripotency in mouse embryonic stem cells. Nature Genetics, v. 38, n. 4, p. 431-440, abr. 2006.

LOVE, M. S. et al. A high-throughput phenotypic screen identifies clofazimine as a potential treatment for cryptosporidiosis. PLoS Neglected Tropical Diseases, v. 11, n. 2, p. 1-19, 2017.

LÜNINGSCHRÖR, P. et al. MicroRNAs in pluripotency, reprogramming and cell fate induction. Biochimica et Biophysica Acta - Molecular Cell Research, v. 1833, n. 8, p. 1894-1903, 2013.

LYASHENKO, N. et al. Differential requirement for the dual functions of $\beta$-catenin in embryonic stem cell self-renewal and germ layer formation. Nature cell biology, v. 13, n. 7, p. 753-61, 19 jun. 2011.

MA, Y. et al. Functional screen reveals essential roles of miR-27a/24 in differentiation of embryonic stem cells. The EMBO journal, v. 34, n. 3, p. 361-78, 3 fev. 2015.

MAHERALI, N.; HOCHEDLINGER, K. Tgfbeta signal inhibition cooperates in the induction of iPSCs and replaces Sox 2 and cMyc. Current biology : CB, v. 19, n. 20, p. 1718-23, 3 nov. 2009.

MALLICK, B.; CHAKRABARTI, J.; GHOSH, Z. MicroRNA reins in embryonic and cancer stem cells. RNA biology, v. 8, n. 3, p. 415-26, 1 maio 2011.

MANNING, A. J. et al. A high content microscopy assay to determine drug activity against intracellular Mycobacterium tuberculosis. Methods (San Diego, Calif.), 31 mar. 2017.

MARSON, A. et al. Connecting microRNA Genes to the Core Transcriptional Regulatory Circuitry of Embryonic Stem Cells. Cell, v. 134, n. 3, p. 521-533, 2008a.

MARSON, A. et al. Wnt signaling promotes reprogramming of somatic cells to pluripotency. Cell stem cell, v. 3, n. 2, p. 132-5, 7 ago. 2008 b.

MARTIN, G. R. Isolation of a pluripotent cell line from early mouse embryos cultured in medium conditioned by teratocarcinoma stem cells. Proceedings of the National Academy 
of Sciences of the United States of America, v. 78, n. 12, p. 7634-8, dez. 1981.

MARTIN, G. R.; EVANS, M. J. The morphology and growth of a pluripotent teratocarcinoma cell line and its derivatives in tissue culture. Cell, v. 2, n. 3, p. 163-172, 1974.

MASUI, S. et al. Pluripotency governed by Sox 2 via regulation of Oct3/4 expression in mouse embryonic stem cells. Nature cell biology, v. 9, n. 6, p. 625-35, jun. 2007.

MATHIEU, J.; RUOHOLA-BAKER, H. Regulation of stem cell populations by microRNAs. Advances in experimental medicine and biology, v. 786, p. 329-51, 2013.

MAZZOTTA, S. et al. Distinctive Roles of Canonical and Noncanonical Wnt Signaling in Human Embryonic Cardiomyocyte Development. Stem Cell Reports, v. 7, n. 4, p. 764-776, 2016.

MCLEAN, A. B. et al. Activin a efficiently specifies definitive endoderm from human embryonic stem cells only when phosphatidylinositol 3-kinase signaling is suppressed. Stem cells (Dayton, Ohio), v. 25, n. 1, p. 29-38, jan. 2007.

MENG, F. et al. MiR-30a-5p overexpression may overcome EGFR-inhibitor resistance through regulating PI3K/AKT signaling pathway in non-small cell lung cancer cell lines. Frontiers in Genetics, v. 7, n. NOV, p. 1-10, 2016.

MENG, X. et al. Inhibition of miR-363 protects cardiomyocytes against hypoxia-induced apoptosis through regulation of Notch signaling. Biomedicine \& pharmacotherapy = Biomedecine \& pharmacotherapie, v. 90, p. 509-516, jun. 2017.

MIMEAULT, M.; HAUKE, R.; BATRA, S. K. Stem cells: a revolution in therapeutics-recent advances in stem cell biology and their therapeutic applications in regenerative medicine and cancer therapies. Clinical pharmacology and therapeutics, v. 82, n. 3, p. 252-64, set. 2007.

MITSUI, K. et al. The homeoprotein Nanog is required for maintenance of pluripotency in mouse epiblast and ES cells. Cell, v. 113, n. 5, p. 631-42, 30 maio 2003.

MIYABAYASHI, T. et al. Wnt/beta-catenin/CBP signaling maintains long-term murine embryonic stem cell pluripotency. Proceedings of the National Academy of Sciences of the United States of America, v. 104, n. 13, p. 5668-73, 27 mar. 2007.

MOON, R. T. Wnt/beta-catenin pathway. Science's STKE : signal transduction knowledge environment, v. 2005, n. 271, p. cm1, 15 fev. 2005.

MOREY, L.; SANTANACH, A.; DI CROCE, L. Pluripotency and Epigenetic Factors in Mouse Embryonic Stem Cell Fate Regulation. Molecular and cellular biology, v. 35, n. 16, p. 2716-28, ago. 2015.

MORIGUCHI, T. et al. Purification and identification of a major activator for p38 from osmotically shocked cells. Activation of mitogen-activated protein kinase kinase 6 by osmotic shock, tumor necrosis factor-alpha, and $\mathrm{H} 2 \mathrm{O} 2$. The Journal of biological chemistry, v. 271, n. 43 , p. $26981-8,25$ out. 1996. 
MORITA, M. et al. mTORC1 controls mitochondrial activity and biogenesis through 4E-BPdependent translational regulation. Cell metabolism, v. 18, n. 5, p. 698-711, 5 nov. 2013.

MOUSSAIEFF, A. et al. Glycolysis-mediated changes in acetyl-CoA and histone acetylation control the early differentiation of embryonic stem cells. Cell Metabolism, v. 21, n. 3, p. 392-402, 2015.

MUKHERJI, S. et al. MicroRNAs can generate thresholds in target gene expression. Nature genetics, v. 43, n. 9, p. 854-9, 21 ago. 2011.

MURAKAMI, M. et al. mTOR is essential for growth and proliferation in early mouse embryos and embryonic stem cells. Molecular and cellular biology, v. 24, n. 15, p. 6710-8, ago. 2004.

NAGUIBNEVA, I. et al. The microRNA miR-181 targets the homeobox protein Hox-A11 during mammalian myoblast differentiation. Nature Cell Biology, v. 8, n. 3, p. 278-284, 2006.

NELSON, P. T.; WANG, W.-X.; RAJEEV, B. W. MicroRNAs (miRNAs) in neurodegenerative diseases. Brain pathology (Zurich, Switzerland), v. 18, n. 1, p. 130-8, 24 jan. 2008.

NICHOLS, J.; CHAMBERS, I.; SMITH, A. Derivation of germline competent embryonic stem cells with a combination of interleukin- 6 and soluble interleukin-6 receptor. Experimental cell research, v. 215, n. 1, p. 237-9, nov. 1994.

NIWA, H.; MIYAZAKI, J.; SMITH, A G. Quantitative expression of Oct-3/4 defines differentiation, dedifferentiation or self-renewal of ES cells. Nature genetics, v. 24, n. 4, p. 372-6, abr. 2000.

OEZTUERK-WINDER, F. et al. Regulation of human lung alveolar multipotent cells by a novel p38 $\alpha$ MAPK/miR-17-92 axis. The EMBO Journal, v. 31, n. 16, p. 3431-3441, 2012.

ØROM, U. A.; NIELSEN, F. C.; LUND, A. H. MicroRNA-10a binds the 5'UTR of ribosomal protein mRNAs and enhances their translation. Molecular cell, v. 30, n. 4, p. 460-71, 23 maio 2008.

ORTEGA, M. et al. A microRNA-mediated regulatory loop modulates NOTCH and MYC oncogenic signals in B- and T-cell malignancies. Leukemia, v. 29, n. 4, p. 968-76, 5 abr. 2015.

OTTOSEN, L. D. et al. Observations on intrauterine oxygen tension measured by fibre-optic microsensors. Reproductive BioMedicine Online, v. 13, n. 3, p. 380-385, 2006.

PALMIERI, S. L. et al. Oct-4 transcription factor is differentially expressed in the mouse embryo during establishment of the first two extraembryonic cell lineages involved in implantation. Developmental biology, v. 166, n. 1, p. 259-67, nov. 1994.

PAN, Q. et al. Transcriptional repression of miR-200 family members by Nanog in colon cancer cells induces epithelial-mesenchymal transition (EMT). Cancer letters, n. February, p. 
$1-13,2017$.

PAN, X. et al. Site-specific disruption of the Oct4/Sox 2 protein interaction reveals coordinated mesendodermal differentiation and the epithelial-mesenchymal transition. Journal of Biological Chemistry, v. 291, n. 35, p. 18353-18369, 2016.

PANOPOULOS, A. D. et al. The metabolome of induced pluripotent stem cells reveals metabolic changes occurring in somatic cell reprogramming. Cell Research, v. 22, n. 1, p. 168-177, 2012.

PARK, K. S. TGF-beta family signaling in embryonic stem cells. International Journal of Stem Cells, v. 4, n. 1, p. 18-23, 2011.

PARK, Y. R. et al. MicroRNA-30a-5p (miR-30a) regulates cell motility and EMT by directly targeting oncogenic TM4SF1 in colorectal cancer. Journal of Cancer Research and Clinical Oncology, 2017.

PASCOALINO, B. S. et al. Zika antiviral chemotherapy: identification of drugs and promising starting points for drug discovery from an FDA-approved library. F1000Research, v. 5, n. 0, p. 2523, 2016.

PEI, Y. FEI; LEI, Y.; LIU, X. QIANG. MiR-29a promotes cell proliferation and EMT in breast cancer by targeting ten eleven translocation 1. Biochimica et Biophysica Acta Molecular Basis of Disease, v. 1862, n. 11, p. 2177-2185, 2016.

PENG, X. DING et al. Dwarfism, impaired skin development, skeletal muscle atrophy, delayed bone development, and impeded adipogenesis in mice lacking Akt1 and Akt2. Genes and Development, v. 17, n. 11, p. 1352-1365, 2003.

PERA, M. F. et al. Regulation of human embryonic stem cell differentiation by BMP-2 and its antagonist noggin. Journal of cell science, v. 117, n. Pt 7, p. 1269-80, 1 mar. 2004.

PFAFFL, M. W. A new mathematical model for relative quantification in real-time RT-PCR. Nucleic acids research, v. 29, n. 9, p. e45, 1 maio 2001.

PILLAI, R. S. MicroRNA function: Multiple mechanisms for a tiny RNA ? MicroRNA function: Multiple mechanisms for a tiny RNA? Rna, v. 11, n. Bartel 2004, p. 1753-1761, 2005 .

PLAIA, T. W. et al. Characterization of a new NIH-registered variant human embryonic stem cell line, BG01V: a tool for human embryonic stem cell research. Stem cells (Dayton, Ohio), v. 24, n. 3, p. 531-46, mar. 2006.

QIAO, B. et al. MicroRNA-27a-3p Modulates the Wnt/ $\beta$-Catenin Signaling Pathway to Promote Epithelial-Mesenchymal Transition in Oral Squamous Carcinoma Stem Cells by Targeting SFRP1. Scientific reports, v. 7, n. April, p. 44688, 20 abr. 2017.

QIAO, Y. et al. Dual roles of histone H3 lysine 9 acetylation in human embryonic stem cell pluripotency and neural differentiation. The Journal of biological chemistry, v. 290, n. 4, p. 2508-20, 23 jan. 2015. 
QIN, H. et al. Regulation of apoptosis and differentiation by p53 in human embryonic stem cells. Journal of Biological Chemistry, v. 282, n. 8, p. 5842-5852, 2007.

REINHART, B. J. et al. The 21-nucleotide let-7 RNA regulates developmental timing in Caenorhabditis elegans. Nature, v. 403, n. 6772, p. 901-906, 2000.

REN, J. et al. MicroRNA and gene expression patterns in the differentiation of human embryonic stem cells. Journal of translational medicine, v. 7, p. 20, jan. 2009.

REUBINOFF, B. E. et al. Embryonic stem cell lines from human blastocysts: somatic differentiation in vitro. Nature biotechnology, v. 18, n. 4, p. 399-404, 2000.

RIANCHO, J. et al. MicroRNA Profile in Patients with Alzheimer's Disease: Analysis of miR-9-5p and miR-598 in Raw and Exosome Enriched Cerebrospinal Fluid Samples. Journal of Alzheimer's disease : JAD, v. 57, n. 2, p. 483-491, 2017.

RICHTER, A. et al. BMP4 promotes EMT and mesodermal commitment in human embryonic stem cells via SLUG and MSX2. Stem cells (Dayton, Ohio), v. 32, n. 3, p. 636-48, mar. 2014.

ROCK, F. L. et al. A family of human receptors structurally related to Drosophila Toll. Proceedings of the National Academy of Sciences, v. 95, n. 2, p. 588-593, 1998.

RODDA, D. J. et al. Transcriptional regulation of nanog by OCT4 and SOX2. The Journal of biological chemistry, v. 280, n. 26, p. 24731-7, 1 jul. 2005.

ROSENFELD, N. et al. MicroRNAs accurately identify cancer tissue origin. Nature biotechnology, v. 26, n. 4, p. 462-469, 2008.

ROTTIERS, V.; NÄÄR, A. M. MicroRNAs in metabolism and metabolic disorders. Nature reviews. Molecular cell biology, v. 13, n. 4, p. 239-50, 22 mar. 2012.

ROUGVIE, A. E.; MOSS, E. G. Developmental transitions in C. elegans larval stages. 1. ed. [s.1.] Elsevier Inc., 2013. v. 105

RUVKUN, G.; GIUSTO, J. The Caenorhabditis elegans heterochronic gene lin-14 encodes a nuclear protein that forms a temporal developmental switch. Nature, v. 338, n. 6213, p. 3139, 23 mar. 1989.

SAKAKI-YUMOTO, M.; KATSUNO, Y.; DERYNCK, R. TGF- $\beta$ family signaling in stem cells. Biochimica et biophysica acta, v. 1830, n. 2, p. 2280-96, fev. 2013.

SANDRA, F. et al. TNF inhibited the apoptosis by activation of Akt serine/threonine kinase in the human head and neck squamous cell carcinoma. Cellular signalling, v. 14, p. 771-8, 2002.

SATO, N. et al. Maintenance of pluripotency in human and mouse embryonic stem cells through activation of Wnt signaling by a pharmacological GSK-3-specific inhibitor. Nature medicine, v. 10, n. 1, p. 55-63, jan. 2004. 
SAYED, D.; ABDELlATIF, M. MicroRNAs in Development and Disease. Physiological Reviews, v. 91, n. 3, p. 827-887, 2011.

SCHNEUWLY, S.; KLEMENZ, R.; GEHRING, W. J. Redesigning the body plan of Drosophila by ectopic expression of the homoeotic gene Antennapedia. Nature, v. 325, n. 6107, p. 816-8, 1987.

SEMPERE, L. F. et al. Expression profiling of mammalian microRNAs uncovers a subset of brain-expressed microRNAs with possible roles in murine and human neuronal differentiation. Genome biology, v. 5, n. 3, p. R13, 2004.

SHAMBLOTT, M. J. et al. Derivation of pluripotent stem cells from cultured human primordial germ cells. Proceedings of the National Academy of Sciences, v. 95, n. 23, p. 13726-13731, 1998.

SHEN, E. et al. MicroRNAs involved in the mitogen-activated protein kinase cascades pathway during glucose-induced cardiomyocyte hypertrophy. American Journal of Pathology, v. 179, n. 2, p. 639-650, 2011.

SHEN, H. et al. MiR-222 promotes drug-resistance of breast cancer cells to adriamycin via modulation of PTEN/Akt/FOXO1 pathway. Gene, v. 596, p. 110-118, 2017.

SHI, Y. et al. Induced pluripotent stem cell technology: a decade of progress. Nature reviews. Drug discovery, v. 16, n. 2, p. 115-130, 2017.

SHI, Y.; MASSAGUÉ, J. Mechanisms of TGF-beta signaling from cell membrane to the nucleus. Cell, v. 113, n. 6, p. 685-700, 13 jun. 2003.

SHIN, J. et al. MiR-29b controls fetal mouse neurogenesis by regulating ICAT-mediated Wnt/ $\beta$-catenin signaling. Cell death \& disease, v. 5, p. e1473, 16 out. 2014.

SHOBHA VASUDEVAN, YINGCHUN TONG, J. A. S. Switching from Repression to Activation: MicroRNAs Can Up-Regulate Translation. Science (New York, N.Y.), v. 318, n. December, p. 1931-1934, 2007.

SHOOK, D.; KELLER, R. Mechanisms, mechanics and function of epithelial-mesenchymal transitions in early development. Mechanisms of development, v. 120, n. 11, p. 1351-83, nov. 2003.

SINGH, A. M. et al. Signaling network crosstalk in human pluripotent cells: A Smad2/3regulated switch that controls the balance between self-renewal and differentiation. Cell Stem Cell, v. 10, n. 3, p. 312-326, 2012.

SINGH, V. K. et al. Induced pluripotent stem cells: applications in regenerative medicine, disease modeling, and drug discovery. Frontiers in Cell and Developmental Biology, v. 3, n. February, p. 1-18, 2015.

SIOMI, H.; SIOMI, M. C. Posttranscriptional Regulation of MicroRNA Biogenesis in Animals. Molecular Cell, v. 38, n. 3, p. 323-332, 2010. 
SOLTER, D.; DOMINIS, M.; DAMJANOV, I. Embryo-derived teratocarcinoma: I. The role of strain and gender in the control of teratocarcinogenesis. International journal of cancer. Journal international du cancer, v. 24, n. 6, p. 770-2, 15 dez. 1979.

SOLTER, D.; SKREB, N.; DAMJANOV, I. Extrauterine growth of mouse egg-cylinders results in malignant teratoma. Nature, v. 227, n. 5257, p. 503-4, 1 ago. 1970.

SONG, B. et al. Tumor Suppressor Role of miR-363-3p in Gastric Cancer. Medical science monitor : international medical journal of experimental and clinical research, v. 21, p. 4074-80, 28 dez. 2015.

SONG, Y. et al. Sulfasalazine attenuates evading anticancer response of CD133-positive hepatocellular carcinoma cells. Journal of experimental \& clinical cancer research : CR, v. 36, n. 1, p. 38, 3 mar. 2017.

SOOD, P. et al. Cell-type-specific signatures of microRNAs on target mRNA expression. Proceedings of the National Academy of Sciences of the United States of America, v. 103, n. 8, p. 2746-51, 2006.

SPERGER, J. M. et al. Gene expression patterns in human embryonic stem cells and human pluripotent germ cell tumors. Proceedings of the National Academy of Sciences of the United States of America, v. 100, n. 23, p. 13350-5, 2003.

STADLER, B. et al. Characterization of microRNAs involved in embryonic stem cell states. Stem cells and development, v. 19, n. 7, p. 935-50, jul. 2010.

STADTFELD, M.; HOCHEDLINGER, K. Induced pluripotency: history, mechanisms, and applications. Genes \& development, v. 24, n. 20, p. 2239-63, 15 out. 2010.

STEWART, R. et al. Silencing of the expression of pluripotent driven-reporter genes stably transfected into human pluripotent cells. Regenerative medicine, v. 3, n. 4, p. 505-22, jul. 2008 .

SU, Z. et al. MicroRNAs in apoptosis, autophagy and necroptosis. Oncotarget, v. 6, n. 11, p. 8474-90, 2015.

SUBRAMANIAN, M. et al. MiR-29b downregulates canonical Wnt signaling by suppressing coactivators of $\beta$-catenin in human colorectal cancer cells. Journal of cellular biochemistry, v. 115, n. 11, p. 1974-84, nov. 2014.

SUBRAMANYAM, D. et al. Multiple targets of miR-302 and miR-372 promote reprogramming of human fibroblasts to induced pluripotent stem cells. Nature biotechnology, v. 29, n. 5, p. 443-8, maio 2011.

SUL, J.-Y. et al. Transcriptome transfer produces a predictable cellular phenotype. Proceedings of the National Academy of Sciences of the United States of America, v. 106, n. 18, p. 7624-9, 2009.

SUN, Y. et al. Signaling pathway of MAPK/ERK in cell proliferation, differentiation, migration, senescence and apoptosis. Journal of Receptors and Signal Transduction, v. 35, 
n. 6, p. 600-604, 2015.

SUNDARAMURTHY, V. et al. Deducing the mechanism of action of compounds identified in phenotypic screens by integrating their multiparametric profiles with a reference genetic screen. Nature Protocols, v. 9, n. 2, p. 474-490, 2014.

TADA, S. et al. Embryonic germ cells induce epigenetic reprogramming of somatic nucleus in hybrid cells. EMBO Journal, v. 16, n. 21, p. 6510-6520, 1997.

TAGLIAFIERRO, L. et al. Genetic analysis of $\alpha$-synuclein 3' untranslated region and its corresponding microRNAs in relation to Parkinson's compared to dementia with Lewy bodies. Alzheimer's \& dementia : the journal of the Alzheimer's Association, v. 5, n. April, p. 1-14, 18 abr. 2017.

TAKAHASHI, K.; YAMANAKA, S. Induction of Pluripotent Stem Cells from Mouse Embryonic and Adult Fibroblast Cultures by Defined Factors. Cell, v. 126, n. 4, p. 663-676, ago. 2006.

TAN, M.; WU, J.; CAI, Y. Suppression of Wnt signaling by the miR-29 family is mediated by demethylation of WIF-1 in non-small-cell lung cancer. Biochemical and biophysical research communications, v. 438, n. 4, p. 673-9, 6 set. 2013.

TAY, Y. et al. MicroRNAs to Nanog, Oct4 and Sox2 coding regions modulate embryonic stem cell differentiation. Nature, v. 455, n. 7216, p. 1124-8, 23 out. 2008.

TAYLOR, D. L. Past, present, and future of high content screening and the field of cellomics. Methods in molecular biology (Clifton, N.J.), v. 356, p. 3-18, jan. 2007.

TEO, A. K. K. et al. Activin and BMP4 synergistically promote formation of definitive endoderm in human embryonic stem cells. Stem Cells, v. 30, n. 4, p. 631-642, 2012.

THIERY, J. P. et al. Epithelial-Mesenchymal Transitions in Development and Disease. Cell, v. 139, n. 5, p. 871-890, 2009.

THOMSON, J. A. et al. Embryonic stem cell lines derived from human blastocysts. Science (New York, N.Y.), v. 282, n. 5391, p. 1145-7, 6 nov. 1998.

TOJKANDER, S.; GATEVA, G.; LAPPALAINEN, P. Actin stress fibers--assembly, dynamics and biological roles. Journal of cell science, v. 125, n. Pt 8, p. 1855-64, 15 abr. 2012.

TSUJI, T.; IBARAGI, S.; HU, G. Epithelial-mesenchymal transition and cell cooperativity in metastasis. Cancer research, v. 69, n. 18, p. 7135-9, 15 set. 2009.

TU, J. et al. MicroRNA-29b/Tet1 regulatory axis epigenetically modulates mesendoderm differentiation in mouse embryonic stem cells. Nucleic acids research, v. 43, n. 16, p. 780522,18 set. 2015 .

VALLIER, L. et al. Activin/Nodal signalling maintains pluripotency by controlling Nanog expression. Development (Cambridge, England), v. 136, n. 8, p. 1339-49, abr. 2009. 
VAUCHERET, $H$. et al. The action of ARGONAUTE1 in the miRNA pathway and its regulation by the miRNA pathway are crucial for plant development. Genes \& development, v. 18, n. 10 , p. $1187-97,15$ maio 2004.

WADDINGTON, C. H. The epigenotype. 1942. International journal of epidemiology, v. 41, n. 1, p. 10-13, 2012.

WANAMI, L. S. et al. Vascular endothelial growth factor-A stimulates Snail expression in breast tumor cells: implications for tumor progression. Experimental cell research, v. 314, n. 13, p. 2448-53, 1 ago. 2008.

WANG, B. et al. miR-29b suppresses tumor growth and metastasis in colorectal cancer via downregulating Tiam1 expression and inhibiting epithelial-mesenchymal transition. Cell death \& disease, v. 5, p. e1335, 2014.

WANG, D. et al. Quantitative functions of Argonaute proteins in mammalian development. Genes \& development, v. 26, n. 7, p. 693-704, 1 abr. 2012.

WANG, D. DAN et al. miR-222 induces Adriamycin resistance in breast cancer through PTEN/Akt/p27kip1 pathway. Tumor Biology, v. 37, n. 11, p. 15315-15324, 2016.

WANG, H. et al. Upregulation of miR-181s reverses mesenchymal transition by targeting KPNA4 in glioblastoma. Scientific reports, v. 5, p. 13072, 18 ago. 2015a.

WANG, K. et al. MiR-27a regulates Wnt/beta-catenin signaling through targeting SFRP1 in glioma. Neuroreport, v. 26, n. 12, p. 695-702, 19 ago. 2015 b.

WANG, L. et al. After Myocardial Ischemia-Reperfusion, miR-29a, and Let7 Could Affect Apoptosis through Regulating IGF-1. BioMed research international, v. 2015, p. 245412, $2015 \mathrm{c}$.

WANG, Y. et al. DGCR8 is essential for microRNA biogenesis and silencing of embryonic stem cell self-renewal. Nature genetics, v. 39, n. 3, p. 380-5, mar. 2007.

WANG, Y. et al. MicroRNAs in embryonic stem cells. Journal of cellular physiology, v. 218, n. 2, p. 251-5, fev. 2009.

WARD, P. S.; THOMPSON, C. B. Signaling in control of cell growth and metabolism. Cold Spring Harbor perspectives in biology, v. 4, n. 7, p. a006783, 1 jul. 2012.

WIENHOLDS, E.; PLASTERK, R. H. A. MicroRNA function in animal development. FEBS Letters, v. 579, n. 26, p. 5911-5922, 2005.

WILMUT, I. et al. Viable offspring derived from fetal and adult mammalian cells. Nature, v. 385, n. 6619, p. 810-3, 27 fev. 1997.

WON, K. Y. et al. MicroRNA-199b-5p is involved in the Notch signaling pathway in osteosarcoma. Human Pathology, v. 44, n. 8, p. 1648-1655, 2013.

WU, M. Y.; HILL, C. S. Tgf-beta superfamily signaling in embryonic development and 
homeostasis. Developmental cell, v. 16, n. 3, p. 329-43, mar. 2009.

XIA, X.; WONG, S. T. Concise review: a high-content screening approach to stem cell research and drug discovery. Stem cells (Dayton, Ohio), v. 30, n. 9, p. 1800-7, set. 2012.

XIAO, L.; YUAN, X.; SHARKIS, S. J. Activin A Maintains Self-Renewal and Regulates Fibroblast Growth Factor, Wnt, and Bone Morphogenic Protein Pathways in Human Embryonic Stem Cells. STEM CELLS, v. 24, n. 6, p. 1476-1486, jun. 2006.

XU, K. et al. MicroRNA-mediated target mRNA cleavage and 3'-uridylation in human cells. Scientific reports, v. 6, n. June, p. 30242, 21 jul. 2016.

XU, N. et al. MicroRNA-145 regulates OCT4, SOX2, and KLF4 and represses pluripotency in human embryonic stem cells. Cell, v. 137, n. 4, p. 647-58, 15 maio 2009.

XU, R.-H. et al. NANOG is a direct target of TGFbeta/activin-mediated SMAD signaling in human ESCs. Cell stem cell, v. 3, n. 2, p. 196-206, 7 ago. 2008.

YAMAMOTO, M. et al. Essential role for TIRAP in activation of the signalling cascade shared by TLR2 and TLR4. Nature, v. 420, n. 6913, p. 324-9, 21 nov. 2002.

YANG, T. et al. MiR-29 mediates TGF $\beta 1$-induced extracellular matrix synthesis through activation of PI3K-AKT pathway in human lung fibroblasts. Journal of Cellular Biochemistry, v. 114, n. 6, p. 1336-1342, 2013.

YEH, D.-W. et al. Interplay between Inflammation and Stemness in Cancer Cells: The Role of Toll-Like Receptor Signaling. Journal of Immunology Research, v. 2016, p. 1-14, 2016.

YOSHIDA, K. et al. Maintenance of the pluripotential phenotype of embryonic stem cells through direct activation of gp130 signalling pathways. Mechanisms of Development, v. 45, n. 2, p. 163-171, 1994.

YU, J. et al. Suppression of type I collagen expression by miR-29b via PI3K, Akt, and Sp1 pathway, part II: An in vivo investigation. Investigative Ophthalmology and Visual Science, v. 56, n. 10, p. 6019-6028, 2015a.

YU, J. S. L. et al. PI3K/mTORC2 regulates TGF- $\beta /$ Activin signalling by modulating Smad2/3 activity via linker phosphorylation. Nature Communications, v. 6, n. May, p. 7212, 2015b.

YU, J. S. L.; CUI, W. Proliferation, survival and metabolism: the role of PI3K/AKT/mTOR signalling in pluripotency and cell fate determination. Development, v. 143, n. 17, p. 3050 3060, 2016.

YU, X. et al. Notch Signaling Activation in Human Embryonic Stem Cells Is Required for Embryonic, but Not Trophoblastic, Lineage Commitment. Cell Stem Cell, v. 2, n. 5, p. 461471, 2008.

ZAMORE, P. D. et al. RNAi: double-stranded RNA directs the ATP-dependent cleavage of mRNA at 21 to 23 nucleotide intervals. Cell, v. 101, n. 1, p. 25-33, 2000. 
ZENG, Y.; WAGNER, E. J.; CULLEN, B. R. Both natural and designed micro RNAs can inhibit the expression of cognate mRNAs when expressed in human cells. Molecular Cell, v. 9, n. 6, p. 1327-1333, 2002.

ZHANG, J. X. et al. MiR-29c mediates epithelial-to-mesenchymal transition in human colorectal carcinoma metastasis via PTP4A and GNA13 regulation of $\beta$-catenin signaling. Annals of oncology : official journal of the European Society for Medical Oncology, v. 25, n. 11, p. 2196-204, nov. 2014.

ZHANG, P. et al. Short-term BMP-4 treatment initiates mesoderm induction in human embryonic stem cells. Blood, v. 111, n. 4, p. 1933-41, 15 fev. 2008.

ZHANG, X. et al. Gene regulatory networks mediating canonical Wnt signal-directed control of pluripotency and differentiation in embryo stem cells. Stem cells (Dayton, Ohio), v. 31, n. 12, p. 2667-79, dez. 2013.

ZHANG, Z. et al. miR-27 promotes human gastric cancer cell metastasis by inducing epithelial-to-mesenchymal transition. Cancer genetics, v. 204, n. 9, p. 486-91, set. 2011.

ZHAO, N. et al. miR-27a-3p suppresses tumor metastasis and VM by down-regulating VEcadherin expression and inhibiting EMT: an essential role for Twist-1 in HCC. Scientific reports, v. 6, n. February, p. 23091, 16 mar. 2016.

ZHENG, J. et al. miR-103 Promotes Proliferation and Metastasis by Targeting KLF4 in Gastric Cancer. International journal of molecular sciences, v. 18, n. 5, p. 910, 26 abr. 2017.

ZHONG, M.; BIAN, Z.; WU, Z. MiR-30a suppresses cell migration and invasion through downregulation of PIK3CD in colorectal carcinoma. Cellular Physiology and Biochemistry, v. 31, n. 2-3, p. 209-218, 2013.

ZHOU, A-D. et al. $\beta$-Catenin/LEF1 transactivates the microRNA-371-373 cluster that modulates the Wnt/ $\beta$-catenin-signaling pathway. Oncogene, v. 31, n. 24, p. 2968-78, 2012a.

ZHOU, J. et al. mTOR supports long-term self-renewal and suppresses mesoderm and endoderm activities of human embryonic stem cells. Proceedings of the National Academy of Sciences of the United States of America, v. 106, n. 19, p. 7840-5, 12 maio 2009.

ZHOU, J.-N. et al. MicroRNA-125b attenuates epithelial-mesenchymal transitions and targets stem-like liver cancer cells through small mothers against decapentaplegic 2 and 4 . Hepatology (Baltimore, Md.), v. 62, n. 3, p. 801-15, set. 2015.

ZHOU, Q. et al. Complete Meiosis from Embryonic Stem Cell-Derived Germ Cells in Vitro. Cell Stem Cell, v. 18, n. 3, p. 330-340, 2016.

ZHOU, W. et al. HIF $1 \alpha$ induced switch from bivalent to exclusively glycolytic metabolism during ESC-to-EpiSC/hESC transition. The EMBO journal, v. 31, n. 9, p. 2103-16, 2 maio $2012 b$.

ZHOU, W. et al. miR-217 inhibits triple-negative breast cancer cell growth, migration, and 
invasion through targeting KLF5. PLOS ONE, v. 12, n. 4, p. e0176395, 24 abr. 2017.

ZHU, S. et al. Reprogramming of human primary somatic cells by OCT4 and chemical compounds. Cell stem cell, v. 7, n. 6, p. 651-5, 3 dez. 2010. 


\section{Anexos}




\section{Anexo I}

O sistema de imageamento celular e análise ImageXpress Micro XLS, utilizado para os experimentos de HCA, é composto dos seguintes itens:

- Software MetaXpress para manuseio do microscópio e análise de imagens;

- Laser autofocus de alta velocidade;

- Fonte de luz de estado sólido;

- Câmera CMOS de 4.66MP;

- Câmara de controle ambiental;

- Fonte para luz transmitida;

- Lentes Objetivas: 4X (PhL, Abertura numérica: 0.013, Distância de Trabalho: 16.2mm), 10X (Ph1, Abertura numérica: 0.30, Distância de Trabalho: 16.0), 20X (Ph1, Abertura numérica: 0.50, Distância de Trabalho: 2.1mm), 40X ( $\mathrm{Ph} 2$, Abertura numérica: 0.75, Distância de Trabalho: 0,72mm);

- Cubos de filtros para detecção de fluorescência: DAPI, FITC, Cy3, Texas Red, Cy5 (detalhes abaixo).

\begin{tabular}{|c|c|c|c|}
\hline Cubos de Filtros & Ex/Em & $\begin{array}{l}\text { Visualizaçabo do } \\
\text { Espectro (1lustrativo) }\end{array}$ & Exemplos de Fluoroforos \\
\hline DAPI & $37(<25) 467(-30)$ & & Alexa Fluor 350 AMCA DxLigtk 350 \\
\hline FITC & $482( \pm 15) / 520( \pm 20)$ & & Nens Fluor 488, tuorescein, FIC, Dyligh 488 \\
\hline 68 & $531( \pm 20) 593(+20)$ & & $\begin{array}{c}\text { Alexa Fluer 546. Alesa Fuor 555, Dulent 550 } \\
\text { Cy3TRITC }\end{array}$ \\
\hline Texas Red & $562( \pm 20) 624(\div 20)$ & & Alexa Fluor 594, Texis Red, Dy ight 594 \\
\hline Cy5 & $623(+20) 692( \pm 20)$ & & Alexa Fluor $647,0,5$, Duxight 650 \\
\hline
\end{tabular}




\section{Anexo II}

Tabela S1: Informações sobre as moléculas de miR mimics e suas respectivas contrapartes biológicas.

\begin{tabular}{|c|c|c|c|c|c|c|}
\hline Nome_Ambion & Acc_Mad. & ID_Ambion & Nome_miRBase & Sequência_Maduro & Acc_SL & Nome_SL \\
\hline hsa-miR-17* & MIMAT0000071 & PM12246 & hsa-miR-17-3p & ACUGCAGUGAAGGCACUUGUAG & MI0000071 & hsa-mir-17 \\
\hline hsa-miR-18a & MIMAT0000072 & PM12973 & hsa-miR-18a-5p & UAAGGUGCAUCUAGUGCAGAUAG & MI0000072 & hsa-mir- $18^{\mathrm{a}}$ \\
\hline hsa-miR-18b & MIMAT0001412 & PM10466 & hsa-miR-18b-5p & UAAGGUGCAUCUAGUGCAGUUAG & MI0001518 & hsa-mir-18b \\
\hline hsa-miR-19a & MIMAT0000073 & PM10649 & hsa-miR-19a-3p & UGUGCAAAUCUAUGCAAAACUGA & MI0000073 & hsa-mir-19 \\
\hline hsa-miR-19b & MIMAT0000074 & PM10629 & hsa-miR-19b-3p & UGUGCAAAUCCAUGCAAAACUGA & MI0000075 & hsa-mir-19b-2 \\
\hline hsa-miR-19b & MIMAT0000074 & PM10629 & hsa-miR-19b-3p & UGUGCAAAUCCAUGCAAAACUGA & MI0000074 & hsa-mir-19b-1 \\
\hline hsa-miR-20a & MIMAT0000075 & PM10057 & hsa-miR-20a-5p & UAAAGUGCUUAUAGUGCAGGUAG & MI0000076 & hsa-mir-20 $0^{a}$ \\
\hline hsa-miR-20b & MIMAT0001413 & PM10975 & hsa-miR-20b-5p & CAAAGUGCUCAUAGUGCAGGUAG & MI0001519 & hsa-mir-20b \\
\hline hsa-miR-21 & MIMAT0000076 & PM10206 & hsa-miR-21-5p & UAGCUUAUCAGACUGAUGUUGA & MI0000077 & hsa-mir-21 \\
\hline hsa-miR-22 & MIMAT0000077 & PM10203 & hsa-miR-22-3p & AAGCUGCCAGUUGAAGAACUGU & MI0000078 & hsa-mir-22 \\
\hline hsa-miR-23a & MIMAT0000078 & PM10644 & hsa-miR-23a-3p & AUCACAUUGCCAGGGAUUUCC & MI0000079 & hsa-mir- $23^{a}$ \\
\hline hsa-miR-24 & MIMAT0000080 & PM10737 & hsa-miR-24-3p & UGGCUCAGUUCAGCAGGAACAG & MI0000080 & hsa-mir-24-1 \\
\hline hsa-miR-24 & MIMAT0000080 & PM10737 & hsa-miR-24-3p & UGGCUCAGUUCAGCAGGAACAG & MI0000081 & hsa-mir-24-2 \\
\hline hsa-miR-27a & MIMAT0000084 & PM10939 & hsa-miR-27a-3p & UUCACAGUGGCUAAGUUCCGC & MI0000085 & hsa-mir-27 \\
\hline hsa-miR-29a & MIMAT0000086 & PM12499 & hsa-miR-29a-3p & UAGCACCAUCUGAAAUCGGUUA & MI0000087 & hsa-mir-29a \\
\hline hsa-miR-29b & MIMAT0000100 & PM10103 & hsa-miR-29b-3p & UAGCACCAUUUGAAAUCAGUGUU & MI0000105 & hsa-mir-29b-1 \\
\hline hsa-miR-30a & MIMAT0000087 & PM11062 & hsa-miR-30a-5p & UGUAAACAUCCUCGACUGGAAG & MI0000088 & hsa-mir- $30^{\text {a }}$ \\
\hline hsa-miR-92a & MIMAT0000092 & PM10916 & hsa-miR-92a-3p & UAUUGCACUUGUCCCGGCCUGU & MI0000094 & hsa-mir-92a-2 \\
\hline hsa-miR-92a & MIMAT0000092 & PM10916 & hsa-miR-92a-3p & UAUUGCACUUGUCCCGGCCUGU & MI0000093 & hsa-mir-92a-1 \\
\hline hsa-miR-101 & MIMAT0000099 & PM11414 & hsa-miR-101-3p & UACAGUACUGUGAUAACUGAA & MI0000103 & hsa-mir-101-1 \\
\hline hsa-miR-101 & MIMAT0000099 & PM11414 & hsa-miR-101-3p & UACAGUACUGUGAUAACUGAA & MI0000739 & hsa-mir-101-2 \\
\hline
\end{tabular}


ANEXOS

\begin{tabular}{|c|c|c|c|c|c|c|}
\hline hsa-miR-106a & MIMAT0000103 & PM12567 & hsa-miR-106a-5p & AAAAGUGCUUACAGUGCAGGUAG & MI0000113 & hsa-mir-106a \\
\hline hsa-miR-145 & MIMAT0000437 & PM11480 & hsa-miR-145-5p & GUCCAGUUUUCCCAGGAAUCCCU & MI0000461 & hsa-mir-145 \\
\hline hsa-miR-181d & MIMAT0002821 & PM12522 & hsa-miR-181d-5p & AACAUUCAUUGUUGUCGGUGGGU & MI0003139 & hsa-mir-181d \\
\hline hsa-miR-222 & MIMAT0000279 & PM11376 & hsa-miR-222-3p & AGCUACAUCUGGCUACUGGGU & MI0000299 & hsa-mir-222 \\
\hline hsa-miR-302a & MIMAT0000684 & PM10936 & hsa-miR-302a-3p & UAAGUGCUUCCAUGUUUUGGUGA & MI0000738 & hsa-mir-302a \\
\hline hsa-miR-302a* & MIMAT0000683 & PM12557 & hsa-miR-302a-5p & ACUUAAACGUGGAUGUACUUGCU & MI0000738 & hsa-mir-302a \\
\hline hsa-miR-302b & MIMAT0000715 & PM10081 & hsa-miR-302b-3p & UAAGUGCUUCCAUGUUUUAGUAG & MI0000772 & hsa-mir-302b \\
\hline hsa-miR-302b* & MIMAT0000714 & PM12916 & hsa-miR-302b-5p & ACUUUAACAUGGAAGUGCUUUC & MI0000772 & hsa-mir-302b \\
\hline hsa-miR-302c & MIMAT0000717 & PM10571 & hsa-miR-302c-3p & UAAGUGCUUCCAUGUUUCAGUGG & MI0000773 & hsa-mir-302c \\
\hline hsa-miR-302d & MIMAT0000718 & PM10927 & hsa-miR-302d-3p & UAAGUGCUUCCAUGUUUGAGUGU & MI0000774 & hsa-mir-302d \\
\hline hsa-miR-363 & MIMAT0000707 & PM10149 & hsa-miR-363-3p & AAUUGCACGGUAUCCAUCUGUA & MI0000764 & hsa-mir-363 \\
\hline hsa-miR-371-3p & MIMAT0000723 & PM12262 & hsa-miR-371a-3p & AAGUGCCGCCAUCUUUUGAGUGU & MI0000779 & hsa-mir-371a \\
\hline hsa-miR-372 & MIMAT0000724 & PM10165 & hsa-miR-372-3p & AAAGUGCUGCGACAUUUGAGCGU & MI0000780 & hsa-mir-372 \\
\hline hsa-miR-373 & MIMAT0000726 & PM11024 & hsa-miR-373-3p & GAAGUGCUUCGAUUUUGGGGUGU & MI0000781 & hsa-mir-373 \\
\hline
\end{tabular}

Acc_Mad. = número de acesso da fita de miRNA madura; Acc_SL = número de acesso da fita de pré-miR; Nome_SL = nomenclatura aplicada para a fita de pré-miR. 


\section{Anexo III}

Aqui estão apresentadas as figuras das vias de sinalização identificadas por meio da ferramenta DAVID, utilizando-se os alvos compartilhados entre os miRNAs de cada cluster fenotípico observado na linhagem de célula de carcinoma embrionário NTera-2.

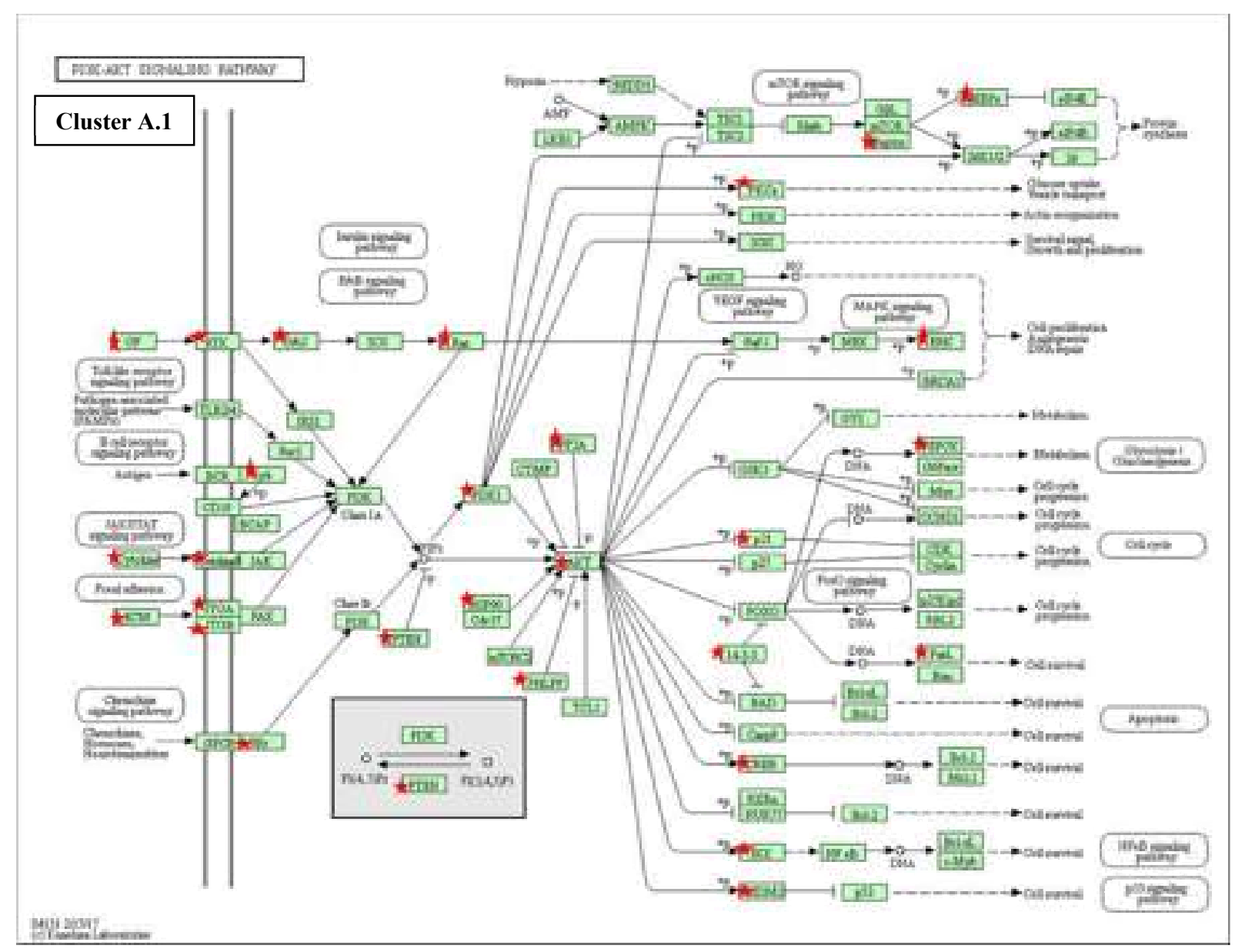

Figura S01. Representação da via de sinalização PI3K-AKT gerada a partir da ferramenta DAVID com a análise dos genes alvos compartilhados entre os miRNAs do cluster A.1(em NTera-2), onde os grupos de genes (associados por suas funções biológicas na via) marcados com as estrelas vermelhas são aqueles em que um ou mais alvos do cluster se encontram. 


\section{ANEXOS}

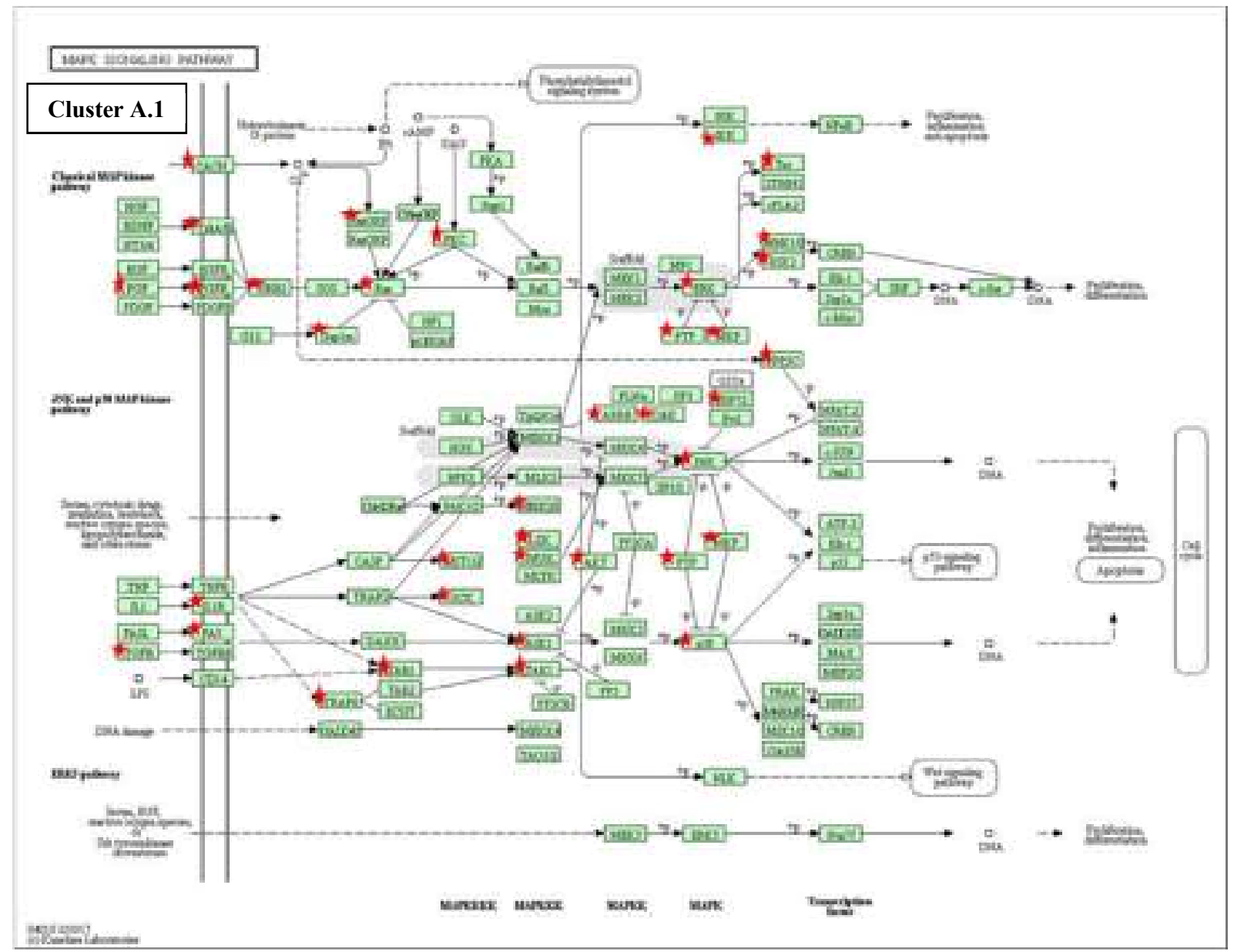

Figura S02. Representação da via de sinalização de MAPK gerada a partir da ferramenta DAVID com a análise dos genes alvos compartilhados entre os miRNAs do cluster A.1 (em NTera-2), onde os grupos de genes (associados por suas funções biológicas na via) marcados com as estrelas vermelhas são aqueles em que um ou mais alvos do cluster se encontram. 


\section{ANEXOS}

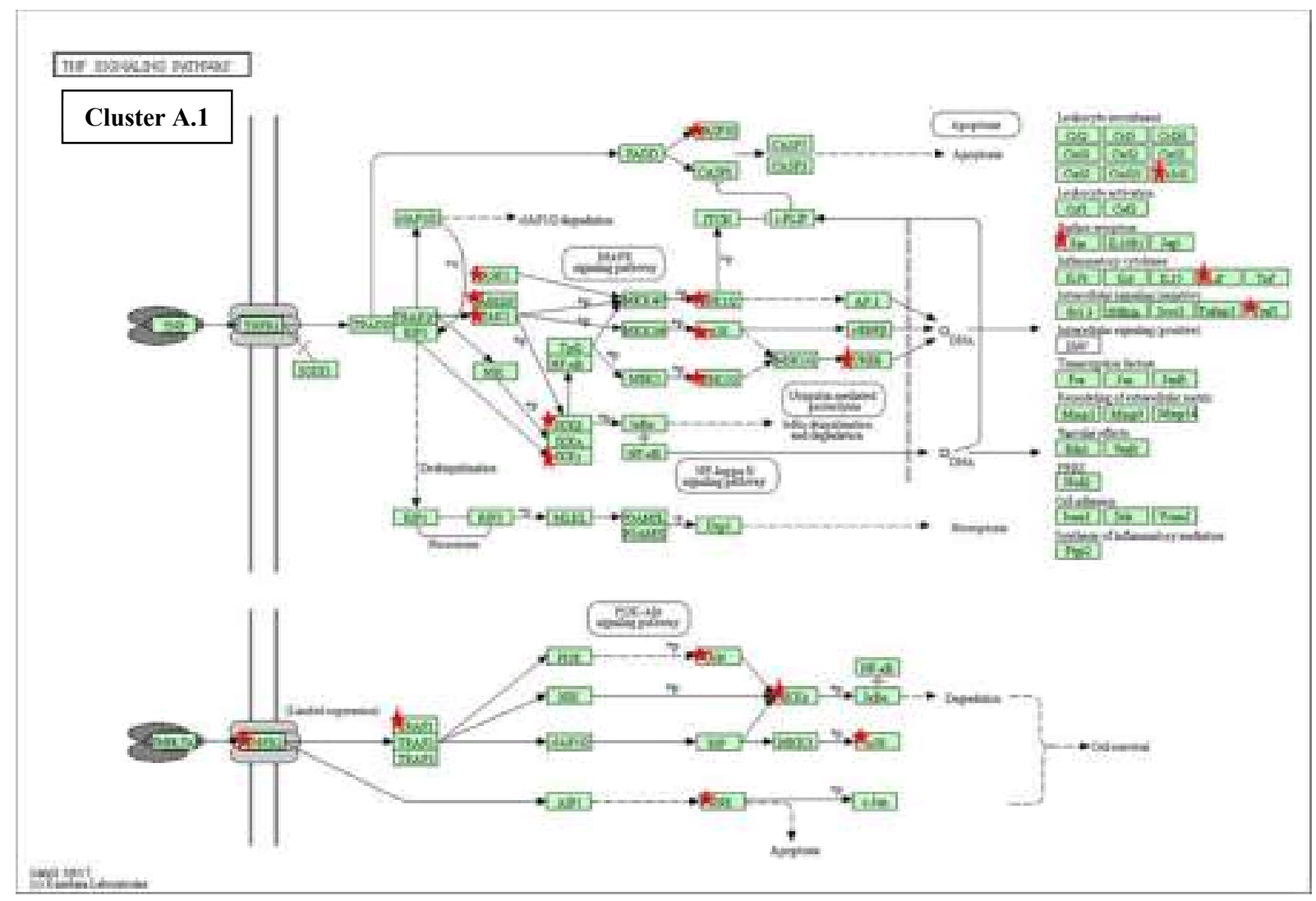

Figura S03. Representação da via de sinalização de TNF gerada a partir da ferramenta DAVID com a análise dos genes alvos compartilhados entre os miRNAs do cluster A.1 (em NTera-2), onde os grupos de genes (associados por suas funções biológicas na via) marcados com as estrelas vermelhas são aqueles em que um ou mais alvos do cluster se encontram. 


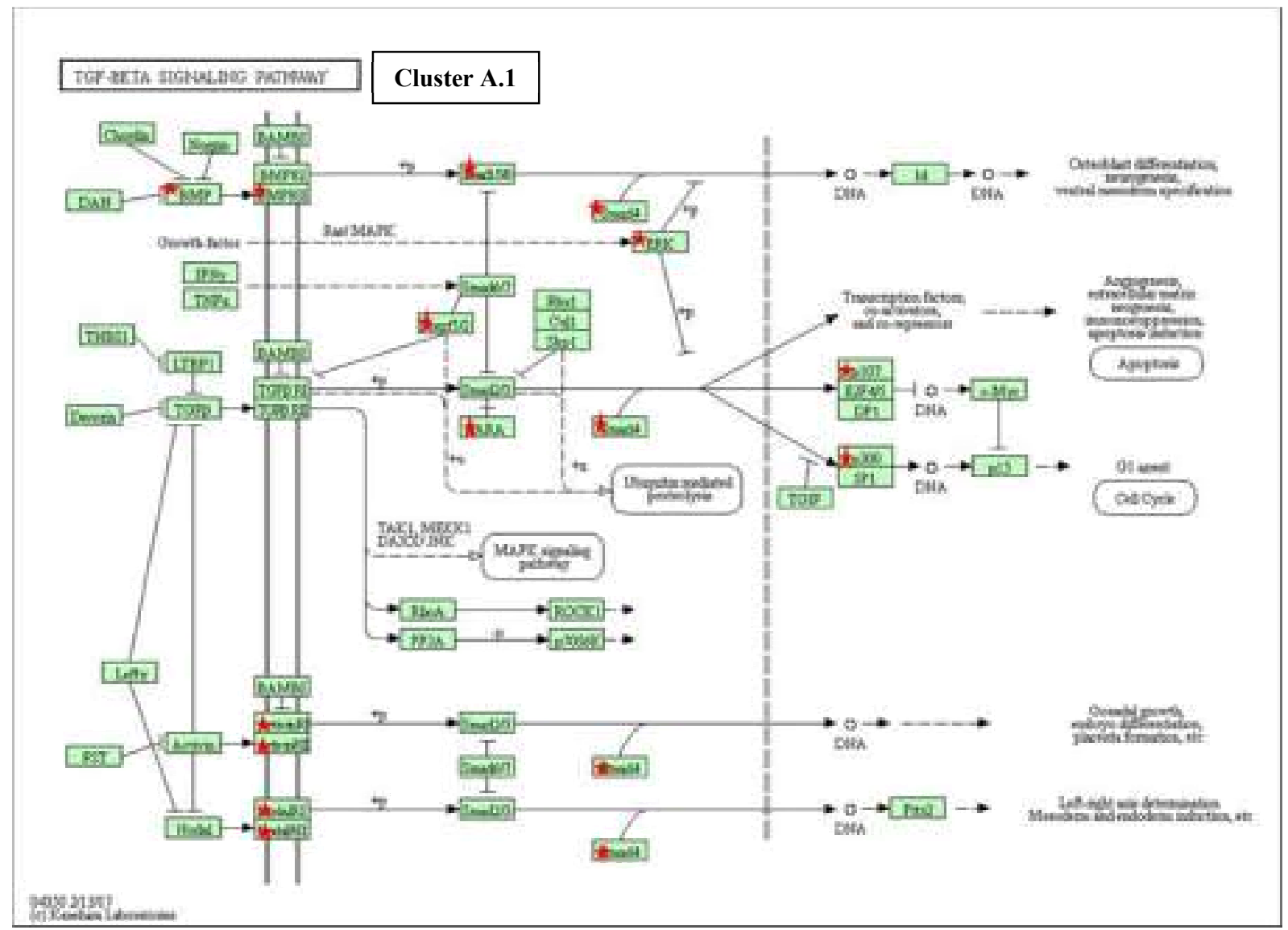

Figura S04. Representação da via de sinalização de TGF $\beta$ gerada a partir da ferramenta DAVID com a análise dos genes alvos compartilhados entre os miRNAs do cluster A.1 (em NTera-2), onde os grupos de genes (associados por suas funções biológicas na via) marcados com as estrelas vermelhas são aqueles em que um ou mais alvos do cluster se encontram. 


\section{ANEXOS}

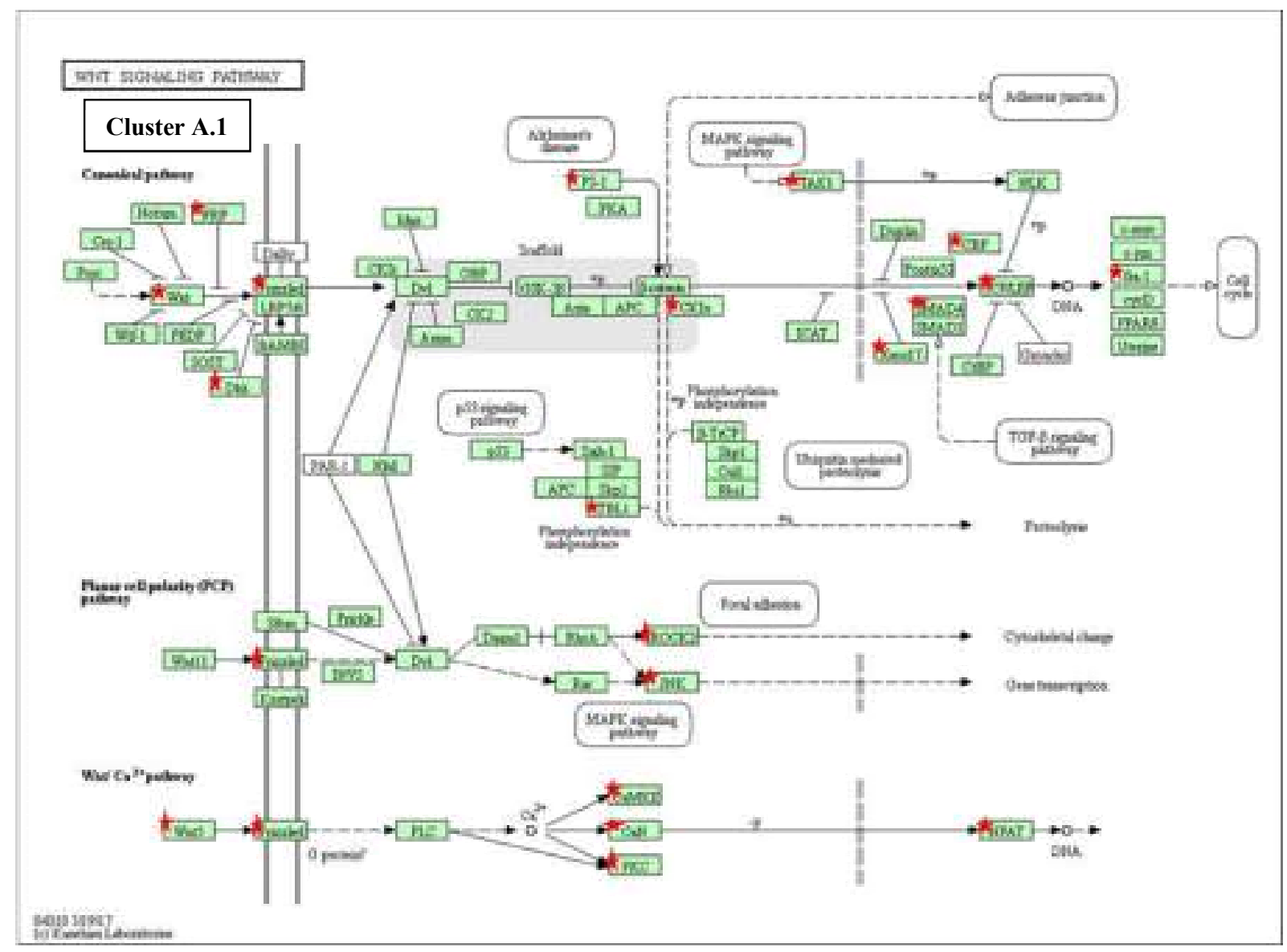

Figura S05. Representação da via de sinalização de WNT gerada a partir da ferramenta DAVID com a análise dos genes alvos compartilhados entre os miRNAs do cluster A.1 (em NTera-2), onde os grupos de genes (associados por suas funções biológicas na via) marcados com as estrelas vermelhas são aqueles em que um ou mais alvos do cluster se encontram. 


\section{ANEXOS}

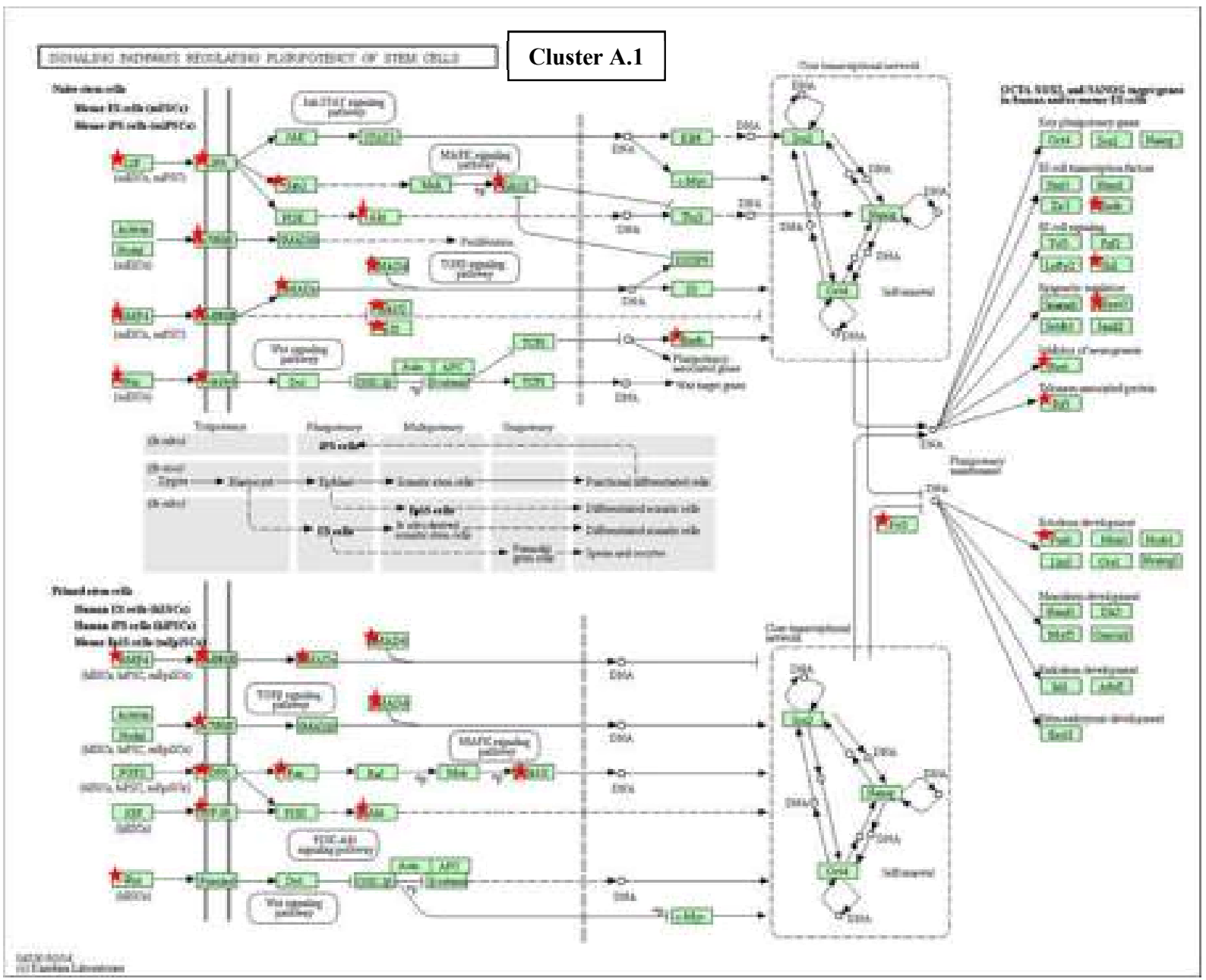

Figura S06. Representação das vias de sinalização regulando a pluripotência em células-tronco gerada a partir da ferramenta DAVID com a análise dos genes alvos compartilhados entre os miRNAs do cluster A.1 (em NTera-2), onde os grupos de genes (associados por suas funções biológicas na via) marcados com as estrelas vermelhas são aqueles em que um ou mais alvos do cluster se encontram. 


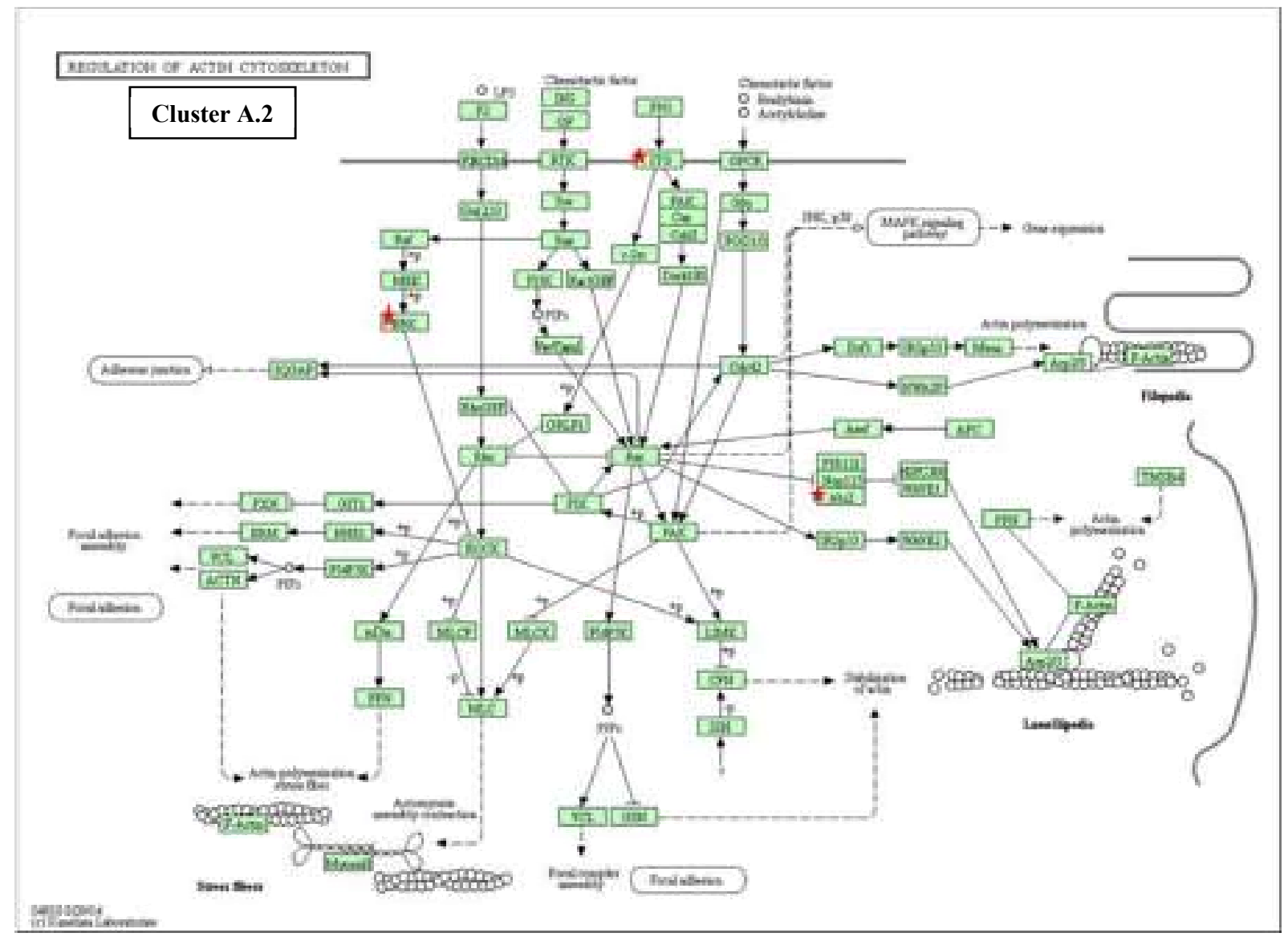

Figura S07. Representação da via de regulação do citoesqueleto de actina gerada a partir da ferramenta DAVID com a análise dos genes alvos compartilhados entre os miRNAs do cluster A.2 (em NTera-2), onde os grupos de genes (associados por suas funções biológicas na via) marcados com as estrelas vermelhas são aqueles em que um ou mais alvos do cluster se encontram. 


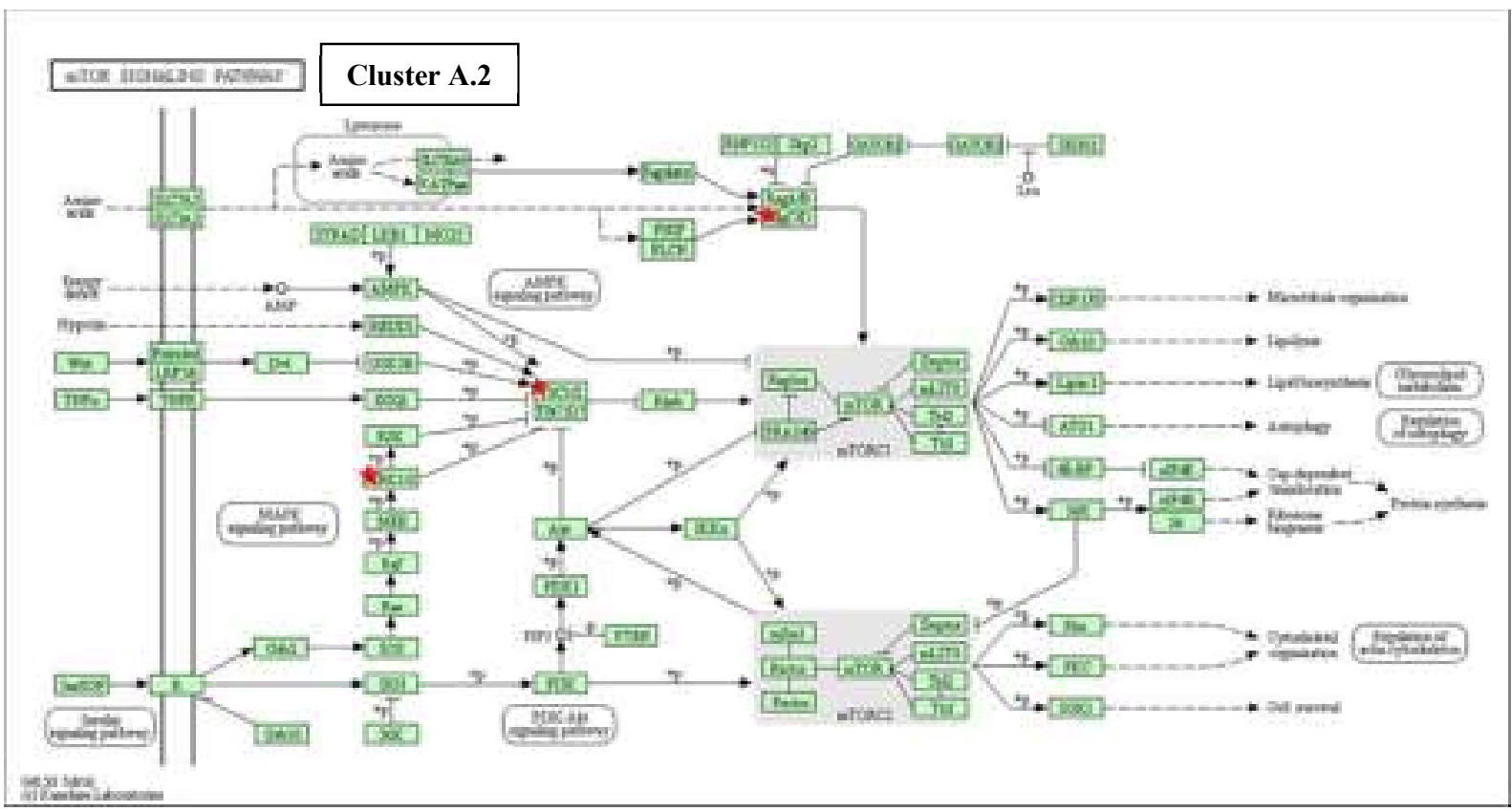

Figura S08. Representação da via de sinalização de mTOR gerada a partir da ferramenta DAVID com a análise dos genes alvos compartilhados entre os miRNAs do cluster A.2 (em NTera-2), onde os grupos de genes (associados por suas funções biológicas na via) marcados com as estrelas vermelhas são aqueles em que um ou mais alvos do cluster se encontram. 


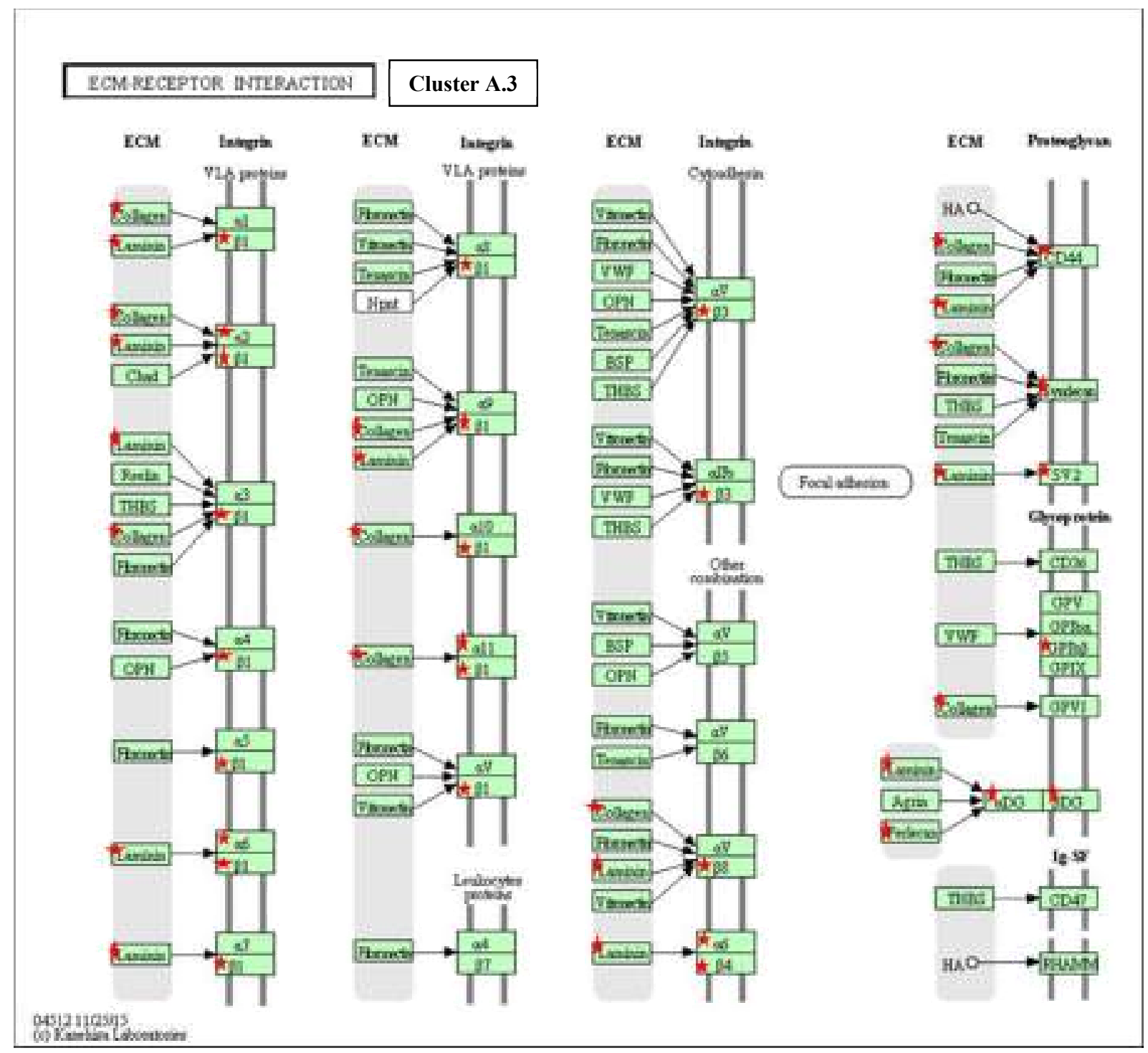

Figura S09. Representação da via de receptores de matriz extracelular a partir da ferramenta DAVID com a análise dos genes alvos compartilhados entre os miRNAs do cluster A.3 (em NTera-2), onde os grupos de genes (associados por suas funções biológicas na via) marcados com as estrelas vermelhas são aqueles em que um ou mais alvos do cluster se encontram. 


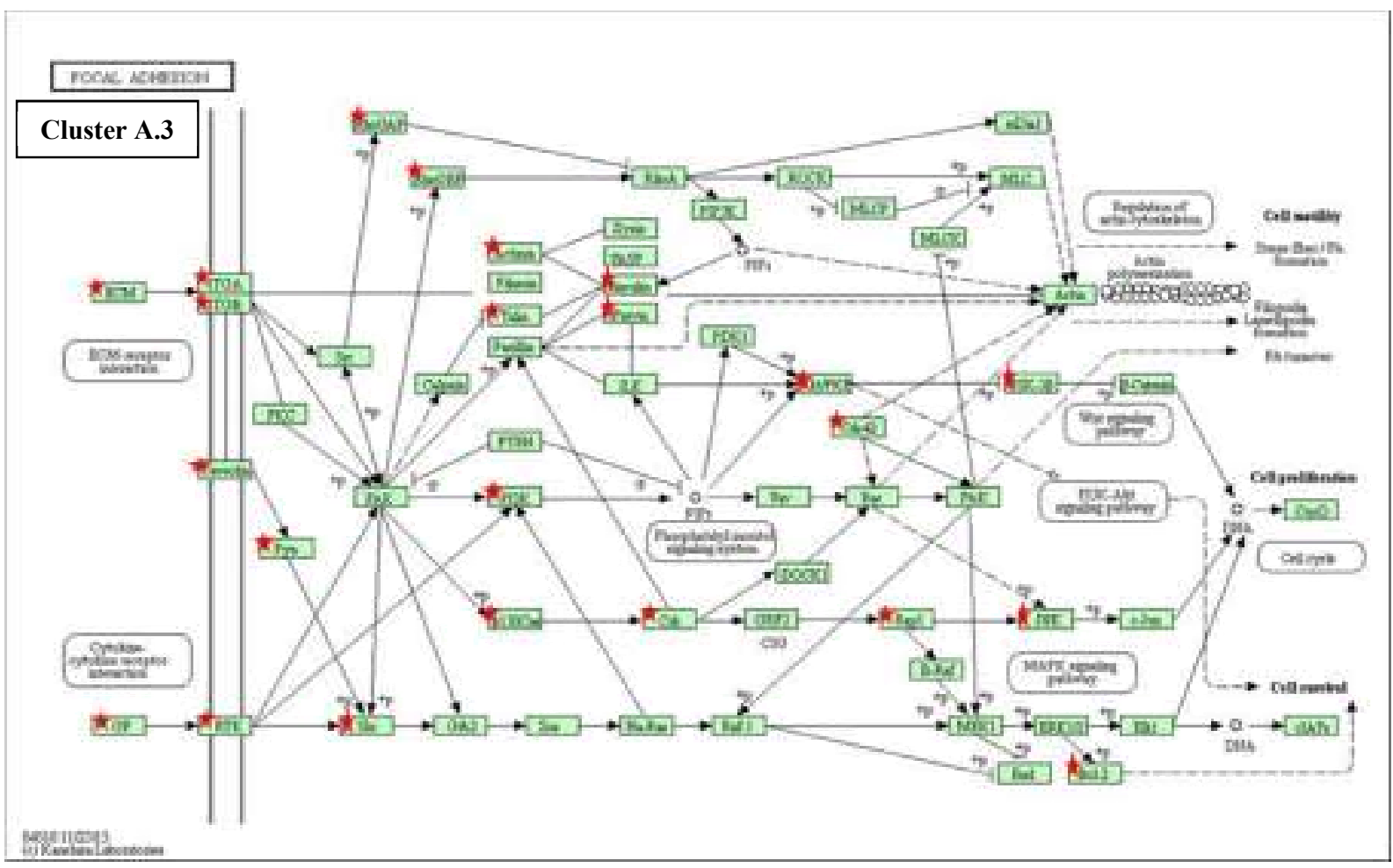

Figura S10. Representação da via de adesão focal a partir da ferramenta DAVID com a análise dos genes alvos compartilhados entre os miRNAs do cluster A.3 (em NTera-2), onde os grupos de genes (associados por suas funções biológicas na via) marcados com as estrelas vermelhas são aqueles em que um ou mais alvos do cluster se encontram. 
ANEXOS

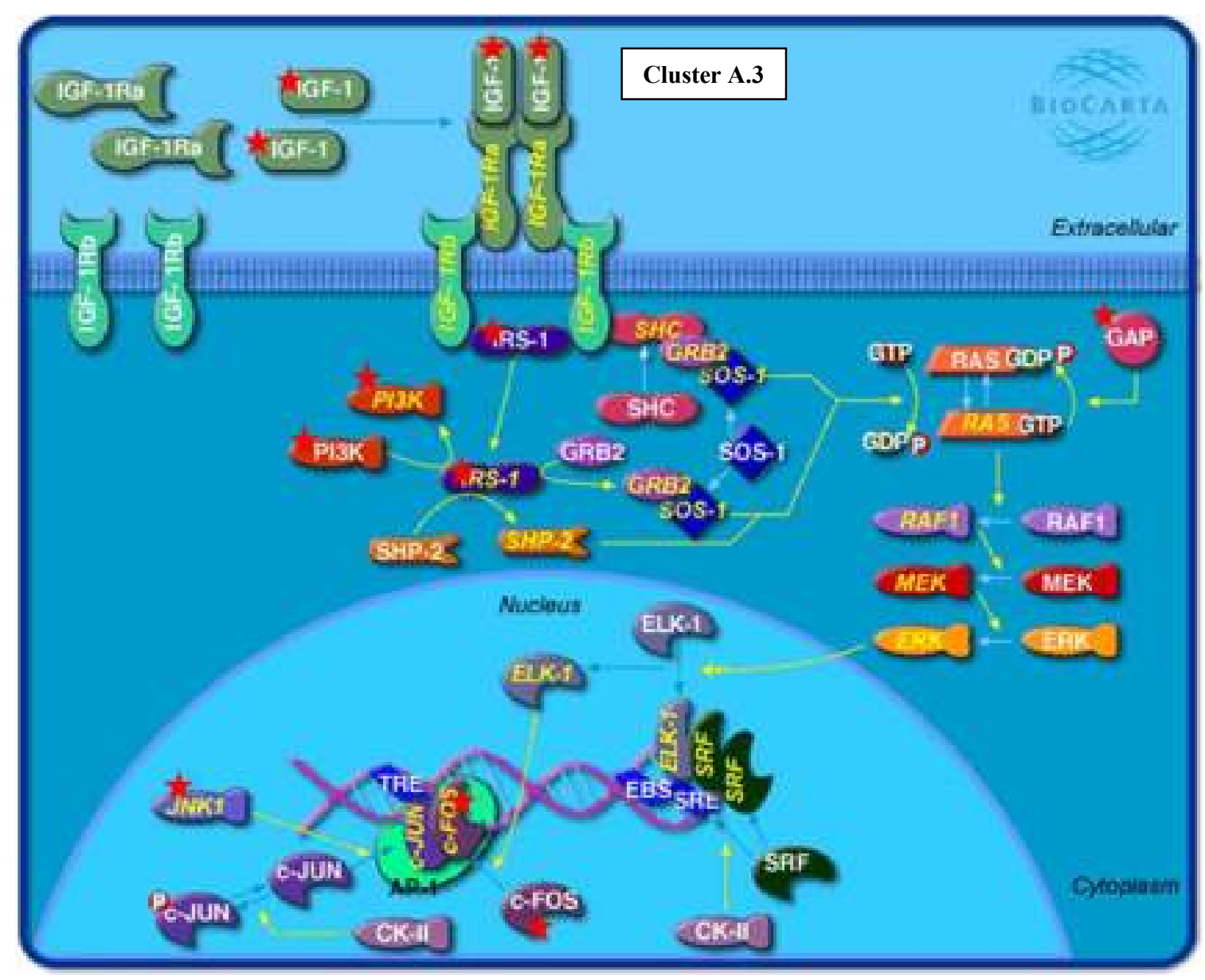

Figura S11. Representação da via de sinalização de IGF-1 a partir da ferramenta DAVID com a análise dos genes alvos compartilhados entre os miRNAs do cluster A.3 (em NTera-2), onde os grupos de genes (associados por suas funções biológicas na via) marcados com as estrelas vermelhas são aqueles em que um ou mais alvos do cluster se encontram. 


\section{ANEXOS}

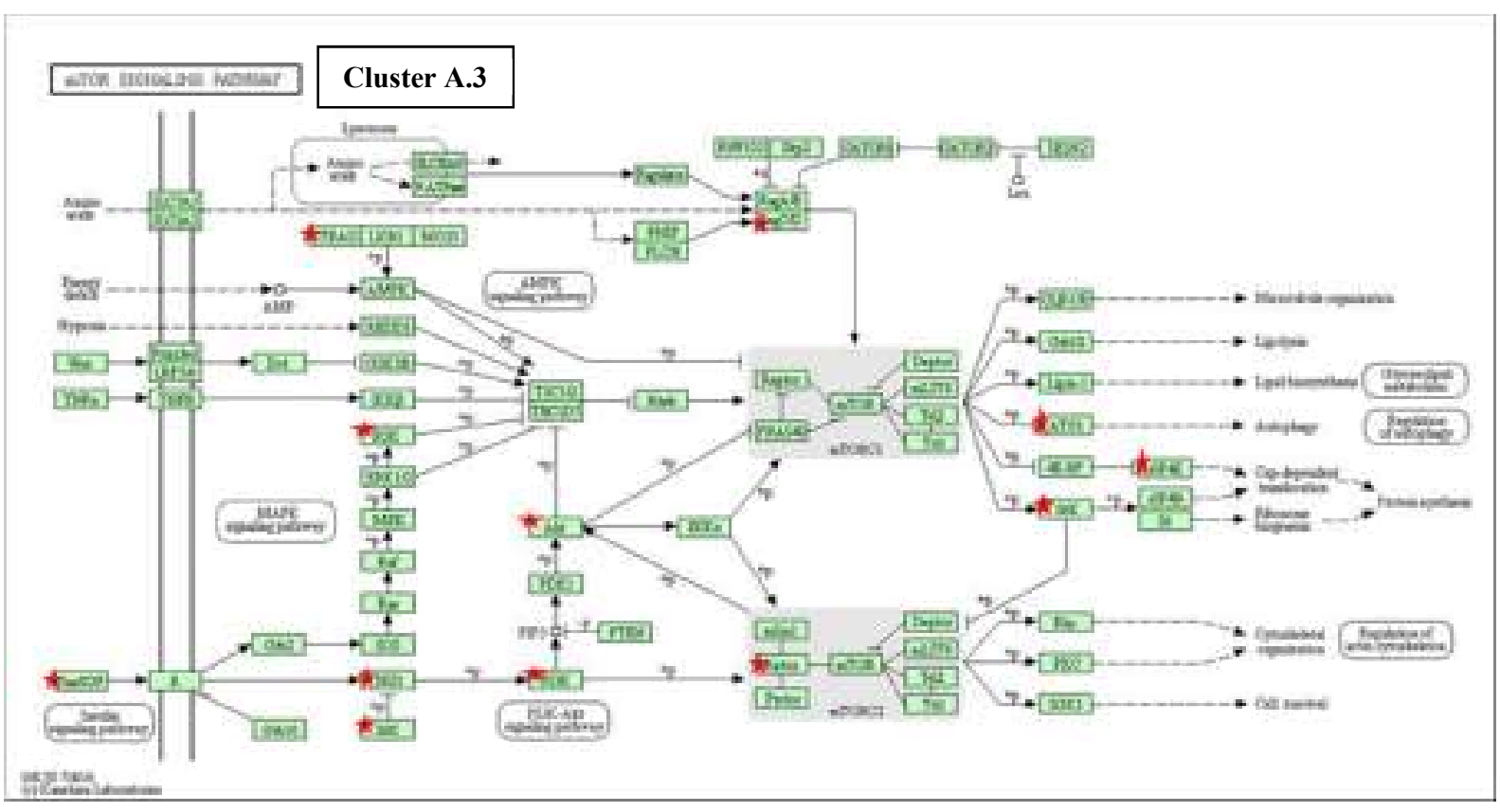

Figura S12. Representação da via de sinalização de mTOR a partir da ferramenta DAVID com a análise dos genes alvos compartilhados entre os miRNAs do cluster A.3 (em NTera-2), onde os grupos de genes (associados por suas funções biológicas na via) marcados com as estrelas vermelhas são aqueles em que um ou mais alvos do cluster se encontram. 


\section{ANEXOS}

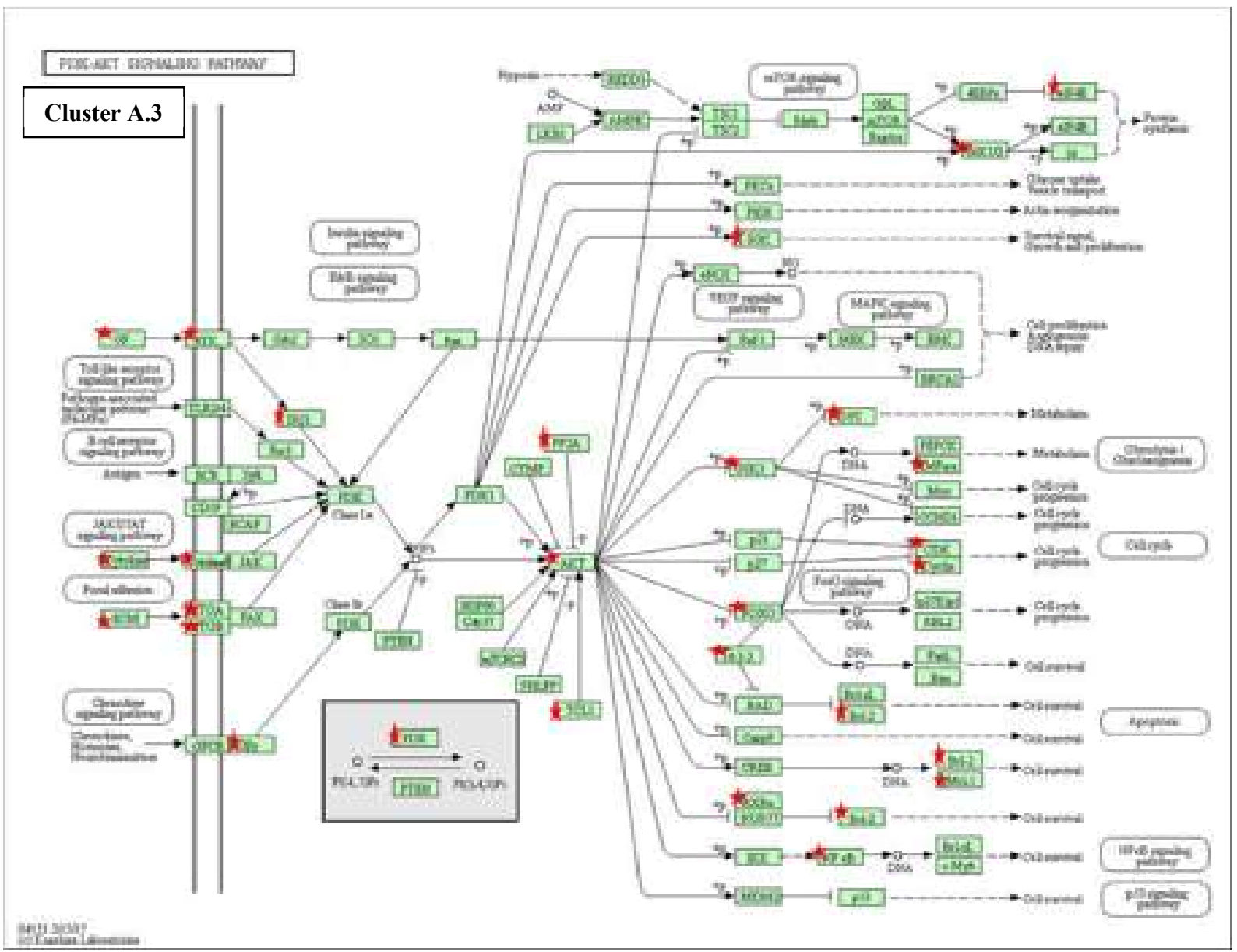

Figura S13. Representação da via de sinalização de PI3K-AKT a partir da ferramenta DAVID com a análise dos genes alvos compartilhados entre os miRNAs do cluster A.3 (em NTera-2), onde os grupos de genes (associados por suas funções biológicas na via) marcados com as estrelas vermelhas são aqueles em que um ou mais alvos do cluster se encontram. 


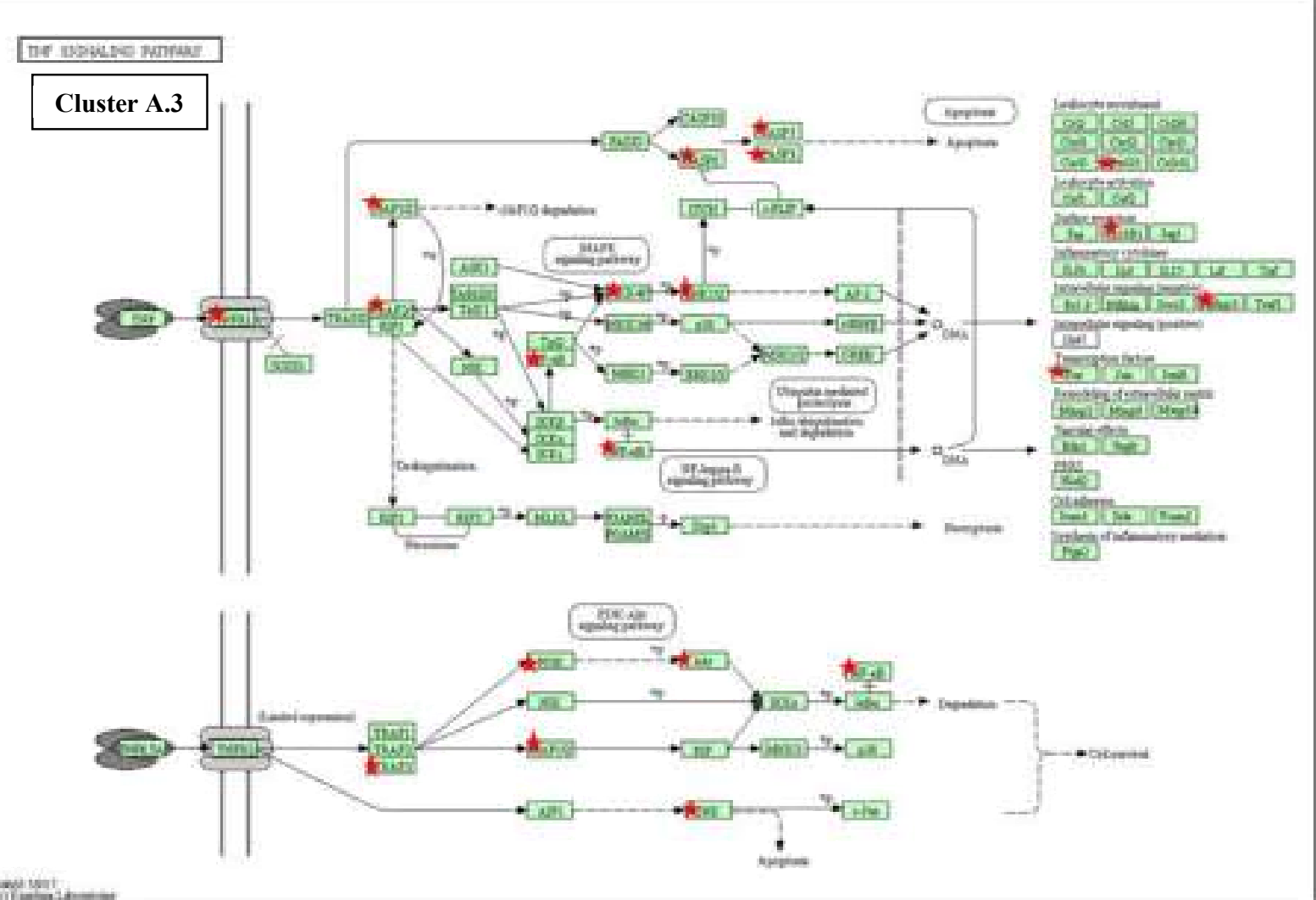

Figura S14. Representação da via de sinalização de TNF a partir da ferramenta DAVID com a análise dos genes alvos compartilhados entre os miRNAs do cluster A.3 (em NTera-2), onde os grupos de genes (associados por suas funções biológicas na via) marcados com as estrelas vermelhas são aqueles em que um ou mais alvos do cluster se encontram. 


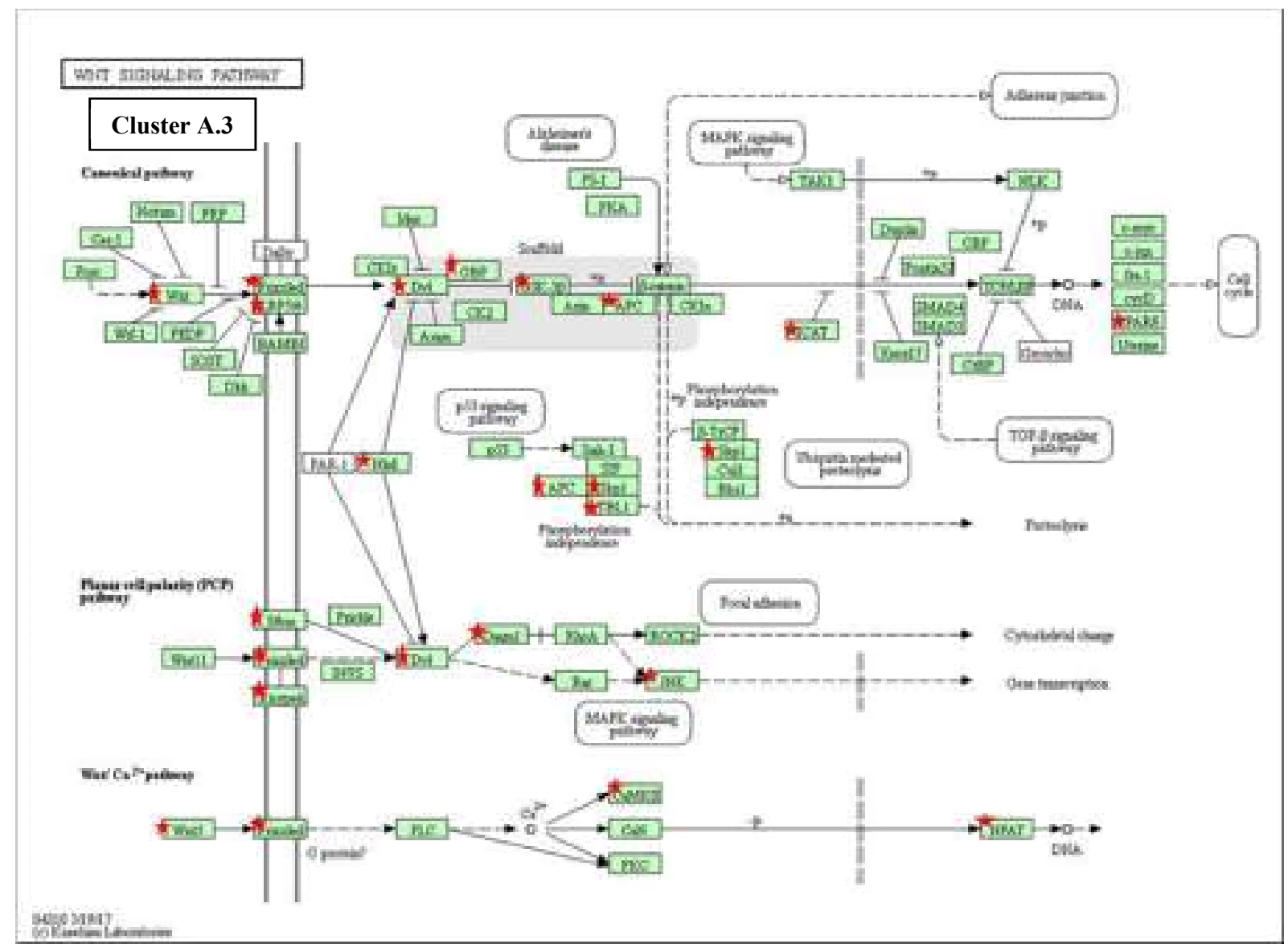

Figura S15. Representação da via de sinalização de WNT a partir da ferramenta DAVID com a análise dos genes alvos compartilhados entre os miRNAs do cluster A.3 (em NTera-2), onde os grupos de genes (associados por suas funções biológicas na via) marcados com as estrelas vermelhas são aqueles em que um ou mais alvos do cluster se encontram. 


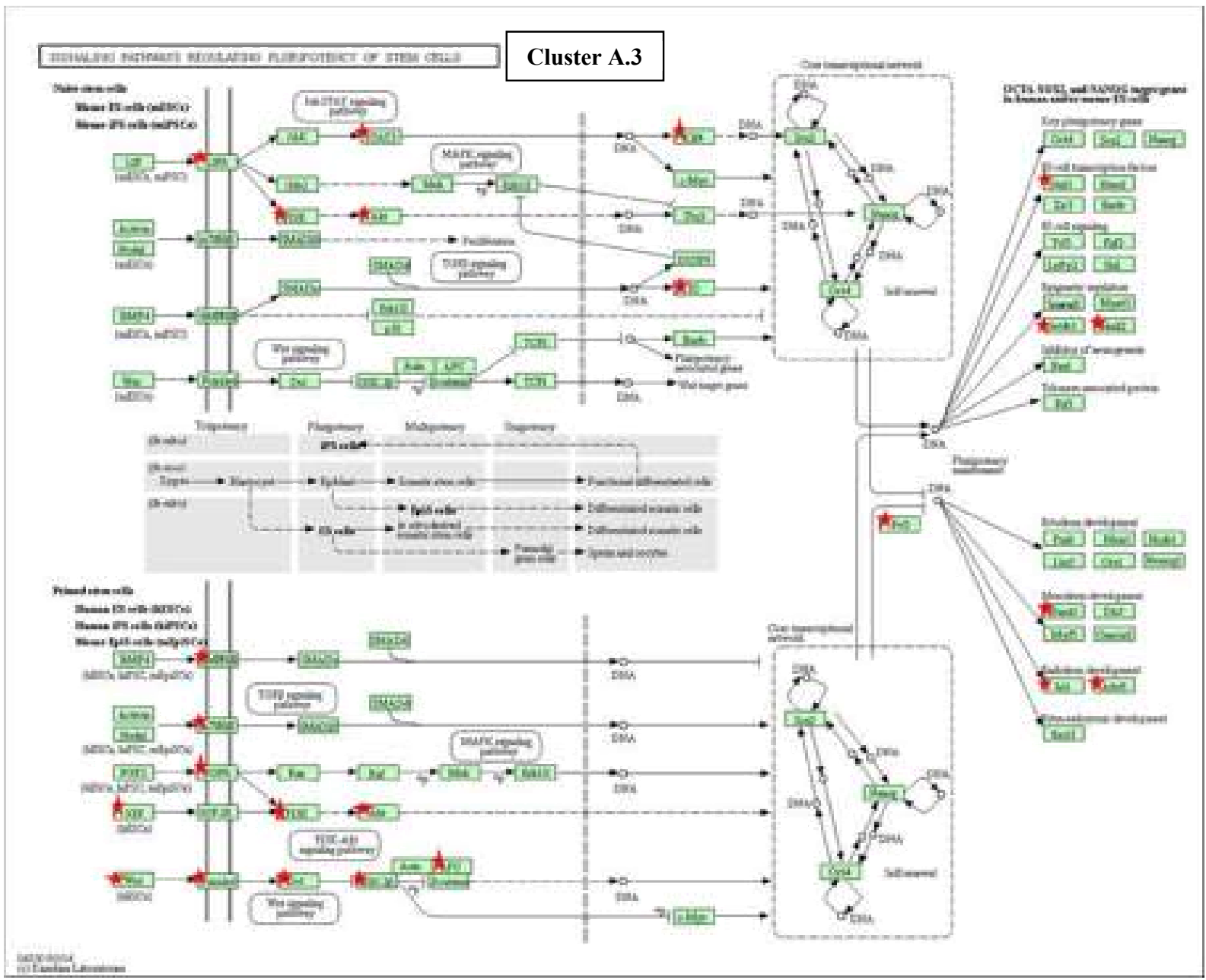

Figura S16. Representação das vias de sinalização regulando a pluripotência em células-tronco a partir da ferramenta DAVID com a análise dos genes alvos compartilhados entre os miRNAs do cluster A.3 (em NTera2), onde os grupos de genes (associados por suas funções biológicas na via) marcados com as estrelas vermelhas são aqueles em que um ou mais alvos do cluster se encontram. 


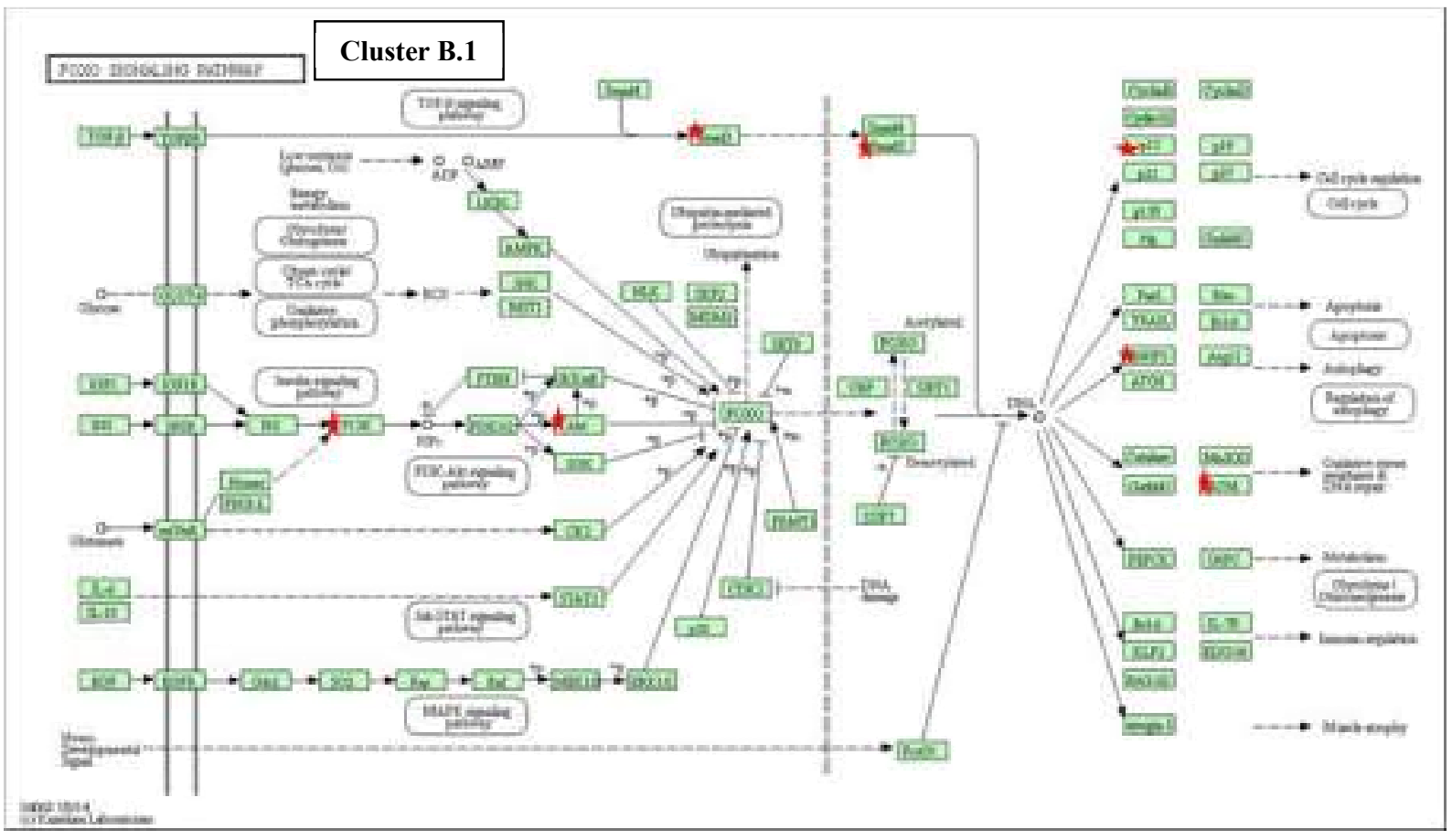

Figura S17. Representação da vias de sinalização de FOXO a partir da ferramenta DAVID com a análise dos genes alvos compartilhados entre os miRNAs do cluster B.1 (em NTera-2), onde os grupos de genes (associados por suas funções biológicas na via) marcados com as estrelas vermelhas são aqueles em que um ou mais alvos do cluster se encontram. 


\section{ANEXOS}

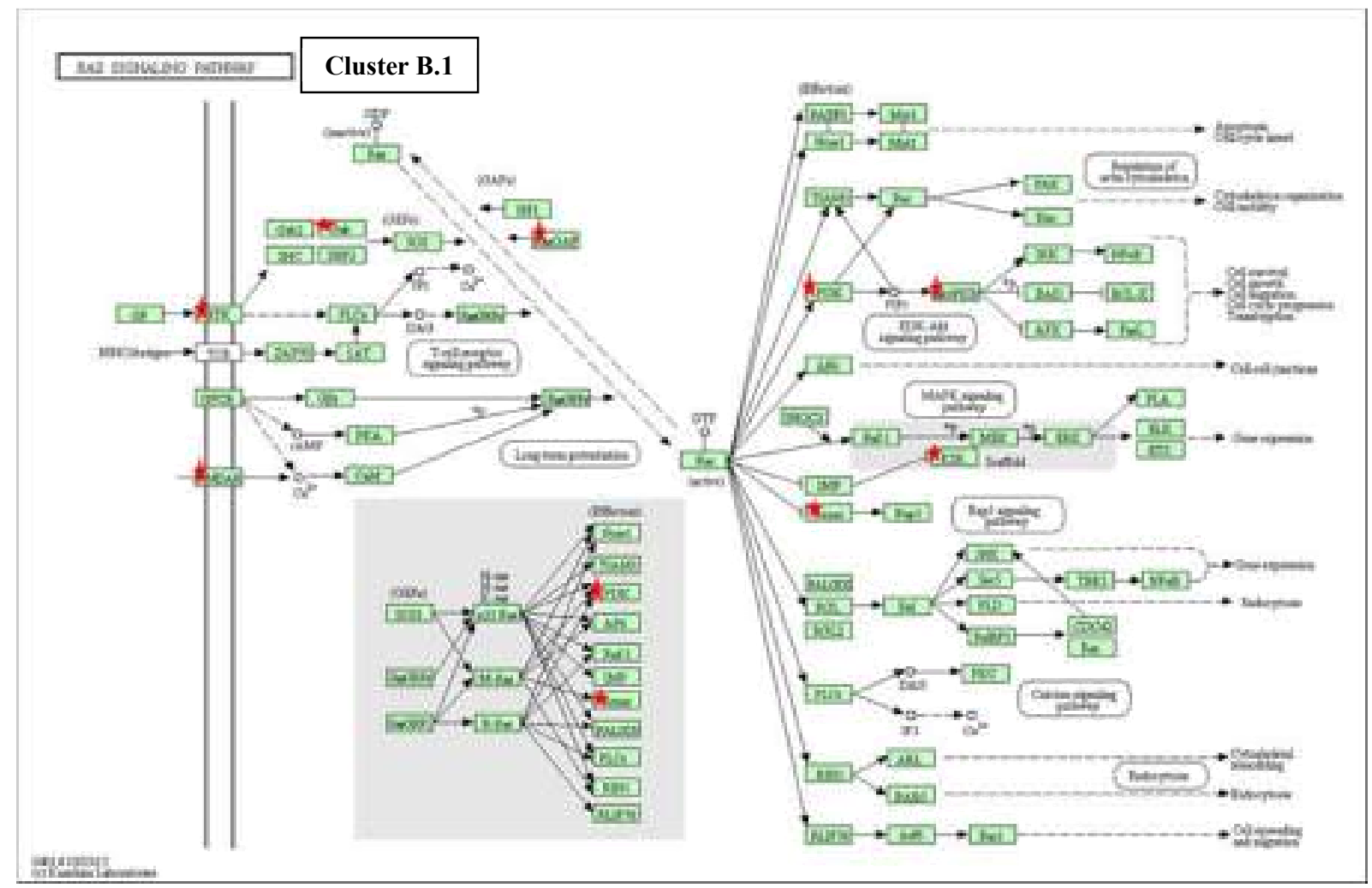

Figura S18. Representação da vias de sinalização de RAS a partir da ferramenta DAVID com a análise dos genes alvos compartilhados entre os miRNAs do cluster B.1 (em NTera-2), onde os grupos de genes (associados por suas funções biológicas na via) marcados com as estrelas vermelhas são aqueles em que um ou mais alvos do cluster se encontram. 
Cluster B.2a
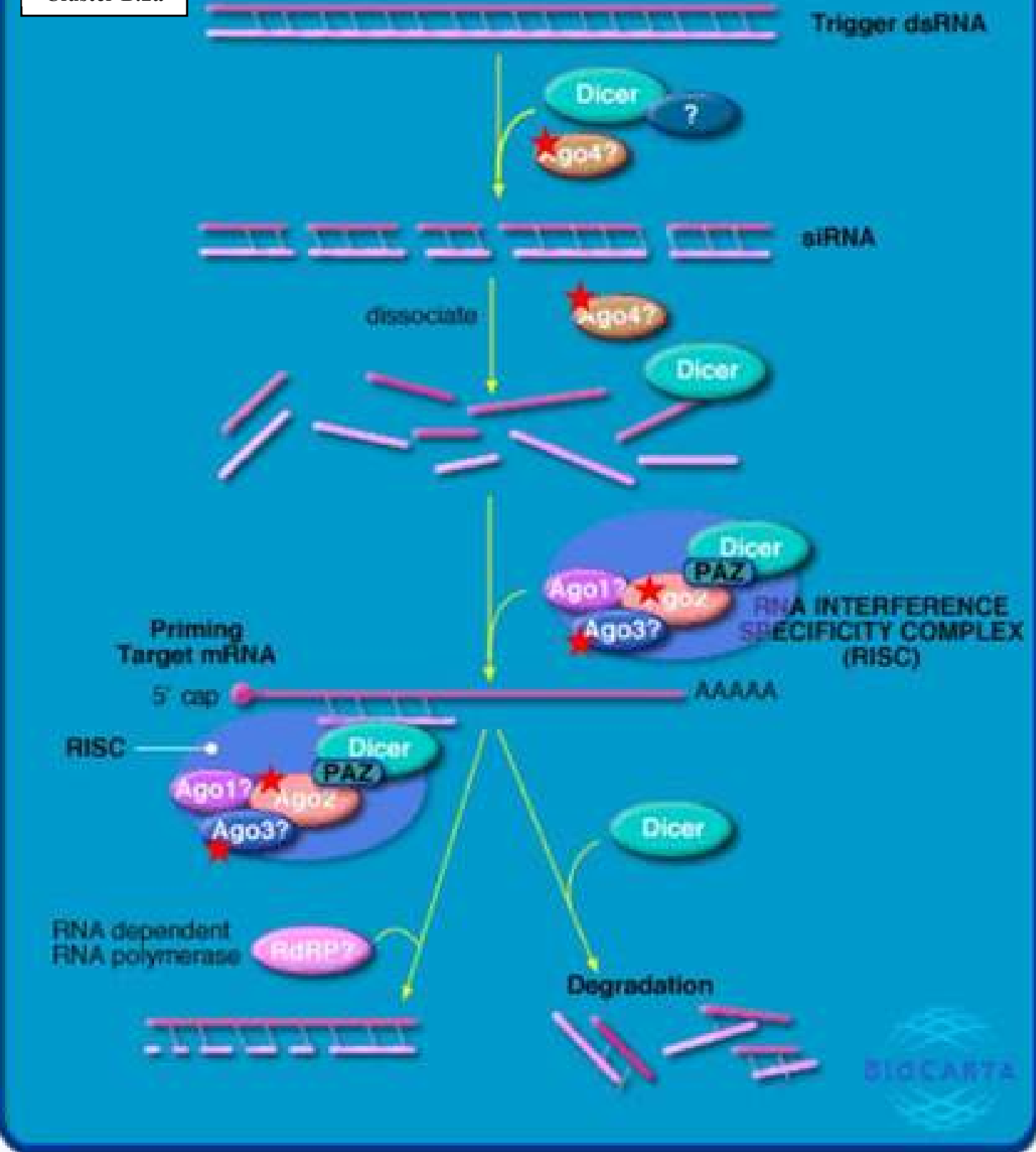

Figura S19. Representação da via de DICER a partir da ferramenta DAVID com a análise dos genes alvos compartilhados entre os miRNAs do cluster B.2a (em NTera-2), onde os grupos de genes (associados por suas funções biológicas na via) marcados com as estrelas vermelhas são aqueles em que um ou mais alvos do cluster se encontram. 


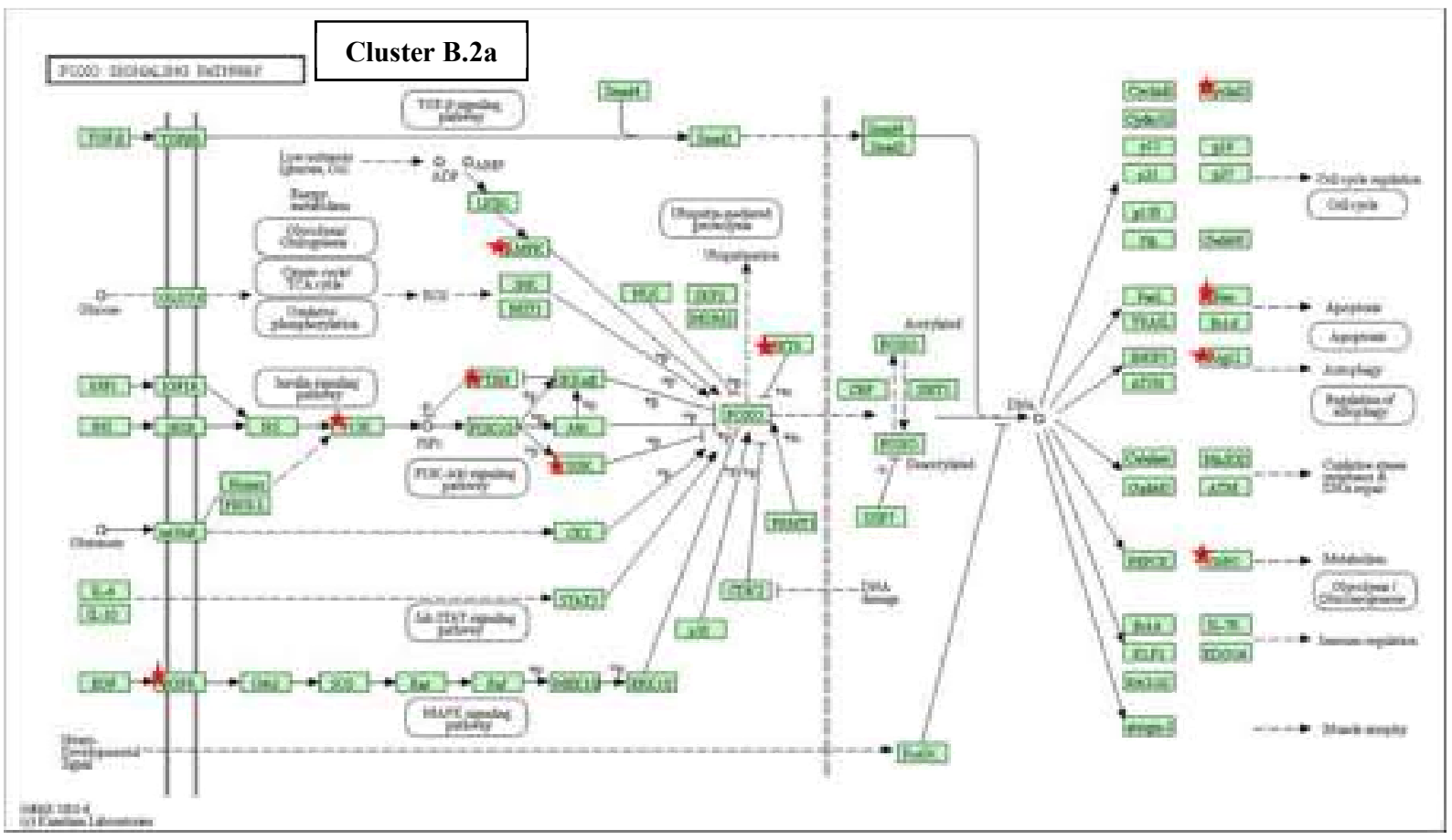

Figura S20. Representação da via de sinalização de FOXO a partir da ferramenta DAVID com a análise dos genes alvos compartilhados entre os miRNAs do cluster B.2a (em NTera-2), onde os grupos de genes (associados por suas funções biológicas na via) marcados com as estrelas vermelhas são aqueles em que um ou mais alvos do cluster se encontram. 


\section{ANEXOS}

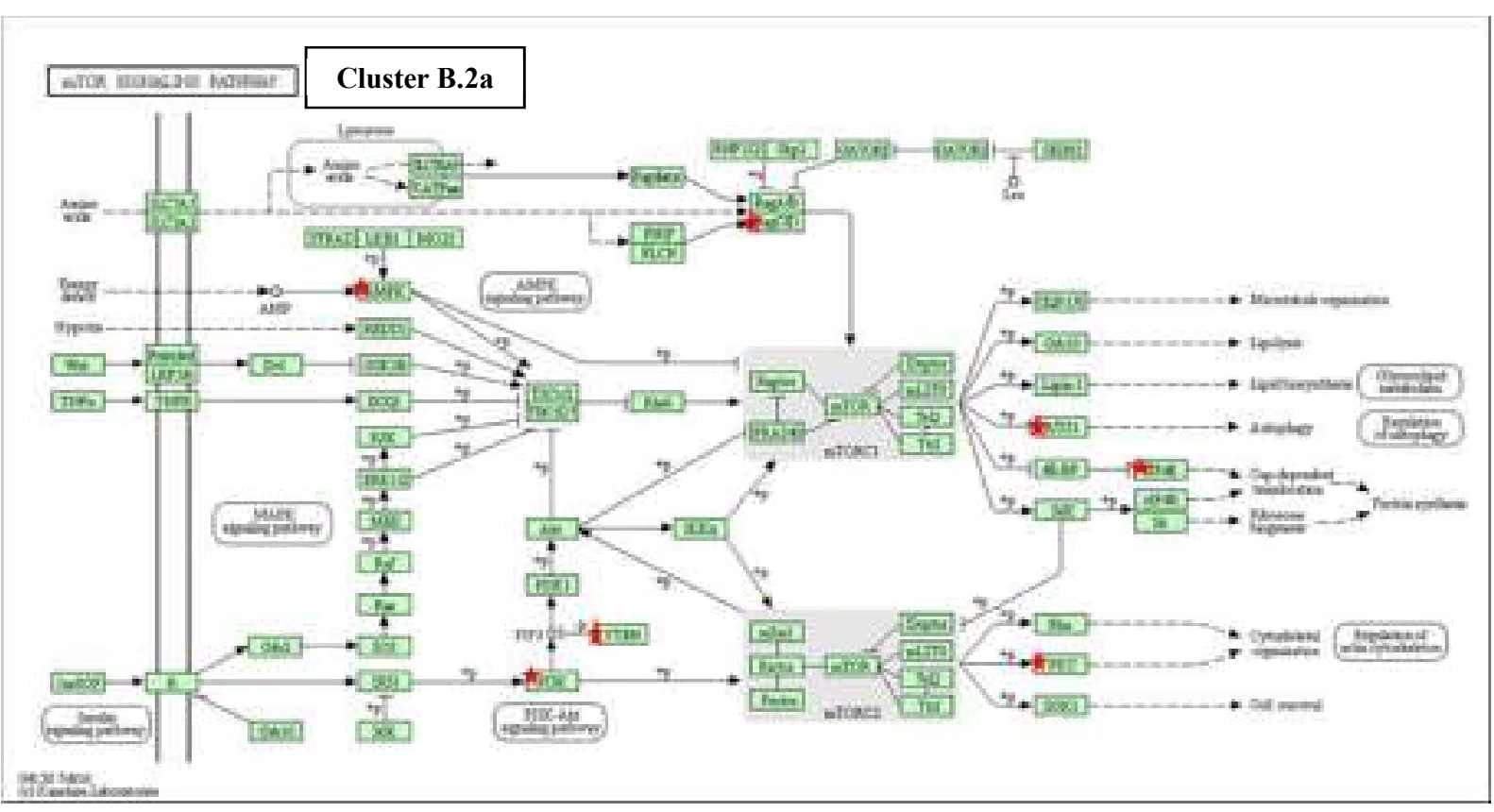

Figura S21. Representação da via de sinalização de mTOR a partir da ferramenta DAVID com a análise dos genes alvos compartilhados entre os miRNAs do cluster B.2a (em NTera-2), onde os grupos de genes (associados por suas funções biológicas na via) marcados com as estrelas vermelhas são aqueles em que um ou mais alvos do cluster se encontram. 


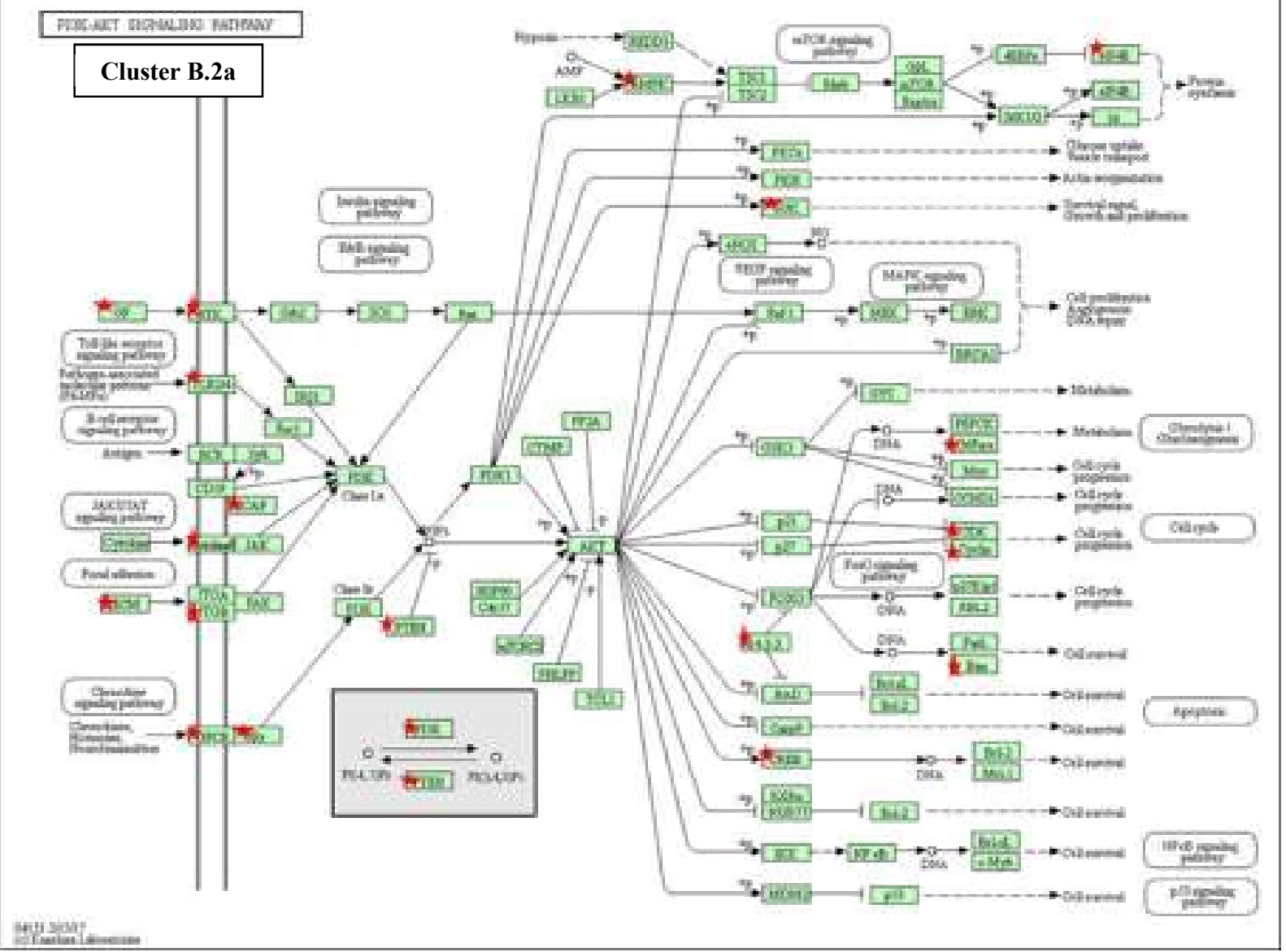

Figura S22. Representação da via de sinalização de PI3K-AKT a partir da ferramenta DAVID com a análise dos genes alvos compartilhados entre os miRNAs do cluster B.2a (em NTera-2), onde os grupos de genes (associados por suas funções biológicas na via) marcados com as estrelas vermelhas são aqueles em que um ou mais alvos do cluster se encontram. 


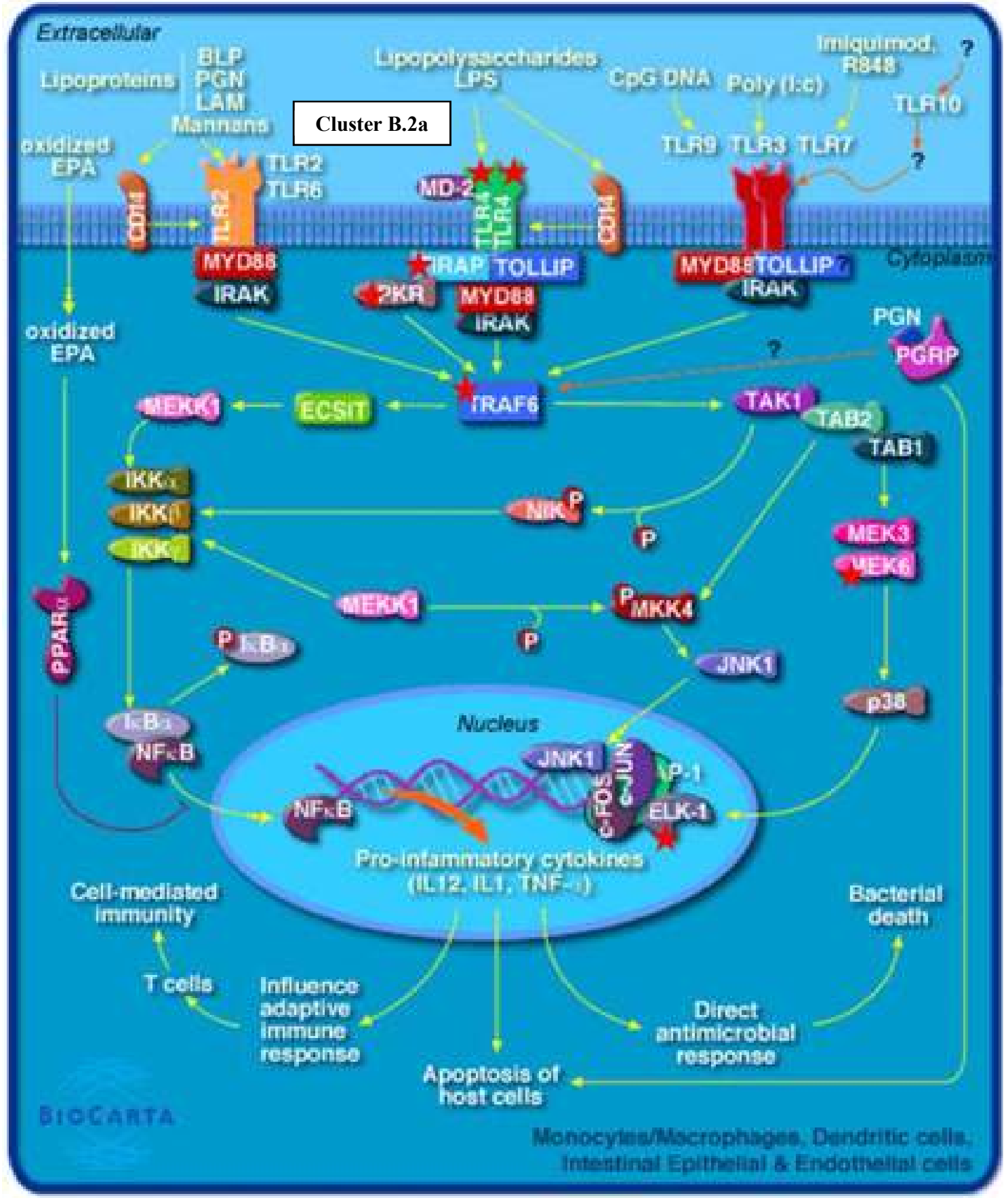

Figura S23. Representação da via de sinalização de Toll-like receptor a partir da ferramenta DAVID com a análise dos genes alvos compartilhados entre os miRNAs do cluster B.2a (em NTera-2), onde os grupos de genes (associados por suas funções biológicas na via) marcados com as estrelas vermelhas são aqueles em que um ou mais alvos do cluster se encontram. 


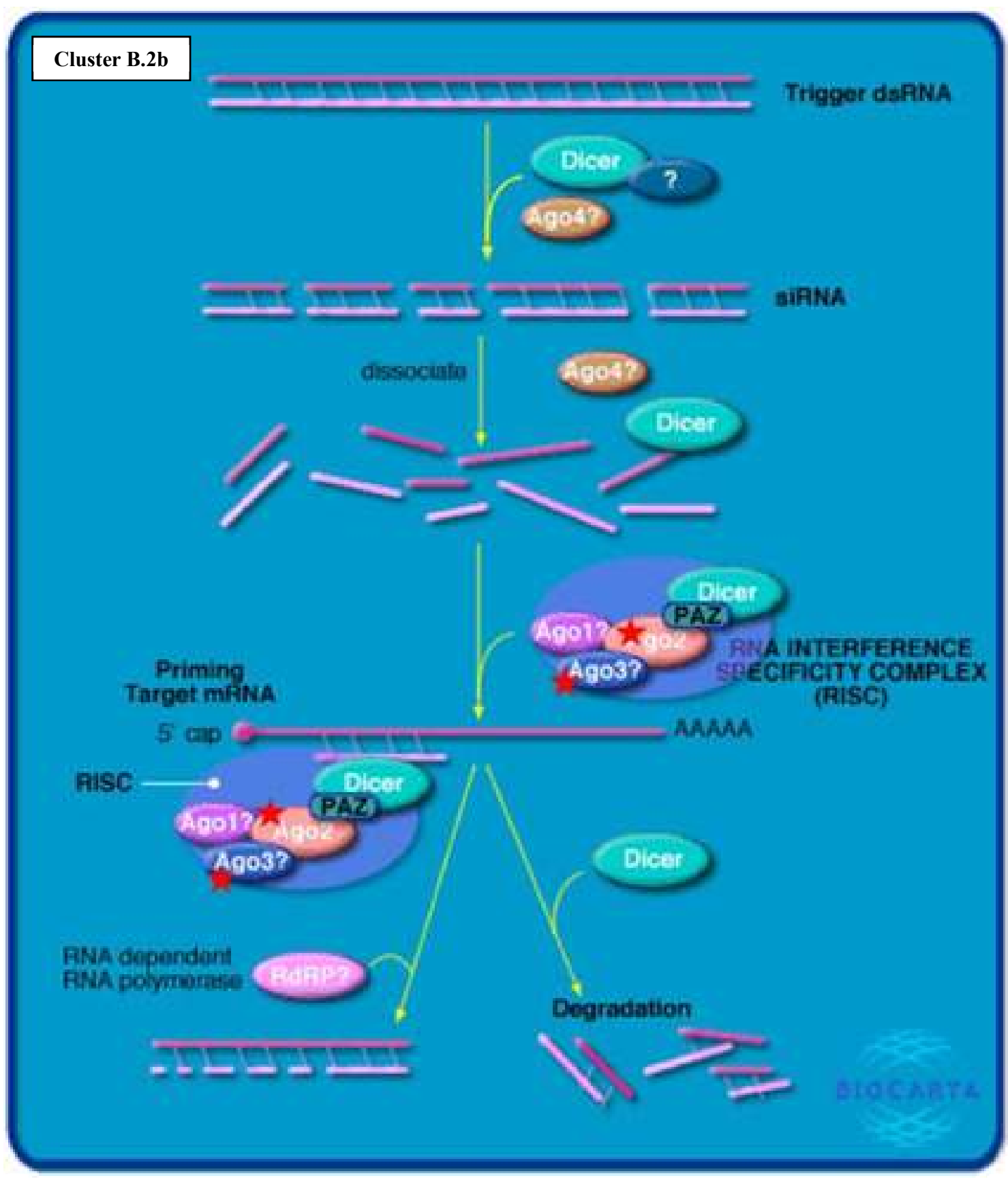

Figura S24. Representação da via de DICER a partir da ferramenta DAVID com a análise dos genes alvos compartilhados entre os miRNAs do cluster B.2b (em NTera-2), onde os grupos de genes (associados por suas funções biológicas na via) marcados com as estrelas vermelhas são aqueles em que um ou mais alvos do cluster se encontram. 


\section{ANEXOS}

ver moviseg perras.

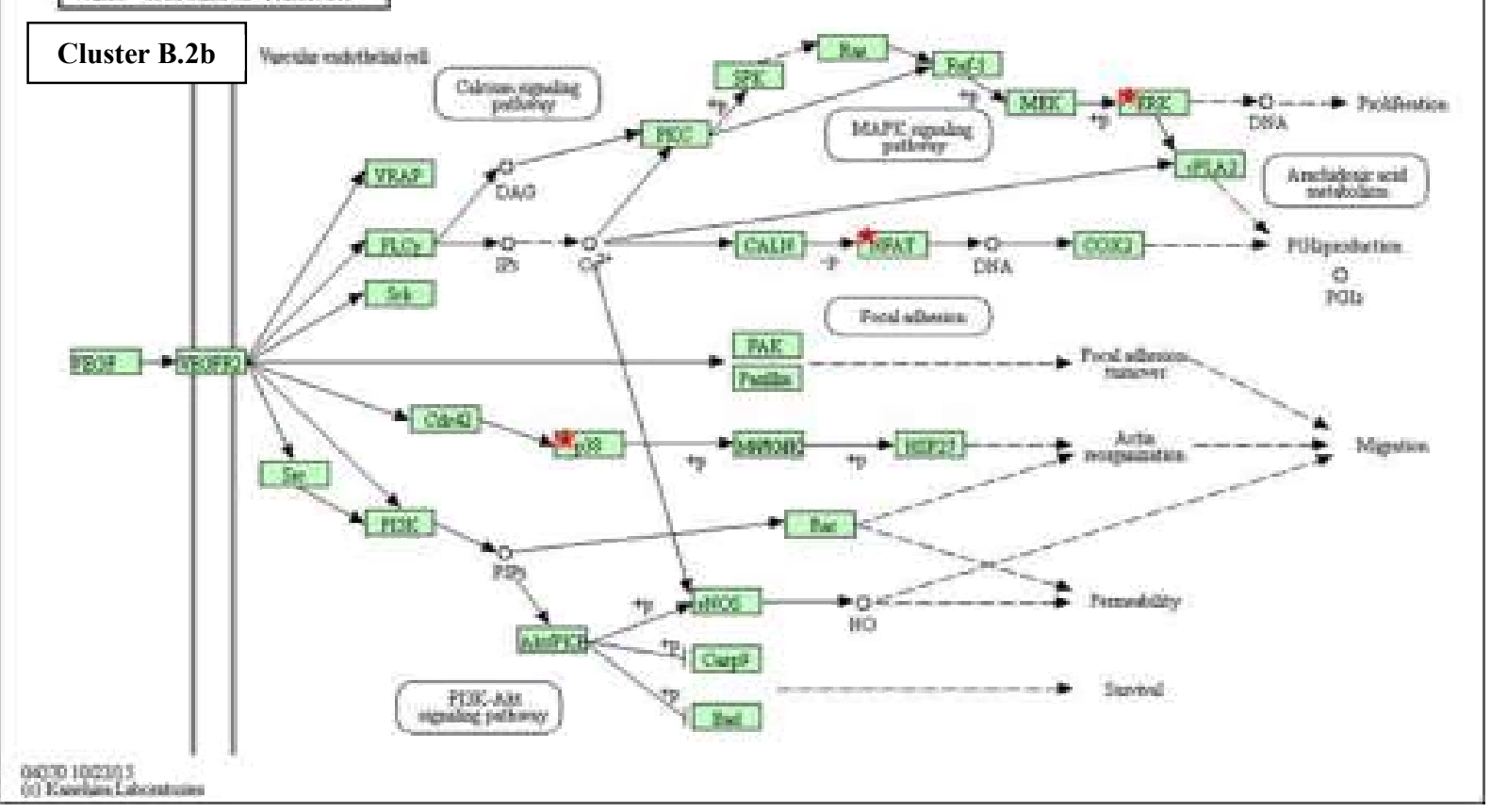

Figura S25. Representação da via de sinalização do VEGF a partir da ferramenta DAVID com a análise dos genes alvos compartilhados entre os miRNAs do cluster B.2b (em NTera-2), onde os grupos de genes (associados por suas funções biológicas na via) marcados com as estrelas vermelhas são aqueles em que um ou mais alvos do cluster se encontram. 


\section{ANEXOS}

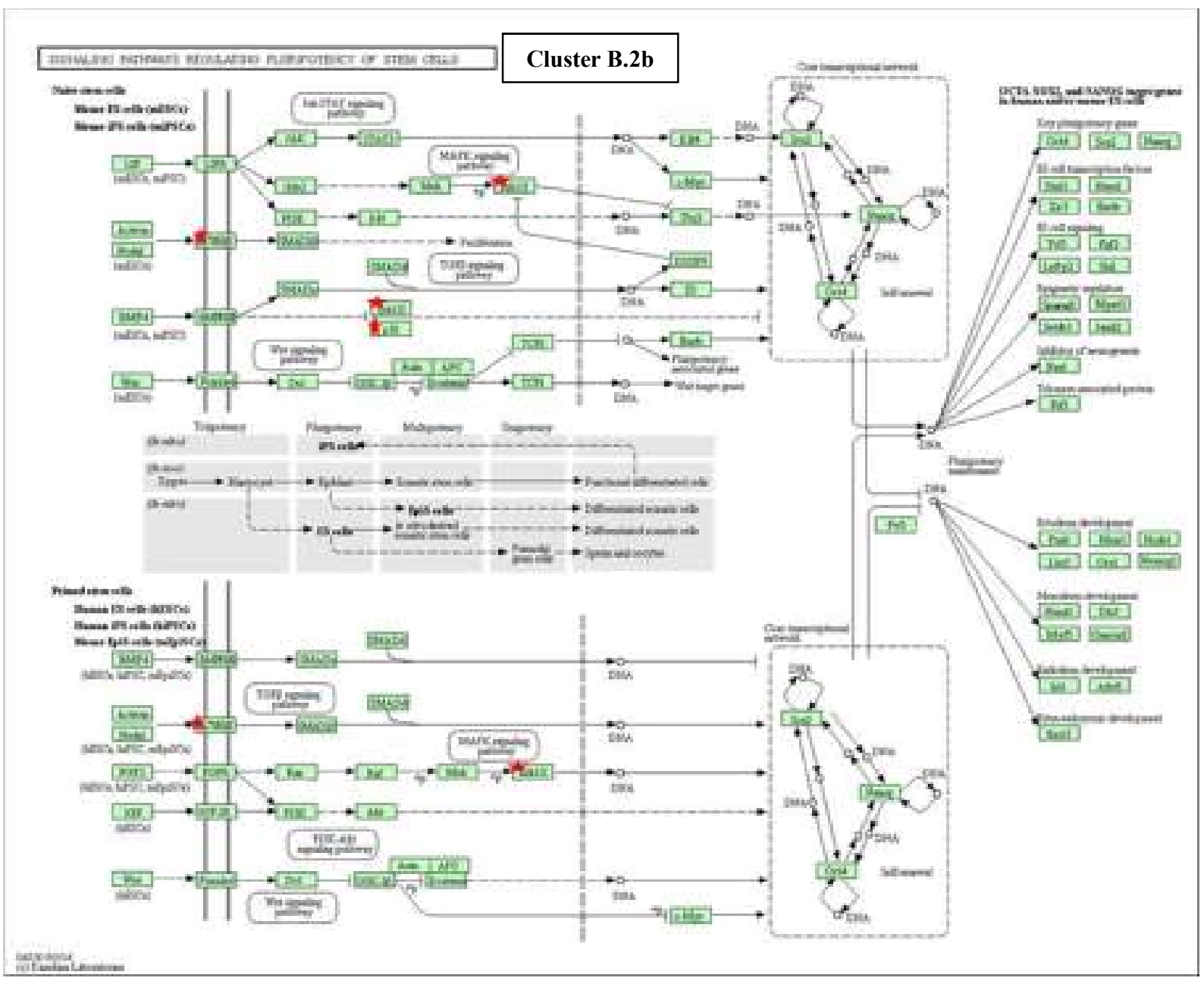

Figura S26. Representação das vias de sinalização regulando a pluripotência em células-tronco identificadas a partir da ferramenta DAVID com a análise dos genes alvos compartilhados entre os miRNAs do cluster B.2b (em NTera-2), onde os grupos de genes (associados por suas funções biológicas na via) marcados com as estrelas vermelhas são aqueles em que um ou mais alvos do cluster se encontram. 


\section{Anexo IV}

Aqui estão apresentadas as figuras das vias de sinalização identificadas por meio da ferramenta DAVID, utilizando-se os alvos compartilhados entre os miRNAs de cada cluster fenotípico observado na linhagem de célula-tronco embrionária H1.

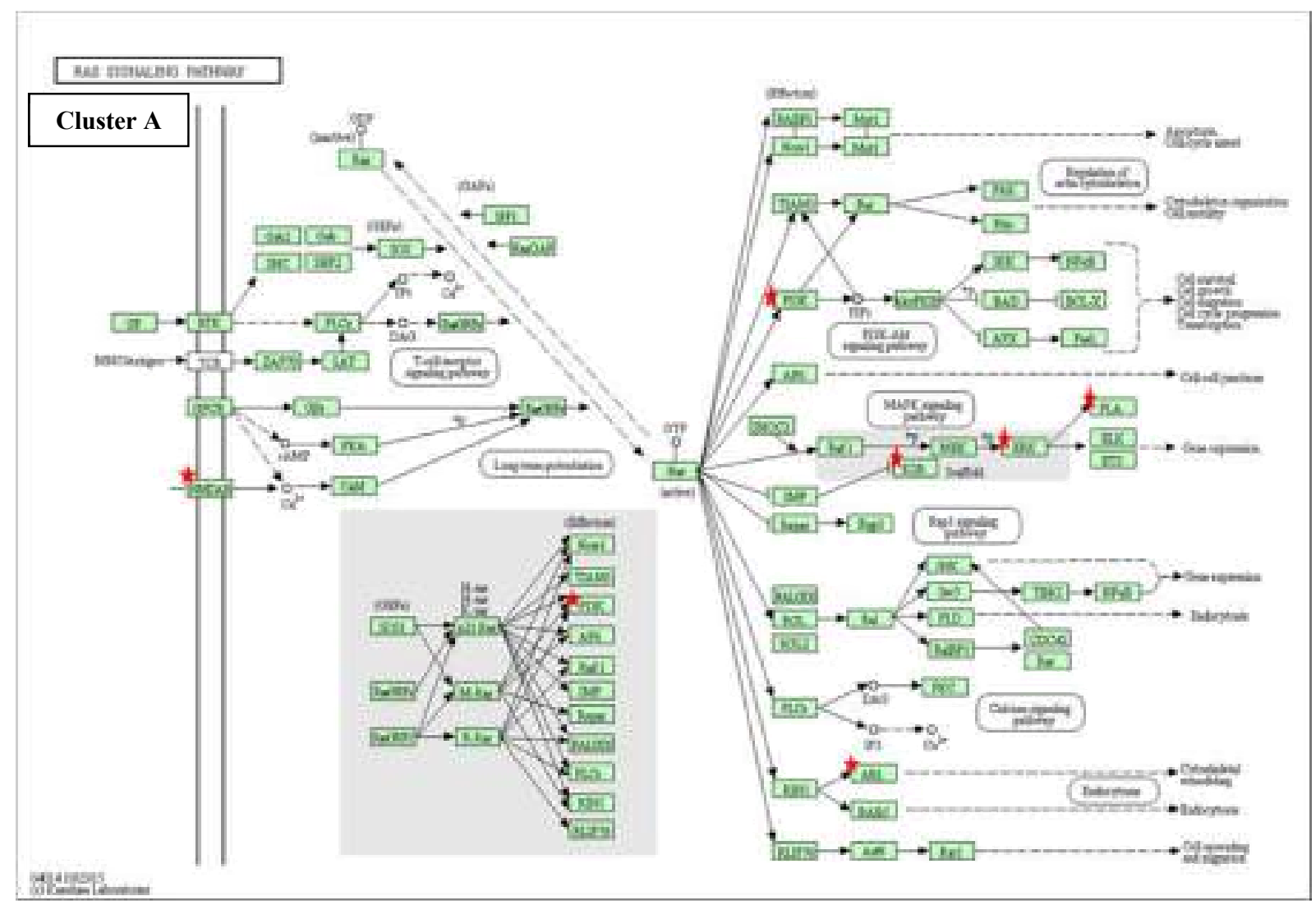

Figura S27. Representação da via de sinalização de RAS a partir da ferramenta DAVID com a análise dos genes alvos compartilhados entre os miRNAs do cluster A (em H1), onde os grupos de genes (associados por suas funções biológicas na via) marcados com as estrelas vermelhas são aqueles em que um ou mais alvos do cluster se encontram. 


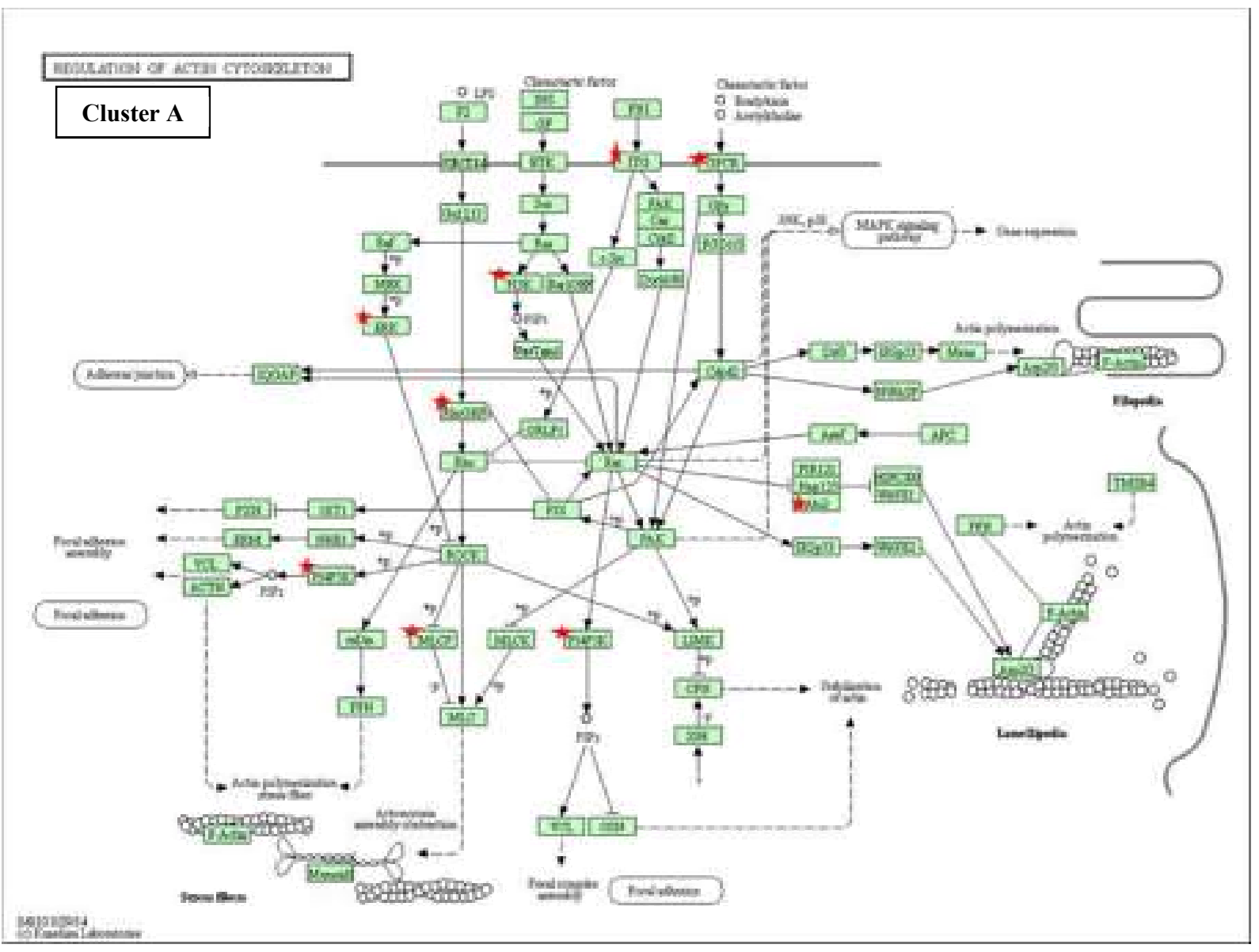

Figura S28. Representação da via de regulação do citoesqueleto de actina a partir da ferramenta DAVID com a análise dos genes alvos compartilhados entre os miRNAs do cluster A (em $\mathrm{H} 1)$, onde os grupos de genes (associados por suas funções biológicas na via) marcados com as estrelas vermelhas são aqueles em que um ou mais alvos do cluster se encontram. 


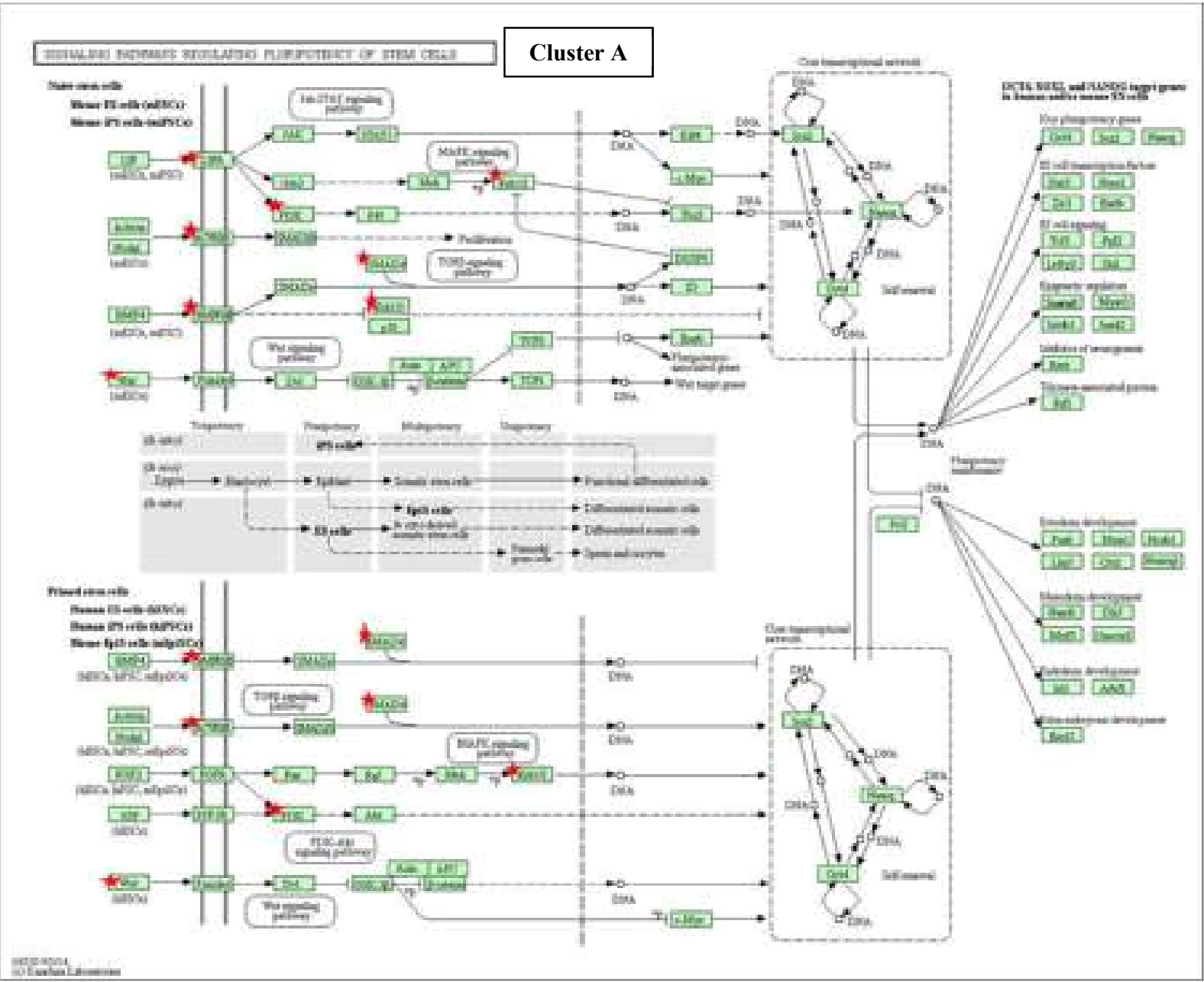

Figura S29. Representação das vias de sinalização regulando a pluripotência em células-tronco a partir da ferramenta DAVID com a análise dos genes alvos compartilhados entre os miRNAs do cluster A (em H1), onde os grupos de genes (associados por suas funções biológicas na via) marcados com as estrelas vermelhas são aqueles em que um ou mais alvos do cluster se encontram. 


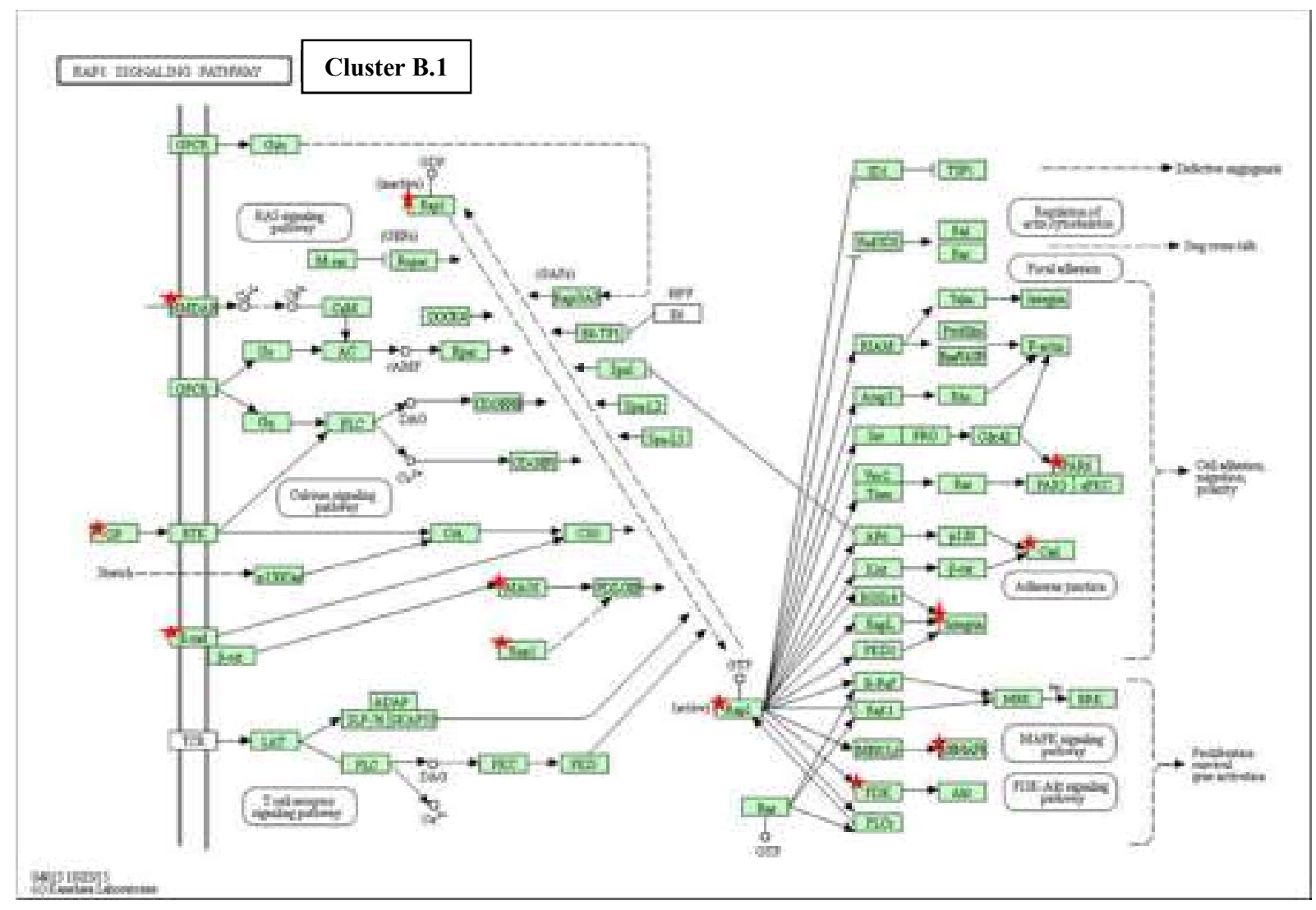

Figura S30. Representação da via de sinalização de RAP1 a partir da ferramenta DAVID com a análise dos genes alvos compartilhados entre os miRNAs do cluster B.1 (em H1), onde os grupos de genes (associados por suas funções biológicas na via) marcados com as estrelas vermelhas são aqueles em que um ou mais alvos do cluster se encontram. 


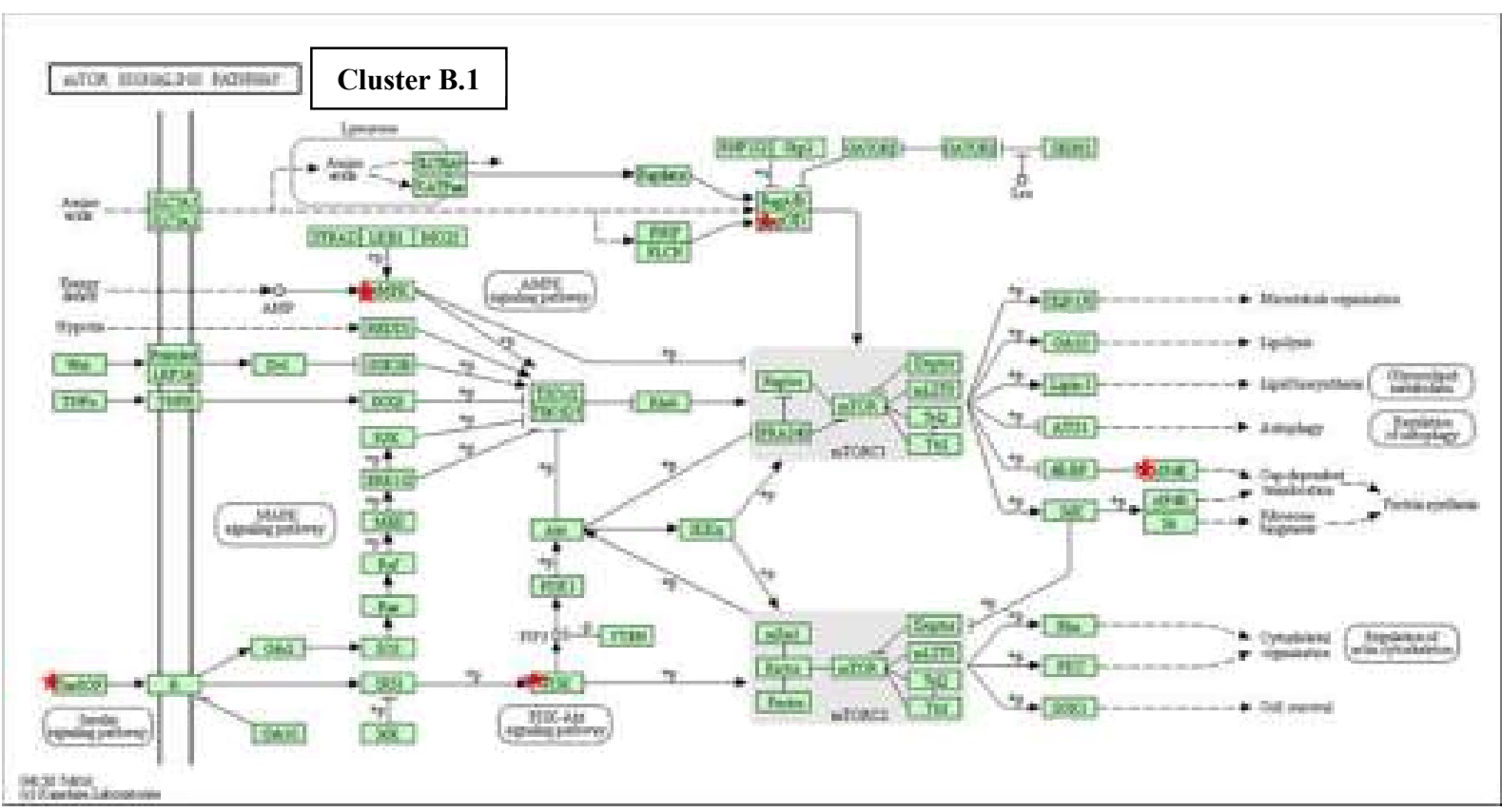

Figura S31. Representação da via de sinalização de mTOR a partir da ferramenta DAVID com a análise dos genes alvos compartilhados entre os miRNAs do cluster B.1 (em H1), onde os grupos de genes (associados por suas funções biológicas na via) marcados com as estrelas vermelhas são aqueles em que um ou mais alvos do cluster se encontram. 


\section{ANEXOS}

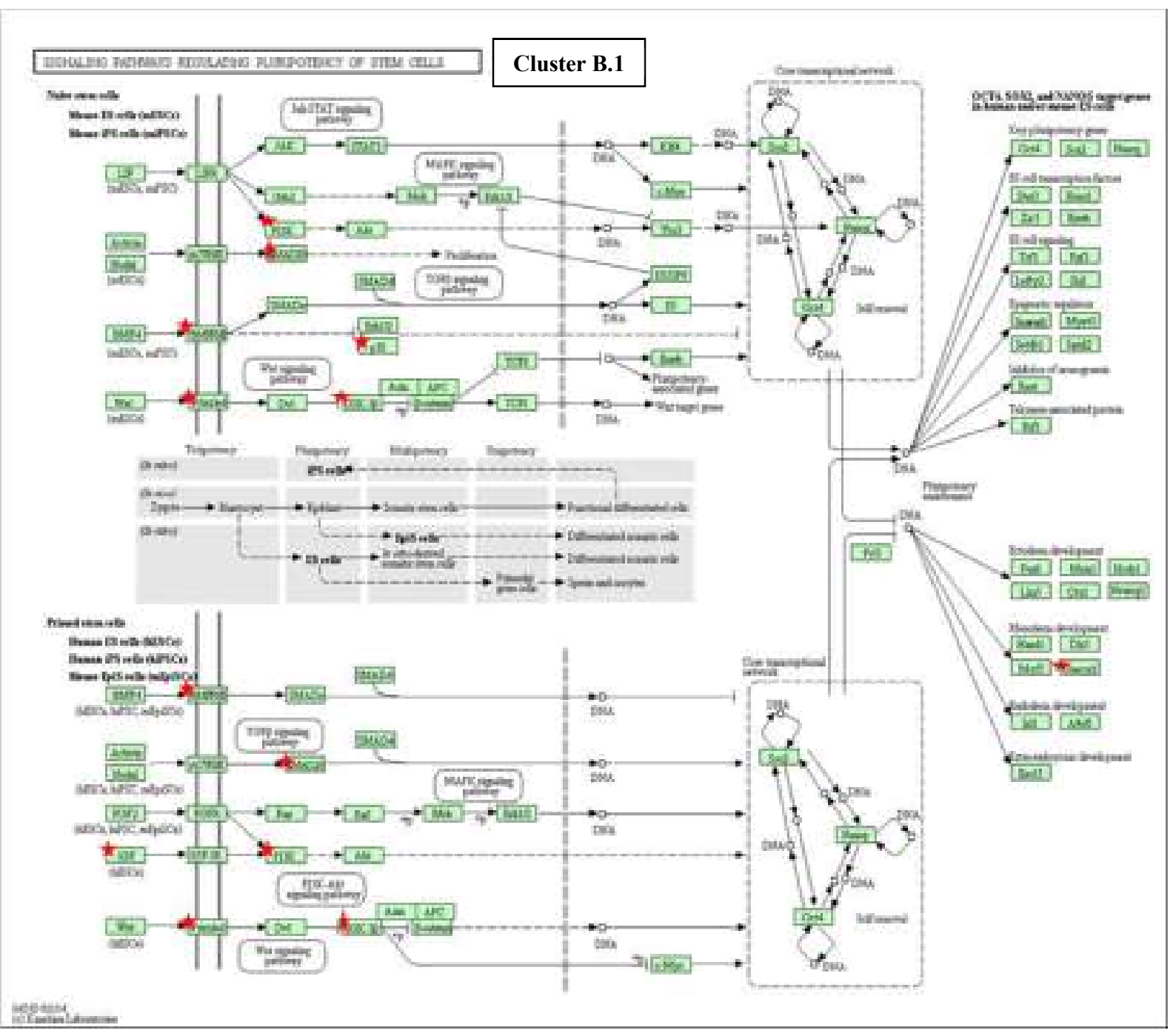

Figura S32. Representação das vias de sinalização regulando a pluripotência em células-tronco a partir da ferramenta DAVID com a análise dos genes alvos compartilhados entre os miRNAs do cluster B.1 (em H1), onde os grupos de genes (associados por suas funções biológicas na via) marcados com as estrelas vermelhas são aqueles em que um ou mais alvos do cluster se encontram. 


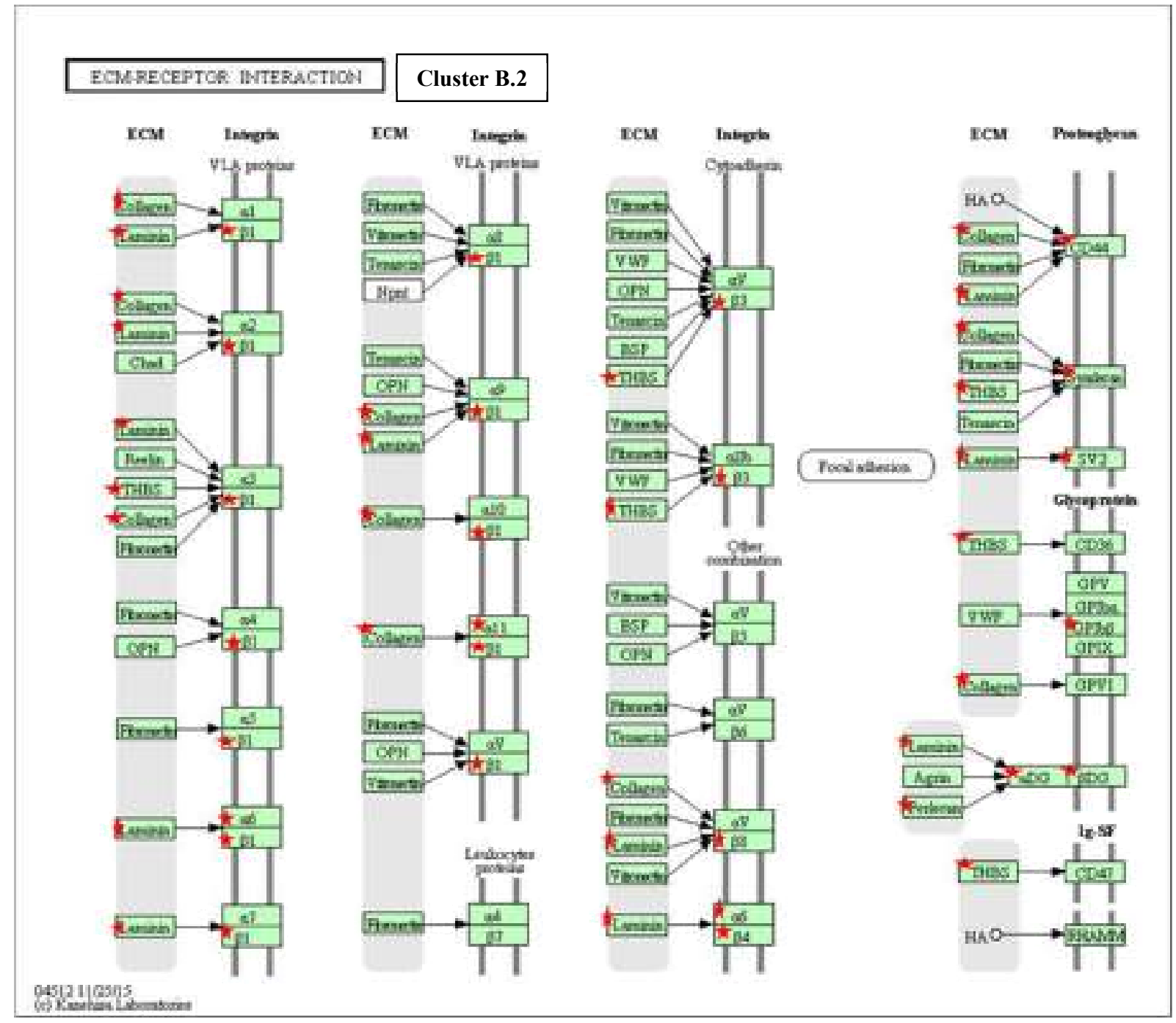

Figura S33. Representação da via de receptores de matriz extracelular a partir da ferramenta DAVID com a análise dos genes alvos compartilhados entre os miRNAs do cluster B.2 (em H1), onde os grupos de genes (associados por suas funções biológicas na via) marcados com as estrelas vermelhas são aqueles em que um ou mais alvos do cluster se encontram. 


\section{rock icresion}

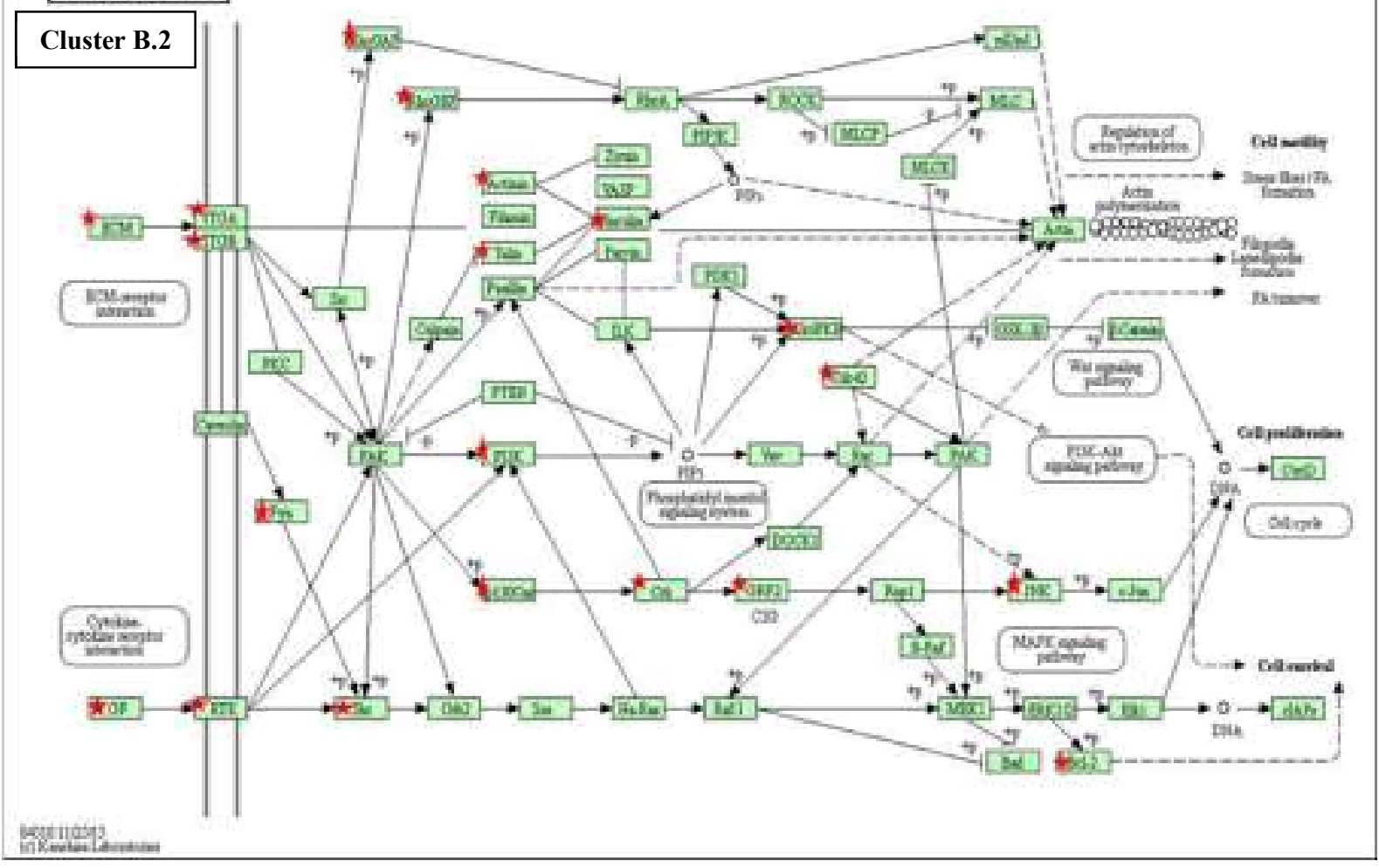

Figura S34. Representação da via de adesão focal a partir da ferramenta DAVID com a análise dos genes alvos compartilhados entre os miRNAs do cluster B.2 (em H1), onde os grupos de genes (associados por suas funções biológicas na via) marcados com as estrelas vermelhas são aqueles em que um ou mais alvos do cluster se encontram. 


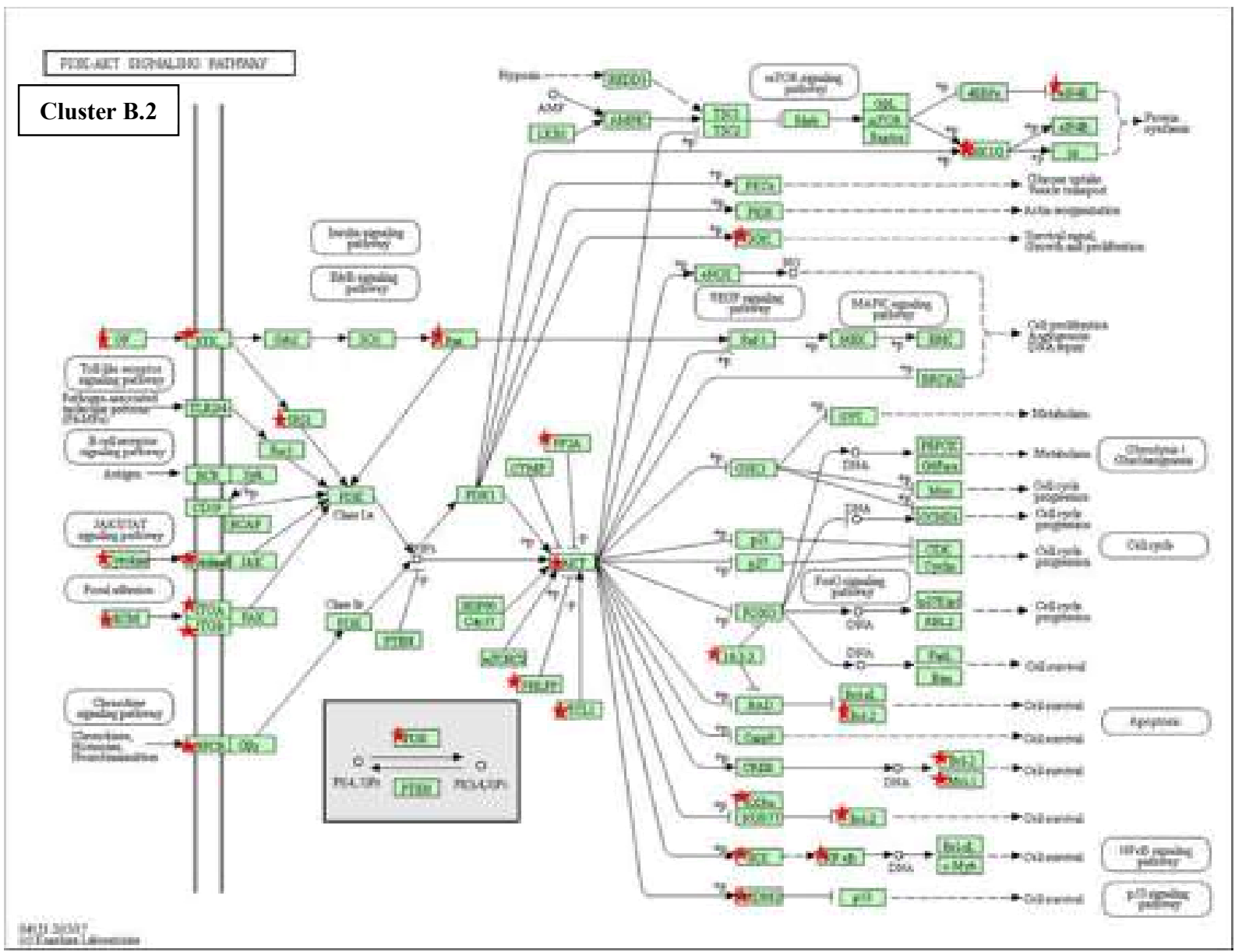

Figura S35. Representação da via de sinalização PI3K-AKT a partir da ferramenta DAVID com a análise dos genes alvos compartilhados entre os miRNAs do cluster B.2 (em H1), onde os grupos de genes (associados por suas funções biológicas na via) marcados com as estrelas vermelhas são aqueles em que um ou mais alvos do cluster se encontram. 


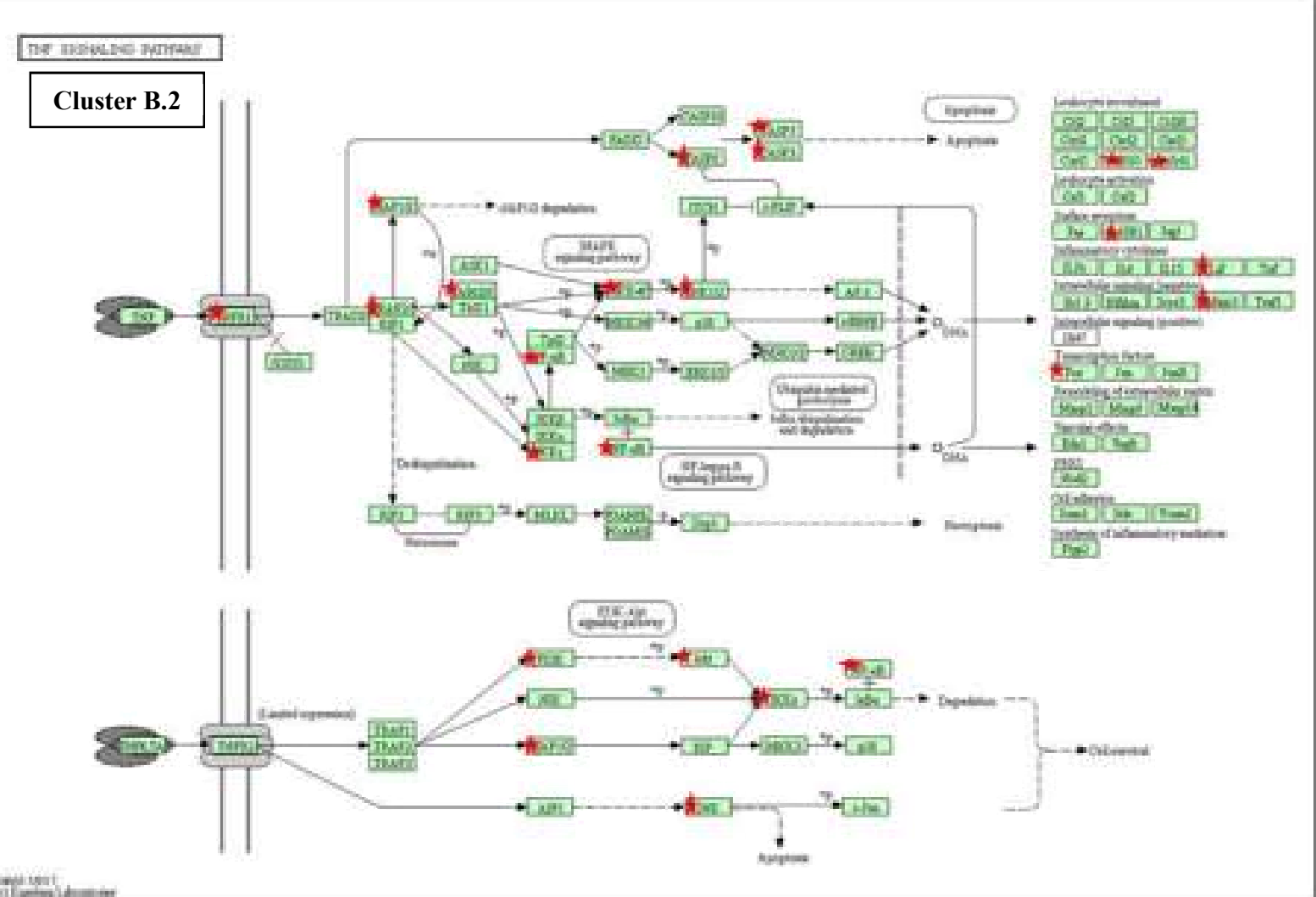

Figura S36. Representação da via de sinalização de TNF a partir da ferramenta DAVID com a análise dos genes alvos compartilhados entre os miRNAs do cluster B.2 (em H1), onde os grupos de genes (associados por suas funções biológicas na via) marcados com as estrelas vermelhas são aqueles em que um ou mais alvos do cluster se encontram. 


\section{ANEXOS}

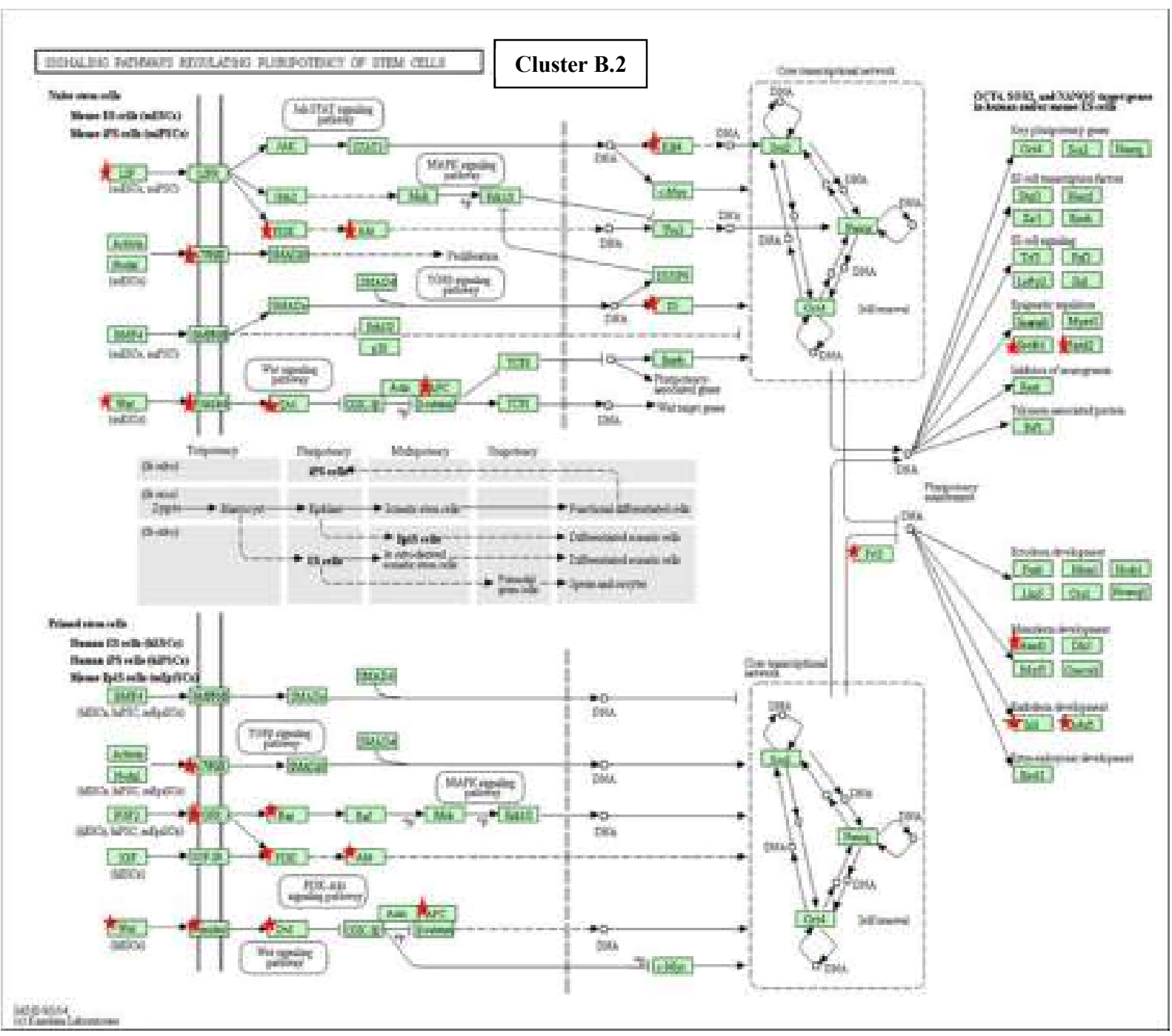

Figura S37. Representação das vias de sinalização regulando a pluripotência em células-tronco a partir da ferramenta DAVID com a análise dos genes alvos compartilhados entre os miRNAs do cluster B.2 (em H1), onde os grupos de genes (associados por suas funções biológicas na via) marcados com as estrelas vermelhas são aqueles em que um ou mais alvos do cluster se encontram. 


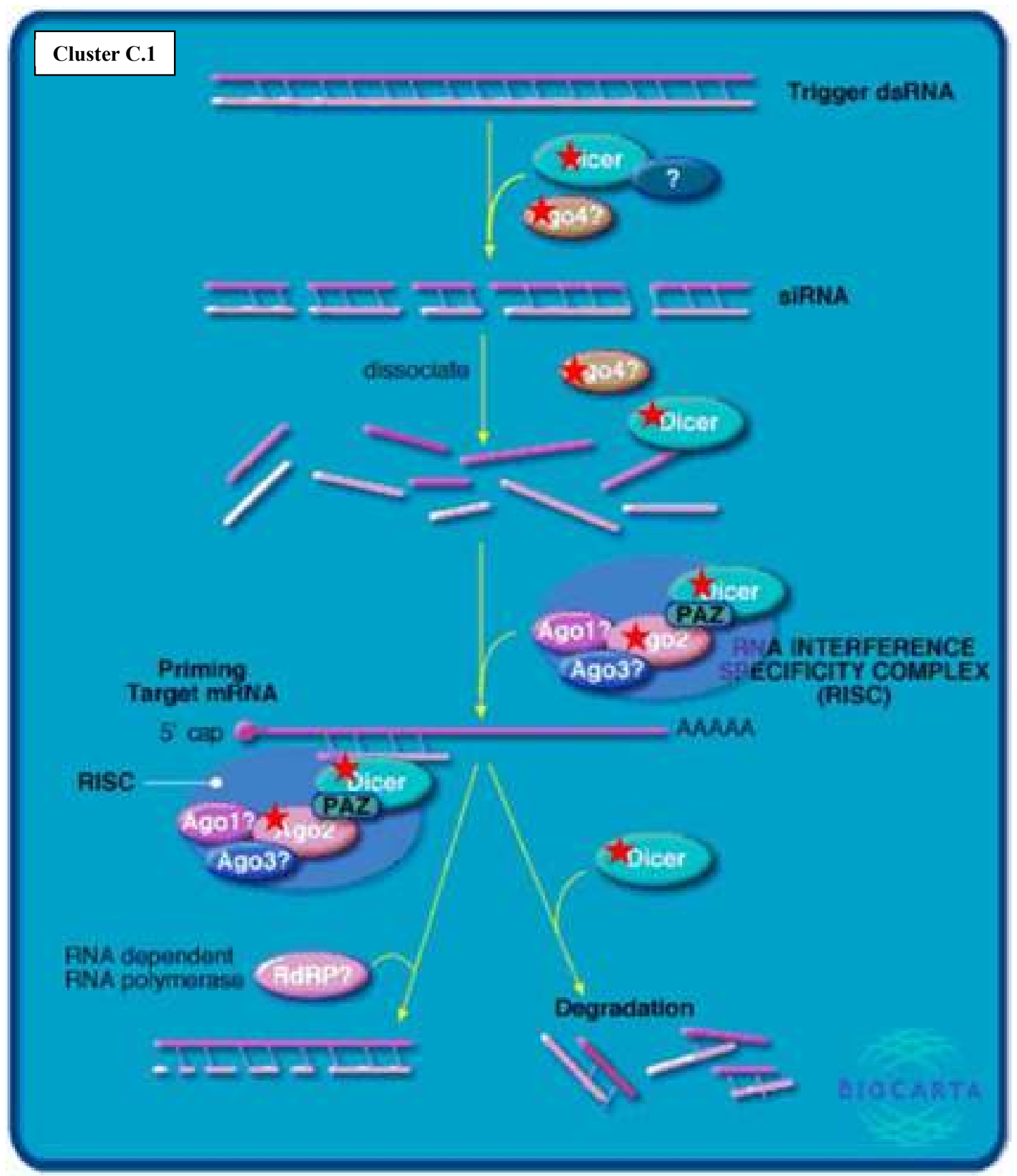

Figura S38. Representação da via de DICER a partir da ferramenta DAVID com a análise dos genes alvos compartilhados entre os miRNAs do cluster C.1 (em H1), onde os grupos de genes (associados por suas funções biológicas na via) marcados com as estrelas vermelhas são aqueles em que um ou mais alvos do cluster se encontram. 


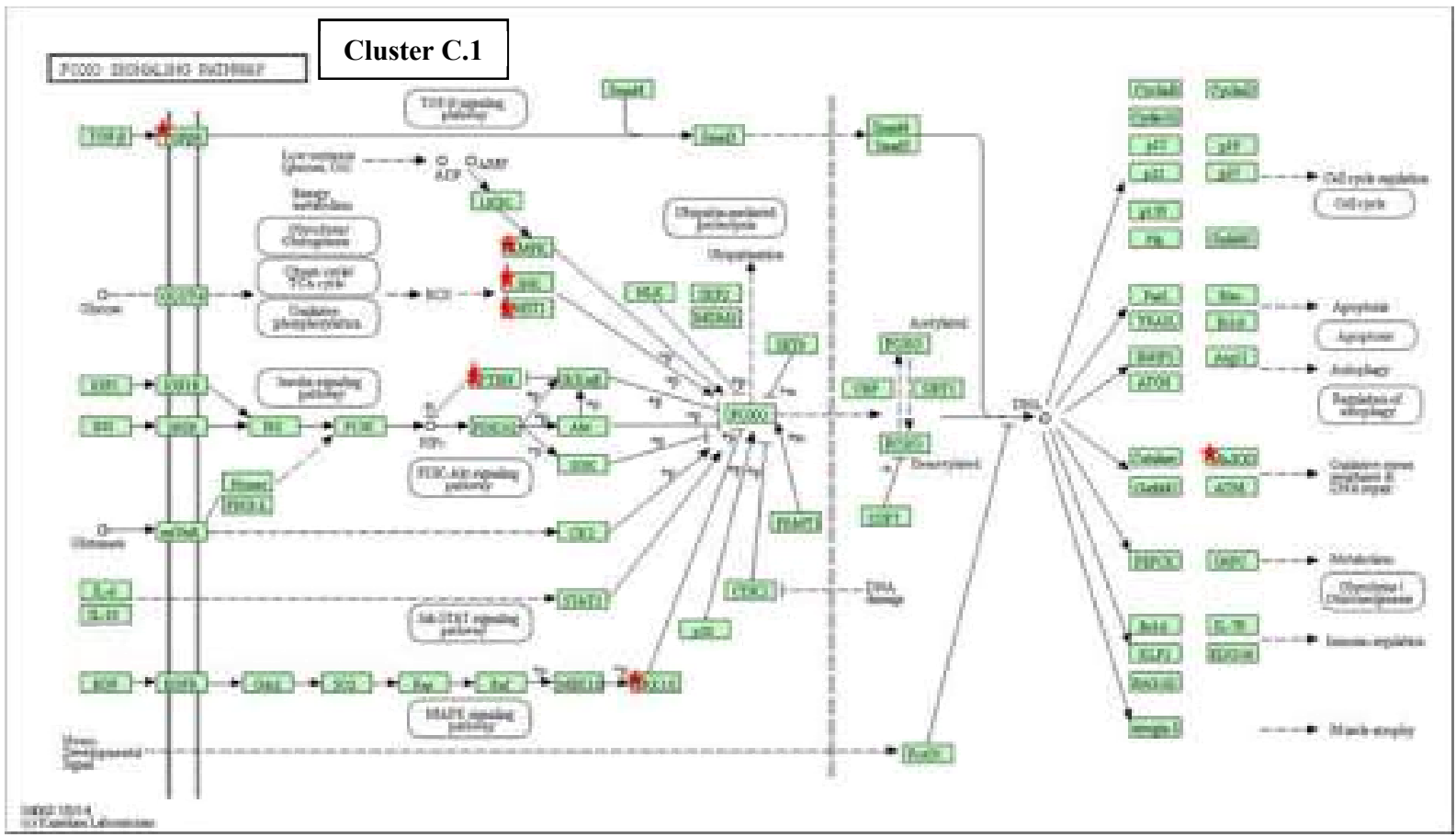

Figura S39. Representação da via de sinalização de FOXO a partir da ferramenta DAVID com a análise dos genes alvos compartilhados entre os miRNAs do cluster C.1 (em H1), onde os grupos de genes (associados por suas funções biológicas na via) marcados com as estrelas vermelhas são aqueles em que um ou mais alvos do cluster se encontram. 


\section{ANEXOS}

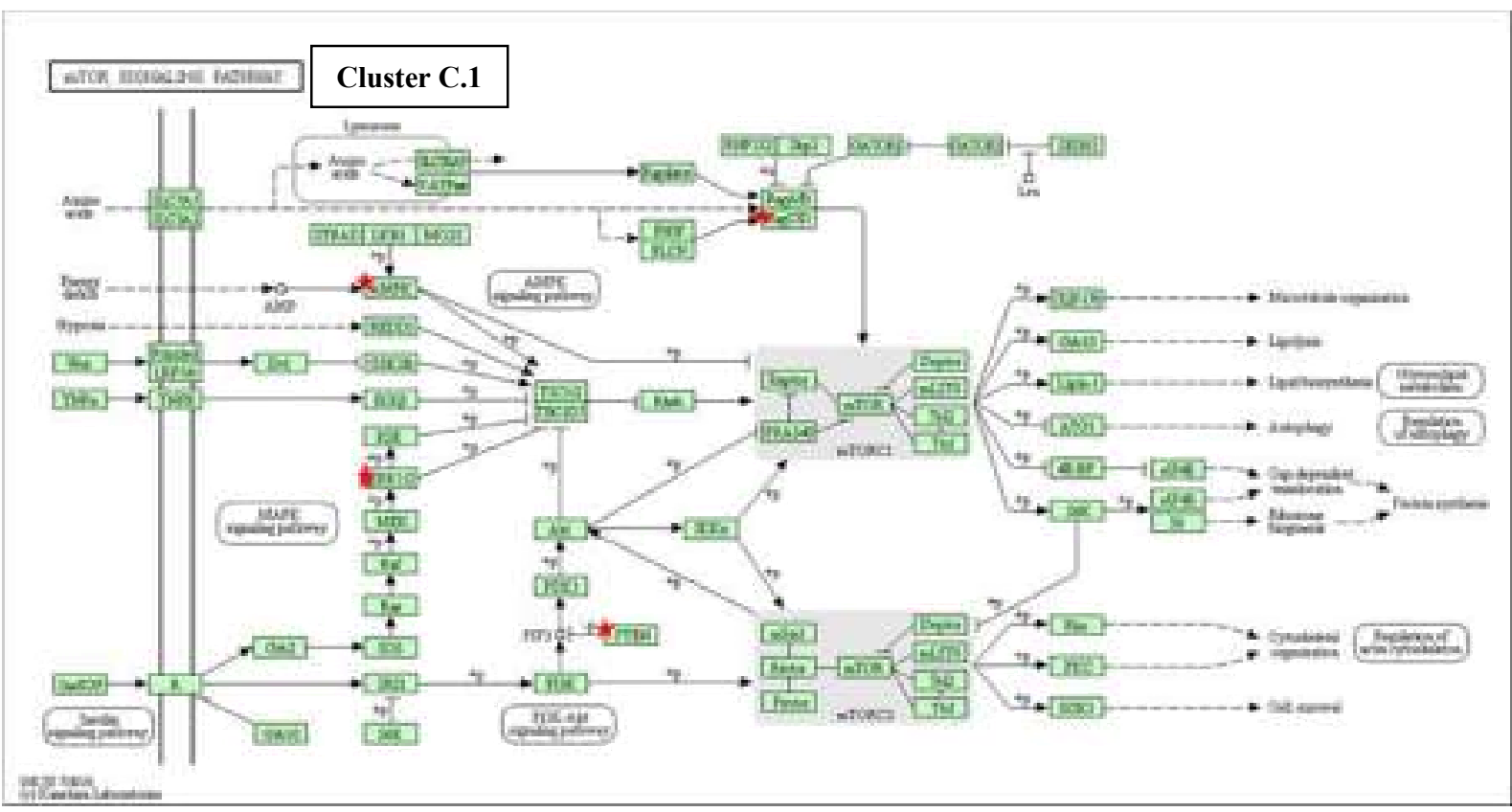

Figura S40. Representação da via de sinalização de mTOR a partir da ferramenta DAVID com a análise dos genes alvos compartilhados entre os miRNAs do cluster C.1 (em H1), onde os grupos de genes (associados por suas funções biológicas na via) marcados com as estrelas vermelhas são aqueles em que um ou mais alvos do cluster se encontram. 


\section{ANEXOS}

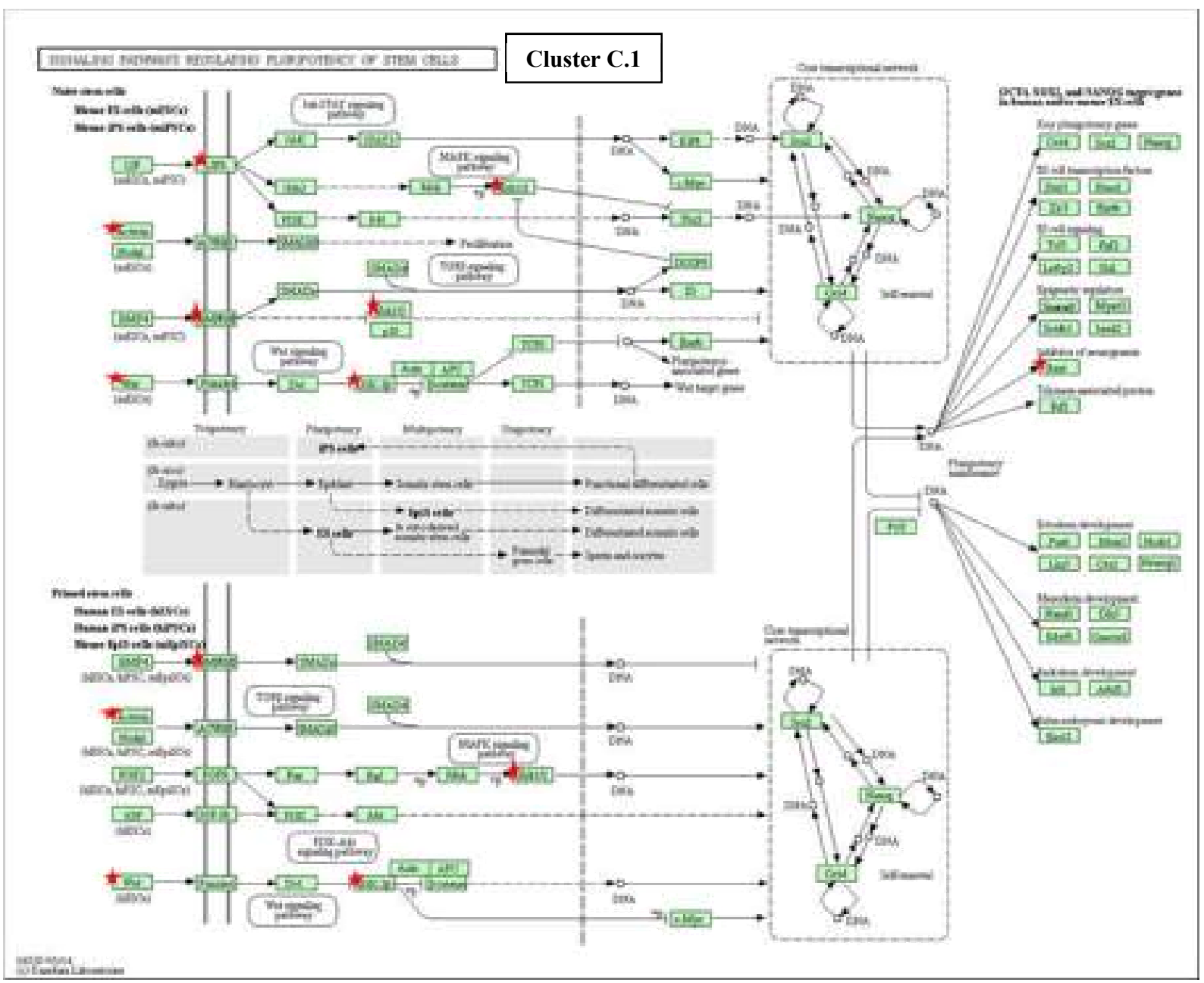

Figura S41. Representação das vias de sinalização regulando a pluripotência em células-tronco a partir da ferramenta DAVID com a análise dos genes alvos compartilhados entre os miRNAs do cluster C.1 (em H1), onde os grupos de genes (associados por suas funções biológicas na via) marcados com as estrelas vermelhas são aqueles em que um ou mais alvos do cluster se encontram. 


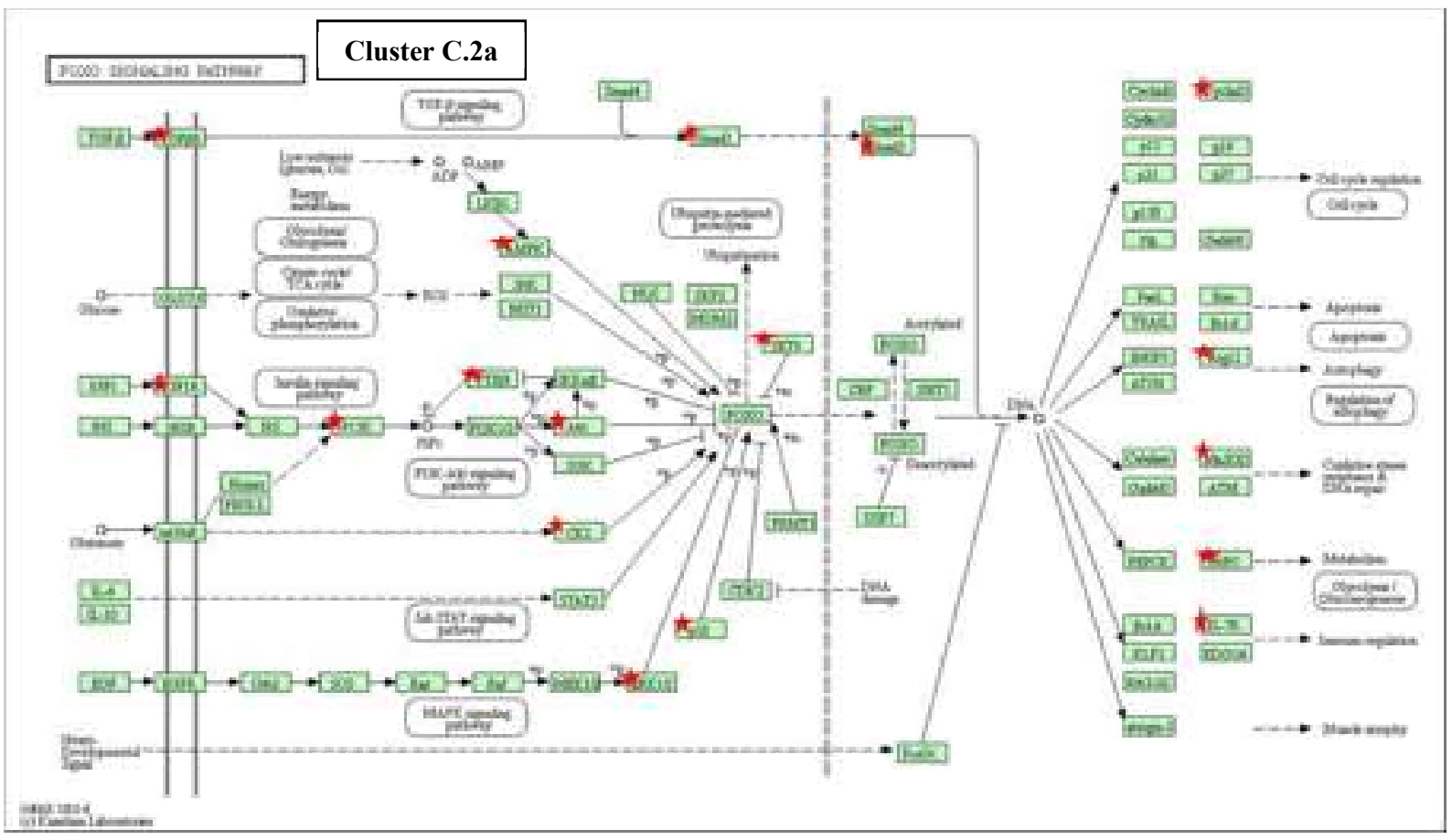

Figura S42. Representação da via de sinalização de FOXO a partir da ferramenta DAVID com a análise dos genes alvos compartilhados entre os miRNAs do cluster C.2a (em H1), onde os grupos de genes (associados por suas funções biológicas na via) marcados com as estrelas vermelhas são aqueles em que um ou mais alvos do cluster se encontram. 


\section{ANEXOS}

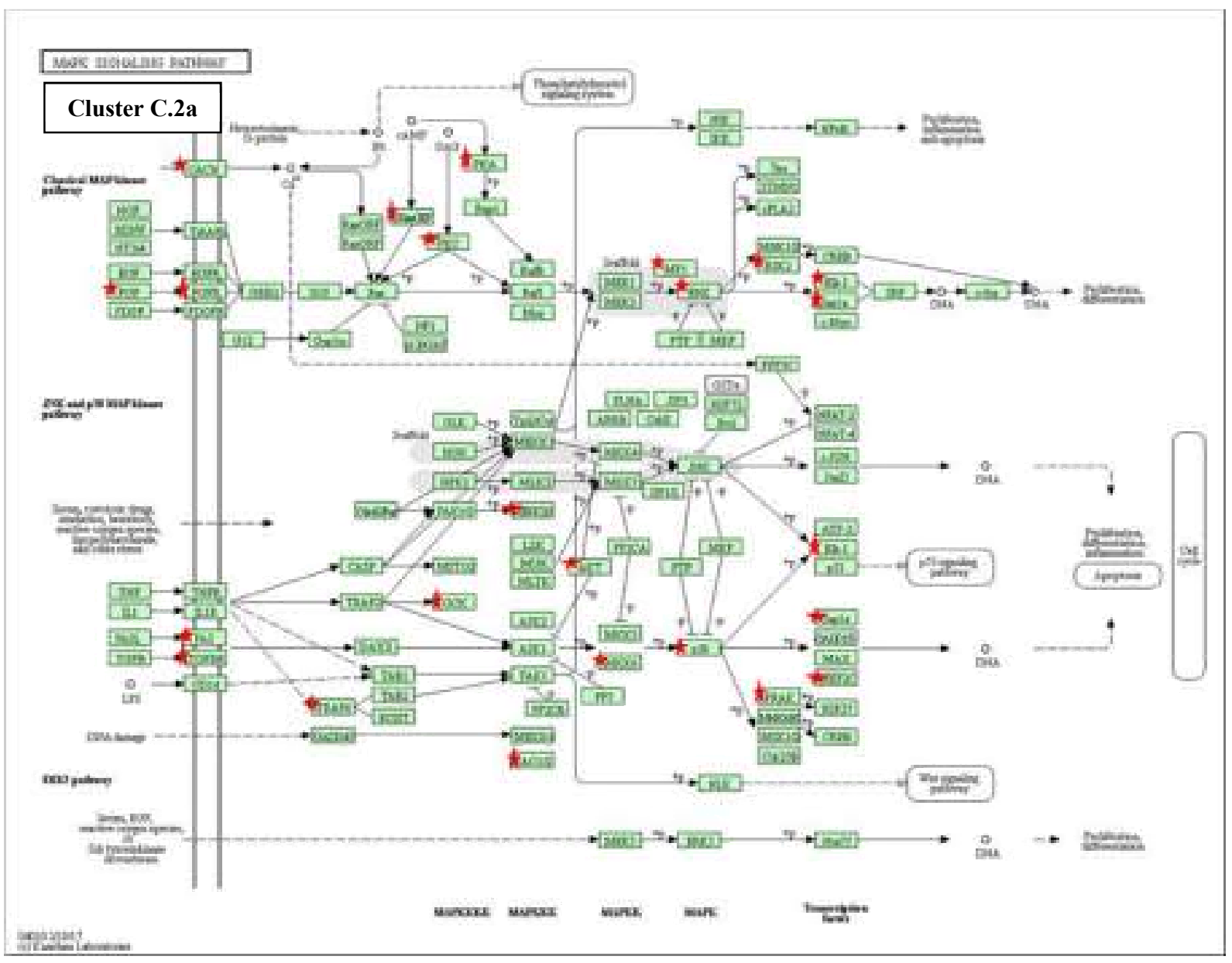

Figura S43. Representação da via de sinalização de MAPK a partir da ferramenta DAVID com a análise dos genes alvos compartilhados entre os miRNAs do cluster C.2a (em H1), onde os grupos de genes (associados por suas funções biológicas na via) marcados com as estrelas vermelhas são aqueles em que um ou mais alvos do cluster se encontram. 


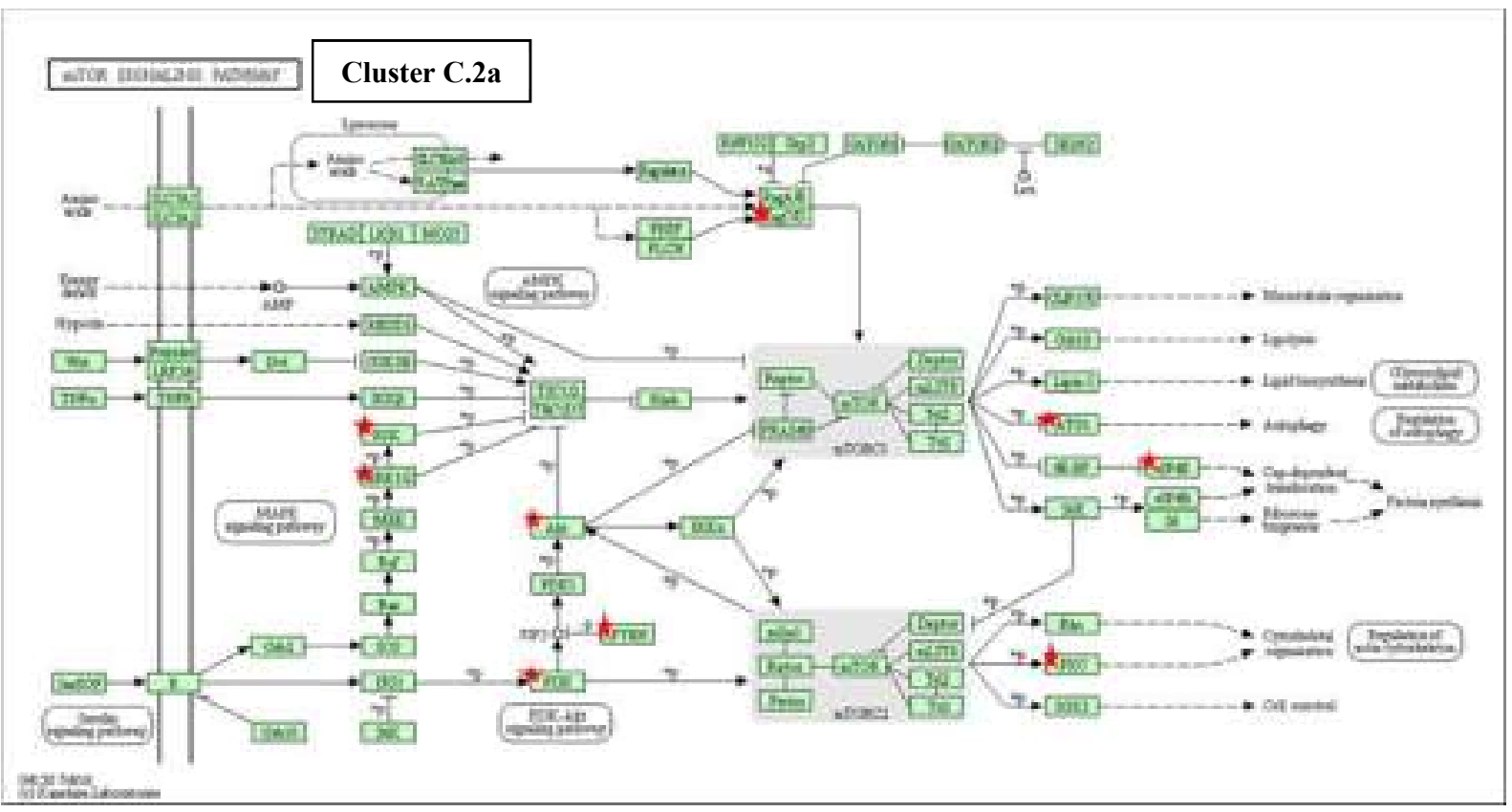

Figura S44. Representação da via de sinalização de mTOR a partir da ferramenta DAVID com a análise dos genes alvos compartilhados entre os miRNAs do cluster C.2a (em H1), onde os grupos de genes (associados por suas funções biológicas na via) marcados com as estrelas vermelhas são aqueles em que um ou mais alvos do cluster se encontram. 


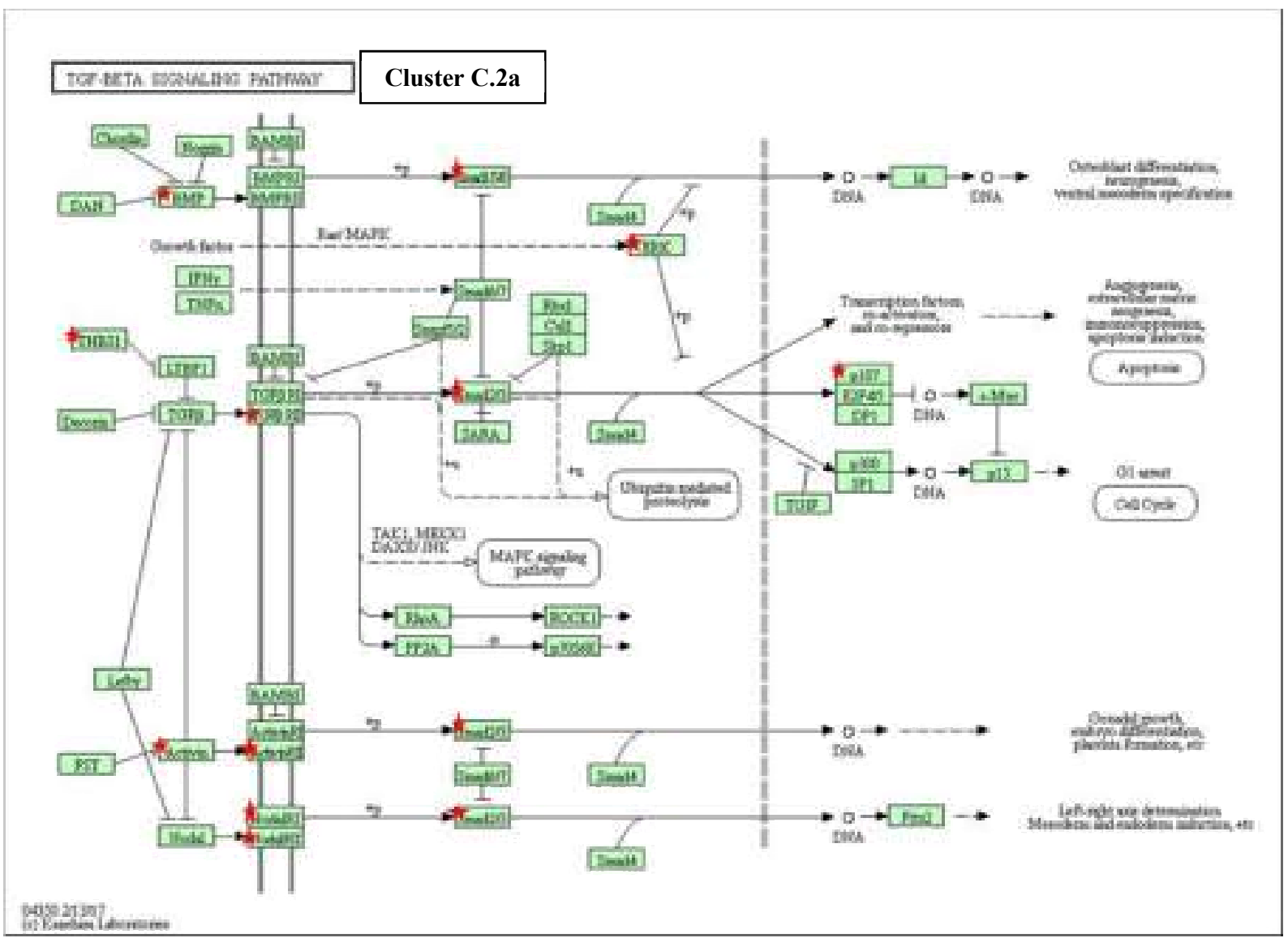

Figura S45. Representação da via de sinalização de TGF $\beta$ a partir da ferramenta DAVID com a análise dos genes alvos compartilhados entre os miRNAs do cluster C.2a (em H1), onde os grupos de genes (associados por suas funções biológicas na via) marcados com as estrelas vermelhas são aqueles em que um ou mais alvos do cluster se encontram. 


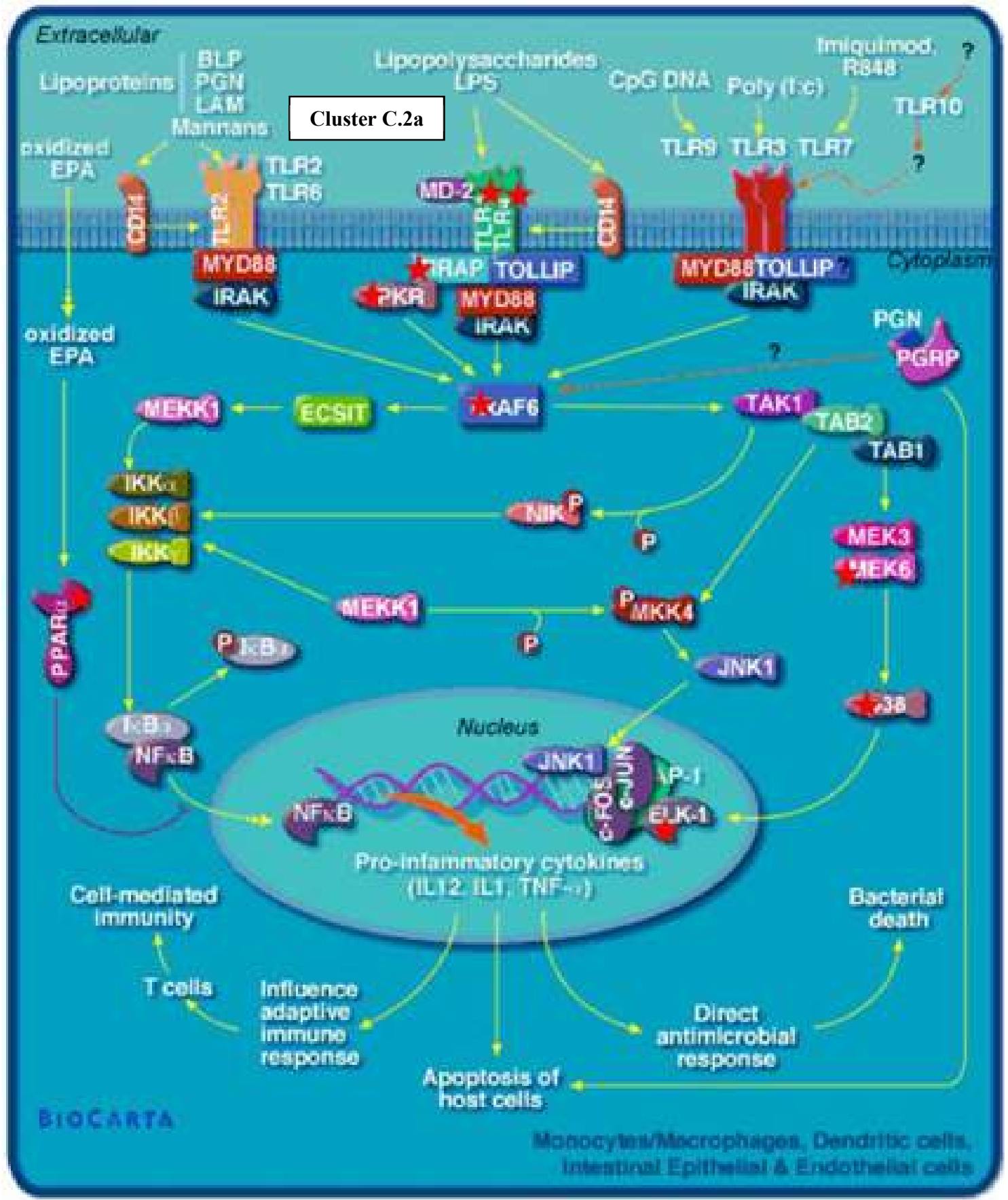

Figura S46. Representação da via de sinalização de Toll-like receptor a partir da ferramenta DAVID com a análise dos genes alvos compartilhados entre os miRNAs do cluster C.2a (em H1), onde os grupos de genes (associados por suas funções biológicas na via) marcados com as estrelas vermelhas são aqueles em que um ou mais alvos do cluster se encontram. 


\section{ANEXOS}

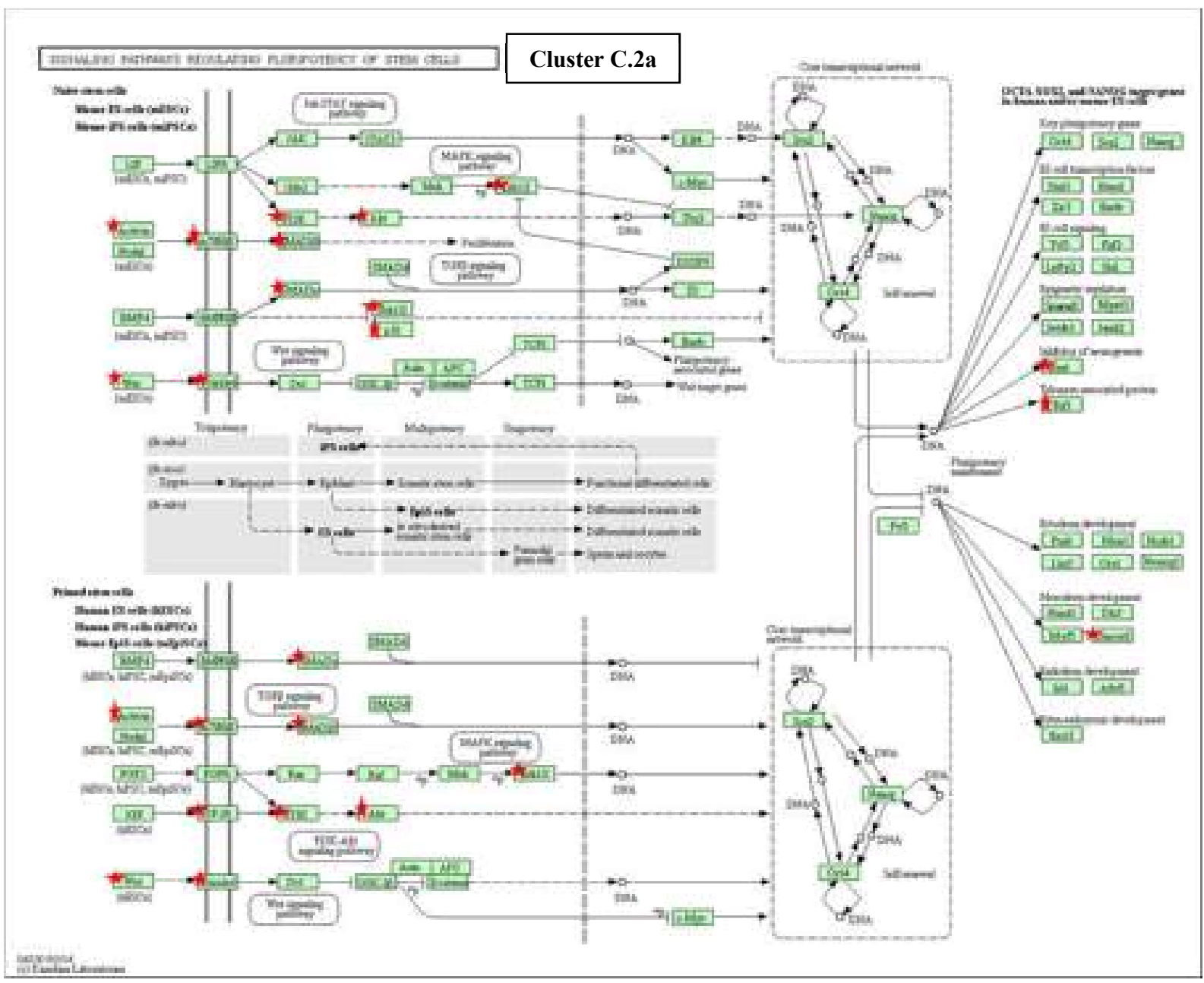

Figura S47. Representação das vias de sinalização regulando a pluripotência em células-tronco a partir da ferramenta DAVID com a análise dos genes alvos compartilhados entre os miRNAs do cluster C.2a (em H1), onde os grupos de genes (associados por suas funções biológicas na via) marcados com as estrelas vermelhas são aqueles em que um ou mais alvos do cluster se encontram. 


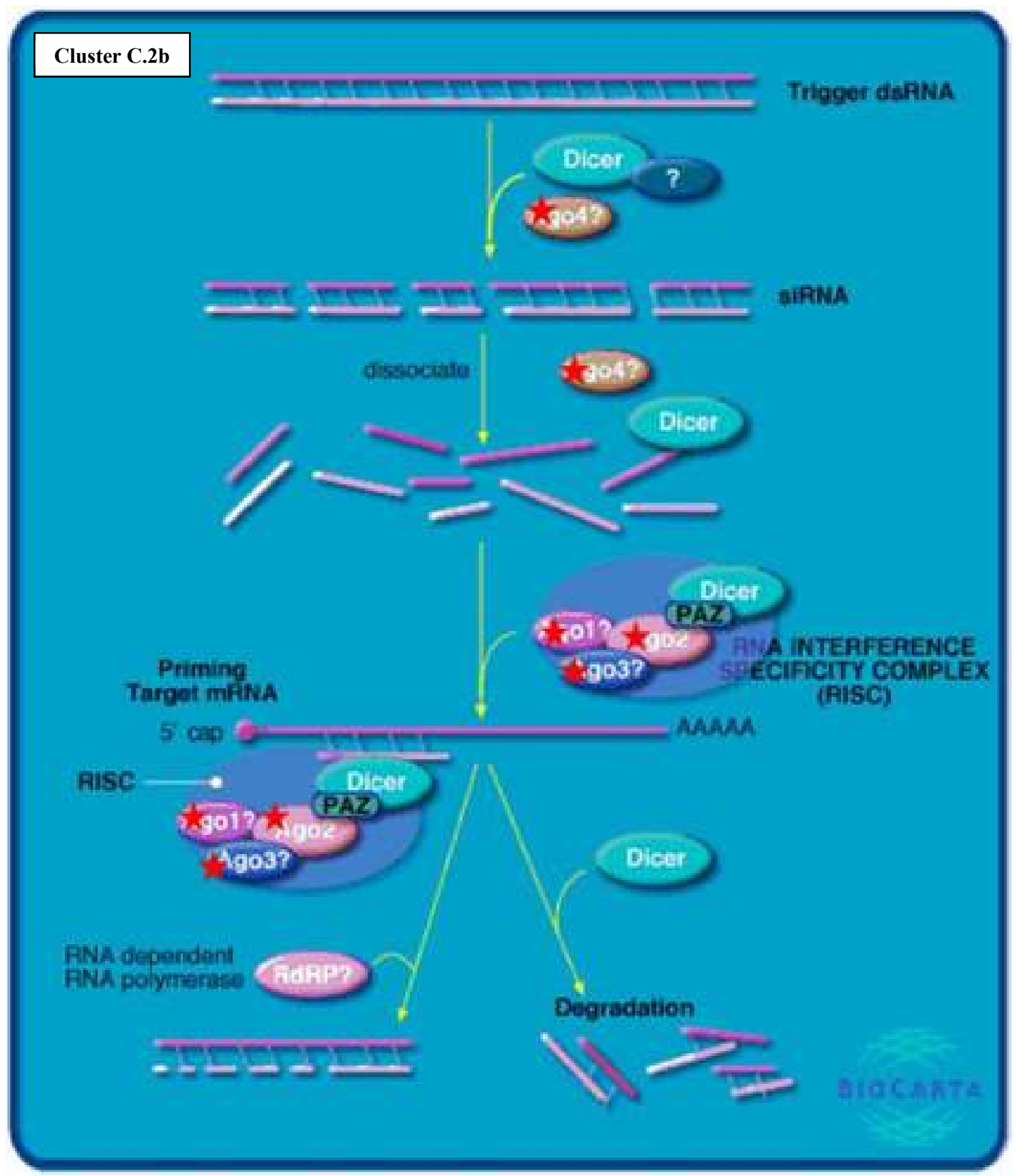

Figura S48. Representação da via de DICER a partir da ferramenta DAVID com a análise dos genes alvos compartilhados entre os miRNAs do cluster C.2b (em H1), onde os grupos de genes (associados por suas funções biológicas na via) marcados com as estrelas vermelhas são aqueles em que um ou mais alvos do cluster se encontram. 


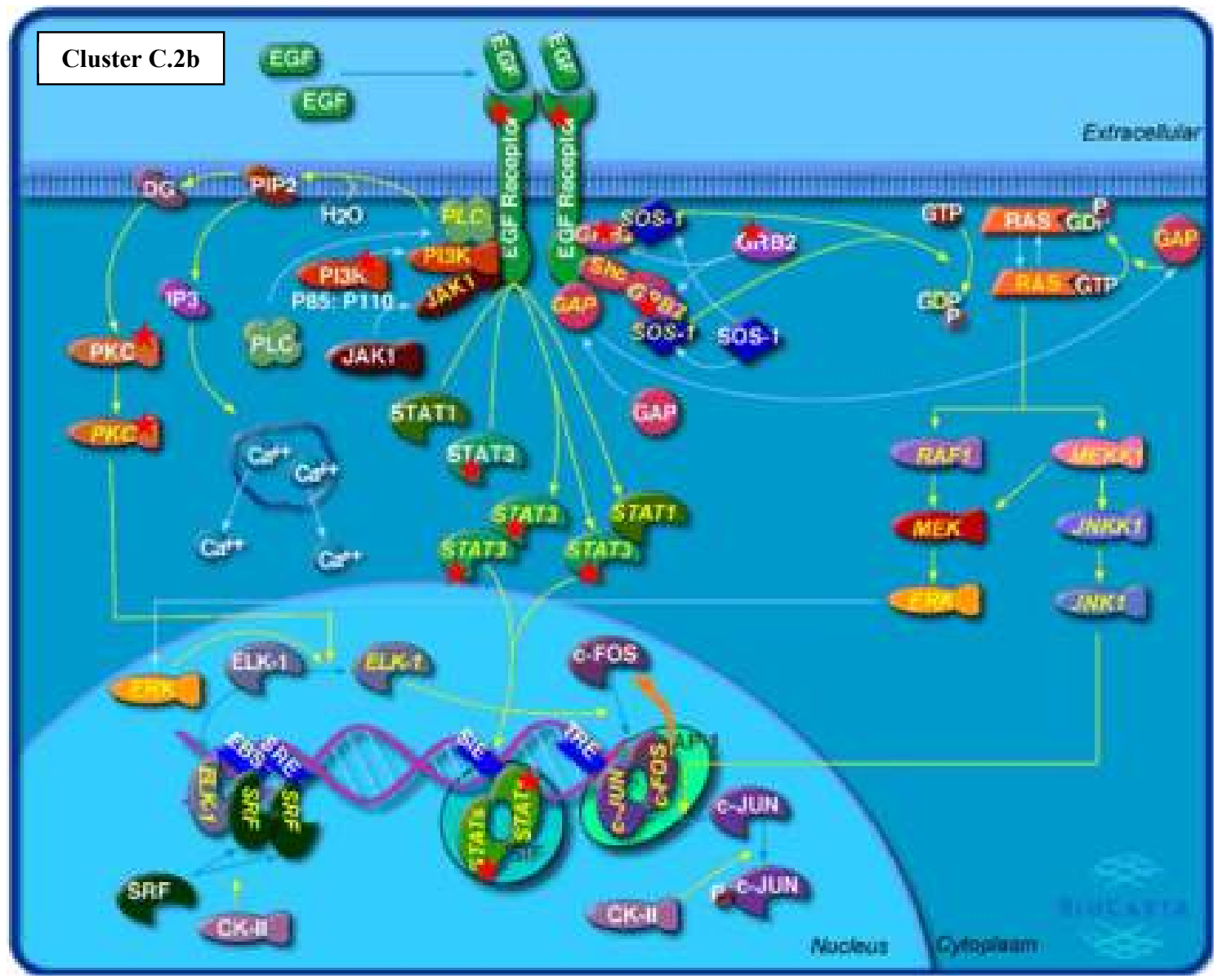

Figura S49. Representação da via de sinalização de EGF a partir da ferramenta DAVID com a análise dos genes alvos compartilhados entre os miRNAs do cluster C.2b (em H1), onde os grupos de genes (associados por suas funções biológicas na via) marcados com as estrelas vermelhas são aqueles em que um ou mais alvos do cluster se encontram. 


\section{ANEXOS}

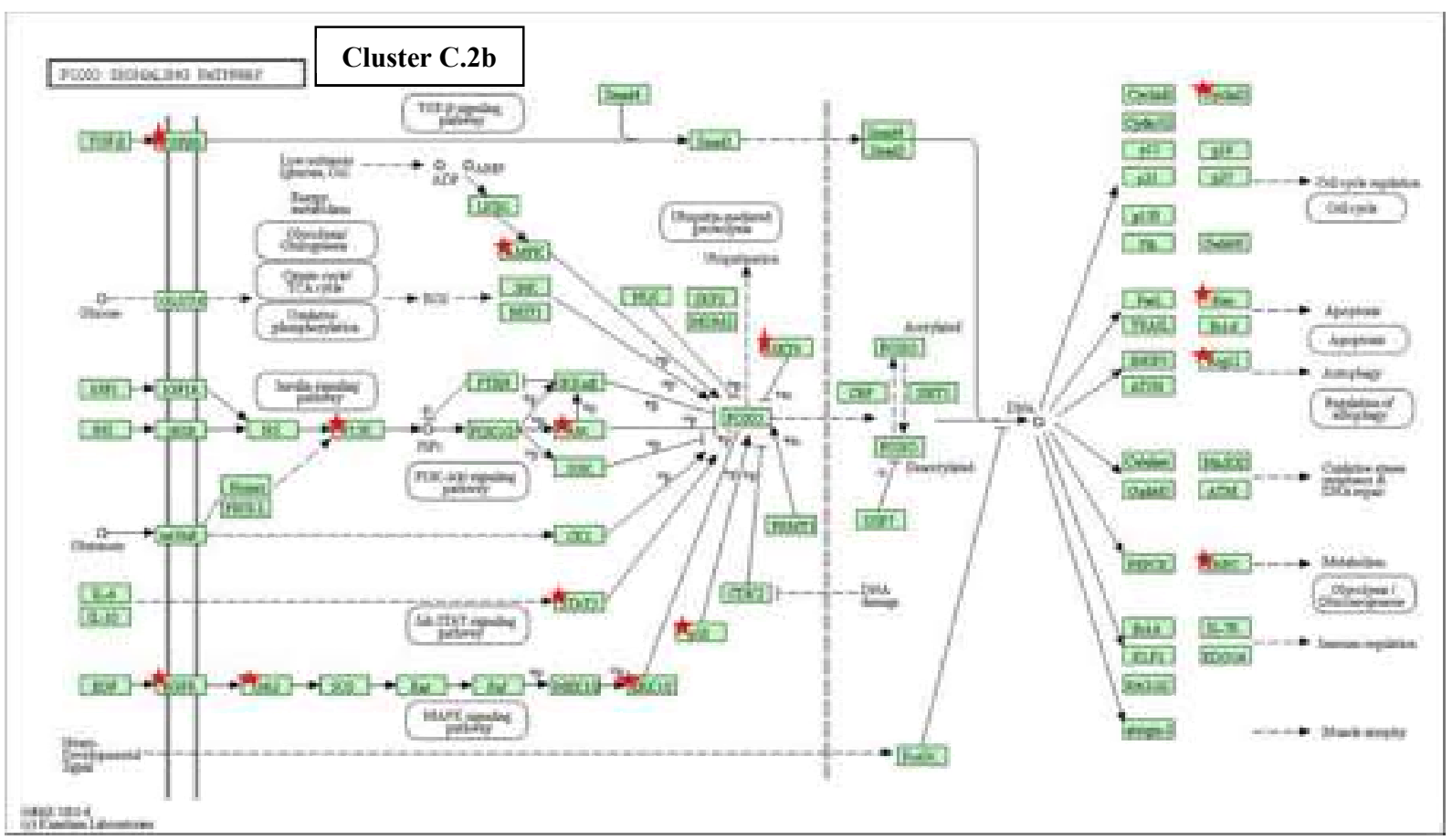

Figura S50. Representação da via de sinalização de FOXO a partir da ferramenta DAVID com a análise dos genes alvos compartilhados entre os miRNAs do cluster C.2b (em H1), onde os grupos de genes (associados por suas funções biológicas na via) marcados com as estrelas vermelhas são aqueles em que um ou mais alvos do cluster se encontram. 


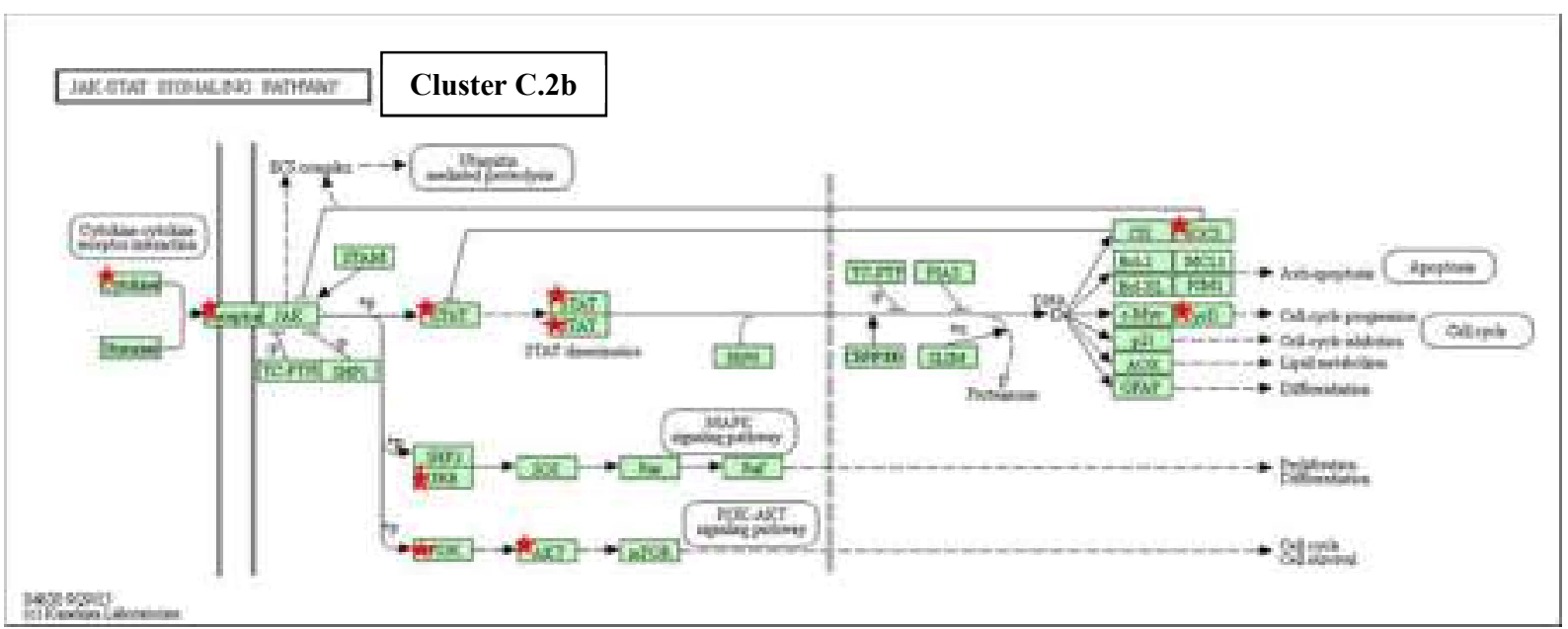

Figura S51. Representação da via de sinalização JAK-STAT a partir da ferramenta DAVID com a análise dos genes alvos compartilhados entre os miRNAs do cluster C. $2 \mathrm{~b}$ (em H1), onde os grupos de genes (associados por suas funções biológicas na via) marcados com as estrelas vermelhas são aqueles em que um ou mais alvos do cluster se encontram. 


\section{ANEXOS}

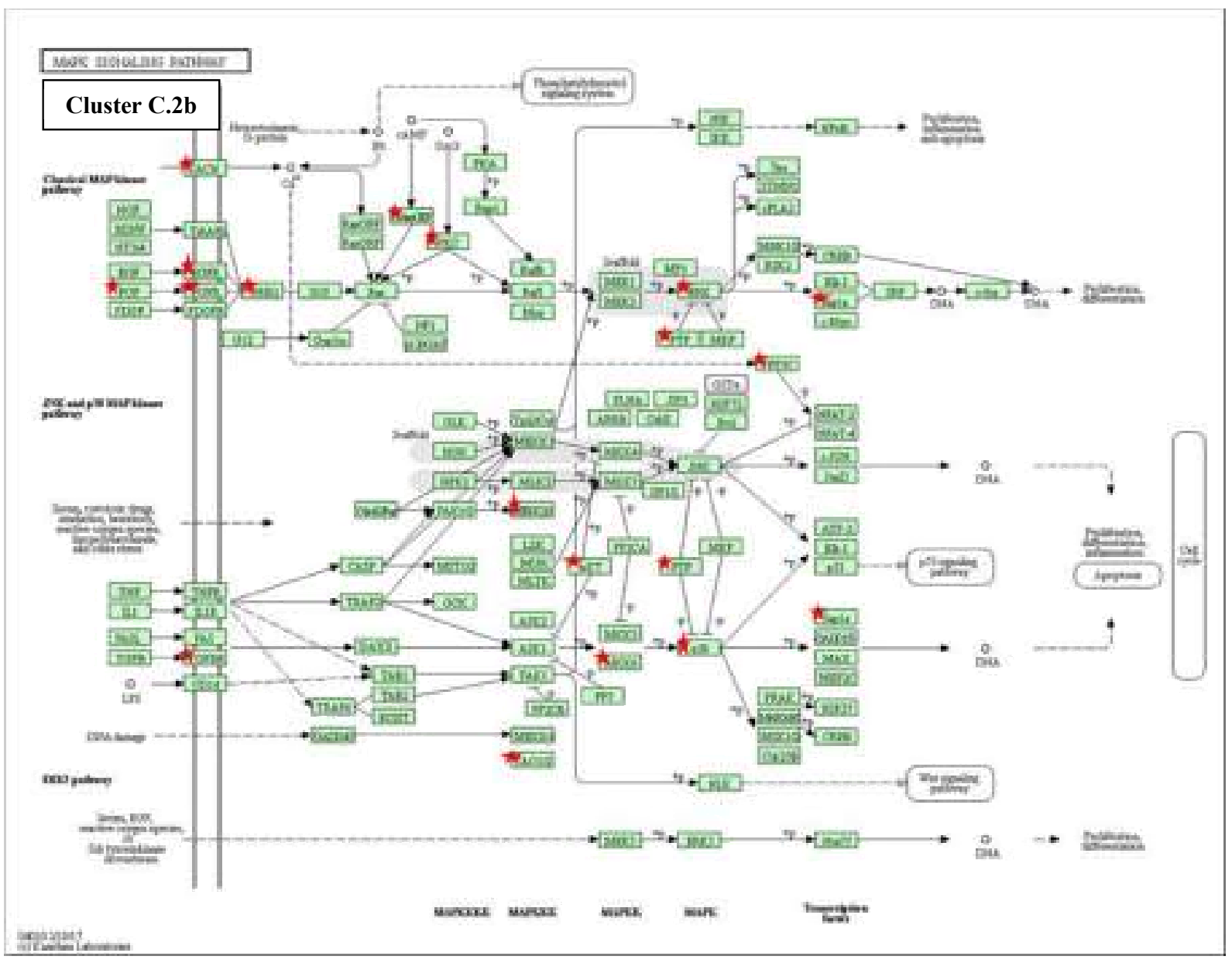

Figura S52. Representação da via de sinalização MAPK a partir da ferramenta DAVID com a análise dos genes alvos compartilhados entre os miRNAs do cluster C.2b (em H1), onde os grupos de genes (associados por suas funções biológicas na via) marcados com as estrelas vermelhas são aqueles em que um ou mais alvos do cluster se encontram. 


\section{ANEXOS}

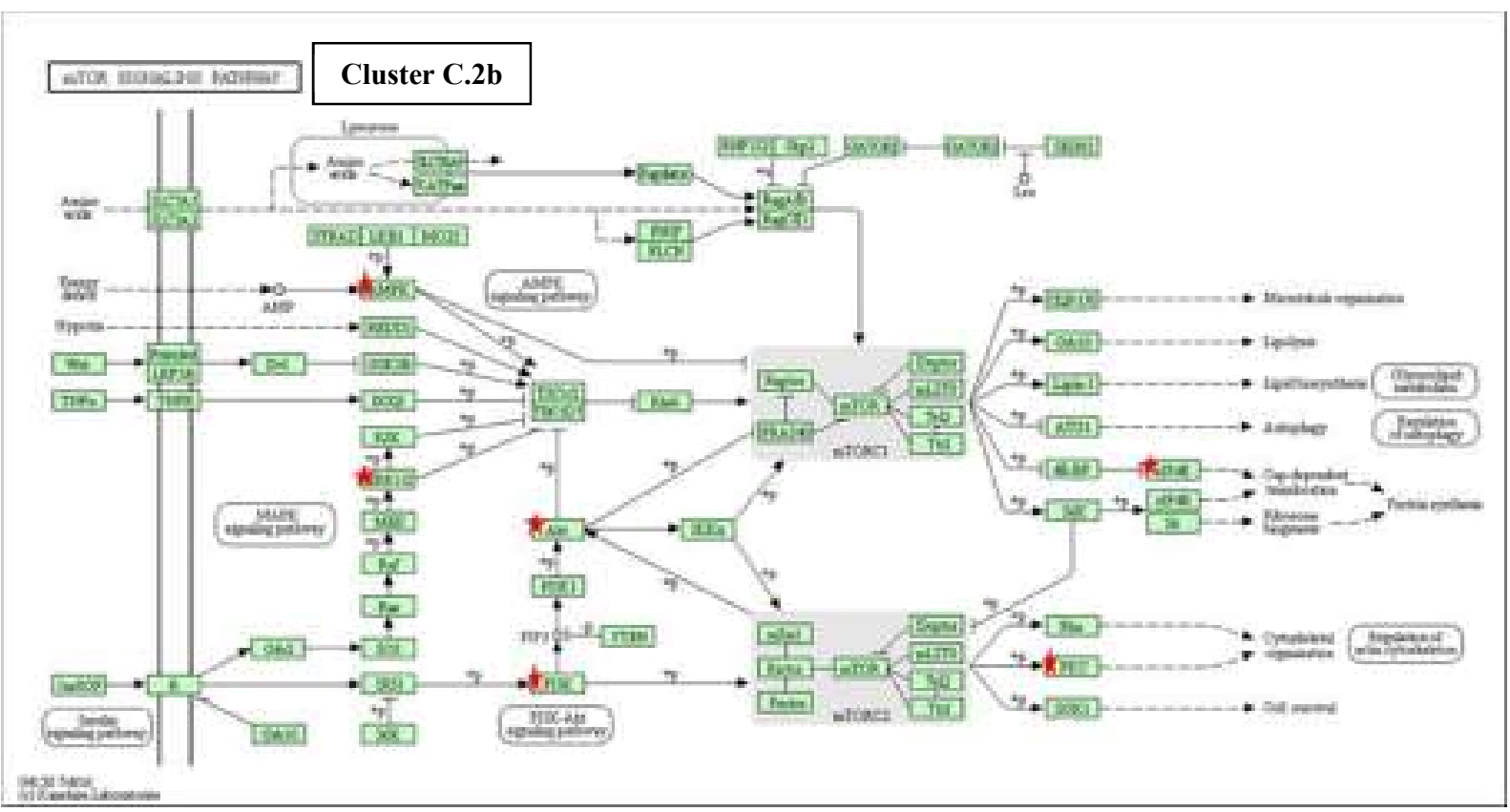

Figura S53. Representação da via de sinalização de mTOR a partir da ferramenta DAVID com a análise dos genes alvos compartilhados entre os miRNAs do cluster C.2b (em H1), onde os grupos de genes (associados por suas funções biológicas na via) marcados com as estrelas vermelhas são aqueles em que um ou mais alvos do cluster se encontram. 


\section{ANEXOS}

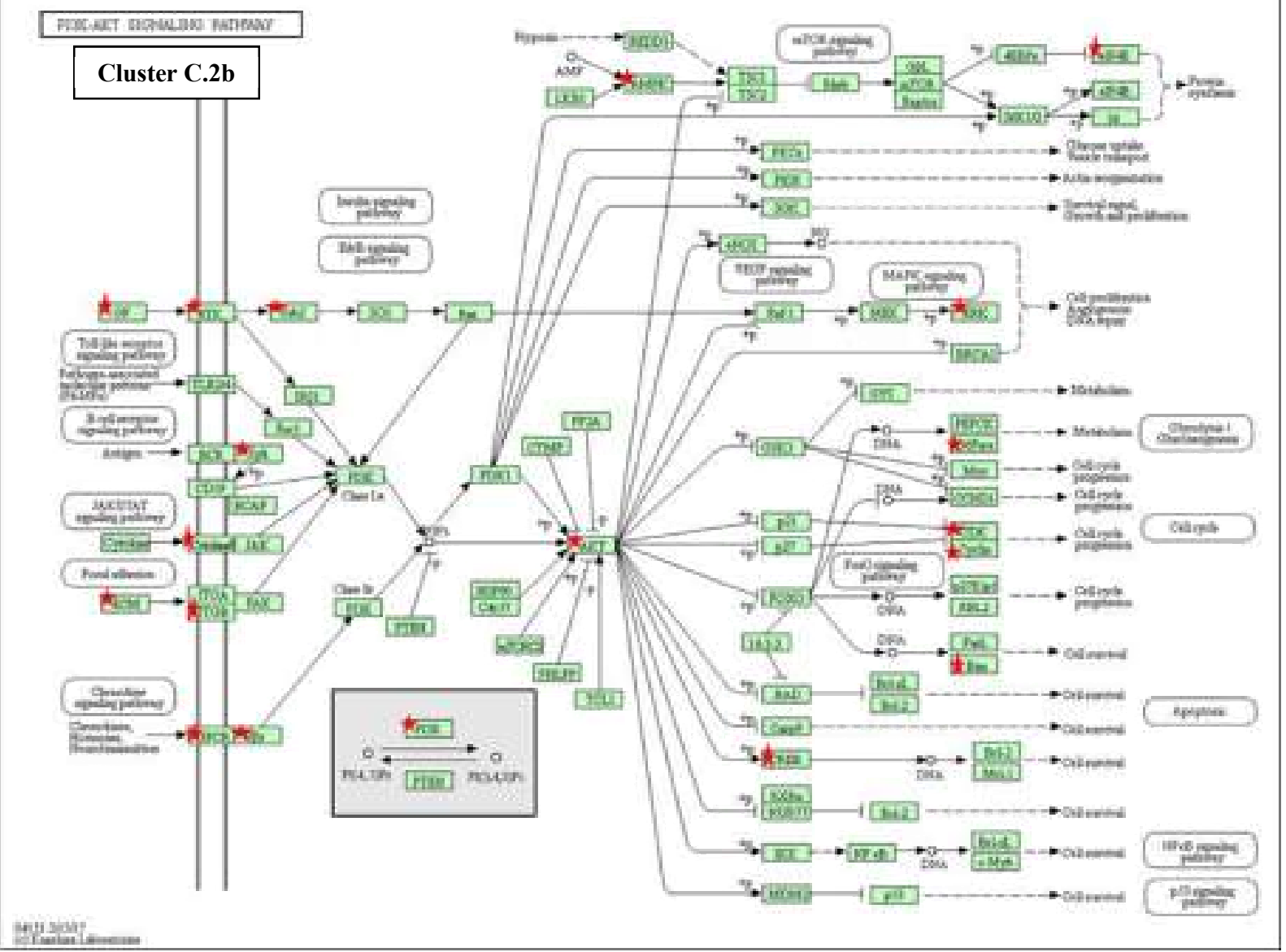

Figura S54. Representação da via de sinalização PI3K-AKT a partir da ferramenta DAVID com a análise dos genes alvos compartilhados entre os miRNAs do cluster C.2b (em H1), onde os grupos de genes (associados por suas funções biológicas na via) marcados com as estrelas vermelhas são aqueles em que um ou mais alvos do cluster se encontram. 


\section{ANEXOS}

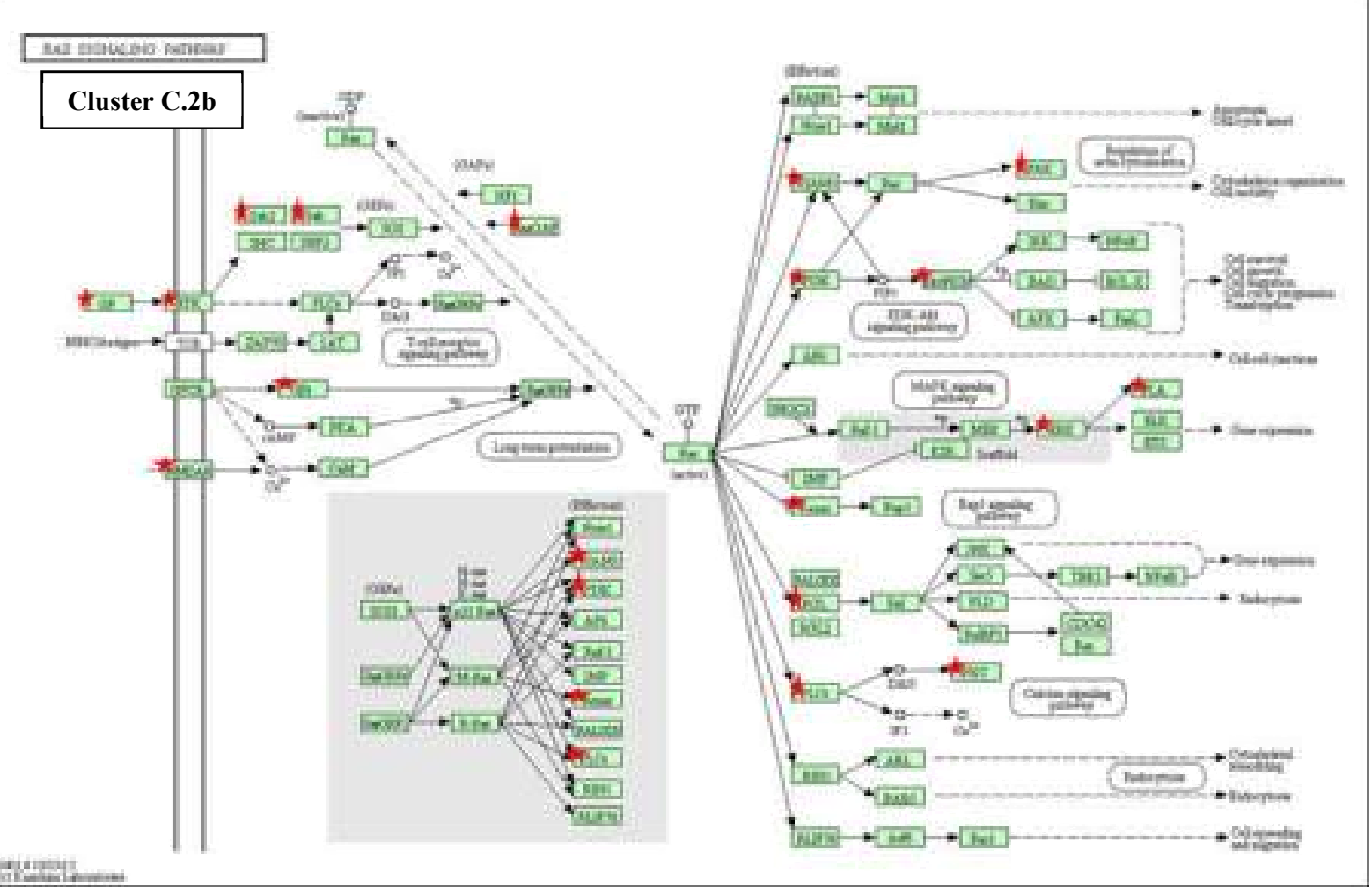

Figura S55. Representação da via de sinalização de RAS a partir da ferramenta DAVID com a análise dos genes alvos compartilhados entre os miRNAs do cluster C.2b (em H1), onde os grupos de genes (associados por suas funções biológicas na via) marcados com as estrelas vermelhas são aqueles em que um ou mais alvos do cluster se encontram. 


\section{ANEXOS}

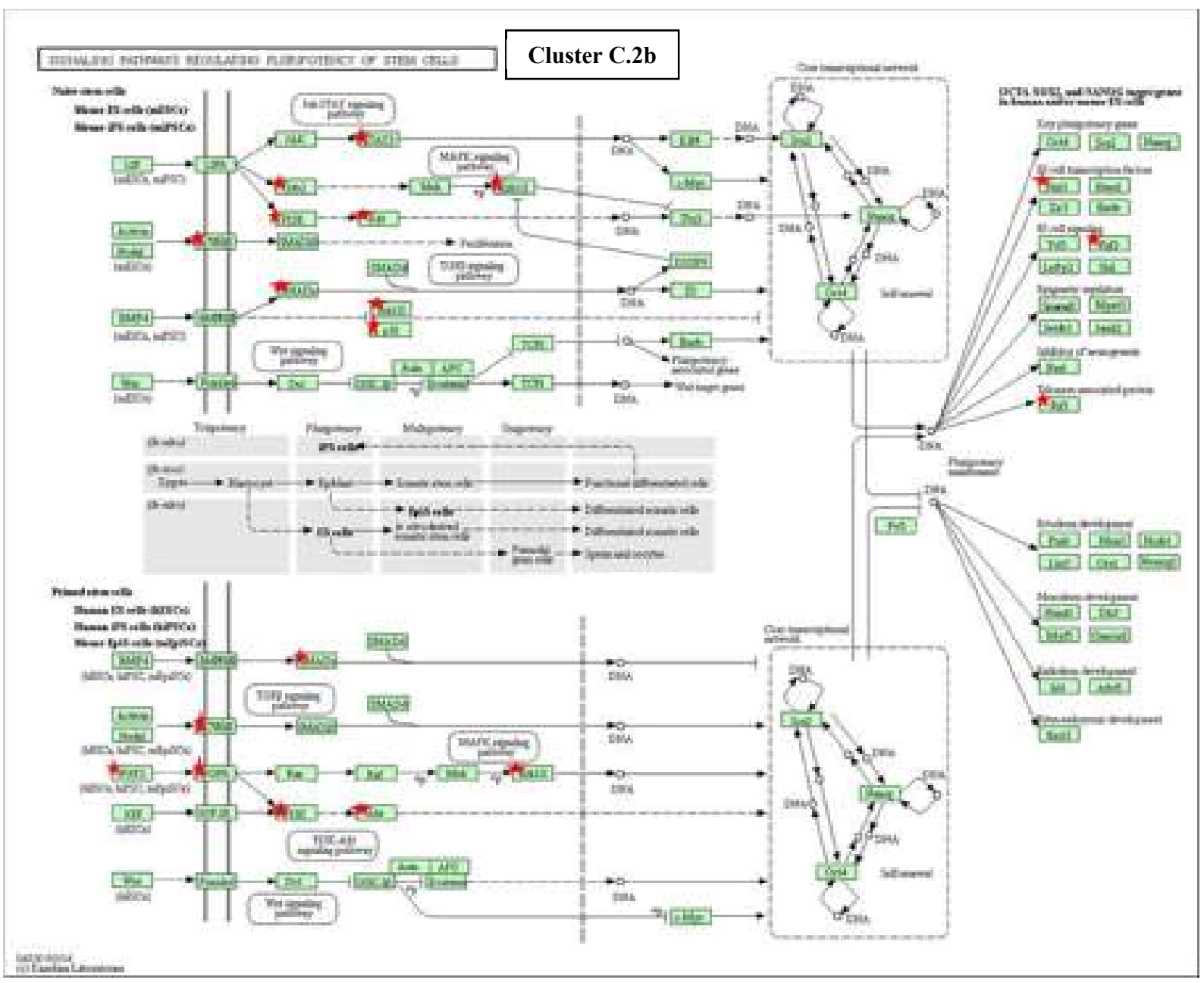

Figura S56. Representação das vias de sinalização regulando a pluripotência de células-tronco a partir da ferramenta DAVID com a análise dos genes alvos compartilhados entre os miRNAs do cluster C.2b (em H1), onde os grupos de genes (associados por suas funções biológicas na via) marcados com as estrelas vermelhas são aqueles em que um ou mais alvos do cluster se encontram. 
Cluster C.2c

-
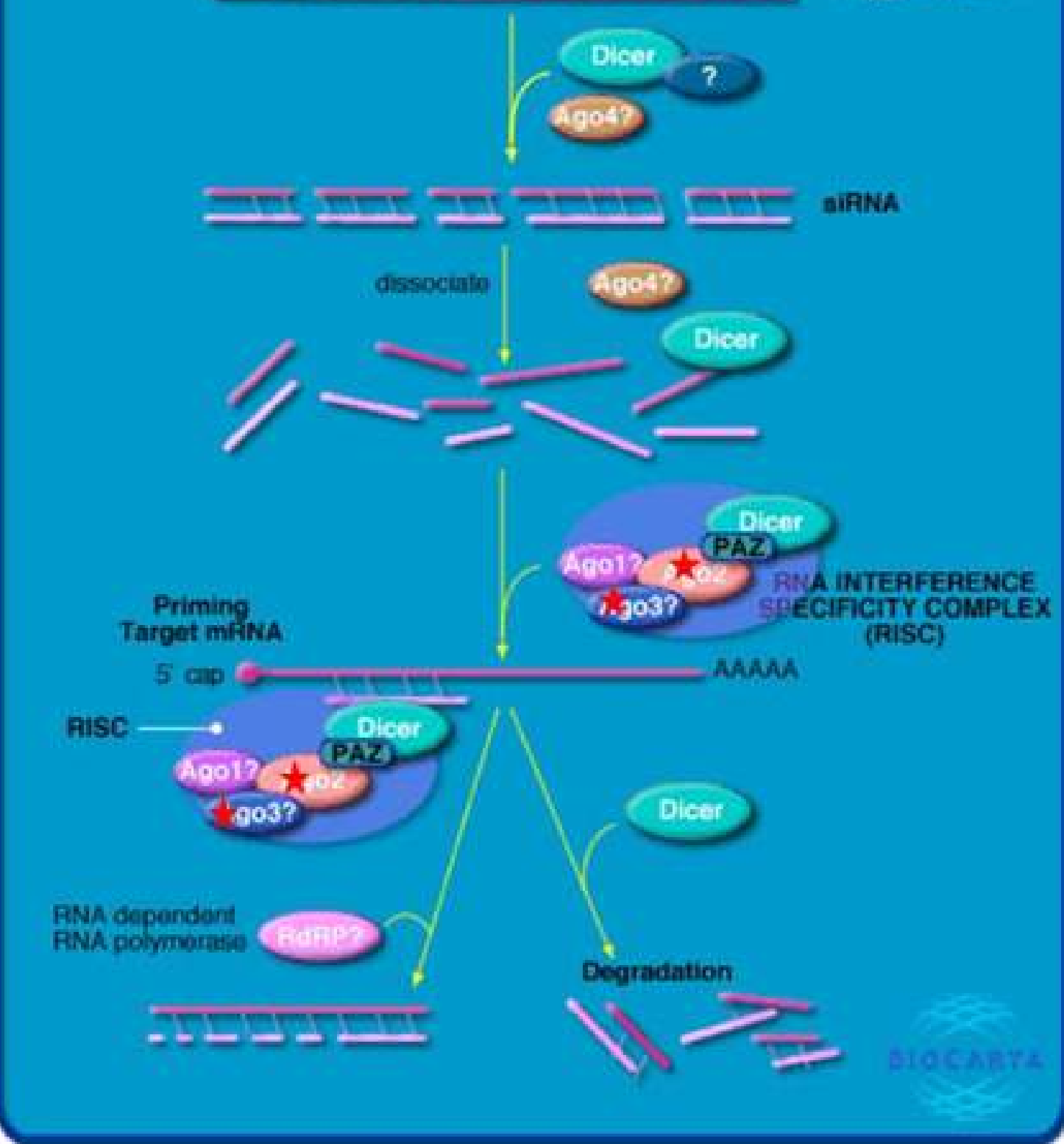

Figura S57. Representação da via de DICER a partir da ferramenta DAVID com a análise dos genes alvos compartilhados entre os miRNAs do cluster C.2c (em H1), onde os grupos de genes (associados por suas funções biológicas na via) marcados com as estrelas vermelhas são aqueles em que um ou mais alvos do cluster se encontram. 


\section{ANEXOS}

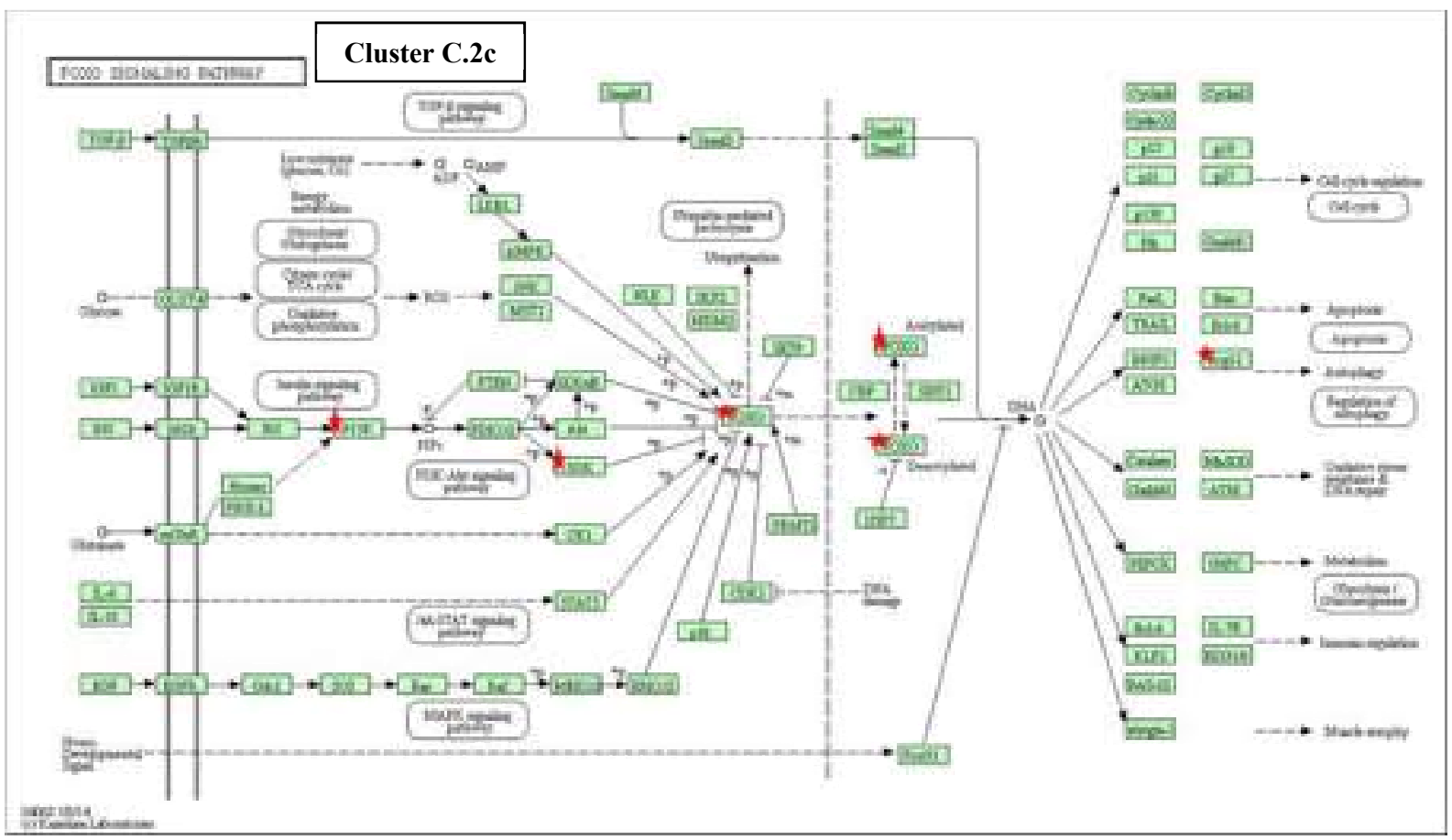

Figura S58. Representação da via de sinalização de FOXO a partir da ferramenta DAVID com a análise dos genes alvos compartilhados entre os miRNAs do cluster C.2c (em H1), onde os grupos de genes (associados por suas funções biológicas na via) marcados com as estrelas vermelhas são aqueles em que um ou mais alvos do cluster se encontram. 
Anexo V - Manuscrito do presente estudo EM PREPARAÇÃo

Identification of miRNA-regulated pathways in cell differentiation and pluripotency maintaining using High Content Analysis.

Ildercílio Mota de Souza Lima ${ }^{1}$, Sarah Blima Paulino Leite ${ }^{1}$, Hudson Lenormando de Oliveira Bezerra $^{1}$, Josiane Lilian dos Santos Schiavinato ${ }^{1}$, Bruno Graga Sangiorgi ${ }^{1}$, Amélia Goes Araújo $^{1}$, Dimas Tadeu Covas ${ }^{2}$, Rodrigo Alexandre Panepucci ${ }^{1,2}$.

${ }^{1}$ Department of Genetics, Faculty of Medicine, University of São Paulo, RibeirãoPreto, SP, Brazil. ${ }^{2}$ National Institute of Science and Technology in Stem Cell and for Cell Therapy (INCTC) Center for Cell Therapy (CTC) and Regional Blood Center. RibeirãoPreto, SP, Brazil.

\section{Correspondence:}

Rodrigo Alexandre Panepucci, PhD.

Fundação Hemocentro de Ribeirão Preto

R. Tenente Catão Roxo, 2501

14051-140 Ribeirão Preto, Brazil

Telephone +55.16 .3602 .2223$

$\mathrm{Fax}+55.16 .2101 .9309$

e-mail: rapane@gmail.com 


\begin{abstract}
microRNAs (miRs) play an important role in stem cell's biology by binding to target mRNAs transcripts, inducing translation blockage and/or transcripts degradation. Upon differentiation of pluripotent cells, miRNAs can be induced or repressed, however, their specific roles are largely unexplored. We investigated the functional roles of a selected set of miRs in pluripotency and differentiation, using quantitative automated fluorescence microscopy (High Content Analysis). For this, we used NTera-2 (human embryonal carcinoma cells, ECC) and H1 (embryonic stem cells; ESC) as models. These cells were reverse-transfected with thirty distinct miRs mimics (individually) or control molecules. Following 3-4 days of culture, cells were fixed, permeabilized and stained with Hoechst/CellMask Blue (nucleus/cytoplasm), anti-OCT4, anti-Cyclin B1 and imaged using an ImageXpress Micro HCA System. CellProfiler was used to quantify several morphometric parameters and intensity measurements of OCT4 and CYCB1 in nuclear and cytoplasmic compartments. Quantified parameters were used to generate miR-specific multiparametric phenotypic profiles (using KNIME) and clustering these data led to identification of pathways and processes involved in the induction of pluripotency or cell diferention features caused by miRs with similar phenotypic effects. in the control of pluripotency. As an example, PI3KAKT, WNT, TGF $\beta$ and DICER pathways were found regulated by some phenotypic clusters and transcripts level of some of miR targets were evaluated by qPCR to validate de findings. Part of the work was focused in the regulation of Notch pathway by miRNAs in pluripotent cells, which led the observation that miR-363-3p inhibits Notch signaling and promotes pluripotency feature, as the transfection with miR-363-3p mimic not only enhanced pluripotent phenotype in NTera-2 and H1, but also protected de ECCs from differentiation induced by coculture with OP9 expressing DLL1 and decreased PSEN1 transcripts level.
\end{abstract}

Keywords: High Content Analysis, microRNAs, Pluripotency, Embryonic Stem Cells, Embryonal Carcinoma Cells. 


\section{Introduction}

In addition to the ample transcriptional control mediated by TFs, microRNAs (miRNAs) have been recognized as major post-transcriptional regulators of gene expression. These are small $(\sim 22 \mathrm{nt})$ RNA molecules that bind to partially complementary target mRNAs, blocking their translation and/or leading to their degradation . Despite their relatively low number - 2,588 mature miRNAs are currently annotated in the human genome, according to the latest release of miRBase (release 21, June 2014) - miRNAs have been shown to directly regulate a large fraction of the transcriptome. The participation of miRNAs in the most diverse biological processes for the maintenance of life has been widely studied. It is known that miRNAs act in the regulation of cycle, death and cell differentiation, as well as the development of the most different organisms (BUENO; MALUMBRES, 2011; CARLETON; CLEARY; LINSLEY, 2007; HOUBAVIY; MURRAY; SHARP, 2003; IVEY; SRIVASTAVA, 2010; LÜNINGSCHRÖR et al., 2013; SAYED; ABDELLATIF, 2011; SU et al., 2015; WIENHOLDS; PLASTERK, 2005), which are straighly related to a group of cells known as stem cells (SC), as the embryonic stem cells (ESCs).

Self-renew and pluripotency are the key features of embryonic stem cells (ESCs). Over the last years, a great effort has been devoted to the study of these basic properties, given the enormous potential for the application of ESCs in regenerative medicine. The understanding of some of the regulatory networks acting on ESCs, led to the identification of a core set of transcription factors (TFs) able to regulate the transcription of a large number of additional factors involved in the control of pluripotency and differentiation. This knowledge ultimately led to the discovery that somatic cells can be reprogramed into induced pluripotent stem cells (iPSCs), by introducing different combinations of pluripotency-related transcription factors, such as OCT4, SOX2, KLF4, and c-MYC The interest in miRNAs in the context of pluripotency led to the identification of miRNAs specifically expressed in pluripotent cells (e.g. miR-17 and miR-302 miRNA families), that are implicated in the maintenance of their characteristics. Many studies have shown that the ectopic expression of miRNAs preferentially expressed in pluripotent SCs, can improve the reprograming induced by the classical TFs, or even completely substitute them

Despite the developments in functional genomics, with genome-wide methods capable of profiling pluripotent stem cells in terms of the transcriptome, proteome and miRNome, a true understanding of how these cells behave, depends on assays and instruments, capable to identify and quantify molecular and most importantly phenotypic events at the single-cell level. In this context, the field collectively called as high-content analysis (HCA), has recently emerged as a powerful tool in the study of stem cells .

In this sense, the present study aimed to evaluate a set of miRNAs differentialy expressed in pluripotente cells and cells under differentiation and use the HCA approuch to generate multiparametric profile of the changes caused by the miRNA, following the identification of miRNAs causing similar phenotypic effects and the target mRNA-transcripts and biological pathways shared by them. 


\section{Material and Methods}

\section{Cell Culture}

For the development of the present work, two pluripotent cell lines were used, the human embryonic carcinoma cells NTera-2 cl.D1 and the human embryonic cells H1. The NTera-2 lineage was obtained from the Cell Bank of Rio de Janeiro (BCRJ) and cultured in DMEM (Dulbecco's Modified Eagle's Medium high glucose, Gibco, \# 12800-017), supplemented with 10\% fetal bovine serum (SFB, GE Life Sciences, \# SH30071.03), in culture flasks of 25,75 or $175 \mathrm{~cm}^{2}$. The H1 strain was supplied by the Cell Therapy Laboratory. For the present study, these cells were cultured in a feeder-free culture (MEFs) using the GelTrex matrix (Gibco, \# A1413302) and the mTeSR TM culture medium 1 (STEMCELL Technologies, \# 5850) in 6-well plates. In addition, a monolayer growth adaptation was previously performed, since embryonic stem cell cultures are generally performed in colonies and, thus, quantitative analysis of the images could be impaired. To inhibit spontaneous differentiation by being found in single cells, as a result of the enzymatic peal, a Rock inhibitor (Hydrochloride Y-27632, Abcam, \# ab120129) at the concentration of $10 \mu \mathrm{M}$ was used. Cells were stored in liquid nitrogen in freezing solution, composed of mTeSR тм 1, Rock inhibitor $(10 \mu \mathrm{M})$ and 10\% DMSO. Both cell lines were maintained in a humidified incubator, with controlled air humidity $(85 \%)$, temperature $\left(37^{\circ} \mathrm{C}\right)$ and $\mathrm{CO} 2$ concentration $(5 \%)$. These lines showed negative results in the test for mycoplasma contamination (MycoAlertTM Mycoplasma Detection Kit, Lonza, \# LT07), and were investigated by immunofluorescence microscopy for the expression of known pluripotency markers: OCT4 (anti-OCT4, Santa Cruz Biotechnology (Anti-SOX-2, Santa Cruz Biotechnolody, \# sc-365823), TRA-1-81 (anti-TRA-1-81, Santa Cruz Biotechnology, \# sc-21706)

\section{miR mimic transfection}

Lipofectamine $2000(0,05 \mu \mathrm{L} / 100 \mu \mathrm{L})$ and DharmaFECT-4 $(0,1 \mu \mathrm{L} / 100 \mu \mathrm{L})$ were used to transfect $50 \mathrm{nM}$ of synthetic-miR mimics Pre-miR TM miRNA Precursors (Thermo Fisher Scientific), as the negative and positive controls in NTera-2 cl. D1 and H1 cells respectively, according to the manufacturer's instructions. NTera-2 cells were cultured for 4 days and H1 for 3 days before the fixation to be evaluated by immunofluorescence. For qPCR analysis, NTera-2 cells were transfected and the total RNA was obtained 2 days after transfection.

\section{Immunofluorescence and High Content Analysis}

For the HCA assay, cells were transfected with $31 \mathrm{miR}$ mimic molecules (individualy) known as differentialy expressed in undifferentiated pluripotent cells and their counterpart under differentiation (MARSON et al., 2008a; STADLER et al., 2010). After transfection and incubation, cell were washed with PBS and fixed using a $2 \%$ solution of formaldehyde in ice-cold methanol, followed by quenching step with glycine and blocking with $1 \%$ of FBS in PBS. To evaluate the effect of miRNAs on pluripotency, two primary antibodies were used: one for OCT4 (mouse anti-OCT4 mouse IgG, Santa Cruz Biotechnology, \# sc-5279), essential transcription factor for maintenance of pluripotency; and one for Cyclin B1 (anti-Cyclin B1 rabbit IgG, Santa Cruz Biotechnology, \# sc-595), a protein that accumulates in the cytoplasm between S and G2 phases and travels to the cell nucleus during $\mathrm{M}$ phase. Were incubated overnight with the solution containing both primary antibodies $(50 \mu \mathrm{L} /$ well), then washed three times with PBS, then incubated with a solution (50 $\mu \mathrm{L} /$ well) containing the secondary antibodies (goat IgG conjugated to DyLight488 anti- Mouse IgG, dilution: 1: 300, Thermo Scientific, Goat IgG 
conjugated to rabbit anti-IgG DyLight594, dilution: 1: 300, Thermo Scientific, \# 35561), nuclear marker (Hoechst 33342) and The cell marker (CellMask®Blue) for 45 minutes at room temperature. Finally, the wells were washed three times with PBS and maintained with $100 \mu \mathrm{L}$ of PBS for imaging. Photomicrographs were performed using the inverted fluorescence microscope of the HCS ImageXpress XLS system, using the 10X objective DAPI (Hoechst 33342 / CellMask ${ }^{\circledR B l u e), ~ F I T C ~(D y L i g h t 488) ~ a n d ~ T e x a s ~ R e d ~(D y L i g h t 594) ~}$ fluorescence detection cubes Nine images per well were obtained for each of the fluorescence cubes, totaling 27 images per well, 1620 images per plate, 3240 images or $28.9 \mathrm{~GB}$ of data per experiment with each cell line. The images were analyzed by CellProfiler software.

Phenotypic clusterization and pathway analysis

The multiparametric data generated by CellProfiler analysis was exported and, using KNIME, filtered to obtaining the phenotypic profile of each miRNA treatment. These data were clusterized using Cluster 3.0 software and the mRNA-targets of each miRNA in each cluster were compared to find out the shared ones. The result of this analysis was used with DAVID to the idendification of the modulated biological pathways.

\section{RNA isolation and $q R T-P C R$}

Total RNA from all samples was prepared using TRIzol LS, as described by the manufacturer and quantified on a Nanodrop 1000 Spectrophotometer. For reverse transcription of mRNA, we used 1 ug of total RNA with the High Capacity cDNA Reverse Transcription Kit. qPCR was performed using either TaqMan Universal PCR Master Mix or Power SYBR Green PCR Master Mix (all from Thermo Fisher Scientific). Gene expression data was normalized to GAPDH expression, and miR data was normalized to RNU24 and RNU48. Used TaqMan probes and SYBR Green PCR primers are listed in Supplemental Table 1 and 2 respectively.

\section{Regulation of Notch pathway by miRNAs in pluripotent stem cells}

To identify if some miRNA that promoted pluripotency features were modulating Notch signaling pathway, the list of the pathway components and tested miRNAs were crossed, resulting in the identification of 3 miRNAs with a high number of targets in Notch, which were miR-302c-3p, miR-363-3p and miR-92a-3p. NTera-2 cells were transfected in 96-well plates with their miR-mimics and also some other controls: pre-miR negative control, and miR-222-3p and miR-371-3p that presented a very low number of targets into Notch pathway. These cells were incubated for 3 days. Following that, they were co-cultured for 24h with OP9-DL1 cells, to face Notch induction by DLL1. NTera-2 cells transfected with pre-miR negative control cells were also co-cultured with OP9-ctrl cells to evaluate the response of the ECC to DLL1. After that, cells were fixed, stained for OCT4 and imaged described before. The intensity of OCT4 staining was measured using CellProfiler and the results were compared to the cells transfected with pre-miR negative control and co-cultured with OP9-DL1.

\section{Statistical analysis}

All experiments were performed in triplicates, where $*=p \leq 0,05 ; * *=p \leq 0,01 ; * * *=p \leq 0,001$. The significances were calculated by Mann-Whitney test. GraphPad Prism 6.0 software was used for the statistical analysis. 


\section{Results}

Once both human pluripotent cell lines were transfected with each of the selected miR mimics, they underwent the labeling process to obtain the fluorescence images and were analysed for phenotypic modifications (based on the cytomorphology and expression of OCT4 and CCNB1) These quantitative data were analyzed and organized to obtain phenotypic profiles induced by the gain of function of the each one of the tested miRNAs. Several parameters were analyzed, but for the characterization of the phenotypic profile induced by each miRNA and subsequent clustering by the phenotype similarities presented, the following parameters were chosen: cell count; solidity, eccentricity, nuclear and cellular area, nuclear and cellular perimeter; medium intensity of nuclear and cytoplasmic OCT4 and CCNB1 stainings.

The data from the controls in each plate for each cell line were clusterized and demonstrated a high similarty in their comportament, as it can be seen in figures 01 and 02 . After, the clusterization from each treatment in both NTera-2 and H1 cells can be visualized in figura 03 and 04. From the 31 miRNAs tested, 25 presented concordant results between both lines (in relation to OCT4 expression), where 16 had a pro-pluripotency effect and 9, pro-differentiation. Of the other 6 discordants, 5 induced differentiation in the NTera-2 line, but not in H1, and 1 had the opposite effect (Figure 05A). Comparing the results obtained from the functional assay with the expected, it can be seen that 20 of the 25 miRNAs with concordant effects in NTera-2 and H1, 20 had an effect compatible with the literature (13 pro-pluripotency And 7 cell pro-differentiation) and another 5 behaved discordantly (Figure 05B).

According to their effects on the ECC lineage, the miRNAs studied here were divided into two major clusters, the miRNAs with pro-differentiation effects grouped in cluster A and those with pluripotency activities in cluster B. In subcluster A. 1, about 1760 mRNAs shared among the targets of these miRNAs were identified and, through the DAVID tool for functional annotation, were found in the KEGG PATHWAY Database and BIOCARTA 79 pathways potentially regulated by these miRNAs, of which the following pathways stand out: PI3K -AKT, MAPK, TNF, TGF $\beta$, WNT and signaling pathways regulating pluripotency in stem cells. For subcluster A.2, 109 shared genes and 8 pathways were detected, including the actin cytoskeleton regulation pathways and the mTOR signaling pathway. For cluster A.3, due to the fact that it consists of two variants of miR-29, more than 3,500 shared genes were found, requiring the use of a filter to be able to apply them to the DAVID tool. For this, only the unique genes of this cluster were selected when comparing the set of genes of A.3 with those of the other clusters identified and, for this, the Venny 2.1 tool was used (http://bioinfogp.cnb.csic.es/Tools/venny/). Finally, a total of 2523 genes were applied to identify pathways possibly regulated by the miRNAs of this cluster, resulting in the observation of 71 of them, among them the extracellular matrix receptors, focal adhesion, IGF-1 signaling, mTOR, PI3K-AKT, TNF, WNT and signaling pathways regulating pluripotency in stem cells. The targets of each identified subcluster A in each pathway are described in Table 01.

For cluster B, the targets and pathways possibly regulated in each subcluster were identified in the same way as for cluster A. Thus, in subcluster B.1, 338 shared genes and 11 possibly regulated pathways were observed, including the signaling pathways FOXO and RAS. As for B.2a, the identification of 896 genes shared among miRNA targets resulted in the observation of 20 possibly regulated pathways, including DICER, FOXO, mTOR, PI3K-AKT and Toll-like receptor pathways. Finally, for the subcluster B.2b, the 153 target genes shared among 
the miRNAs led to the identification of 7 pathways, being part of them the DICER pathway, VEGF and signaling pathways regulating pluripotency in stem cells. In Table 02 the target genes of the miRNAs of the different subclusters found in each of the highlighted pathways can be found.

As described previously, in the cell line derived from human CTE, transfection with the miR mimics of the miRNAs selected for the present study led to the identification of three clusters, based on the similarity between the phenotypes resulting from the treatments. For cluster A, where 455 genes shared among the targets of the miRNAs components of this cluster, 14 potentially regulated pathways were identified, including the RAS signaling pathway, actin cytoskeleton regulation and signaling pathways regulating pluripotency in cells. For cluster B, in B.1, 397 subcluster and 14-way target genes were found, comprising the RAP1 mTOR pathway and signaling pathways regulating pluripotency in stem cells; For B.2, containing only the two miR-29 variants such as the A.3 subcluster of the NTera-2 strain, the same approach was applied to filter the unique targets of these miRNAs in comparison with the other clusters, resulting in a group Of 2573 target genes and identification of 81 possibly regulated pathways, from which the extracellular matrix receptors pathway, focal adhesion, PI3K-AKT, TNF and signaling pathways regulating pluripotency in stem cells can be highlighted. Table 03 contains the information of each of the target genes of the miRNAs per cluster within the biological pathways found using the DAVID tool. For the C subclusters, in silico analyzes detected in C.1 340 genes among the shared targets, which led to the identification of 29 pathways that could be regulated by the miRNAs of this subcluster, including the DICER, FOXO, mTOR and mTOR pathways. Signaling regulating pluripotency in stem cells. In C.2a, the over 1150 target genes led to the detection of 48 possibly regulated pathways, such as: FOXO, MAPK, mTOR, TGF $\beta$, Toll-like receptor pathway and signaling pathways regulating pluripotency in stem cells. For C.2b, 791 shared target genes were found, which resulted in the identification of 59 pathways, of which the DICER, EGF, FOXO, JAK-STAT, MAPK, mTOR, PI3K-AKT, RAS and pathways Signaling regulating pluripotency in stem cells. Finally, the analysis of the shared targets among the miRNAs of the C.2c subcluster identified 277 genes, which when applied in the DAVID tool led to the identification of 19 pathways potentially regulated by these miRNAs, among them the DICER and FOXO pathways. Every pathways and targets described for each subcluster of cluster $\mathrm{C}$ are presented in Table 04 .

In order to evaluate the possible effect of the miRNAs on the level of transcripts of their targets, miRNAs representing each cluster identified by the phenotypic profiles found in both the NTera-2 and H1 were selected. The effects of miR-29b-3p on the transcripts of STAT3, RELA, LIF, KLF4, IL2RA, FGFR1, IGF1R, APC, TGFB3 were evaluated for the subunits A.3 and B.2, respectively in NTera-2 and H1. And CDKN2B and the results obtained can be seen in Figure 06. For many of these genes, a decrease in the quantification of transcript levels was observed, being this statistically significant $(\mathrm{P}<0.05)$ for KLF4 and APC. For CDKN2B, a statistically significant increase $(\mathrm{P}<0.05)$ in the quantification of its transcripts was observed unexpectedly. In Figure 07 the results obtained for the other miRs representing the phenotypic clusters of NTera- 2 and $\mathrm{H} 1$ are shown: miR-18b-5p (B.1 / B.1), miR-20a-5p (A1 / (A.2 / C1), miR-23a-3p (A.2 / C1), miR-24-3p (A.2 / B.1), miR-30a-5p (A.2 / A), miR-92a-3p B.2a / C.2c), miR-181d-5p (B.2b / C.1), miR-222-3p (B.1 / C.2b), miR-302a3p (B.2a / C .2b), miR-363-3p (B.1 / B.1), miR-371a-3p (B.2b / C.2c), miR-373-3p (B.2b / C.2a).

For GSK3B, miR-24-3p and miR-363-3p caused a reduction in the quantification of transcripts, this reduction being statistically significant $(\mathrm{P}<0.05)$ only for the first miRNA cited, while miR-18b-5p led To a statistically significant increase in this quantification. For SMAD2, only miR-18b-5p caused a statistically significant (P 
$<0.05$ ) reduction at the transcriptional level, although an effect caused by miR-24-3p and 373-3p was also observed. Regarding TGFBR2 levels, miR-20a-5p, miR-222-3p and miR-373-3p caused a decrease $(\mathrm{P}<0.05)$ in quantifications by qPCR. Reductions in the quantification of MAPK1 by miR-30a-5p, miR-181d-5p and miR373-3p, of TCF3 by miR-24-3p, of PTEN by miR-181d-5p, and of FGF2 by miR -20a-5p, all of these reductions being statistically significant $(\mathrm{P}<0.05)$. For the CDK6, BMPR2 and IL6ST genes no changes were detected caused by the treatments with the miR mimics tested.

In order to investigate the possible regulatory effect of miRNAs that promoted pluripotency in the functional assay on the Notch pathway, we initially identified the pathway components in the database KEGG. Once the genes of these components were identified, the miRNAs (from the set studied here) were identified that targeted these transcripts. Table 05 presents the results of this analysis, describing the pathway genes and the miRNAs that target them.

The functional assay, performed with NTera-2 lineage cells transfected with selected miRNAs and cocultivated with the OP9-DL1 or OP9-Ctrl line, are shown in Figure 8. By the change in the amount of nuclear OCT4, reflected by the fluorescence intensity of the label, It was seen that the induction of Notch by DLL1 caused cell differentiation in the CCE (A) line, since the presence of OP9-DL1 led to a reduction of approximately $20 \%$ in the amount of nuclear OCT4 $(\mathrm{P}<0), 0001)$. As for the inhibitory effect of the Notch pathway, resulting in maintenance of pluripotency, it was only observed by miR-363-3p (B), and transfection with this miR mimic maintained a $19 \%$ higher nuclear OCT4 quantification than in the control $(\mathrm{P}=0.0022)$. In fact, this miRNA caused a reduction in NOTCH2 $(\sim 15 \%, \mathrm{C})$ and PSEN1 $(\sim 56 \%, \mathrm{P}<0.05, \mathrm{D})$ transcripts, whereas no effect was observed by other miRNA (miR-18b) targeting The mRNA of these Notch components.

\section{Discussion}

NTera-2 and H1 as pluripotency study models

The CTE and CCE lines present a great similarity in the pattern of gene expression (SPERGER et al., 2003), similarities that are also observed when comparing the proteomic profile of cells from both origins, where markers known as CTE have protein levels Very close in CCE, such as LIN28 and THY. In addition, the CTE present a higher amount of the proteins DNMT3B and CTNNB1, whereas CEC present high levels of some proteins related to some types of cancer (CHAERKADY et al., 2010; DORMEYER Et al., 2008). In the miRNA function gain assays performed in the present work, some differences in response between the H1 and NTera-2 lines were detected. Of the 31 miRNAs studied, 25 presented similar results and the remaining 6 reacted opposite. Given the differences between CTE and CCE presented previously, it can be said that there was a great agreement between the responses of the cells to the treatments, which values the data found, demonstrating robustness in the assay developed and presented here.

From the group of divergent miRNAs, 5 of them induced phenotypic changes consistent with loss of pluripotency in NTera-2, but not in H1, being miR-19a-3p, miR-19b-3p, miR-20a-5p, miR-20b -5p and miR-21$5 \mathrm{p}$. In fact, a slight increase in the expression of the first four miRNAs reported in cultures of NTRA-2 treated with atRA (SEMPERE et al., 2004) is reported in the literature. Similarly, induction of differentiation in CTE also results in a higher level of miR-21-5p expression (GU et al., 2016; STADLER et al., 2010). 
In contrast, miR-17-5p induced an increase in the intensity of OCT4 in the nucleus of NTera-2 cells, whereas, for the H1 lineage, there was a slight reduction in this parameter. Although this microRNA is repressed in CTEh under differentiation (STADLER et al., 2010), our results are in line with literature data, which showed a prodifferentiation effect of miR-17-5p in CTE, as well as miR- 20a-5p; In the latter case, different from our results for the H1 lineage (GU et al., 2016). MiR-17-5p is found at high levels in undifferentiated NTera-2, as well as in other malignant tumor types (GALLAGHER et al., 2009); Thus, the opposite effects of this miR in both strains may arise from differences concerning aberrant pathways present in the SCC.

For the most part, the observed functional effects of the miRNAs evaluated corroborated the expected effects, considering the hypotheses underlying the selection criterion described in Table 1; More specifically, that microRNAs highly expressed in pluripotent and / or repressed cells by differentiation would be functionally associated with maintenance of pluripotency, whereas microRNAs induced during differentiation would be involved in opposing processes. In fact, only 5 of the miRNA had an unexpected response (Figure 19B). Among these, miR-18a-5p, which despite its pluripotent behavior in the work of Stadler et al. (2010), showed increased levels in the differentiation process of CTE for pancreatic beta cells (COSKUN; ERCIN; GEZGINCIOKTAYOGLU, 2017).

For miR-145-5p, the result was unexpected because, under the conditions used here, it promoted characteristics compatible with pluripotency, but this miRNA is known to be involved in the induction of cell differentiation, having increased levels during this process and negatively regulating the Translation of OCT4, SOX2 and KLF4 (XU et al., 2009). Moreover, the use of the inhibitor of this miRNA has a positive effect on the nuclear reprogramming, increasing the efficiency of obtaining iPSC (BARTA et al., 2016). These conflicting results may come from the different methods used to evaluate miR-145-5p function gain, since we used the transfection of mimetic molecules (and therefore, with a transient repressive effect), whereas $\mathrm{Xu}$ and co-workers transduced The cells with lentiviral vectors, evaluating the isolated population overexpressing the microRNA. Thus, the extremely high and constantly high levels of this miR in the CTE may have a different net effect on their targets. Two other miRNAs that exhibited a pluripotency activity in the functional assays, having the opposite effect to that expected in Stadler et al. (2010), were miR-181d-5p and miR-222-3p. For the first, it is described in the literature that, the gain of function of this miRNA promotes improvement in OSK-induced nuclear reprogramming efficiency (OCT4, SOX, KLF4), and all miRs of the miR-181 family are induced during reprogramming Mediated by OSK, being repressed in the generated iPSCs (JUDSON et al., 2013). Further, the miR-181c \& d locus promoter is ligated by OCT4, SOX2 and NANOG, being induced during reprogramming mediated by OSK and cMyc, while miR-181a and miR-181b are repressed (CHEN et al., 2012a). Thus, although the microRNA induction of miR-181 is involved in the differentiation of muscle cells (NAGUIBNEVA et al., 2006) and B lymphocytes (CHEN, 2004), Stadler et al. That its performance may have a distinct role associated with pluripotency in certain situations. In addition, the miRNA is related to adult stem cells (MATHIEU; RUOHOLA-BAKER, 2013; REN et al., 2009), and is also associated with complete terminal differentiation of myocytes (CARDINALLI et al. Al., 2009), again revealing the flexibility of the role mediated by particular microRNAs in different contexts.

miRNAs that regulate the RISC complex promote phenotypic profiles associated with pluripotency in human pluripotent cells 
miRNAs play important roles in the most diverse biological processes, be they physiological or pathological, including maintenance of pluripotent phenotype and cell differentiation (ANOKYE-DANSO et al., 2011; LAKSHMIPATHY et al). In order to better understand the role of these regulatory RNAs in pluripotent cells, knockout CTE lines were produced for DICER or DGCR8, which works together with Drosha (KANELLOPOULOU et al., 2005; WANG et al., 2007). Although these cells were not competent to generate functional miRNAs, they remained viable and expressed the pluripotency markers. However, with the absence of mature miRNAs, these CTE showed changes in the time of duplication, becoming slower, and lost their capacity for cell differentiation, since they failed to generate chimeras, teratomas or cells of the embryonic leaflets in vitro, by the techniques of bodies Embryoids. They also showed slow response to the differentiation stimulus, with slow loss of pluripotency markers. This set of results demonstrated that miRNAs, although they play important roles in pluripotent cells, are not indispensable for the maintenance of the undifferentiated phenotype, but for cell differentiation.

In this sense, the functional assay allowed the observation of groups of miRNAs that promoted pluripotency characteristics, and the analysis of the targets shared between them and the possible routes regulated by them resulted in the identification of the Dicer pathway as probably modulated. Ago transcripts are targets of the miRNAs of these clusters (in NTera-2: B.2a and B.2b, in H1: C.1, C.2b and C.2c), which include, among others, miRs-302 And those of the miR-371 cluster, which are highly expressed in human pluripotent cells (LAKSHMIPATHY; DAVILA; HART, 2010; STADLER et al., 2010; SUBRAMANYAM et al., 2011). It is known that the Ago proteins are extremely important for miRISC assembly and are crucial for the activity of the miRNAs (WANG et al., 2012), a hypothetical knockdown of these proteins caused by the miRNAs with pluripotency could lead to a reduction Of the availability of RISC to associate with miRNAs that would act to induce cellular differentiation without compromising the pluripotent phenotype. This mechanism becomes a real possibility, since the regulation mediated by these small RNAs is highly quantitative in nature and depends on the cytoplasmic concentrations of the miRNAs in question and their targets (MUKHERJI et al., 2011).

Regulation of PI3K-AKT and mTOR by miRNAs may induce cell differentiation or pluripotency-related characteristics in human stem cells

Within the pathways identified as possibly regulated by the different phenotypic clusters of miRNAs studied, there are PI3K-AKT, mTOR, FOXO and RAS pathways, some of them detected in both the pro and antipluripotency miRNA groups. PI3K-AKT and mTOR signaling pathways are known to act in several important processes in cellular functions, such as anabolic reactions, cell growth and survival, and the loss of key components of these pathways may lead to life incompatibility (MURAKAMI et al. (2001) and YU et al., 2005b). In CTE, inhibition of PI3K results in the loss of pluripotency characteristics and expression of genes related to cellular compromise (ARMSTRONG et al., 2006; MCLEAN et al., 2007; SINGH et al., 2012) and PTEN knockout, Which acts against PI3K, has a positive effect on the proliferation and survival of these cells (Alva et al., 2011). In CTEh, the proposed PI3K pluripotency maintenance mechanism seems to be related not only to inhibition of MAPK / ERK, but also to the suppression of $\beta$-catenin activity by GSK3 activation, since $\beta$ - 
catenin participates in gene expression Related to cell differentiation (DAVIDSON et al., 2012; SINGH et al., 2012).

The mTOR pathway has also been related to pluripotent status, and its inhibition leads to the loss of pluripotency in CTEh, whereas the knockdown of pathway physiological suppressors prevents cell differentiation (BETSCHINGER et al., 2013; ZHOU et al. 2009). This pathway acts in conjunction with PI3K-AKT to regulate aerobic glycolytic metabolism, stimulating the expression of glucose transporters and glycolytic enzymes, although it is also involved in the production of proteins involved in mitochondrial function and oxidative metabolism (CHENG et al. In the present study, the results of this study are presented in Table 1. Thus, these pathways participate in the maintenance of pluripotency also by the regulation of cellular metabolism, the anaerobic glycolytic pathway being the main energy provider in pluripotent cells, being rapidly replaced by oxidative phosphorylation when these cells are submitted to a differentiation stimulus (MOUSSAIEFF et al. , ZHOU et al., 2012b).

Within clusters that induced cell differentiation in both strains used in the present study (in NTera-2: A.1, A.2 and A.3; in H1: B.2), the PI3K-AKT and mTOR pathways were found As possibly regulated. In addition, several studies have reported on the control of miRNAs on PI3K / AKT / mTOR (BAI et al., 2015, JIANG et al., 2017; JOSSE et al., 2014), and some representatives of the phenotypic clusters in question , Such as miR-27a-3p, miRs-29a / b-3p and miR-30a-5p, act directly on transcripts of components of these pathways, inhibiting them in different human cell models (LIU et al., 2013; MENG Et al., 2016, YANG et al., 2013, YU et al., 2015a, ZHONG, BIAN, WU, 2013). In addition, the IGF-1 pathway, which acts as a PI3K-inducer and maintenance of pluripotency (HUANG et al., 2009; SINGH et al., 2012), is inhibited by the action of miRs-29 HAND et al., 2012; WANG et al., 2015c), and was identified by the functional assay (performed in the present study) as possibly regulated in the cluster by miRs-29a / b-3p, by inhibiting IGF1 itself, which (Insulin receptor, which can activate PI3K), GAP (GTPase-activating proteins), and c-FOS (pathway-activated transcription factor). That said, the inhibition of these pathways could by miRNAs may be one of the mechanisms by which they induce differentiation in human pluripotent cells.

Some of the phenotypic clusters of miRNAs that induced pluripotency characteristics also showed a possible modulation of the PI3K-AKT and mTOR pathways (in NTera-2: B2.a; in H1: B.1, C.1, C.2a, and C. 2b). Within the targets detected in the pathways is the PTEN tumor suppressor, which is a PI3K-AKT antagonist. In addition, the miR-222-3p, a component of the phenotypic cluster C.2b of the H1 lineage, has inhibitory activity on PTEN, thus acting as an onco-miR (CHUN-ZHI et al., 2010; SHEN et al., 2017; WANG et al. Al., 2016). In the present study, the microRNA assay was carried out in the presence of a microenvironment in the H1-M1 clone, and the MR-181d-5p, representative of the C.1 cluster in H1, induced pluripotency, also induces inhibitory activity on this tumor suppressor (HENAO-MEJIA et al. PTEN when transfected into the NTera-2 lineage (Figure 37). Together, these data corroborate a hypothesis of pluripotency promotion by the miRNAs of clusters with pro pluripotency activity, detected as modulating the signaling pathways in question, through the inhibition of PTEN.

Inhibition of the Notch pathway by miRNAs promotes pluripotency in embryonic stem cells and human embryonic carcinoma cells 
Notch signaling is a conserved pathway that plays a very important role in the control of cell fate and embryonic development in animals, from drosophila to human (ARTAVANIS-TSAKONAS; RAND; LAKE, 1999). Activation of this pathway occurs through the interaction of ligands, such as DLL1, which interact with the NOTCH protein, thus recruiting a gamma-secretase, of which PSEN1 is a subunit. The gamma-secretase action releases the internal NOTCH domain, which goes to the nucleus and complexes with RBPJ, a DNA-binding protein, thus inducing the expression of pathway effector genes, such as HES1 (KAGEYAMA; OHTSUKA KOBAYASHI, 2007). In addition, the activation of Notch leads to cell differentiation, mainly by the action of HES1, which participates in the formation of several cell types due to its cyclic and oscillatory behavior, resulting from a negative feedback of HES1 on Notch (KOBAYASHI et al., 2009 KOBAYASHI, KAGEYAMA, 2010, YU et al., 2008).

Once we know the role of this pathway on differentiation in human pluripotent cells, we then try to verify if the inhibition of Notch would be a possible mechanism of the promotion of pluripotency characteristics observed in the phenotypic clusters. Thus, the targets of the miRNAs studied here were compared with the list of components of the Notch pathway, which resulted in the identification of three miRNAs with a large number of targets in the pathway, namely miR-302c-3p, miR-92a-3p And miR-363-33, with 17, 12 and 12 targets, respectively. Two other miRNAs, miR-222-3p and miR-371a-3p, which also promoted pluripotency in NTera-2 and H1, were identified with few targets in the pathway (5 and 1 targets, respectively). In this line of reasoning, it was decided to verify the ability of these miRNAs to inhibit Notch-induced cell differentiation, with only miR-363-3p being shown to be effective in maintaining a higher amount of nuclear OCT4 in OPC-1, And the same miRNA was shown to cause a significant reduction in PSEN1 transcript levels.

It is known that miRNAs can regulate the Notch pathway in different situations (BU et al., 2013, ORTEGA et al., 2015, WON et al., 2013), demonstrating the repressive action of miR-363-3p on this pathway by However, the role of miRNAs directly in the regulation of Notch in pluripotent cells has not yet been explored and the implications of this regulation are unknown. With the data generated here and together with the existing literature knowledge, it is possible to hypothesize a mechanism of regulation of pluripotency by action of miR363-3p, where it represses the activation of the Notch pathway by knockdown of components of this pathway, as PSEN1 and NOTCH, thus preventing the inducing effect of differentiation performed by HES1 and promoting self renewal and maintenance of pluripotent status. This same mechanism may apply to other non-Notch-related miRNAs in human pluripotent cells.

Inhibition of the components of the Notch pathway can still be related to a reprogramming of a "primate" state to a "naive", since cells in this more undifferentiated state do not present NOTCH receptors on their membranes (COLLIER et al., 2017) . Following the same reasoning, a study in which cellular subpopulations were evaluated in CTEh cultures revealed the existence of cells with similar characteristics to naive, which although expressing OCT4 and NANOG, had low expression of SSEA4 and TRA-1-81, and were resistant to Differentiation induced by atRA. In this population, a small expression of components of the Notch pathway was observed, whereas in the population with concordant characteristics with primitive cells they had high levels of these (ANNAB et al., 2012). Thus, an additional reprogramming mechanism for a naive pluripotent state governed by miRNAs such as miR-363-3p can be proposed.

\section{Acknowledgments}


This work was supported by Fundação de Amparo à Pesquisa do Estado de São Paulo (FAPESP) and Conselho Nacional de Desenvolvimento Científico e Tecnológico (CNPq), Brazil.

\section{Author disclosure statement}

No competing financial interests exist.

\section{References}

ALVA, J. A. et al. Phosphatase and tensin homolog regulates the pluripotent state and lineage fate choice in human embryonic stem cells. Stem cells (Dayton, Ohio), v. 29, n. 12, p. 1952-62, dez. 2011.

ANNAB, L. A. et al. Differential responses to retinoic acid and endocrine disruptor compounds of subpopulations within human embryonic stem cell lines. Differentiation; research in biological diversity, v. 84, n. 4, p. 330-43, nov. 2012.

ANOKYE-DANSO, F. et al. Highly efficient miRNA-mediated reprogramming of mouse and human somatic cells to pluripotency. Cell stem cell, v. 8, n. 4, p. 376-88, 8 abr. 2011.

ARMSTRONG, L. et al. The role of PI3K/AKT, MAPK/ERK and NFkappabeta signalling in the maintenance of human embryonic stem cell pluripotency and viability highlighted by transcriptional profiling and functional analysis. Human molecular genetics, v. 15, n. 11, p. 1894-913, 1 jun. 2006.

ARTAVANIS-TSAKONAS, S.; RAND, M. D.; LAKE, R. J. Notch signaling: cell fate control and signal integration in development. Science (New York, N.Y.), v. 284, n. 5415, p. 770-6, 30 abr. 1999.

BAI, L. et al. MicroRNA-21 Regulates PI3K/Akt/mTOR Signaling by Targeting TGF $\beta$ I during Skeletal Muscle Development in Pigs. PloS one, v. 10, n. 5, p. e0119396, 2015.

BARTA, T. et al. Inhibition of miR-145 Enhances Reprogramming of Human Dermal Fibroblasts to Induced Pluripotent Stem Cells. Stem Cells, v. 34, p. 246-251, 2016.

BETSCHINGER, J. et al. Exit from pluripotency is gated by intracellular redistribution of the bHLH transcription factor Tfe3. Cell, v. 153, n. 2, p. 335-47, 11 abr. 2013.

BOYER, L. A. et al. Core Transcriptional Regulatory Circuitry in Human Embryonic Stem Cells. v. 122, n. Icm, p. 947-956, 2005.

BU, P. et al. A microRNA miR-34a-regulated bimodal switch targets Notch in colon cancer stem cells. Cell stem cell, v. 12, n. 5, p. 602-15, 2 maio 2013.

BUENO, M. J.; MALUMBRES, M. MicroRNAs and the cell cycle. Biochimica et Biophysica Acta - Molecular Basis of Disease, v. 1812, n. 5, p. 592-601, 2011.

CARDINALLI, B. et al. Microrna-221 and microrna-222 modulate differentiation and maturation of skeletal muscle cells. PLoS ONE, v. 4, n. 10, 2009.

CARLETON, M.; CLEARY, M. A.; LINSLEY, P. S. MicroRNAs and cell cycle regulation. Cell Cycle, v. 6, n. 17, p. 2127-2132, 2007. 
CHAERKADY, R. et al. Comparative proteomics of human embryonic stem cells and embryonal carcinoma cells. Proteomics, v. 10, n. 7, p. 1359-73, abr. 2010.

CHEN, C.-Z. MicroRNAs Modulate Hematopoietic Lineage Differentiation. Science, v. 303, n. 5654, p. 83-86, 2004.

CHEN, J. et al. Synergetic cooperation of microRNAs with transcription factors in iPS cell generation. PloS one, v. 7, n. 7, p. e40849, 2012.

CHENG, S.-C. et al. mTOR- and HIF-1 $\alpha$-mediated aerobic glycolysis as metabolic basis for trained immunity. Science (New York, N.Y.), v. 345, n. 6204, p. 1250684, 26 set. 2014.

CHUN-ZHI, Z. et al. MicroRNA-221 and microRNA-222 regulate gastric carcinoma cell proliferation and radioresistance by targeting PTEN. BMC Cancer, v. 10, p. 367, 2010.

COLliER, A. J. et al. Comprehensive Cell Surface Protein Profiling Identifies Specific Markers of Human Naive and Primed Pluripotent States. Cell stem cell, v. 20, n. 6, p. 874-890.e7, 1 jun. 2017.

COSKUN, E.; ERCIN, M.; GEZGINCI-OKTAYOGLU, S. The Role of Epigenetic Regulation and Pluripotency-Related MicroRNas in Differentiation of Pancreatic Stem Cells to Beta Cells. Journal of cellular biochemistry, n. June, 9 jun. 2017.

DAVIDSON, K. C. et al. Wnt/ $\beta$-catenin signaling promotes differentiation, not self-renewal, of human embryonic stem cells and is repressed by Oct4. Proceedings of the National Academy of Sciences of the United States of America, v. 109, n. 12, p. 4485-90, 20 mar. 2012.

DORMEYER, W. et al. Plasma membrane proteomics of human embryonic stem cells and human embryonal carcinoma cells. J Proteome Res, v. 7, n. 7, p. 2936-2951, 2008.

GALLAGHER, M. F. et al. Regulation of microRNA biosynthesis and expression in 2102Ep embryonal carcinoma stem cells is mirrored in ovarian serous adenocarcinoma patients. Journal of Ovarian Research, v. 2 , n. 1, p. 19, 2009.

GRISHOK, A. et al. Genes and mechanisms related to RNA interference regulate expression of the small temporal RNAs that control C. elegans developmental timing. Cell, v. 106, n. 1, p. 23-34, 2001.

GU, K.-L. et al. Pluripotency-associated miR-290/302 family of microRNAs promote the dismantling of naive pluripotency. Cell Research, v. 26, n. 3, p. 350-366, 2016.

GUO, H. et al. Mammalian microRNAs predominantly act to decrease target mRNA levels. Nature, v. 466, n. 7308, p. 835-40, 12 ago. 2010.

HAN, J. et al. The Drosha - DGCR8 complex in primary microRNA processing. Genes \& Development, p. 3016-3027, 2004.

HAND, N. J. et al. MicroRNA profiling identifies miR-29 as a regulator of disease-associated pathways in experimental biliary atresia. Journal of pediatric gastroenterology and nutrition, v. 54, n. 2, p. 186-92, fev. 2012.

HENAO-MEJIA, J. et al. The microRNA miR-181 is a critical cellular metabolic rheostat essential for NKT cell ontogenesis and lymphocyte development and homeostasis. Immunity, v. 38, n. 5, p. 984-97, 23 maio 2013. 
HOUBAVIY, H. B.; MURRAY, M. F.; SHARP, P. A. Embryonic stem cell-specific MicroRNAs. Developmental cell, v. 5, n. 2, p. 351-358, 2003.

HUANG, Y.-H. et al. Pluripotency of mouse spermatogonial stem cells maintained by IGF-1- dependent pathway. The FASEB Journal, v. 23, n. 7, p. 2076-2087, 2009.

HUTVÁGNER, G. et al. A cellular function for the RNA-interference enzyme Dicer in the maturation of the let7 small temporal RNA. Science (New York, N.Y.), v. 293, n. 5531, p. 834-838, 2001.

IVEY, K. N.; SRIVASTAVA, D. MicroRNAs as regulators of differentiation and cell fate decisions. Cell Stem Cell, v. 7, n. 1, p. 36-41, 2010.

JIANG, W. et al. MicroRNA-Related Polymorphisms in PI3K/Akt/mTOR Pathway Genes Are Predictive of Limited-Disease Small Cell Lung Cancer Treatment Outcomes. BioMed research international, v. 2017, p. 6501385, 2017.

JOSSE, C. et al. Identification of a microRNA landscape targeting the PI3K/Akt signaling pathway in inflammation-induced colorectal carcinogenesis. American journal of physiology. Gastrointestinal and liver physiology, v. 306, n. 3, p. G229-43, fev. 2014.

JUDSON, R. L. et al. Embryonic stem cell-specific microRNAs promote induced pluripotency. Nature biotechnology, v. 27, n. 5, p. 459-61, maio 2009.

JUDSON, R. L. et al. MicroRNA-based discovery of barriers to dedifferentiation of fibroblasts to pluripotent stem cells. Nature structural \& molecular biology, v. 20, n. 10, p. 1227-35, out. 2013.

KAGEYAMA, R.; OHTSUKA, T.; KOBAYASHI, T. The Hes gene family: repressors and oscillators that orchestrate embryogenesis. Development, v. 134, n. 7, p. 1243-1251, 2007.

KANELLOPOULOU, C. et al. Dicer-deficient mouse embryonic stem cells are defective in differentiation and centromeric silencing. Genes and Development, v. 19, n. 4, p. 489-501, 2005.

KIM, J. et al. HIF-1-mediated expression of pyruvate dehydrogenase kinase: a metabolic switch required for cellular adaptation to hypoxia. Cell metabolism, v. 3, n. 3, p. 177-85, mar. 2006.

KOBAYASHI, T. et al. The cyclic gene Hes1 contributes to diverse differentiation responses of embryonic stem cells. Genes and Development, v. 23, n. 16, p. 1870-1875, 2009.

KOBAYASHI, T.; KAGEYAMA, R. Hes1 regulates embryonic stem cell differentiation by suppressing Notch signaling. Genes to Cells, v. 15, n. 7, p. 689-698, 2010.

LAKSHMIPATHY, U. et al. MicroRNA expression pattern of undifferentiated and differentiated human embryonic stem cells. Stem cells and development, v. 16, n. 6, p. 1003-16, dez. 2007.

LAKSHMIPATHY, U.; DAVILA, J.; HART, R. P. miRNA in pluripotent stem cells. Regenerative medicine, v. 5, n. 4, p. 545-55, jul. 2010.

LAURENT, L. C. et al. Comprehensive microRNA profiling reveals a unique human embryonic stem cell signature dominated by a single seed sequence. Stem cells (Dayton, Ohio), v. 26, n. 6, p. 1506-16, jun. 2008.

LEE, R. C.; FEINBAUM, R. L.; AMBROS, V. The C. elegans heterochronic gene lin-4 encodes small RNAs with antisense complementarity to lin-14. Cell, v. 75, n. 5, p. 843-854, 1993. 
LIU, G. et al. MiR-27a regulates apoptosis in nucleus pulposus cells by targeting PI3K. PloS one, v. 8, n. 9, p. e75251, 2013.

LÜNINGSCHRÖR, P. et al. MicroRNAs in pluripotency, reprogramming and cell fate induction. Biochimica et Biophysica Acta - Molecular Cell Research, v. 1833, n. 8, p. 1894-1903, 2013.

MALLICK, B.; CHAKRABARTI, J.; GHOSH, Z. MicroRNA reins in embryonic and cancer stem cells. RNA biology, v. 8, n. 3, p. 415-26, 1 maio 2011.

MARSON, A. et al. Connecting microRNA Genes to the Core Transcriptional Regulatory Circuitry of Embryonic Stem Cells. Cell, v. 134, n. 3, p. 521-533, 2008.

MATHIEU, J.; RUOHOLA-BAKER, H. Regulation of stem cell populations by microRNAs. Advances in experimental medicine and biology, v. 786, p. 329-51, 2013.

MCLEAN, A. B. et al. Activin a efficiently specifies definitive endoderm from human embryonic stem cells only when phosphatidylinositol 3-kinase signaling is suppressed. Stem cells (Dayton, Ohio), v. 25, n. 1, p. 2938, jan. 2007.

MENG, F. et al. MiR-30a-5p overexpression may overcome EGFR-inhibitor resistance through regulating PI3K/AKT signaling pathway in non-small cell lung cancer cell lines. Frontiers in Genetics, v. 7, n. NOV, p. 1$10,2016$.

MENG, X. et al. Inhibition of miR-363 protects cardiomyocytes against hypoxia-induced apoptosis through regulation of Notch signaling. Biomedicine \& pharmacotherapy = Biomedecine $\&$ pharmacotherapie, v. 90, p. 509-516, jun. 2017.

MORITA, M. et al. mTORC1 controls mitochondrial activity and biogenesis through 4E-BP-dependent translational regulation. Cell metabolism, v. 18, n. 5, p. 698-711, 5 nov. 2013.

MOUSSAIEFF, A. et al. Glycolysis-mediated changes in acetyl-CoA and histone acetylation control the early differentiation of embryonic stem cells. Cell Metabolism, v. 21, n. 3, p. 392-402, 2015.

MUKHERJI, S. et al. MicroRNAs can generate thresholds in target gene expression. Nature genetics, v. 43, n. 9, p. 854-9, 21 ago. 2011.

MURAKAMI, M. et al. mTOR is essential for growth and proliferation in early mouse embryos and embryonic stem cells. Molecular and cellular biology, v. 24, n. 15, p. 6710-8, ago. 2004.

NAGUIBNEVA, I. et al. The microRNA miR-181 targets the homeobox protein Hox-A11 during mammalian myoblast differentiation. Nature Cell Biology, v. 8, n. 3, p. 278-284, 2006.

ORTEGA, M. et al. A microRNA-mediated regulatory loop modulates NOTCH and MYC oncogenic signals in B- and T-cell malignancies. Leukemia, v. 29, n. 4, p. 968-76, 5 abr. 2015.

PENG, X. DING et al. Dwarfism, impaired skin development, skeletal muscle atrophy, delayed bone development, and impeded adipogenesis in mice lacking Akt1 and Akt2. Genes and Development, v. 17, n. 11, p. 1352-1365, 2003.

REN, J. et al. MicroRNA and gene expression patterns in the differentiation of human embryonic stem cells. Journal of translational medicine, v. 7, p. 20, jan. 2009. 
SAYED, D.; ABDELlATIF, M. MicroRNAs in Development and Disease. Physiological Reviews, v. 91, n. 3, p. 827-887, 2011.

SEMPERE, L. F. et al. Expression profiling of mammalian microRNAs uncovers a subset of brain-expressed microRNAs with possible roles in murine and human neuronal differentiation. Genome biology, v. 5, n. 3, p. R13, 2004.

SHEN, H. et al. MiR-222 promotes drug-resistance of breast cancer cells to adriamycin via modulation of PTEN/Akt/FOXO1 pathway. Gene, v. 596, p. 110-118, 2017.

SHERMAN, S. P. et al. Human pluripotent stem cells: the development of high-content screening strategies. Methods in molecular biology (Clifton, N.J.), v. 767, p. 283-95, 2011.

SINGH, A. M. et al. Signaling network crosstalk in human pluripotent cells: A Smad2/3-regulated switch that controls the balance between self-renewal and differentiation. Cell Stem Cell, v. 10, n. 3, p. 312-326, 2012.

SIOMI, H.; SIOMI, M. C. Posttranscriptional Regulation of MicroRNA Biogenesis in Animals. Molecular Cell, v. 38, n. 3, p. 323-332, 2010.

SONG, B. et al. Tumor Suppressor Role of miR-363-3p in Gastric Cancer. Medical science monitor: international medical journal of experimental and clinical research, v. 21, p. 4074-80, 28 dez. 2015.

SPERGER, J. M. et al. Gene expression patterns in human embryonic stem cells and human pluripotent germ cell tumors. Proceedings of the National Academy of Sciences of the United States of America, v. 100, n. 23, p. $13350-5,2003$.

STADLER, B. et al. Characterization of microRNAs involved in embryonic stem cell states. Stem cells and development, v. 19, n. 7, p. 935-50, jul. 2010.

SU, Z. et al. MicroRNAs in apoptosis, autophagy and necroptosis. Oncotarget, v. 6, n. 11, p. 8474-90, 2015.

SUBRAMANYAM, D. et al. Multiple targets of miR-302 and miR-372 promote reprogramming of human fibroblasts to induced pluripotent stem cells. Nature biotechnology, v. 29, n. 5, p. 443-8, maio 2011.

TAKAHASHI, K.; YAMANAKA, S. Induction of Pluripotent Stem Cells from Mouse Embryonic and Adult Fibroblast Cultures by Defined Factors. Cell, v. 126, n. 4, p. 663-676, ago. 2006.

THOMSON, J. A. et al. Embryonic stem cell lines derived from human blastocysts. Science (New York, N.Y.), v. 282, n. 5391, p. 1145-7, 6 nov. 1998.

WANG, D. et al. Quantitative functions of Argonaute proteins in mammalian development. Genes \& development, v. 26, n. 7, p. 693-704, 1 abr. 2012.

WANG, D. DAN et al. miR-222 induces Adriamycin resistance in breast cancer through PTEN/Akt/p27kip1 pathway. Tumor Biology, v. 37, n. 11, p. 15315-15324, 2016.

WANG, L. et al. After Myocardial Ischemia-Reperfusion, miR-29a, and Let7 Could Affect Apoptosis through Regulating IGF-1. BioMed research international, v. 2015, p. 245412, 2015.

WANG, Y. et al. DGCR8 is essential for microRNA biogenesis and silencing of embryonic stem cell selfrenewal. Nature genetics, v. 39, n. 3, p. 380-5, mar. 2007. 
WARD, P. S.; THOMPSON, C. B. Signaling in control of cell growth and metabolism. Cold Spring Harbor perspectives in biology, v. 4, n. 7, p. a006783, 1 jul. 2012.

WIENHOLDS, E.; PLASTERK, R. H. A. MicroRNA function in animal development. FEBS Letters, v. 579, n. 26, p. 5911-5922, 2005.

WON, K. Y. et al. MicroRNA-199b-5p is involved in the Notch signaling pathway in osteosarcoma. Human Pathology, v. 44, n. 8, p. 1648-1655, 2013.

XU, N. et al. MicroRNA-145 regulates OCT4, SOX2, and KLF4 and represses pluripotency in human embryonic stem cells. Cell, v. 137, n. 4, p. 647-58, 15 maio 2009.

YANG, T. et al. MiR-29 mediates TGFß1-induced extracellular matrix synthesis through activation of PI3KAKT pathway in human lung fibroblasts. Journal of Cellular Biochemistry, v. 114, n. 6, p. 1336-1342, 2013.

YU, J. et al. Suppression of type I collagen expression by miR-29b via PI3K, Akt, and Sp1 pathway, part II: An in vivo investigation. Investigative Ophthalmology and Visual Science, v. 56, n. 10, p. 6019-6028, 2015a.

YU, J. S. L. et al. PI3K/mTORC2 regulates TGF- $\beta /$ Activin signalling by modulating Smad2/3 activity via linker phosphorylation. Nature Communications, v. 6, n. May, p. 7212, $2015 \mathrm{~b}$.

YU, J. S. L.; CUI, W. Proliferation, survival and metabolism: the role of PI3K/AKT/mTOR signalling in pluripotency and cell fate determination. Development, v. 143, n. 17, p. 3050-3060, 2016.

YU, X. et al. Notch Signaling Activation in Human Embryonic Stem Cells Is Required for Embryonic, but Not Trophoblastic, Lineage Commitment. Cell Stem Cell, v. 2, n. 5, p. 461-471, 2008.

ZHONG, M.; BIAN, Z.; WU, Z. MiR-30a suppresses cell migration and invasion through downregulation of PIK3CD in colorectal carcinoma. Cellular Physiology and Biochemistry, v. 31, n. 2-3, p. 209-218, 2013.

ZHOU, J. et al. mTOR supports long-term self-renewal and suppresses mesoderm and endoderm activities of human embryonic stem cells. Proceedings of the National Academy of Sciences of the United States of America, v. 106, n. 19 , p. $7840-5,12$ maio 2009.

ZHOU, W. et al. HIF1 $\alpha$ induced switch from bivalent to exclusively glycolytic metabolism during ESC-toEpiSC/hESC transition. The EMBO journal, v. 31, n. 9, p. 2103-16, 2 maio 2012. 
Figure 01

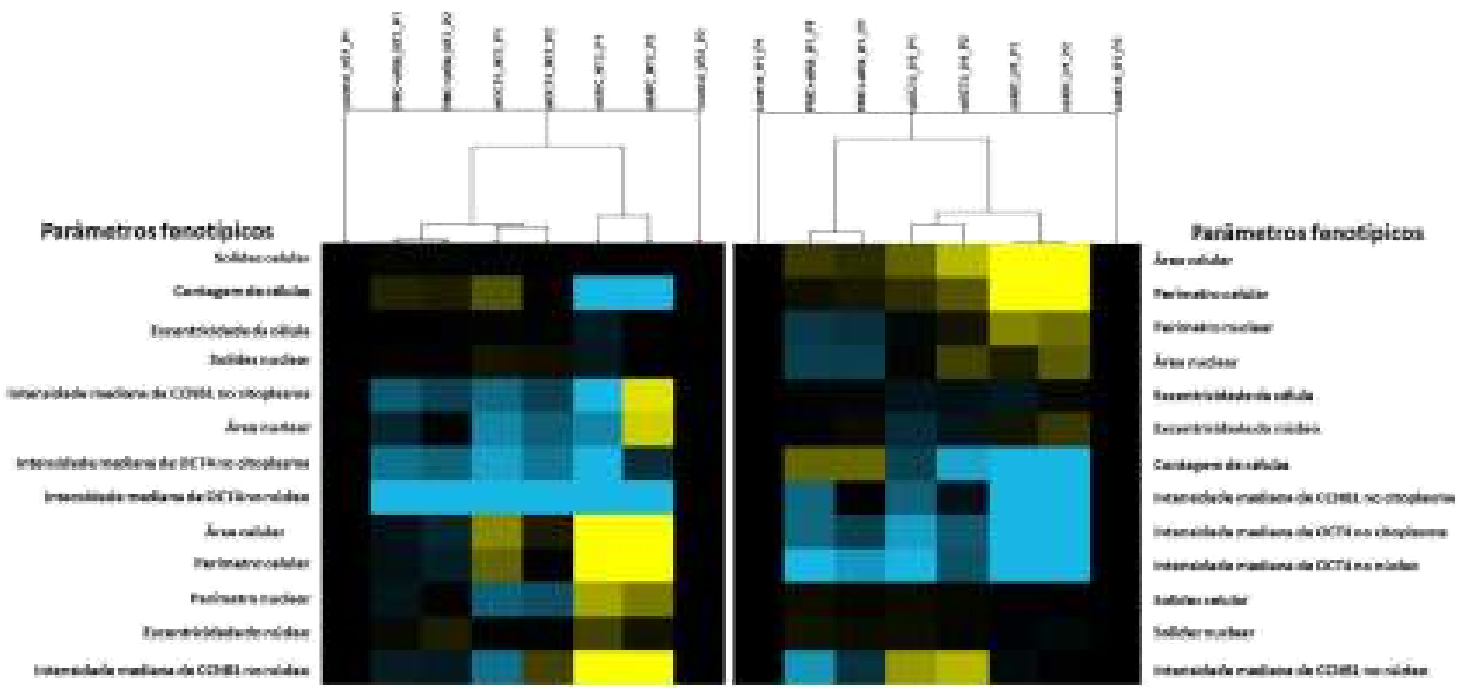

Figure 01. Clustering from the evaluation of the phenotypic effects induced by each control treatment on the two different plaques (P1 and P2) constituting the assays to study the miRNAs selected in the two pluripotent strains, NTera-2 (NT2, figure on the left) and H1 Figure on the right). These clusters were carried out based on the quantitative data of the fluorescence image analysis, using CellProfiler, using a set of 13 parameters to define the phenotypic profile of each treatment. In the heatmap, where bright blue represents the smallest value, bright yellow the largest and black the central value (PMC), the relative measures of the selected phenotypic traits are presented, resulting from the normalization of each treatment by the negative control (PMC) with the use Of KNIME tools. It should be noted that the same treatments performed on the two different plates were grouped according to the presented characteristics, thus demonstrating the robustness of the assay, as well as its capacity to identify changes in the morphology and expression of OCT4 and CCNB1 induced by treatments with molecules with action Similar on pluripotent cells.

Figure 02
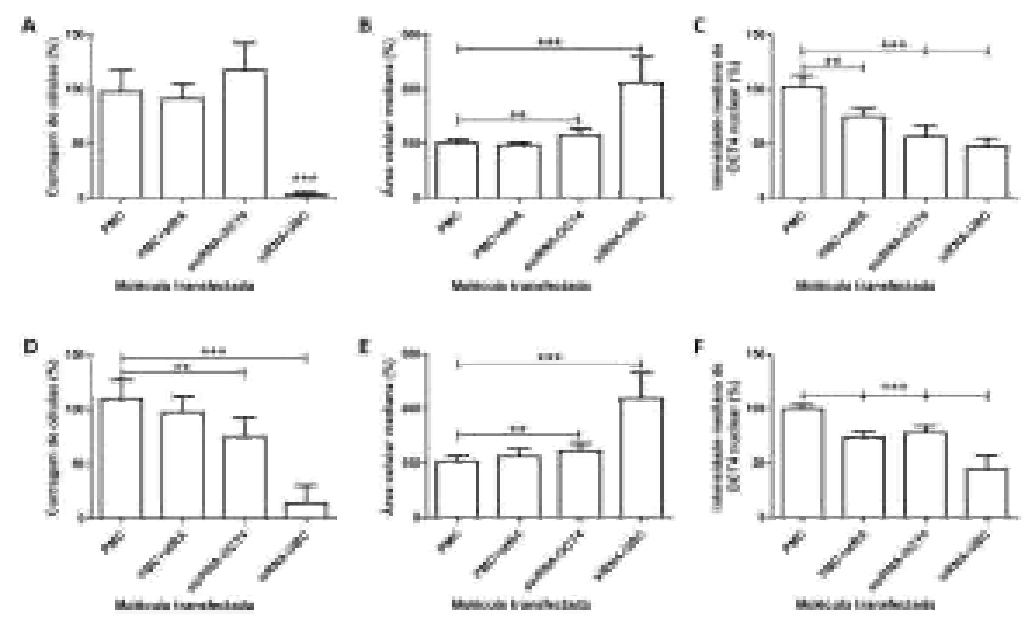

Figure 02 Results from the NTera-2 strain after treatment with: miR negative control (PMC), PMC followed by treatment with trans-retinoic acid, esiRNA-OCT4 and siRNA-UBC were presented from "A" to " $\mathrm{C}$ ". The results for the same treatments in line H1 are from "D" to "E". The transfection time for the NTera-2 strain was 4 days, the group receiving atRA was in contact with it for 3 days while for $\mathrm{H} 1$ the transfection time was 3 days and treatment with atRA was 2 days. A and D) transfection with siRNA-UBC led to a significant reduction in cell numbers for both the H1 and NTera-2 lines, whereas the esiRNA-OCT4 also reduced the number of $\mathrm{H} 1$ cells after incubation. B) Treatment with atRA did not significantly alter the area of the cells, whereas the esiRNA-OCT4 and siRNA-UBC led to a statistically significant increase in cell size for both $\mathrm{H} 1$ and NTera-2. C) In both cell lines, all treatments led to a significant reduction in nuclear OCT4 levels. $* *=\mathrm{P}<0.01, * * *$ $=\mathrm{P}<0.0001$ 
Figure 03

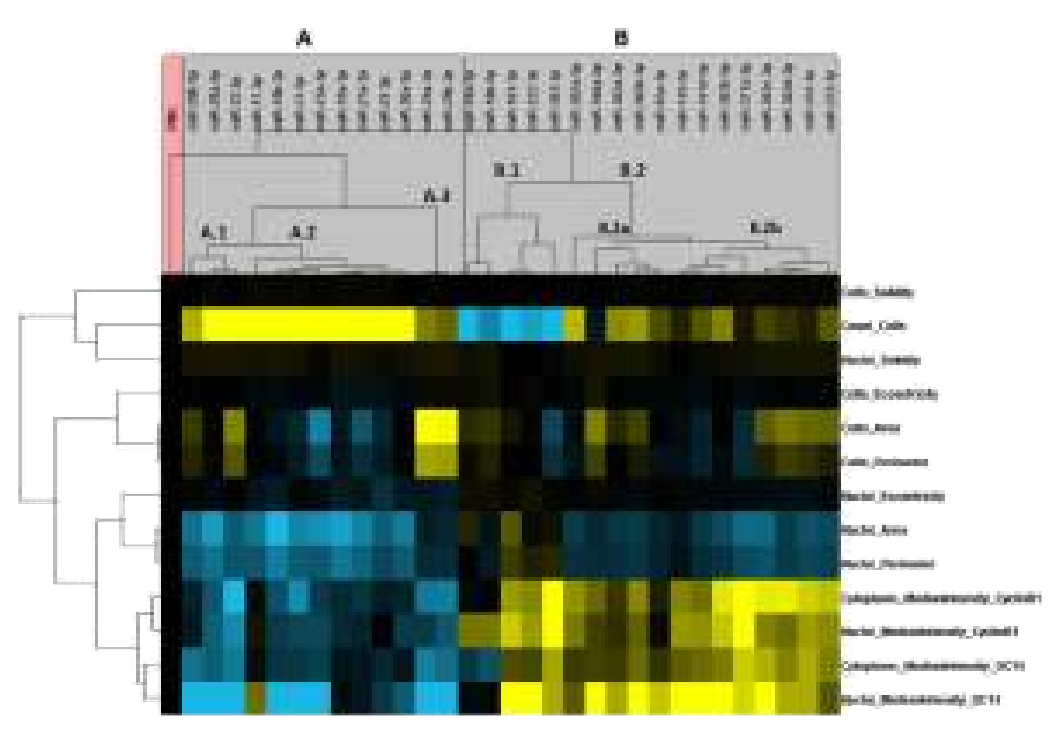

Figure 03. Clustering of the miRNAs for their phenotypic effects on the NTera-2 lineage, based on quantitative data from fluorescence image analysis by CellProfiler of cells transfected with miR mimics and negative control. In the heatmap, where bright blue represents a lower value, bright yellow represents a larger and black would be the central value, are presented the relative measures of the selected phenotypic traits, resulting from the normalization of each treatment by the negative control (PMC) with the use of tools Of KNIME. According to the profiles induced by each miRNA, two large clusters were identified, cluster A being formed by miRNAs that induced cell differentiation and cluster B by those that promoted pluripotency characteristics. These clusters were further subdivided according to the similarities and morphological differences observed in each treatment.

Figure 04

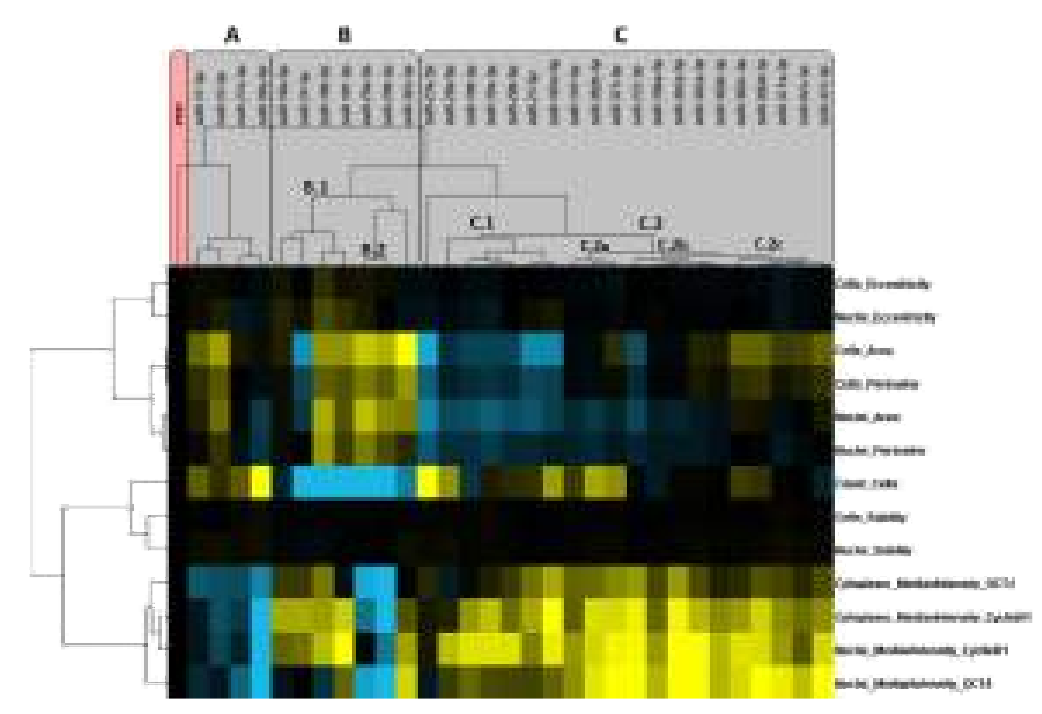

Figure 04. Clustering of the miRNAs for their phenotypic effects on the H1 lineage, based on the quantitative data generated from the fluorescence image analysis by CellProfiler of cells transfected with miR mimics and negative control (PMC). In the heatmap, where bright blue represents a lower value, bright yellow represents a larger and black would be the central value, are presented the relative measures of the selected phenotypic traits, resulting from the normalization of each treatment by the negative control with the use of KNIME tools. According to the profiles induced by each miRNA, three main clusters were identified, being the clusters A and B.2 formed by miRNAs that induced cell differentiation, and clusters B.1 and C, by those that promoted characteristics of pluripotency. The identified subclusters originated mainly due to the similarities and morphological differences observed in each treatment 
Figure 05
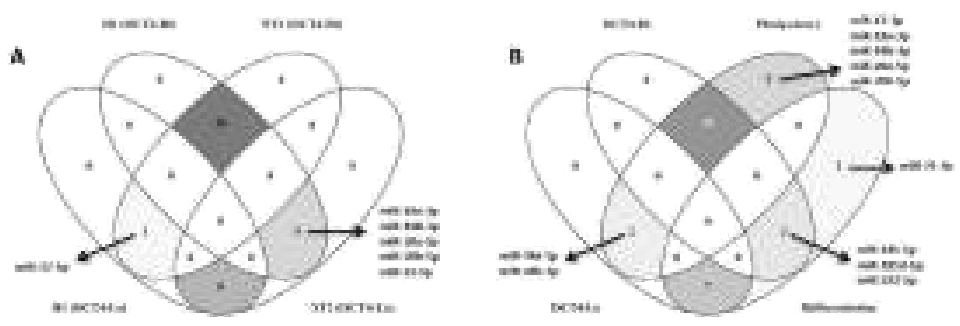

Figure 5. The Venn diagrams presented here represent the comparison of the functional assays in NTera-2 (NT2) and H1 (A), and between the results observed with the transfections and the expected, based on the scientific literature (B). To prepare the diagrams, the Venny 2.1 tool (http://bioinfogp.cnb.csic.es/tools/venny/) was used. Based on the medium nuclear fluorescence intensity for OCT4, the miRNAs were classified as pro- Pluripotency, inducing the increase of OCT4 (OCT4-Hi [High]), and cellular pro-differentiation (OCT4-Lo [Low]). Of the 31 miRNAs tested, 25 presented concordant results between the two human pluripotent cell lines, 16 of which were inducers of a pluripotent and 9 differentiation phenotype. B) The 25 miRNAs that showed concordant effects in NT2 and H1 had their functional activity compared to that expected. Of those with propluripotency activity (OCT4-Hi), 13 behaved congruently to the expected, and of the 9 with pro-differentiation effect, 7 were in agreement with the expected.

Figure 06
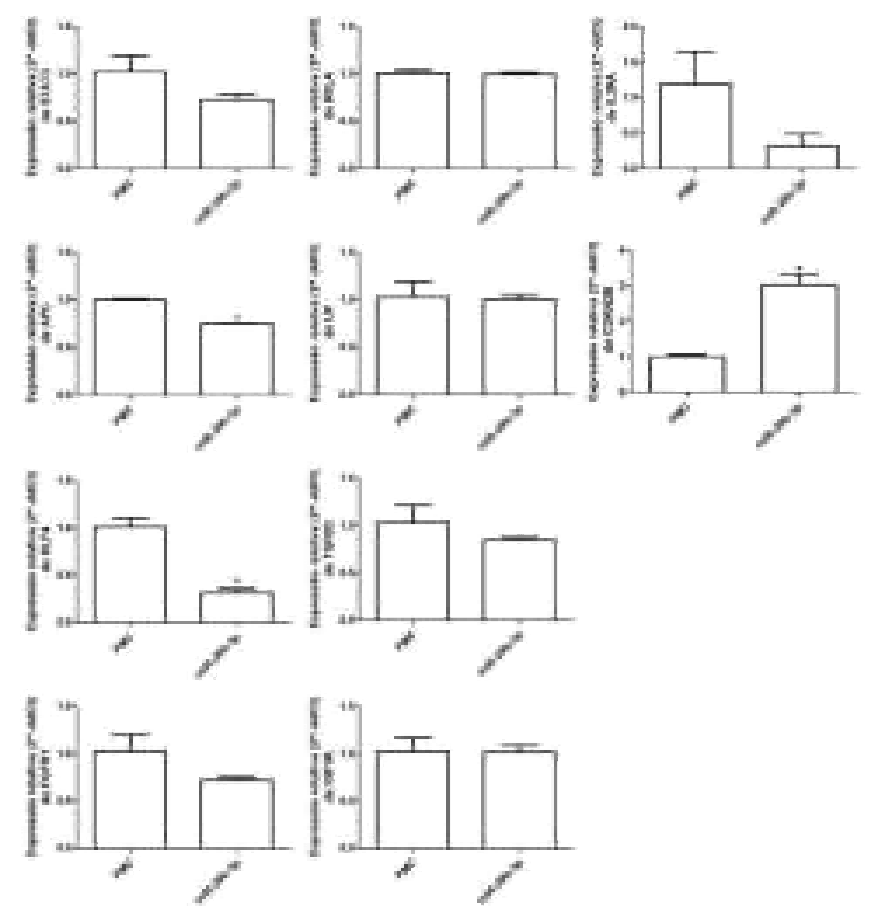

Figure 06. Relative quantification graphs $\left(2^{\wedge}\right.$-ddCt) for the STAT3, APC, KLF4, FGFR1, RELA, LIF, TGFB3, IGF1R, IL2RA and CDKN2B genes in NTera-2 cells transfected with miR-29b-3p by and incubated For $48 \mathrm{~h}$ under culture conditions, compared to cells transfected with the negative control (PMC). These analyzes demonstrated that the miRNA in question reduced transcriptional levels, statistically significant $(\mathrm{P}<0.05)$, for APC and KLF4, and led to an increase in the quantification of CDKN2B. $*=\mathrm{P}<0.05$. 
Figure 07
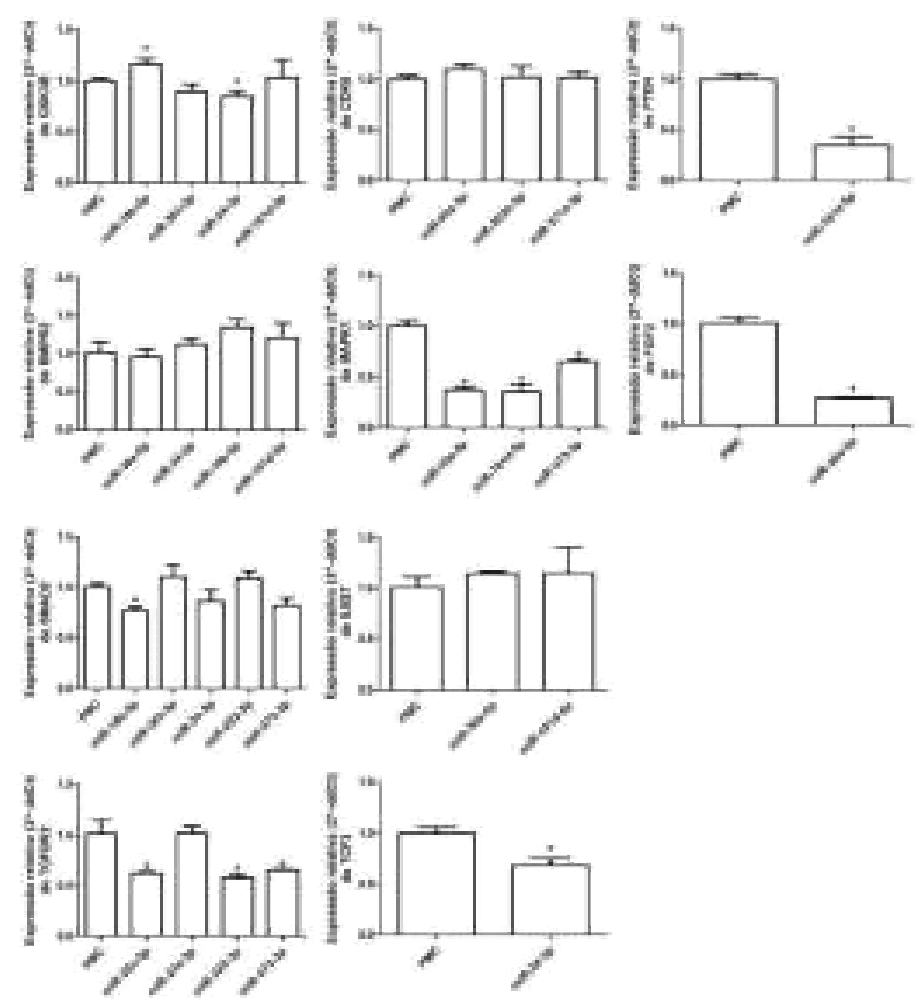

Figure 07. Relative quantification graphs $\left(2^{\wedge}-\mathrm{ddCt}\right)$ for the genes GSK3B, BMPR2, SMAD2, TGFBR2, CDK6, MAPK1, IL6ST, TCF3, PTEN and FGF2 in transfected NTera-2 cells miR mimics representative of the miRNAs of the phenotypic clusters (NTera-2 / H1), which are: miR-18b-5p (B.1 / B.1), miR-20a-5p (A1 / C1), miR-23a-3p (A.2 / C1), miR-24 (B.2a / C.2c), miR-181d-5p (B.2b / A), miR-30a-5p (A.2 / C.1), miR-222-3p (B.1 / C.2b), miR-302a-3p (B.2a / C.2b), miR-363-3p (B.1 / B.1), MiR-371a-3p (B.2b / C.2c), miR-373-3p (B.2b / C.2a). These cells were cultured for $48 \mathrm{~h}$ and had their total RNA extracted, from which the cDNA was made for qPCR quantification. Analyzes were relative to the group transfected with the negative control molecule (PMC). It is noteworthy that some miRNAs led to a reduction in the quantification of transcripts for the great majority of genes studied, a result that can validate the action of the miRNAs in the regulation of the pathways identified by the DAVID tool, from the identification of targets by an in silico approach . $*=\mathrm{P}<0.05$ 
Table 01

Table 01. Target genes from each subcluster separated according to the biological pathway detected by the DAVID tool. In the present case, the data of cluster A in the NTera-2 lineage are described.

\begin{tabular}{|c|c|c|}
\hline \multirow{6}{*}{ 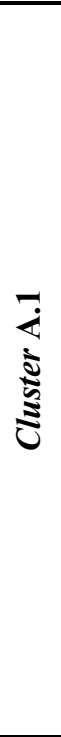 } & PI3K-AKT & $\begin{array}{l}\text { FGFR1, YWHAZ, PHLPP2, GRB2, FASLG, ITGA10, FGF12, PTEN, IGF1R, } \\
\text { EIF4EBP1, PDPK1, ITGB8, PPP2CA, ITGB6, PDGFC, AKT3, SYK, PPP2R1B, } \\
\text { PRKCA, COL4A4, CREB1, CREB5, ITGA3, IL6R, RPTOR, IFNAR1, PCK1, OSM, } \\
\text { MAPK1, NRAS, CDKN1A, HSP90B1, PRLR, IKBKG, MDM2, GNB4, LAMC1, } \\
\text { IKBKB }\end{array}$ \\
\hline & МАРК & $\begin{array}{l}\text { FGFR1, IL1R1, GRB2, MRAS, DUSP10, PPP3R1, MKNK2, MAP4K2, FASLG, } \\
\text { HSPA1B, FGF12, CACNB4, MAP3K7, MAP3K5, MAP3K3, MAP3K2, MAPT, FAS, } \\
\text { TRAF6, AKT3, RASA2, PRKCA, MAPK10, TAB1, STK4, PRKCB, RPS6KA,, } \\
\text { MAPK1, NRAS, DUSP3, RASGRF2, MAPK13, ARRB1, MAPK14, IKBKG, NTRK2, } \\
\text { CACNA1E, IKBKB, CACNA1D, MAP3K13, CRK, MAP3K12 }\end{array}$ \\
\hline & TNF & $\begin{array}{l}\text { TRAF1, CREB1, CREB5, MAPK10, CX3CL1, TAB1, MAP3K7, LIF, CASP10, } \\
\text { MAPK1, MAP3K5, TNFRSF1B, MAPK13, MAPK14, IKBKG, FAS, IKBKB, AKT3 }\end{array}$ \\
\hline & TGFß & $\begin{array}{l}\text { PPP2R1B, BMP2, RBL1, SMAD5, BMPR2, SMAD4, ACVR1B, MAPK1, ACVR2B, } \\
\text { EP300, ZFYVE16, PPP2CA, ZFYVE9, SMURF1 }\end{array}$ \\
\hline & WNT & $\begin{array}{l}\text { CSNK1A1, PRKCA, WNT5A, FZD8, TCF7, ROCK2, SMAD4, PPP3R1, MAPK10, } \\
\text { FZD5, PRKCB, FZD6, WNT2B, MAP3K7, DKK2, EP300, PSEN1, SFRP2, } \\
\text { CAMK2D, WNT9B, NFATC4, SOX17, TBL1X, FOSL1 }\end{array}$ \\
\hline & $\begin{array}{l}\text { Vias Regulando a } \\
\text { Pluripotência }\end{array}$ & $\begin{array}{l}\text { WNT5A, FGFR1, IL6ST, GRB2, BMPR2, PAX6, REST, LIF, PCGF5, IGF1R, } \\
\text { ACVR1B, SKIL, AKT3, FZD8, BMP2, ESRRB, SMAD5, SMAD4, FZD5, WNT2B, } \\
\text { FZD6, NRAS, MAPK1, ACVR2B, RIF1, MAPK13, MAPK14, WNT9B, KAT6A }\end{array}$ \\
\hline \multirow{2}{*}{ 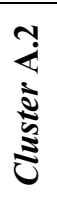 } & $\begin{array}{l}\text { Regulação do } \\
\text { Citoesqueleto de } \\
\text { Actina }\end{array}$ & MAPK1, ITGB8, ITGA1, ABI2 \\
\hline & mTOR & MAPK1, TSC1, RRAGD \\
\hline \multirow{8}{*}{ 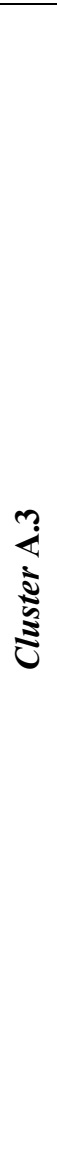 } & $\begin{array}{l}\text { Receptores de } \\
\quad \text { Matriz } \\
\text { Extracelular }\end{array}$ & $\begin{array}{l}\text { COL3A1, ITGA11, DAG1, COL2A1, ITGB1, COL6A6, GP1BB, COL27A1, } \\
\text { COL6A3, COL6A2, COL6A1, COL11A1, SV2C, COL4A3, COL4A2, COL4A1, } \\
\text { HSPG2, ITGA2, COL5A3, COL5A2, COL5A1, COL4A6, COL4A5, LAMA2, ITGA, } \\
\text { LAMC3, COL1A2, LAMC2, COL1A1, COL24A1 }\end{array}$ \\
\hline & Adesão Focal & $\begin{array}{l}\text { TLN1, PDGFB, TLN2, PDGFA, BCAR1, VCL, CDC42, ARHGAP5, PDGFD, SHC3, } \\
\text { COL11A1, AKT2, PIK3CG, PIK3CB, ACTN2, CRKL, RASGRF1, LAMC3, VEGFA, } \\
\text { COL1A2, PDGFRA, MAPK9, PDGFRB, LAMC2, MAPK8, COL1A1, COL24A1, } \\
\text { PARVA, CAV2, COL3A1, ITGA11, COL2A1, ITGB1, COL6A6, BCL2, COL27A,, } \\
\text { COL6A3, COL6A2, COL6A1, PIK3R5, PIK3R3, PIK3R1, COL4A3, COL4A2, } \\
\text { COL4A1, ITGA2, IGF1, COL5A3, BIRC3, BIRC2, COL5A2, COL4A6, COL5A1, } \\
\text { COL4A5, LAMA2, ITGA6, FYN, GSK3B, RAP1A }\end{array}$ \\
\hline & IGF-1 & PIK3CG, FOS, IGF1, MAPK8, IRS1, PIK3R1, RASA1 \\
\hline & mTOR & $\begin{array}{l}\text { PIK3CG, PIK3CB, STRADA, RPS6KB2, IGF1, RICTOR, IRS1, RRAGC, RPS6KA3, } \\
\text { RPS6KA1, ULK2, PIK3R5, PIK3R3, EIF4E2, PIK3R1, AKT2 }\end{array}$ \\
\hline & PI3K-AKT & $\begin{array}{l}\text { PDGFB, PDGFA, EFNA2, RPS6KB2, FOXO3, CCNE1, IL4R, GNG2, PDGFD, } \\
\text { GNG4, COL11A1, AKT2, PIK3CG, PPP2R1A, SGK1, PIK3CB, RELA, RXRA, IRS1, } \\
\text { CDK2, LAMC3, VEGFA, COL1A2, PDGFRA, PDGFRB, EFNA5, LAMC2, } \\
\text { COL1A1, COL24A1, FGFR3, MCL1, COL3A1, ITGA11, TCL1A, COL2A1, GNG1,, } \\
\text { ITGB1, G6PC3, COL6A6, BCL2, COL27A1, COL6A3, GYS1, COL6A2, COL6A1, } \\
\text { PIK3R5, PIK3R3, PPP2R2C, PIK3R1, COL4A3, COL4A2, IL2RA, COL4A1, ITGA,, } \\
\text { IGF1, COL5A3, YWHAE, COL5A2, COL4A6, COL5A1, COL4A5, LAMA2, GH2, } \\
\text { YWHAG, ITGA6, GSK3B, EPOR, EIF4E2 }\end{array}$ \\
\hline & TNF & $\begin{array}{l}\text { PIK3CG, IL18R1, PIK3CB, RELA, MAP2K4, BIRC3, BIRC2, CXCL10, TNFRSF1A, } \\
\text { FOS, CASP3, CASP7, CASP8, MAPK9, PIK3R5, MAPK8, TNFAIP3, PIK3R3, } \\
\text { TRAF5, PIK3R1, AKT2, TRAF3 }\end{array}$ \\
\hline & WNT & $\begin{array}{l}\text { NKD1, PPARD, WNT5B, NKD2, CAMK2G, DAAM1, DAAM2, GPC4, FRAT2, } \\
\text { NFATC3, WNT8B, APC, DVL3, TBL1XR1, WNT10B, VANGL1, FZD3, SKP1, } \\
\text { FZD4, CTNNBIP1, FZD10, WNT7B, GSK3B, LRP6, MAPK9, MAPK8 }\end{array}$ \\
\hline & $\begin{array}{l}\text { Vias Regulando a } \\
\text { Pluripotência }\end{array}$ & $\begin{array}{l}\text { FGFR3, WNT5B, PCGF3, HAND1, PIK3R5, PIK3R3, PIK3R1, APC, AKT2, } \\
\text { WNT8B, PIK3CG, SETDB1, DVL3, WNT10B, JARID2, PIK3CB, LIFR, IGF1, } \\
\text { FZD3, ISL1, FZD4, STAT3, ACVR2A, WNT7B, FZD10, ID1, GSK3B, ID3, ZFHX3, } \\
\text { KLF4, BMPR1A }\end{array}$ \\
\hline
\end{tabular}




\section{ANEXOS}

\section{Table 02}

Table 02. . Target genes from each subcluster separated according to the biological pathway detected by the DAVID tool. In the present case, the data of cluster B in the NTera-2 lineage are described.

\begin{tabular}{|c|c|c|}
\hline \multirow{2}{*}{ 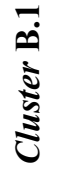 } & FOXO & CDKN2B, PIK3CA, BNIP3, SMAD2, AKT3, ATM \\
\hline & RAS & RASAL2, KSR2, GRIN2B, GAB1, PIK3CA, RAPGEF5, KIT, AKT3 \\
\hline \multirow{5}{*}{ 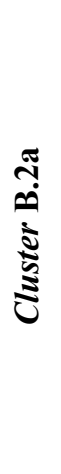 } & DICER & AGO2, AGO3, AGO4 \\
\hline & FOXO & $\begin{array}{l}\text { EGFR, G6PC, ATG12, SGK3, CCND2, PRKAB2, SETD7, PIK3CA, PRKAA2, } \\
\text { C8ORF44-SGK3, PTEN, BCL2L11 }\end{array}$ \\
\hline & mTOR & EIF4E, ULK1, PIK3CA, PRKAA2, RRAGD, PTEN, PRKCB \\
\hline & PI3K-AKT & $\begin{array}{l}\text { EGFR, YWHAZ, SGK3, CREB1, GNG11, TLR4, CDK6, C8ORF44-SGK3, PTEN, } \\
\text { BCL2L11, IFNAR2, G6PC, EIF4E, CHRM2, CCND2, TNR, ITGB6, PIK3CA, } \\
\text { PIK3AP1, PRKAA2, FGF2 }\end{array}$ \\
\hline & Toll-like Receptor & TIRAP, ELK1, TLR4, EIF2AK2, TRAF6, MAP2K6 \\
\hline \multirow{3}{*}{ 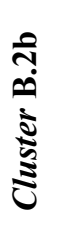 } & DICER & $\mathrm{AGO} 2, \mathrm{AGO} 3$ \\
\hline & VEGF & MAPK1, MAPK14, NFATC2 \\
\hline & $\begin{array}{l}\text { Vias Regulando a } \\
\text { Pluripotência }\end{array}$ & MAPK1, ACVR2B, MAPK14, ACVR1C \\
\hline
\end{tabular}


Table 03

Table 03. Here we present the target genes of each subcluster separated according to the biological pathway detected by the DAVID tool. In the present case, the data of clusters A and B in the line H1 are described.

\begin{tabular}{|c|c|c|}
\hline \multirow{3}{*}{$\frac{\square}{\vdots}$} & RAS & $\begin{array}{l}\text { MAPK1, PLA2G16, KSR2, GRIN2B, PIK3CD, GRIN2A, PLA2G2C, ABL1, KSR1, } \\
\text { ABL2 }\end{array}$ \\
\hline & $\begin{array}{l}\text { Regulação do } \\
\text { Citoesqueleto de } \\
\text { Actina }\end{array}$ & $\begin{array}{l}\text { MAPK1, CHRM3, ITGB8, ITGA5, PPP1R12B, PIK3CD, ABI2, ARHGEF12, } \\
\text { PIP4K2B }\end{array}$ \\
\hline & $\begin{array}{l}\text { Vias Regulando } \\
\text { a Pluripotência }\end{array}$ & MAPK1, ACVR2B, IL6ST, PIK3CD, BMPR2, SMAD4, WNT2B \\
\hline \multirow{3}{*}{$\begin{array}{l}-1 \\
\frac{1}{5} \\
\frac{5}{3}\end{array}$} & RAP1 & PARD6B, MAGI3, GRIN2B, MAPK13, RAP1A, PIK3CA, IGF1, CDH1 \\
\hline & mTOR & EIF4E, PIK3CA, IGF1, PRKAA1, RRAGD \\
\hline & $\begin{array}{l}\text { Vias Regulando } \\
\text { a Pluripotência }\end{array}$ & ONECUT1, MAPK13, GSK3B, BMPR2, PIK3CA, IGF1, SMAD2, FZD4 \\
\hline \multirow{5}{*}{ 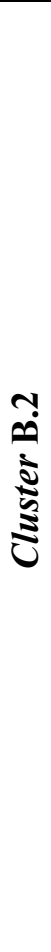 } & $\begin{array}{l}\text { Receptores de } \\
\text { Matriz } \\
\text { Extracelular }\end{array}$ & $\begin{array}{l}\text { COL3A1, ITGA11, DAG1, COL2A1, ITGB1, COL6A6, GP1BB, COL27A1, } \\
\text { COL6A3, COL6A2, COL6A1, COL11A1, THBS2, SV2C, COL4A3, COL4A2, } \\
\text { COL4A1, HSPG2, COL5A3, COL5A2, COL5A1, COL4A6, COL4A5, LAMA, } \\
\text { ITGA6, LAMC3, COL1A2, LAMC2, COL1A1, LAMC1, COL24A1 }\end{array}$ \\
\hline & Adesão Focal & $\begin{array}{l}\text { TLN1, PDGFB, PDGFA, BCAR1, VCL, CDC42, ARHGAP5, PDGFC, PDGFD, } \\
\text { SHC3, RAPGEF1, COL11A1, AKT2, PIK3CG, PIK3CB, ACTN2, CRKL, RASGRF1, } \\
\text { LAMC3, VEGFA, COL1A2, PDGFRA, MAPK9, PDGFRB, LAMC2, MAPK8, } \\
\text { COL1A1, LAMC1, COL24A1, COL3A1, ITGA11, COL2A1, ITGB1, COL6A6, } \\
\text { BCL2, COL27A1, COL6A3, COL6A2, COL6A1, PIK3R5, PIK3R3, THBS2, PIK3R1, } \\
\text { COL4A3, COL4A2, COL4A1, COL5A3, BIRC3, COL5A2, BIRC2, COL4A6, } \\
\text { COL5A1, COL4A5, LAMA2, ITGA6, FYN }\end{array}$ \\
\hline & PI3K-AKT & $\begin{array}{l}\text { PDGFB, PDGFA, EFNA2, RPS6KB2, CCNE1, IL4R, PDGFC, GNG2, PDGFD, } \\
\text { GNG4, COL11A1, AKT2, PIK3CG, PPP2R1A, SGK1, PIK3CB, RELA, RXRA, IRS1, } \\
\text { CDK2, LAMC3, VEGFA, COL1A2, PDGFRA, MDM2, PDGFRB, EFNA5, LAMC2, } \\
\text { LAMC1, COL1A1, COL24A1, FGFR1, FGFR3, PHLPP2, MCL1, COL3A1, ITGA1, } \\
\text { TCL1A, COL2A1, GNG12, ITGB1, G6PC3, COL6A6, PPP2CA, BCL2, COL27A1, } \\
\text { COL6A3, COL6A2, GYS1, COL6A1, PIK3R5, PIK3R3, PPP2R2C, THBS2, PIK3R1, } \\
\text { COL4A3, COL4A2, COL4A1, IL2RA, COL5A3, YWHAE, COL5A2, COL4A6, } \\
\text { COL5A1, COL4A5, LAMA2, GH2, NRAS, YWHAG, ITGA6, IKBKG, EPOR, } \\
\text { EIF4E2 }\end{array}$ \\
\hline & TNF & $\begin{array}{l}\text { PIK3CG, IL18R1, PIK3CB, RELA, MAP2K4, CX3CL1, BIRC3, TAB1, BIRC2, } \\
\text { CXCL10, LIF, TNFRSF1A, FOS, CASP3, CASP7, CASP8, IKBKG, MAPK9, } \\
\text { PIK3R5, MAPK8, TNFAIP3, PIK3R3, TRAF5, PIK3R1, AKT2 }\end{array}$ \\
\hline & $\begin{array}{l}\text { Vias Regulando } \\
\text { a Pluripotência }\end{array}$ & $\begin{array}{l}\text { FGFR1, FGFR3, WNT5B, LIF, PCGF3, HAND1, PIK3R5, PIK3R3, PIK3R1, APC, } \\
\text { AKT2, SETDB1, PIK3CG, DVL3, WNT10B, JARID2, PIK3CB, ISL1, NRAS, } \\
\text { ACVR2A, WNT7B, FZD10, ID1, ID3, ZFHX3, KLF4 }\end{array}$ \\
\hline
\end{tabular}




\section{ANEXOS}

Table 04

Table 04. Here we present the target genes of each subcluster separated according to the biological pathway detected by the DAVID tool. In the present case, the data of cluster C in lineage H1.

\begin{tabular}{|c|c|c|}
\hline \multirow{4}{*}{ 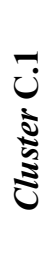 } & DICER & DICER1, AGO2, AGO4 \\
\hline & FOXO & MAPK1, TGFBR2, PRKAA2, MAPK10, PTEN, STK4, SOD2 \\
\hline & mTOR & MAPK1, PRKAA2, RRAGD, PTEN \\
\hline & $\begin{array}{l}\text { Vias Regulando a } \\
\text { Pluripotência }\end{array}$ & MAPK1, INHBA, IL6ST, GSK3B, BMPR2, LIFR, REST, WNT2B \\
\hline \multirow{6}{*}{ 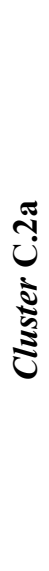 } & FOXO & $\begin{array}{l}\text { ATG12, TGFBR2, PRKAB2, SMAD3, SMAD2, IL7R, PTEN, SOD2, IGF1R, } \\
\text { MAPK1, G6PC, CSNK1E, CCND2, MAPK14, PIK3CA, SETD7, AKT3 }\end{array}$ \\
\hline & МАРК & $\begin{array}{l}\text { MEF2C, CACNA2D1, LAMTOR3, CACNG8, TAOK1, MAPKAPK5, TGFBR2, } \\
\text { MAP4K2, FGF10, ELK1, PRKCB, MAPK1, RPS6KA3, MAP3K2, ELK4, MAPK14, } \\
\text { FAS, PRKACB, RAPGEF2, TRAF6, MAP2K6, AKT3 }\end{array}$ \\
\hline & mTOR & MAPK1, RPS6KA3, EIF4E, ULK1, ULK3, PIK3CA, RRAGD, PTEN, AKT3, PRKCB \\
\hline & TGF $\beta$ & $\begin{array}{l}\text { INHBB, MAPK1, ACVR2B, GDF6, SMAD5, TGFBR2, RBL1, SMAD3, SMAD2, } \\
\text { THBS1, ACVR1C }\end{array}$ \\
\hline & Toll-like receptor & PPARA, MAPK14, TIRAP, ELK1, TLR4, EIF2AK2, TRAF6, MAP2K6 \\
\hline & $\begin{array}{l}\text { Vias Regulando a } \\
\text { Pluripotência }\end{array}$ & $\begin{array}{l}\text { ONECUT1, SMAD5, SMAD3, FZD3, SMAD2, REST, FZD5, FZD6, ACVR1C, } \\
\text { INHBB, IGF1R, MAPK1, ACVR2B, RIF1, MAPK14, PIK3CA, AKT3, WNT8B }\end{array}$ \\
\hline \multirow{9}{*}{ 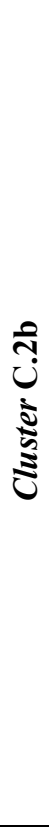 } & DICER & $\mathrm{AGO} 1, \mathrm{AGO} 2, \mathrm{AGO} 3, \mathrm{AGO} 4$ \\
\hline & EGF & EGFR, GRB2, PIK3CA, STAT3, PRKCB \\
\hline & FOXO & $\begin{array}{l}\text { EGFR, ATG12, GRB2, TGFBR2, PRKAB2, BCL2L11, STAT3, ATM, SOD2, } \\
\text { MAPK1, G6PC, CCND2, MAPK14, SETD7, PIK3CA, PRKAA2, AKT3 }\end{array}$ \\
\hline & JAK-STAT & IFNAR2, CCND2, GRB2, IFNE, PIK3CA, SOCS7, IL6R, SOCS5, AKT3, STAT3 \\
\hline & МАРК & $\begin{array}{l}\text { EGFR, GRB2, CACNG8, TAOK1, TGFBR2, PPP3R1, PRKCB, MAPK1, DUSP3, } \\
\text { MAP3K2, ELK4, MAPK14, CACNA1E, RAPGEF2, FGF2, MAP2K6, AKT3 }\end{array}$ \\
\hline & mTOR & MAPK1, EIF4E, PIK3CA, PRKAA2, AKT3, PRKCB \\
\hline & PI3K-AKT & $\begin{array}{l}\text { COL4A4, EGFR, GRB2, CREB1, LPAR3, GNG11, CDK6, IL6R, BCL2L11, IFNAR2, } \\
\text { MAPK1, G6PC, EIF4E, CHRM2, CCND2, PIK3CA, GNB4, PRKAA2, FGF2, AKT3, } \\
\text { SYK }\end{array}$ \\
\hline & RAS & $\begin{array}{l}\text { EGFR, PLA2G16, GRB2, GNG11, RGL1, PRKCB, RASAL2, MAPK1, PLCE1, } \\
\text { GRIN2B, PAK3, TIAM1, PLA2G12A, GAB1, RAPGEF5, PIK3CA, GNB4, FGF2, } \\
\text { AKT3 }\end{array}$ \\
\hline & $\begin{array}{l}\text { Vias Regulando a } \\
\text { Pluripotência }\end{array}$ & MAPK1, ACVR2B, RIF1, GRB2, MAPK14, SMAD5, PIK3CA, FGF2, AKT3, STAT3 \\
\hline \multirow{2}{*}{ 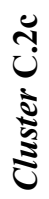 } & DICER & $\mathrm{AGO} 2, \mathrm{AGO} 3$ \\
\hline & FOXO & ATG12, SGK3, PIK3CA, FOXO3, C8ORF44-SGK3 \\
\hline
\end{tabular}


Table 05

Table 05. List of genes components of the Notch signaling pathway and the miRNAs that target them. This list was generated from the information contained in the Target Scan 7 database.

\begin{tabular}{|c|c|}
\hline $\begin{array}{l}\text { Notch pathway } \\
\text { component(gene) }\end{array}$ & miRNAs targetting gene component \\
\hline ADAM17 & $\begin{array}{l}\text { miR-101-3p, miR-145-5p, miR-181d-5p, miR-222-3p, miR-23a-3p, miR-24-3p, miR-302a-3p, } \\
\text { miR-302b-3p, miR-302c-3p, miR-302d-3p, miR-372-3p, miR-373-3p }\end{array}$ \\
\hline APH1A & $\begin{array}{l}\text { miR-145-5p, miR-24-3p, miR-302a-3p, miR-302b-3p, miR-302c-3p, miR-302d-3p, miR-372-3p, } \\
\text { miR-373-3p }\end{array}$ \\
\hline APH1B & $\begin{array}{l}\operatorname{miR}-101-3 p, \text { miR-145-5p, miR-17-3p, miR-181d-5p, miR-18a-5p, miR-18b-5p, miR-21-5p, miR- } \\
\text { 23a-3p, miR-24-3p, miR-302c-3p, miR-363-3p, miR-92a-3p }\end{array}$ \\
\hline CIR1 & miR-101-3p, miR-21-5p, miR-302a-5p \\
\hline CREBBP & $\begin{array}{l}\operatorname{miR}-106 a-5 p, \operatorname{miR}-20 a-5 p, \operatorname{miR}-20 b-5 p, \operatorname{miR}-23 a-3 p, \operatorname{miR}-24-3 p, \operatorname{miR}-302 a-3 p, \operatorname{miR}-302 a-5 p \\
\text { miR-302b-3p, miR-302b-5p, miR-302c-3p, miR-302d-3p, miR-372-3p, miR-373-3p }\end{array}$ \\
\hline CTBP1 & miR-101-3p, miR-17-3p, miR-302b-5p \\
\hline CTBP2 & miR-101-3p, miR-181d-5p, miR-18a-5p, miR-18b-5p, miR-23a-3p, miR-302a-5p, miR-302b-5p \\
\hline DLL1 & miR-24-3p, miR-371a-3p \\
\hline DLL4 & miR-101-3p, miR-302a-5p, miR-302c-3p, miR-363-3p, miR-92a-3p \\
\hline DTX1 & $\operatorname{miR}-145-5 p$ \\
\hline DTX2 & miR-363-3p, miR-92a-3p \\
\hline DTX3 & $\operatorname{miR}-24-3 p$ \\
\hline DTX3L & miR-101-3p, miR-17-3p, miR-21-5p, miR-222-3p, miR-24-3p, miR-302b-5p \\
\hline DTX4 & $\begin{array}{l}\text { miR-145-5p, miR-17-3p, miR-181d-5p, miR-24-3p, miR-302a-3p, miR-302b-3p, miR-302c-3p, } \\
\text { miR-302d-3p, miR-363-3p, miR-372-3p, miR-373-3p, miR-92a-3p }\end{array}$ \\
\hline DVL1 & miR-101-3p, miR-18a-5p, miR-18b-5p \\
\hline DVL2 & miR-222-3p, miR-23a-3p \\
\hline DVL3 & $\begin{array}{l}\text { miR-106a-5p, miR-18a-5p, miR-18b-5p, miR-20a-5p, miR-20b-5p, miR-21-5p, miR-24-3p, miR- } \\
\text { 302a-3p, miR-302b-3p, miR-302c-3p, miR-302d-3p, miR-372-3p, miR-373-3p }\end{array}$ \\
\hline EP300 & miR-106a-5p, miR-20a-5p, miR-20b-5p \\
\hline HDAC1 & $\operatorname{miR}-24-3 p$ \\
\hline HDAC2 & $\begin{array}{l}\text { miR-145-5p, miR-17-3p, miR-21-5p, miR-23a-3p, miR-24-3p, miR-302a-5p, miR-302b-5p, miR- } \\
\text { 363-3p, miR-92a-3p }\end{array}$ \\
\hline JAG1 & miR-17-3p, miR-21-5p, miR-23a-3p, miR-302b-5p \\
\hline JAG2 & miR-145-5p, miR-19a-3p, miR-19b-3p, miR-24-3p, miR-302c-3p \\
\hline КАТ2B & $\begin{array}{l}\operatorname{miR}-106 a-5 p, \operatorname{miR}-181 d-5 p, \operatorname{miR}-19 a-3 p, \operatorname{miR}-19 b-3 p, \operatorname{miR}-20 a-5 p, \operatorname{miR}-20 b-5 p, \operatorname{miR}-23 a-3 p \\
\text { miR-302a-3p, miR-302b-3p, miR-302c-3p, miR-302d-3p, miR-363-3p, miR-372-3p, miR-373-3p, } \\
\text { miR-92a-3p }\end{array}$ \\
\hline LFNG & $\operatorname{miR}-24-3 p$ \\
\hline MAML1 & $\begin{array}{l}\operatorname{miR}-145-5 p, \operatorname{miR}-17-3 p, \operatorname{miR}-19 a-3 p, \operatorname{miR}-19 b-3 p, \operatorname{miR}-222-3 p, \operatorname{miR}-23 a-3 p, \operatorname{miR}-24-3 p, \text { miR- } \\
\text { 302a-3p, miR-302b-3p, miR-302b-5p, miR-302c-3p, miR-302d-3p, miR-372-3p, miR-373-3p }\end{array}$ \\
\hline MAML2 & $\begin{array}{l}\text { miR-101-3p, miR-17-3p, miR-23a-3p, miR-302a-3p, miR-302a-5p, miR-302b-3p, miR-302b-5p, } \\
\text { miR-302c-3p, miR-302d-3p, miR-363-3p, miR-372-3p, miR-373-3p, miR-92a-3p }\end{array}$ \\
\hline MAML3 & $\begin{array}{l}\operatorname{miR}-101-3 p, \operatorname{miR}-145-5 p, \operatorname{miR}-17-3 p, \operatorname{miR}-18 a-5 p, \operatorname{miR}-18 b-5 p, \text { miR-19a-3p, miR-19b-3p, miR- } \\
\text { 24-3p, miR-302a-5p, miR-302b-5p, miR-363-3p, miR-92a-3p }\end{array}$ \\
\hline MFNG & $\operatorname{miR}-302 a-5 p$ \\
\hline NCSTN & $\operatorname{miR}-145-5 p, \operatorname{miR}-24-3 p$ \\
\hline NOTCH1 & miR-101-3p, miR-363-3p, miR-92a-3p \\
\hline NOTCH2 & $\begin{array}{l}\operatorname{miR}-101-3 p, \operatorname{miR}-181 d-5 p, \operatorname{miR}-18 a-5 p, \operatorname{miR}-18 b-5 p, \operatorname{miR}-19 a-3 p, \operatorname{miR}-19 b-3 p, \operatorname{miR}-23 a-3 p \\
\text { miR-302a-3p, miR-302a-5p, miR-302b-3p, miR-302c-3p, miR-302d-3p, miR-363-3p, miR-372-3p, } \\
\text { miR-373-3p, miR-92a-3p }\end{array}$ \\
\hline NOTCH3 & $\operatorname{miR}-24-3 p$ \\
\hline
\end{tabular}




\section{ANEXOS}

\begin{tabular}{cl}
\hline NOTCH4 & miR-181d-5p, miR-302a-5p \\
NUMB & miR-101-3p, miR-17-3p \\
NUMBL & $\begin{array}{l}\text { miR-106a-5p, miR-20a-5p, miR-20b-5p, miR-302a-3p, miR-302b-3p, miR-302c-3p, miR-302d-3p, } \\
\text { miR-372-3p, miR-373-3p } \\
\text { miR-101-3p, miR-106a-5p, miR-145-5p, miR-17-3p, miR-181d-5p, miR-18a-5p, miR-18b-5p, } \\
\text { miR-20a-5p, miR-20b-5p, miR-222-3p, miR-24-3p, miR-302a-3p, miR-302b-3p, miR-302b-5p, } \\
\text { miR-302c-3p, miR-302d-3p, miR-363-3p, miR-372-3p, miR-373-3p, miR-92a-3p }\end{array}$ \\
PSEN2 & miR-302a-5p \\
RBPJ & $\begin{array}{l}\text { miR-101-3p, miR-181d-5p, miR-18a-5p, miR-18b-5p, miR-21-5p, miR-302a-5p, miR-302b-5p, } \\
\text { miR-302c-3p, miR-363-3p, miR-92a-3p }\end{array}$ \\
RBPJL & miR-17-3p \\
RFNG & $\begin{array}{l}\text { miR-17-3p, miR-302a-3p, miR-302a-5p, miR-302b-3p, miR-302c-3p, miR-302d-3p, miR-372-3p, } \\
\text { miR-373-3p }\end{array}$ \\
SNW1 & miR-145-5p, miR-302b-5p, miR-302c-3p \\
\hline
\end{tabular}

